\title{
MEIRE FESTA
}

\section{A (DES) construção de um espaço e (RE) construção de uma prática educativa: a jornada de uma professora de educação infantil num espaço reorganizado}

Dissertação apresentada à Faculdade de Educação da Universidade de São Paulo para obtenção do título de Mestre em Educação.

Área de Concentração: Metodologia e Didática Orientadora: Profa. Dra. Mônica Appezzato Pinazza

São Paulo

2008 
Autorizo a reprodução e divulgação total ou parcial deste trabalho, por qualquer meio convencional ou eletrônico, para fins de estudo e pesquisa, desde que citada a fonte.

Catalogação na Publicação

Serviço de Biblioteca e Documentação

Faculdade de Educação da Universidade de São Paulo

372.21(81.61) Festa, Meire

F418d $\quad A$ (des) construção de um espaço e (re) construção de uma prática educativa : a jornada de uma professora de educação infantil num espaço reorganizado / Meire Festa ; orientação Mônica Appezzato Pinazza São Paulo : s.n., 2008.

208 p. il., grafs, quadros.

Dissertação (Mestrado - Programa de Pós-Graduação em Educação.Área de Concentração : Metodologia e Didática) - Faculdade de Educação da Universidade de São Paulo.

1. Educação infantil - São Paulo, SP 2. Formação continuada de professores 3. Prática de ensino 4. Escola pública 5. Espaço escolar - Organização I. Pinazza, Mônica Appezzato, orient. 


\section{FOLHA DE APROVAÇÃO}

\section{Meire Festa}

A (DES) construção de um espaço e (RE) construção de uma prática educativa: a jornada de uma professora de educação infantil num espaço reorganizado

Dissertação apresentada à Faculdade de Educação da Universidade de São Paulo para obtenção do título de Mestre em Educação. Área de Concentração: Metodologia e Didática

\section{BANCA EXAMINADORA}

Profa. Dra. Tizuko Morchida Kishimoto (Universidade de São Paulo)

Profa. Dra. Maria Malta Campos

(Pontifícia Universidade Católica de São Paulo)

Profa. Dra. Mônica Appezzato Pinazza

(Universidade de São Paulo - orientadora)

Aprovada em / / 
A Maria, Valdomiro, Paulo, Marta, Fernanda e Renata, com amor e gratidão pelo afeto desmedido que sempre me ofereceram e pelo apoio incansável demonstrado antes e durante o enfrentamento deste e de muitos outros desafios colocados em minha vida. 


\section{AGRADECIMENTOS}

Ao término deste trabalho não consigo esquecer de tantas mãos amigas que, além das minhas, ajudaram a escrever essa história. Mãos que acolheram, afagaram, abraçaram, aplaudiram, questionaram, trabalharam junto e até empurraram ou sacudiram nos momentos necessários. Todas, a seu modo, tornaram-se inesquecíveis e terão sempre minha sincera gratidão.

A Profa. Mônica que desde o primeiro momento acolheu meus não-saberes auxiliou-me na construção de saberes novos e, através de seu exemplo, esforço, competência e dedicação, estimulou-me a empreender esta tarefa que se mostrou muito gratificante.

A Profa. Tizuko que partilhou comigo sua sabedoria e experiência, trazendo incontáveis contribuições para minha formação, prática educativa e de pesquisadora.

A Profa. Maria Malta que se predispôs a contribuir com minha formação enquanto pesquisadora, fazendo uma análise do percurso desenvolvido neste estudo.

A Profa. Julia que trouxe grandes e generosas colaborações a esse trabalho por ocasião do processo de qualificação.

A Profa. Luciana, minha amiga e parceira nesse desafio, pela sua paixão de ensinar e aprender e pela oportunidade que me ofereceu de participar de sua prática pedagógica junto à criança pequena, quando aprendi muito, sob diferentes aspectos.

A Marta e Fátima que nos idos de 2000/ 2004, na gestão da unidade escolar, me apoiaram nos processos de inovação da prática pedagógica, apoio esse que veio culminar nesse estudo.

A Roselene e Vera, grandes amigas e pares (muito) avançados, pela generosidade com que me acolheram, pelo afeto demonstrado e pelo muito que têm-me ensinado.

A todas minhas amigas do grupo de Contextos Integrados de Educação Infantil, pelo grande apoio demonstrado durante essa jornada de descobertas de uma nova pesquisadora.

Por último, e principalmente, a Deus e aos amigos (daqui e de lá) que sempre colocaram em meu caminho pessoas e acontecimentos maravilhosos. 
Talvez, para além do aparente ou para além do discurso esperado, a transformação signifique encontrar-se no chão, amparada, mas estando ali simultaneamente, em movimento intenso. Manter-se na roda, sem tirar o chão do outro, sem perder seu próprio chão, sendo puxada, incentivada, acionada, para cima, continuando no lugar, vibrando, mantendo-se em mudança, embora imperceptível, sem estardalhaço, sem holofote nem espetáculo. Parece ser essa a mudança de que precisamos.

KRAMER,S. (2004 p.512) 


\section{RESUMO}

Festa, M. A (DES) construção de um espaço e (RE) construção de uma prática educativa: a jornada de uma professora de educação infantil num espaço reorganizado. 2008. 208 f. Dissertação (Mestrado) - Faculdade de Educação, Universidade de São Paulo, São Paulo, 2008.

O objetivo deste trabalho foi acompanhar a ação de uma educadora de infância num espaço reorganizado, verificando as alterações que realizou nesse espaço e em sua prática educativa no decorrer do processo de pesquisa-ação, observando ainda os efeitos dessas alterações nas crianças através do envolvimento nas atividades que realizavam. A pesquisa desenvolveu-se numa Escola Municipal de Educação Infantil (EMEI) que desenvolvia a proposta pedagógica de Reorganização dos Espaços e das Atividades. A escolha justifica-se por três fatores interligados: necessidade de investigação sobre a formação profissional dos educadores de infância; importância de buscar possibilidades de apoio a práticas educativas que se desvinculem de propostas escolarizantes; fragilidade dos processos de formação em serviço desenvolvidos pelos sistemas educacionais na cidade de São Paulo. O trabalho caracteriza-se como um estudo de caso único, na perspectiva da pesquisa-ação e da tutoria entre pares. Foi realizado o acompanhamento da prática pedagógica através de dois eixos complementares: um voltado ao processo formativo da educadora e o segundo relacionado aos efeitos desse processo na prática pedagógica e no envolvimento das crianças na atividade, com base no instrumento criado por Ferre Laevers - "Escala de Envolvimento da Criança" (The Leuven Involvement Scale for Young Children - LIS-YC). Os instrumentos utilizados foram a observação participante, entrevistas semi-estruturadas, gravação e transcrição de áudio, registro e análise de imagens, documentos escritos. A avaliação dos resultados apontou que o processo formativo gerou mudanças efetivas na prática desenvolvida pela educadora, que foi capaz de responsabilizar-se pelos efeitos de sua prática nas ações das crianças, criando uma postura diferenciada da inicial como investigadora de sua própria prática, identificando problemas na ação, criando hipóteses sobre possíveis causas e buscando maneiras de transformar o que observava. Concluiu-se, com o processo de pesquisa-ação / tutoria entre pares, que a educadora pôde distanciar-se de uma pedagogia transmissiva, aproximando-se de uma pedagogia da participação, que valoriza a ação e o protagonismo da criança, ao mesmo tempo em que deixa para a educadora o real papel de mediadora do processo de construção de conhecimento da criança pequena.

Palavras-chave: educação infantil, formação de educadores, estudo de caso, tutoria entre pares, reorganização dos espaços, EMEI. 


\title{
ABSTRACT
}

\author{
FESTA, M. THE (DE)CONSTRUCTION OF A SPACE AND THE \\ (RE)CONSTRUCTION OF AN EDUCATIONAL PRACTICE: THE JOURNEY OF A \\ CHILDREN'S EDUCATOR IN A REORGANIZED SPACE. 2008. 208 P. MASTER'S \\ DISSERTATION - SCHOOL OF EDUCATION, UNIVERSITY OF SÃO PAULO, \\ SÃO PAULO, 2008.
}

The purpose of this work was to follow the actions of a children's educator in a reorganized space, and to determine the changes created by this educator in that space, as well as in her educational practice during this collaborative research-action process. The effects of such changes on the children through their involvement in the activities were also taken into consideration. The research was conducted in a children's public school (EMEI) where the Reorganization of Spaces and Activities teaching proposal was developed. This choice was made based on three associated factors: the need to investigate the professional training of children's educators; the importance of finding potential support for educational practices different from conventional ones; and the weakness of the educational processes currently developed by the educational system in the city of São Paulo. This work is a single case study from the perspective of a collaborative research-action and peer tutoring. The teaching practice was investigated based on two complementary axes: one was aimed at the training process of the educator and the other was related to the effects of such process on both the teaching practice and the children's involvement in the activities, all according to the tools created by Ferre Laevers - "The Leuven Involvement Scale for Young Children - LIS-YC". The tools in hand included participant observation, semi--structured interviews, audio recording and transcript, image recording and analysis, in addition to written documents. The assessment of results showed that the training process brought forth certain effective changes into the practice introduced by the educator, who was then able to hold herself responsible for the effects of her practices on the children's actions. Through this process, the educator created a different stance as an investigator of her own practices, which enabled her to identify certain issues in the actions, develop hypotheses regarding potential causes, and seek ways to transform what was then observed. The conclusion is that the collaborative research-action and peer tutoring process enabled the educator to get rid of a transmissive teaching approach and become closer to a more participant teaching, thus promoting actions and children's leadership while assigning the educator the true role of a mediator in the process of building up children's early knowledge.

Key Words: children's education, educator training, case study, peer tutoring, reorganization of spaces, EMEI. 


\section{LISTA DE ILUSTRAÇÕES}

Figura 1- Configuração da sala , anterior a reorganização dos espaços............... 45

Figura 2 - Sala reorganizada - visão geral................................................... 46

Figura 3 - Sala reorganizada - baldes com brinquedos........................................46

Figura 4 - Croqui da EMEI Eurípedes Simões de Paula........................................93

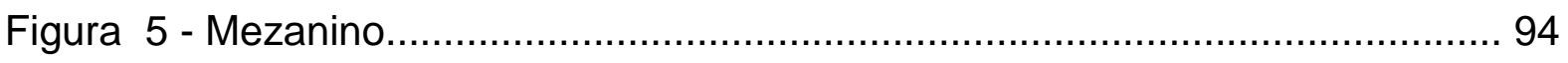

Figura 6 - Processo de Tutoria entre Pares................................................... 116

Figura 7- Pintura livre: menina KA.......................................................... 117

Figura 8 - Pintura livre: menina GAB-C (1) ............................................ 117

Figura 9 - Pintura livre: menino $\mathrm{JH}$................................................................ 117

Figura 10 - Pintura livre: menina GAB C (2)....................................................117

Figura 11- Utilização da técnica ensina pela educadora: desenho com o

cabo do pincel................................................................................. 120

Figura 12 - Uso da cor e do espaço na pintura livre............................................120

Figura 13 - Pintura livre após observação de diferentes obras de arte....................120

Figura 14 - Pintura livre da menina GAB-C durante o processo...........................120

Figura 15 - Pintura livre da menina GAB-C durante o processo.............................120

Figura 16 - Pintura livre com detalhamento, variação de técnicas e uso pre-

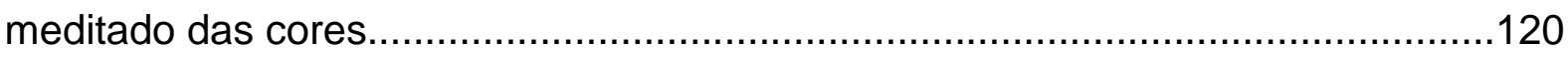

Figura 17 - Entrada da sala e parede da lousa................................................123

Figura 18 - Caixas de brinquedo e mesas para jogos........................................123

Figura 19 - Painel de cortiça e computador de uso das crianças............................124

Figura 20 - Computador e vista parcial das mesas............................................124

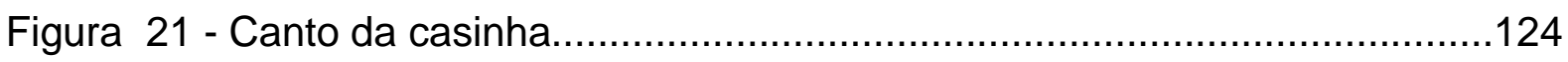

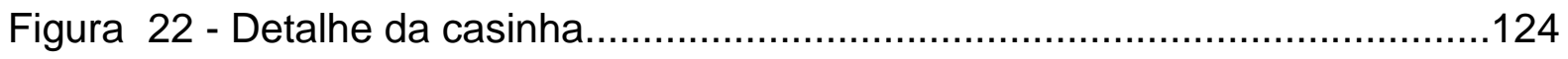

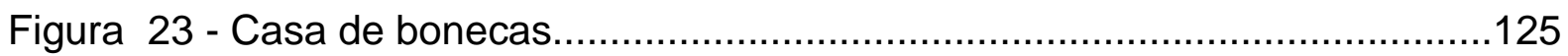

Figura 24 - Penteadeira e utensílios do consultório médico.................................125

Figura 25 - Prateleira com jogos e caixa de carrinhos..........................................125

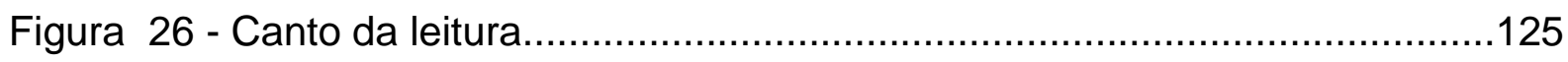

Figura 27 - Mesa de atividades artísticas e pia.................................................125

Figura 28 - Armários com materiais acessados pelas crianças, mesas e pia. 


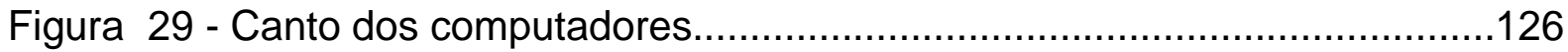

Figura 30 - Vão livre, armários e mesas.....................................................126

Figura 31 - Crianças brincando com quebra-cabeças gigante comprado pela

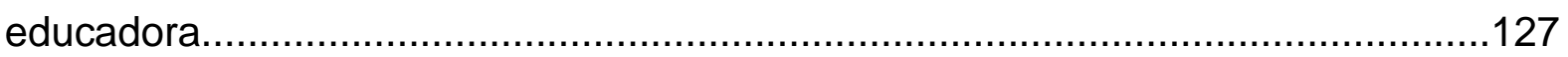

Figura 32 - Crianças brincando com massa de modelar caseira. ........................127

Figura 33 - Crianças brincando com jogo da memória do acervo da educadora

Figura 34 - Crianças brincando com quebra-cabeças do acervo da educadora

Figura 35 - Atividades realizadas com diferentes materiais para colagem (1).......127

Figura 36 - Atividades realizadas com diferentes materiais para colagem (2).......127

Figura 37 - Crianças pintando com tinta feita com detergente e anilina.............. 128

Figura 38 - Desenho complementado com fita adesiva colorida............................128

Figura 39 - Desenho dirigido - música da casa..............................................129

Figura 40 - Desenho dirigido - o carnaval...................................................129

Figura 41 - Atividade de contagem e escrita de numerais....................................130

Figura 42 - Atividade para ligar a palavra ao desenho correspondente..................130

Figura 43 - Menino desenha com cola sobre o desenho feito com canetinha........130

Figura 44 - Pintura em grupo.................................................................130

Figura 45 - Atividade orientada: educadora ensina jogo cooperativo produzido por ela.

Figura 46 - Crianças jogam espontaneamente, utilizando jogo produzido pela educadora.

Figura 47 - Crianças jogam espontaneamente, utilizando jogo produzido pela educadora que envolve contagem e raciocínio lógico.

Figura 48 - estrela desenhada, recortada, pintada com tinta e colagem de diferentes materiais

Figura 49 - Estrelas produzidas utilizando diferentes técnicas

Figura 50 - Árvore de natal confeccionada a partir de recorte do contorno das mãos das próprias crianças. 138

Figura 51 - Montagem da casinha. 162

Figura 52 - Montagem da floresta com a casa dos bichos 162 


\section{LISTA DE GRÁFICOS}

Gráfico 1- Envolvimento da criança na brincadeira - escores médios. 148

Gráfico 2 - Envolvimento da criança na brincadeira - médias mensais anuais.

Gráfico 3 - Escore médio de envolvimento nas atividades propostas pelas educadoras

Gráfico 4 - Envolvimento nas atividades propostas pela educadora- médias de Agosto a Novembro

Gráfico 5 - Médias do mês de Novembro- brincadeira e atividades orientadas.

Gráfico 6 - Envolvimento na brincadeira - média de setembro e novembro 156

Gráfico 7 - Envolvimento nas atividades orientadas - média de Setembro e Novembro

Gráfico 8 - Comparativo da média de envolvimento na brincadeira. 156

Gráfico 9 - Escore de envolvimento no uso do computador. 157

Gráfico 10 - Média de envolvimento no uso do computador. 158

Gráfico 11 - Comparativo anual de envolvimento por tipo de atividade 158

Gráfico 12 - Escore médio do envolvimento na roda de conversa. 160

Gráfico 13 - Envolvimento nas atividades orientadas e na roda de conversa comparativo do mês de Novembro 


\section{LISTA DE QUADROS}

Quadro 1- Unidades de Educação Infantil da PMSP........................................... 90

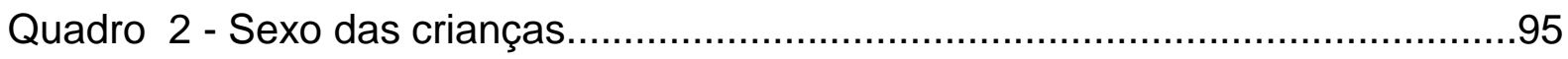

Quadro 3 - Idade e escolaridade anterior das crianças....................................... 95

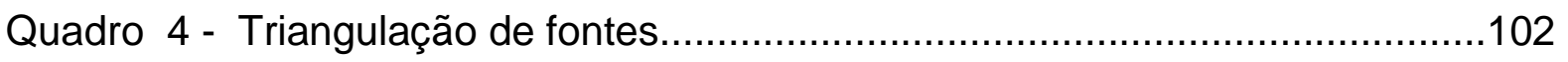

Quadro 5 - Entrevistas com a educadora.....................................................111

Quadro 6 - Cronograma de observações.......................................................113

Quadro 7 - Cronograma das reuniões de tutoria..............................................115

Quadro 8 - Intervenções da educadora na atividade de pintura livre....................119

Quadro 9 - Cronograma dos auto-relatos da educadora.....................................122

Quadro 10 - Escala de Envolvimento da Criança- níveis de envolvimento............143

Quadro 11 - Cronograma de coleta de dados do envolvimento das crianças.........144

Quadro 12 -Envolvimento das crianças na brincadeira- médias mensais Individuais 


\section{LISTA DE ANEXOS}

Anexo A - Transcrição da entrevista de 12/02/06 ……......................................182

Anexo B - Análise de conteúdo da entrevista de 12/02/06 .....................................189

Anexo C - Ficha de observação do envolvimento da criança ................................191

Anexo D - Transcrição da entrevista de 20/ 12/06 ….......................................193

Anexo E - Auto- relatos da educadora Luciana (excertos) ..............................207 


\section{SUMÁRIO}

RESUMO

ABSTRACT

LISTA DE ILUSTRAÇÕES

LISTA DE GRÁFICOS

LISTA DE QUADROS

LISTA DE ANEXOS

INTRODUÇÃO

\section{PARTE I - FUNDAMENTAÇÃO TEÓRICA}

1- REFERENCIAIS PEDAGÓGICOS À PRÁTICA DA EDUCAÇÃO INFANTIL 23

1.1 Breve histórico do atendimento à infância 24

1.2 Panorama histórico da Educação Infantil no Brasil e em São Paulo 29

1.3 Modelo Pedagógico High Scope $\quad 35$

1.4 Modelo Pedagógico de Reggio Emilia 38

1.5 Contextualização dos modelos pedagógicos na educação da infância no Município de São Paulo

1.6 Proposta curricular da unidade em estudo: Reorganização dos Espaços e das Atividades

1.6.1 Fase I: implantação da proposta $\quad 43$

1.6.2 Fase II: de 2004 à época da pesquisa 48

2- O BRINCAR NA EDUCAÇÃO DA CRIANÇA PEQUENA 52

2.1 Trajetória evolutiva do jogo 53

2.2 Conceito de jogo e brincadeira 56 
2.3 Teorizações da Psicologia socioconstrutivista sobre a brincadeira

2.4 A brincadeira no Modelo Pedagógico High Scope

2.5 A brincadeira no Modelo Pedagógico de Reggio Emília

2.6 A brincadeira na educação pública de São Paulo

2.7 A brincadeira na proposta de Reorganização dos Espaços e das Atividades

3- CONSIDERAÇÕES SOBRE A QUALIDADE NA EDUCAÇÃO INFANTIL: um olhar possível

3.1 Formação como promotora de qualidade

3.2 Fluxo e Envolvimento enquanto indicadores da qualidade do contexto educativo

PARTE II - ESTUDO EMPÍRICO

4 - METODOLOGIA DA INVESTIGAÇÃO

4.1 Contexto da Investigação

5.2 EIXO II - Prática Pedagógica: estudo sobre o envolvimento das crianças nas atividades

5.2.2 A brincadeira espontânea e o envolvimento da criança: registros das observações 
5.2.2 A atividade proposta pela educadora e o envolvimento da criança: registros de observações

5.2.3 Uso do computador

CONSIDERAÇÕES FINAIS

\section{REFERÊNCIAS}

ANEXOS 


\section{INTRODUÇÃO}

O trabalho insere-se no plano da formação continuada em serviço de uma educadora da Rede Municipal de Educação da cidade de São Paulo, que se propõe a alterar sua prática a partir da reflexão sobre ações desenvolvidas junto ao seu agrupamento de crianças do $3^{\circ}$ estágio da educação infantil.

Cada vez mais no campo da educação tem-se clareza da impossibilidade de atingir patamares de qualidade progressivamente mais elevados sem pensar maneiras de envolver os educadores em processos reflexivos que os confrontem com suas práticas educativas. Não há qualidade no vácuo, a qualidade se constrói pela ação, na ação e agregando saberes que auxiliem o processo reflexivo sobre essa ação.

A escolha da temática de trabalho foi motivada por quatro importantes fatores:

Em primeiro lugar, vale dizer que a escola pública do Município de São Paulo concentrava, em 2006, ano de realização deste estudo, 67\% das matrículas efetivadas na educação infantil ${ }^{1}$. Considera-se que este dado já seria motivo suficiente para se pensarem maneiras de otimizar a formação continuada dos educadores de infância, com estudos que auxiliassem a busca de opções para a efetivação deste processo formativo.

Um segundo aspecto é que, acompanhando o trabalho nas unidades educacionais da Rede Municipal de Educação, nota-se que a realidade das Escolas Municipais de Educação Infantil (EMEls) demonstra características muito diversas de região para outra e, por vezes, dentro da mesma região. Essa diversidade de práticas efetivadas decorre de concepções díspares, nem sempre conscientes ou explícitas, sobre aprendizagem, desenvolvimento, ensino e o papel do educador de infância no processo educativo.

Em pesquisa recente sobre a qualidade da educação infantil brasileira, Campos (2006) ressalta que vários estudos apontam para o descompasso entre as concepções defendidas pelos documentos oficiais de orientação curricular, o discurso da equipe de supervisão, o planejamento das unidades, quando existe, e as práticas observadas no cotidiano.

\footnotetext{
${ }^{1}$ Dados do Instituto Nacional de Estudos e Pesquisas Educacionais Anísio Teixeira (INEP), vinculado ao Ministério da Educação e Cultura (MEC), referentes ao Censo Escolar de 2006. Consulta em 20/12/06 no site www.inep.gov.br.
} 
Considera-se que apoiar os educadores na jornada de descoberta das concepções e das ações delas derivadas é buscar maneiras efetivas de construir, com eles, instrumentos capazes de auxiliá-los no processo de desconstrução e reconstrução do fazer educativo junto à criança pequena.

O terceiro fator diz respeito à trajetória profissional da pesquisadora em 24 anos junto ao ensino municipal de educação infantil e suas inquietações relativas à prática docente.

Nesse percurso profissional como docente no ensino municipal de educação infantil e também como formadora de educadores, em vários momentos presenciou importantes avanços no campo, mas também a persistência de práticas preparatórias, onde as crianças são 'treinadas" para desenvolver noções e habilidades com o único intuito de instrumentalizá-las para o processo de alfabetização posterior, em que ficavam claras as escolhas de ações educativas que condenavam a criança a um eterno "vir a ser", desrespeitando seu saber, seu protagonismo e, em última análise, sua infância.

Por fim, o quarto elemento, relacionado ao anterior, que influenciou em grande medida a escolha do tema deste estudo foi a experiência da pesquisadora, como educadora, num processo de inovação da prática pedagógica na EMEI Eurípedes Simões de Paula, que trazia consideráveis diferenças em relação às praticas escolarizantes convencionalmente desenvolvidas na maior parte da rede municipal de educação.

Questionamentos referentes à possibilidade de uma proposta pedagógica diferenciada ser reveladora de ações educativas condizentes com os objetivos estabelecidos para a educação infantil e, ainda, a possibilidade de a reflexão a partir da atuação do educador poder levá-lo a estabelecer uma postura de valorização para a ação da criança foram grandes estímulos para a realização deste estudo.

Foi pela compreensão das práticas educativas e de seu impacto nas ações das crianças que surgiu a forte intenção de um estudo mais profundo e significativo, o que motivou a pesquisadora a buscar na Universidade o respaldo necessário para sua efetivação.

Para compartilhar o percurso de investigação estabeleceu-se parceria com uma educadora responsável pelo agrupamento, que concordou em ter sua prática acompanhada pela pesquisadora durante o ano letivo de 2006, posto que havia estabelecido para si mesma o desafio de rever sua prática pedagógica, 
reconstruindo-a por intermédio da reflexão sobre sua trajetória durante a implantação da proposta de Reorganização dos Espaços e das Atividades junto a sua turma de crianças.

Essa parceria tornou possível a opção pela pesquisa-ação (Elliott, 1990; Gómez, Flores e Jiménez, 1999), tanto pela disponibilidade da educadora quanto pela receptividade de outros membros da unidade educacional: educadoras e equipe gestora. A estratégia metodológica dentro da pesquisa-ação foi a da tutoria entre pares (Duran, 2002, 2004; Miquel, Duran, 2003).

A pesquisa configura-se como um estudo de caso (Yin, 2005; Gómez, 1999), em que se acompanhou uma educadora da Rede Municipal de Educação de São Paulo, empenhada ao longo do ano de 2006 em construir uma prática diferenciada, centrada na atividade da criança, dentro de um espaço escolar previamente reorganizado. Buscou-se identificar as alterações que a educadora foi realizando na sua ação e que pudessem ser atribuídas ao processo de pesquisa-ação / tutoria, observando os efeitos gerados por essas mudanças nas crianças do agrupamento acompanhado.

Considerando: a) que o sistema educacional do Município de São Paulo entende o processo de formação continuada como necessário, instituindo no caso dos educadores da EMEI a possibilidade de uma jornada especial de trabalho que contemple esse período de formação na própria unidade educacional onde atua; b) que é atribuído aos gestores da unidade educacional um papel fundamental no processo formativo dos educadores; c) que as experiências da pesquisadora como educadora nos 24 anos de serviços prestados ao município contemplou raros momentos em que esse processo formativo ocorria de forma aprofundada, efetiva e continuada; d) predominância de práticas de cunho escolarizante nas EMEls da cidade de São Paulo, relacionaram-se as seguintes questões para estudo:

- Pode o educador, com efetiva parceria no processo de formação continuada, desconstruir práticas de cunho escolarizante?

- Os efeitos das alterações realizadas pelo educador na prática pedagógica podem ser observados nas crianças?

- É possível na educação infantil municipal, observando-se as condições físicas, materiais e de proporção adulto-criança, o desenvolvimento de práticas pedagógicas que privilegiem o protagonismo e a ação da criança? 
Para responder a essas questões, partiu-se de algumas suposições relativas ao processo de constituição de práticas transformadoras, vinculadas ao processo formativo da educadora:

- o processo reflexivo do educador, quando fundamentado em análises das práticas concretas por ele efetivadas no contexto educativo, é capaz de gerar avanços significativos dessas ações;

- a verticalização dos processos formativos dificulta a desconstrução de práticas já sedimentadas, criando um abismo entre teoria e prática, sendo a tutoria entre pares uma alternativa eficiente para este processo formativo;

- a proposta pedagógica adotada pela unidade educacional, quando valoriza a ação e o protagonismo da criança, é capaz, por si só, de retirar da ação educativa o caráter preparatório ou escolarizante.

- os efeitos das mudanças efetuadas na prática do educador serão reproduzidos no nível de envolvimento das crianças nas atividades que realizam.

Com o intuito de responder a esses questionamentos, estabeleceram-se como objetivos desta pesquisa:

- identificar as mudanças que a educadora foi realizando no espaço previamente reorganizado e em sua própria prática pedagógica;

- identificar os efeitos de todo esse processo de transformação nas realizações das crianças, considerando seu nível de envolvimento nas atividades como elemento de análise;

- num processo de tutoria entre pares, re-significar em conjunto com a educadora a sua prática pedagógica, entendendo a busca da qualidade da educação infantil como um processo contínuo e progressivo;

- compreender, pelo menos em alguma medida, as possibilidades geradas pela pesquisa-ação e pela tutoria entre pares na formação dos educadores e na desconstrução e reconstrução das práticas pedagógicas.

O trabalho de pesquisa foi projetado para cumprir três fases distintas, mas que se complementavam.

A primeira fase, desenvolvida no período de março a dezembro de 2005 no contexto da pesquisa-ação, destinou-se ao aprofundamento teórico da pesquisadora em questões relativas à metodologia de pesquisa científica, estudo das propostas pedagógicas centradas na atividade da criança, planejamento da pesquisa e 
desenho da investigação, estabelecimento de parcerias com a unidade educacional e a educadora.

O cumprimento dos créditos obrigatórios para obtenção do título de mestre (em disciplinas relacionadas à temática da investigação e atividades programadas junto à orientadora) foi realizado de março de 2005 a julho de 2006. Vale clarificar que embora os estudos relacionados à fundamentação teórica tenham sido priorizados nessa fase inicial da pesquisa, ela aí não se completou: a busca de fontes de consulta estendeu-se até o fim dos trabalhos, visto serem necessários aportes teóricos para subsidiar as observações realizadas e acompanhar mais adequadamente os acontecimentos vivenciados, com vistas à fidedignidade e à seriedade dos resultados do trabalho.

A segunda fase envolveu o acompanhamento da prática pedagógica da educadora, coleta de dados pela pesquisadora e encaminhamento do processo de formação reflexiva educadora/pesquisadora. Esta fase do processo aconteceu durante todo o ano letivo de 2006, conforme descrição mais minuciosa realizada no Capítulo 4 desta dissertação, relacionado aos procedimentos metodológicos adotados.

A coleta de dados comportou dois eixos distintos, porém inter-relacionados. $O$ EIXO 1, que focalizou o processo formativo baseado no acompanhamento da prática pedagógica da educadora; e o EIXO 2, que se deteve nos efeitos dessa prática nas crianças, através de seu envolvimento nas atividades.

Quanto à prática pedagógica, os dados foram coletados através dos registros de campo da pesquisadora (notas de campo, fotos e filmagens), das entrevistas e encontros de tutoria com a educadora e ainda das próprias observações da educadora sobre sua própria prática pedagógica (auto-relatos).

Para acompanhar o efeito dessa prática nas crianças foram utilizados registros de campo (notas de campo, fotos e filmagens) e filmagens específicas relacionadas com a aplicação da Escala de Envolvimento da Criança (The Leuven Involvement Scale for Young Children - LIS-YC), de Ferre Laevers (1994).

Laevers (2000) afirma que os mesmos contextos e a mesma prática educativa não convêm da mesma maneira a todas as crianças e, portanto, se queremos saber se a unidade educacional realiza um bom trabalho, mais do que os meios que ela vai empregar é importante deter-se na análise de seus objetivos e dos efeitos produzidos nas crianças. Pensar em formação do educador e não levar em conta os 
efeitos das práticas nas crianças sob sua tutela seria desconsiderar a perspectiva de qualidade eleita neste estudo.

Decorre dessa crença a escolha da realização da análise da prática educativa acompanhada em 2 eixos distintos mas complementares: 1) formação continuada da educadora; 2) efeitos da prática educativa analisada a partir do envolvimento das crianças nas atividades que realizam.

A terceira fase da pesquisa desenvolveu-se durante o ano de 2007, quando houve reorganização, revisão e análise dos dados coletados e da bibliografia, cruzamento de informações e elaboração final desta dissertação.

Durante todo o processo de investigação, buscando evitar que as expectativas previamente existentes prejudicassem a compreensão dos fatos observados e objetivando fazer prevalecer elementos da realidade, optou-se pela triangulação metodológica e de fontes de dados (Gómez, Flores e Jiménez, 1999; Denzin, 1984), que propiciou a análise da prática real sobre diferentes ângulos, assegurando, na medida do possível, a fidedignidade aos resultados percebidos como decorrentes e relacionados às alterações operadas na prática pedagógica tomada para investigação.

Constatou-se, pelos dados obtidos, que o presente estudo foi capaz de identificar na prática pedagógica da educadora alterações significativas no que se refere ao abandono, pelo menos em parte, do cunho escolarizante dado às atividades propostas. Além disso, foi possível notar a valorização crescente que ela foi atribuindo às ações das crianças, que comportavam atitudes mais autônomas, criativas e voltadas para os seus interesses e necessidades.

Outro fator significativo dos resultados do trabalho partilhado (pesquisadora/ educadora) foi a perspectiva assumida pela educadora de responsabilizar-se pelos acontecimentos que ocorriam na sala de atividades, tendo então um olhar de distanciamento e estranhamento sobre as ações realizadas e seus efeitos sobre as crianças, o que, em última análise, possibilitou a implementação de alterações em sua prática educativa, com vistas ao progressivo aprimoramento dessas ações.

Quanto à organização, o texto apresentado a seguir está dividido em duas partes. A Parte I traz a fundamentação teórica que deu base para o estudo efetivado, já a Parte II refere-se aos procedimentos de pesquisa, aos dados coletados e às análises realizadas a partir deles. 
A Parte I, Fundamentação Teórica, divide-se em 3 capítulos. O capítulo 1 conta com um breve histórico do desenvolvimento das propostas pedagógicas voltadas à educação da primeira infância e vai deter-se com mais profundidade na análise dos modelos pedagógicos High Scope e Reggio Emilia, bem como na proposta designada Reorganização dos Espaços e das Atividades, que era adotada pela unidade educacional acompanhada por ocasião da realização da pesquisa.

O capítulo 2 apresenta algumas considerações sobre modificações ocorridas no papel atribuído à brincadeira infantil em diferentes contextos sociais. Trará ainda alguns dados para a compreensão da brincadeira dentro dos modelos pedagógicos analisados neste estudo.

O capítulo 3 trata de questões relativas ao conceito de qualidade na educação infantil, apontando aspectos relacionados à formação dos educadores como meio para alcançar a progressiva qualidade da prática educativa efetivada e parâmetros de fluxo e envolvimento enquanto indicadores desta qualidade.

$\mathrm{Na}$ Parte II deste trabalho, Estudo Empírico, o capítulo 4 traz informações sobre o contexto da investigação e procedimentos metodológicos adotados. Já o capítulo 5 faz a descrição e análise dos dados obtidos no estudo.

Nessa parte do texto efetuou-se uma subdivisão da prática pedagógica em dois eixos complementares e inter-relacionados: o Eixo I aponta as considerações sobre o processo de formação (tutoria) e seus desdobramentos na prática da educadora. O Eixo II apresenta dados e análises relacionados aos efeitos desse processo de transformação da prática educativa, através da observação dos efeitos no envolvimento das crianças nas atividades que realizam.

Por fim são traçadas as Considerações Finais da pesquisadora a partir do estudo empírico realizado. 
CAPÍTULO 1

REFERENCIAIS PEDAGÓGICOS À PRÁTICA DA EDUCAÇÃO INFANTIL 
$\mathrm{Na}$ esfera mundial, a preocupação com a criança pequena traduziu-se em importantes proposições teóricas no campo da educação para a infância. Ao longo dos tempos e em diferentes espaços históricos, muitas das teorizações sedimentaram-se como modelos pedagógicos, revelando crenças e concepções muito particulares.

Vale esclarecer que neste trabalho entende-se a expressão modelo pedagógico no sentido que lhe é atribuído por Oliveira-Formosinho (2007, p. 29), para quem

[...] O modelo pedagógico baseia-se em um referencial teórico para conceitualizar a criança e seu processo educativo e constitui um referencial prático para pensar antes da ação, na ação e sobre a ação [...] O conceito de modelo pedagógico refere-se a um sistema educacional compreensivo que se caracteriza por combinar um quadro de valores, uma teoria e uma prática [...] no âmbito mais geral do modelo pedagógico, definem-se as grandes finalidades educacionais e seus conseqüentes objetivos. No modelo mais específico do modelo curricular, elaboram-se orientações, umas mais gerais outras mais específicas, no que se refere à prática educacional. O modelo curricular situa-se ao nível do processo ensino-aprendizagem .

Neste capítulo, sem a pretensão de esgotar tão denso assunto, pretende-se expor elementos teóricos constitutivos de modelos pedagógicos que representaram, de alguma maneira, parâmetros para se pensar a proposta pedagógica, fortemente inspirada no socioconstrutivismo, desenvolvida pela educadora Luciana, na Escola Municipal de Educação Infantil Eurípedes Simões de Paula, que teve sua prática pedagógica acompanhada no presente estudo empírico.

\subsection{Breve Histórico do Atendimento à Infância}

Segundo Kishimoto (1988) e Pinazza (1997), as concepções mais relevantes que permanecem nos princípios e práticas da educação infantil têm raízes no pensamento de educadores como Comenio, Rousseau, Pestalozzi e Froebel. Pinazza (ibidem) afirma, ainda, que nas últimas décadas um grande número de estudos sobre a infância traz conceitos teóricos que estiveram presentes, já em outros momentos, nos discursos pedagógicos mundial e brasileiro. 
Alguns marcos históricos merecem destaque. Em 1637, Comenio (1592-1670) publica o plano da unidade educacional maternal onde já previa a educação préescolar, lançando a proposta do uso de materiais audiovisuais para aprendizagem através dos sentidos. Os princípios de Comenius foram reafirmados por Rousseau (1712-1778), que previa uma educação voltada à criança e não aos conteúdos, dando valor à infância e a sua liberdade, à educação sensorial, ao contato com a natureza e na qual propunha o respeito às formas de pensar, ver e sentir que considerava próprias da criança. Os trabalhos de Rousseau influenciaram seguidores como Pestalozzi (1746-1827) que, na mesma linha da educação sensorial, faz mudanças na metodologia, dá início à formação de educadores e cria estabelecimentos para educação de órfãos (Kishimoto, 1988).

Após a criação do jardim de infância em 1840, instituição de caráter educativo, que foi instalada na Alemanha por Froebel (1782-1852), verifica-se a existência de um currículo voltado à criança e há, a partir de então, uma grande penetração desta modalidade de atendimento nos sistemas educacionais de diferentes países.

Os EUA adotam a linha froebeliana para pensar o atendimento à criança pequena, pois os princípios nela contidos vinham de encontro aos da educação americana. O Estado deparava-se com o crescimento das cidades e o aumento da imigração, que trazia a realidade da criança à visibilidade da vida social. Decorre disso o fato de várias entidades filantrópicas dos EUA pensarem o jardim da infância como um antídoto à pobreza e se dedicarem a sua implementação (ibidem).

Kishimoto (1988) ressalta que nesta época vários países europeus estabeleceram instituições para amparar as crianças pobres, mais conhecidas como salas de asilo ou de custódia. A única preocupação era a guarda da criança, o que acontecia em recintos geralmente inadequados.

Na França a "escola para tricotar" surge após 1769, sob a responsabilidade do padre Fréderic Óberlin, uma instituição para atendimento à infância cujos objetivos já incluem aspectos educativos. Com influência de Óberlin, Owen, em 1816 na Escócia, cria a escola infantil para os filhos dos operários, que atendia crianças de 2 a 7 anos e cujo programa educacional previa o processo de alfabetização ocorrendo entre os 3 e 5 anos.

$\mathrm{Na}$ Inglaterra, a experiência de Owen foi adaptada com o nome de "Infant School", uma instituição que atendia até 400 crianças com apenas 1 educador, 
visando a redução dos gastos. Este mesmo modelo de atendimento prolifera-se também na França, contudo vai contra os princípios de Óberlin, já que estas salas de asilo não privilegiavam a espontaneidade e a atividade da criança proposta inicialmente por seu idealizador (Kishimoto, 1988; Spodek e Brown, 1998).

Os princípios de Froebel podem ser identificados na França a partir de 1855, mas sem grande aceitação ainda. É na Itália que esta metodologia vai modificar as práticas das instituições assistencialistas denominadas como "Casas de Custódia", aparecendo em circular governamental de 1879 a inclusão de tais princípios para a educação da infância daquele país (Lola, pp 105-137, in Kishimoto, 1988, p. 14).

Spodek e Brown (1998) estabelecem 4 (quatro) fases históricas ao tratarem dos modelos pedagógicos para a educação da criança pequena. Na primeira fase, encontra-se a fase inicial de desenvolvimento desses modelos, tendo como principais representantes Owen e Froebel, já citados. Segundo os autores eles comportavam uma visão intuitiva da natureza da infância e das crianças.

$\mathrm{Na}$ segunda fase, o conhecimento crescente da forma como as crianças aprendem e se desenvolvem sustentou a formulação do currículo da primeira infância. Os modelos pedagógicos encontravam-se influenciados pelo conhecimento científico de como se daria o desenvolvimento e a aprendizagem pela teoria maturacional. Os principais representantes são: Montessori, que apoiada em estudos antropológicos do desenvolvimento infantil, lança sua proposta de currículo para educação infantil e Gesell, cuja teoria maturacionista teve influência marcante nos jardins de infância e nos infantários dos EUA (ibidem, p. 42).

Nos EUA, Dewey e Kilpatrick valorizam o jogo, a atividade, a vida social e a cooperação na educação da infância. Na Itália, as irmãs Rosa e Carolina Agazzi criaram, em 1894, o método Agazzi, que incluía a sucata entre seus materiais. $\mathrm{Na}$ Itália, Montessori, assentada em princípios de liberdade, atividade e necessidade de um ambiente adaptado, desenvolveu um método para atender a criança pequena. Na Bélgica, Ovide Decroly, em 1925, influenciado por Dewey, cria o método dos centros de interesse, bem como diversos jogos de larga utilização na educação infantil (Kishimoto, 1988).

Para Spodek e Brown $(1998,2002)$, a terceira fase tem como característica a pluralidade de modelos, baseados na variedade de teorias e pressupostos acerca da aprendizagem e do desenvolvimento da criança. Essa fase predominou nos anos $60 / 70$. 
A fase contemporânea é marcada pela modificação dos modelos pedagógicos já existentes, nem sempre com a devida coerência entre a prática pedagógica efetivada e o posicionamento teórico, o que se revela na propensão dos professores em adotar estratégias que "funcionem" com seu agrupamento, independentemente de serem ou não consistentes com o modelo proposto pela unidade educacional. Os autores definem que essas abordagens podem ser classificadas em quatro categorias gerais: os programas Montessori, os programas behavioristas, os programas de educação aberta e as abordagens construtivistas (Ibidem, p. 204).

Kishimoto (1988) lembra ainda que os estudos de psicologia genética encabeçados pelo grupo de Genebra, entre eles Claparède e Piaget, encarregam-se de trazer novas informações sobre o desenvolvimento infantil e contribuíram para a estruturação de atividades pré-escolares. Para Spodek e Brown (2002) os modelos pedagógicos de inspiração construtivista se desenvolveram a partir da obra de Jean Piaget. Contudo, o fato de este teórico não ter intencionado a tradução de seu trabalho diretamente para a prática educativa, fez com que seus estudos pudessem se revelar em diferentes interpretações. Pensando nesse aspecto, Forman e Frost (1982, IN: SPODEK e BROWN, 2002), em estudo comparativo, agregaram os modelos piagetianos em 4 categorias, conforme a sua proposição básica: 1) a fonte do pensamento é a ação e não a lógica; 2) a compreensão resulta de atividades auto-reguladoras; 3) a aprendizagem significativa resulta da resolução de conflitos; 4) as correspondências e as transformações devem ser coordenadas.

Dada a polissemia do conceito de construtivismo, vale salientar que, neste trabalho, adotou-se a perspectiva interpretativa de Coll (1990, 2001, in OliveiraFormosinho, 2001, p.90), para quem a

[...] concepção construtivista da aprendizagem escolar situa a atividade mental construtiva do aluno na base dos processos de desenvolvimento pessoal. Com base na realização de aprendizagens significativas o aluno constrói, modifica, diversifica e coordena seus esquemas estabelecendo redes de significados que enriquecem o conhecimento do seu mundo físico e social e potencializam seu crescimento pessoal [...]

Um ponto comum entre as propostas de inspiração construtivista é a idéia de que a criança deve estar ativamente envolvida na aprendizagem e constrói seu 
conhecimento a partir da interação com o mundo que a rodeia, sofrendo influência do contexto onde está inserida.

Há, porém, diferença marcante no que se refere aos desdobramentos deste princípio de aprendizagem ativa. Segundo Oliveira-Formosinho (2001), para Piaget o essencial é a interação do sujeito com o mundo material, já para Vygotsky a atividade educativa é inseparável da interação com os adultos ou companheiros mais experientes, visto que este é o caminho para elaboração do sujeito de seus instrumentos cognitivos (funções psicológicas superiores). Vygotsky atribui importância central à dimensão sócio-histórica do funcionamento psicológico, pois as aprendizagens ocorrem em contextos sociais mediados por processos interpessoais.

Vale ressaltar que na concepção construtivista o papel ativo e protagonista da criança não se contrapõe à necessidade de um papel igualmente ativo por parte do educador. A intervenção pedagógica é entendida como fonte de ações que apóiam esta construção particular da criança (Zabala, 2002).

A intervenção do educador vai tomar diferentes caminhos de acordo com a perspectiva adotada. Para Piaget o papel do educador orienta-se para propor as melhores situações possíveis para que o sujeito possa construir o conhecimento e refletir sobre a ação; já para Vygotsky, na perspectiva sócio-construtivista, o funcionamento mental superior é mediado por instrumentos técnicos e por signos psicológicos, sendo que os artefatos culturais e os instrumentos culturais de representação e comunicação fazem a mediação entre o indivíduo e os grupos sociais e entre ele e os demais contextos (Ibidem).

Os modelos de inspiração construtivista e socioconstrutivista têm hoje, no panorama mundial, uma grande influência na práxis realizada junto à criança pequena, tendo marcante presença em países como Portugal, Itália, Inglaterra, EUA, Brasil, entre outros.

Como ressalta Oliveira-Formosinho (2001) a perspectiva epistemológica construtivista é a fonte central do modelo High Scope e fonte importante da proposta educativa de Reggio Emilia².

No Brasil, particularmente esses dois modelos pedagógicos e as discussões relacionadas à autonomia e construção de significados pela criança despertam

\footnotetext{
${ }^{2}$ Os modelos pedagógicos High Scope e Reggio Emilia serão tema de discussão adiante.
} 
progressivo interesse nos educadores, o que pode ser notado no grande número de publicações e eventos que objetivam discutir a práxis a partir destes referenciais.

\subsection{Panorama Histórico da Educação Infantil no Brasil e em São Paulo}

Neste item, pretende-se traçar um breve histórico da educação infantil no Brasil, com um foco especial à realidade vivida pelo Município de São Paulo, a partir de 1935, visto o estudo empírico ser realizado numa unidade educacional de Educação Infantil vinculada à rede municipal.

As instituições de educação infantil surgem no Brasil por volta de 1870. Houve alguns projetos organizados por grupos particulares para atendimento à infância, geralmente voltados às questões médicas e higienistas. Esses projetos resultaram em poucas ações práticas.

Nesta época, mais que as questões educacionais a grande preocupação estava voltada à grande incidência de mortalidade infantil e ao abandono das crianças. As causas destes males eram atribuídas à família: falta de cuidados destinados à criança, amamentação feita por mulheres especialmente destinadas a esse fim, dentre outras questões relacionadas à saúde e higienização (Kramer, 1992).

Em 1875, foi inaugurado no Brasil o primeiro jardim da infância particular na cidade do Rio de Janeiro, pelo médico Menezes Vieira, fechado logo a seguir por falta de apoio institucional. Kishimoto (1985) esclarece que essa instituição tinha caráter pedagógico e era marcada pelas características do ensino froebeliano, destinando-se apenas ao atendimento dos filhos das classes mais abastadas.

Dois anos depois, em 1877, foi criado o primeiro Kindergarten da Escola Americana, em São Paulo. Em 1879 a Reforma Leôncio de Carvalho (decreto no 7.247, de 1879) modificava o ensino primário e previa jardins de infância nos municípios da Corte (Kuhlmann, 2000).

Em 1896, inaugurou-se em São Paulo o primeiro jardim da infância da rede oficial, o jardim-de-infância Caetano de Campos, mas seu atendimento também estava voltado ainda à elite (Kishimoto, 1985).

Várias leis promulgadas nessa época propiciaram a criação de instituições para atender a infância nas áreas de higiene infantil, médica e escolar. Em 1899, fundou-se o Instituto de Proteção e Assistência a Infância no Brasil, com o objetivo 
de atender crianças menores de 8 anos em diferentes esferas, indo desde a construção de creches, maternidades e jardins de infância até a criação de leis para a proteção dos direitos das crianças ou para definir ações de saúde (entre outras). A esse tempo, o atendimento à criança era de caráter médico, com poucas iniciativas educacionais voltadas para essa faixa etária (Kramer, 1992).

Entre 1901 e 1910 são criadas várias instituições para atendimento à infância no estado de SP. A Associação Beneficente Anália Franco cria 18 escolas maternais e 17 creches-asilo. Em 1908 o Rio de Janeiro inaugura a creche central e a prefeitura de Belo Horizonte a sua escola infantil. Em 1909 o Rio de Janeiro cria os jardins de infância municipais (Kuhlmann, 2000).

Os jardins de infância eram destinados ao atendimento dos privilegiados da elite, enquanto as escolas maternais e creches destinavam-se aos pobres e eram ligados à assistência social ou órgãos de saúde pública (Kuhlmann, 2000).

Pinazza (2005) refere-se à questão pedagógica dos jardins de infância e, com base em análise de periódicos oficiais do final do século XIX e início do século XX, afirma que havia uma preocupação exacerbada com a intelectualidade infantil, apesar de a proposta da pré-escola da época estar inspirada em Froebel. Tal preocupação afastou a prática pedagógica das concepções de educação integral de Froebel, sendo suas idéias apropriadas de maneira inadequada e fazendo com que o jardim de infância se aproximasse do modelo de ensino escolar e tivesse sua prática reduzida apenas aos dons e ocupações, ações discrepantes dos princípios originalmente anunciados por ele.

Segundo Kishimoto (1986, in Pinazza, 1997), na cidade de São Paulo é somente a partir da década de 20 que começa haver melhor qualidade das instalações e dos serviços prestados às crianças com a criação das creches próximas das fábricas paulistas. As escolas maternais serão criadas em meados da década de 20, sendo subsidiadas e inspecionadas pelo Governo do Estado.

Neste trabalho, terão destaque os fatos históricos relacionados à educação infantil em São Paulo no atendimento das crianças de 3 a 7 anos, realizado nas unidades educacionais ligadas à Secretaria Municipal de Educação.

Cabe enfatizar que $\mathrm{o}$ atendimento da criança realizado nas creches teve percurso diferenciado durante longo tempo, não vinculado aos órgãos da educação, mas sim aos órgãos da saúde e bem-estar social. Por isso não serão alvo de análise no presente trabalho. 
Kishimoto (1988) afirma que os asilos infantis e as creches que têm finalidades puramente assistenciais naquele momento não fazem parte do sistema pré-escolar, pois não possuem fins educativos. As escolas maternais podem ser consideradas como estabelecimentos de transição, já que nascem com certas características educativas e vão se transformar nos anos 20 e 30 em unidades que agregam as questões assistencialistas e educativas nos serviços que prestam aos filhos dos operários.

Pinazza (1997, p. 106) destaca a importância dessas instituições;

A criação de escolas maternais na década de 20 representa um marco importante na constituição do campo da educação pré-escolar, na medida em que significou a ampliação dos serviços públicos nessa área, com uma proposta diferenciada dos asilos infantis e creches.

Nessa época persistiu a lógica de os jardins de infância, com inspiração froebeliana e no modelo francês de antecipação da escolarização, serem destinados ao público infantil mais abastado, enquanto as escolas maternais e creches destinavam-se às crianças provindas do proletariado.

À semelhança de outros países, o Brasil e, em especial, São Paulo, reproduziu a história dos estabelecimentos de atendimento à infância. Desde 1920 a legislação paulista prevê a instalação de escolas maternais e creches. Eram instituições voltadas ao proletariado e geralmente localizadas perto das fábricas. Em 1923 e depois em 1932 (integrando-se à Consolidação das Leis do Trabalho (CLT) a legislação vai prever a instalação de creches em locais onde trabalhem mais de 30 mulheres, visando facilitar a amamentação durante a jornada de trabalho). (Kuhlmann, 2000). Vale ressaltar que, apesar disso, é apenas em 1961, com a Lei de Diretrizes e Bases da Educação (LDB n 4024) que essas orientações tornam-se nacionais, correspondendo às exigências da legislação trabalhista.

Em 1935, criou-se o Departamento de Cultura no Município de São Paulo e começa a se estruturar uma nova instituição: o parque infantil. $O$ atendimento de crianças de 3 a 6 anos e de 7 a 12 anos era feito fora do horário escolar, baseava-se nas idéias de Mário de Andrade que valorizavam a nacionalidade através da utilização do folclore, da produção cultural e artística, dos jogos infantis e das brincadeiras (Kuhlmann, 2000). 
O Serviço Nacional de Parques Infantis, criado em 1935, tinha como justificativas suprir as carências de higiene e saúde e tirar crianças e adolescentes da rua, num esforço de evitar a criminalidade (Oliveira,Z.M.R, 1985).

A família continuava, nessa fase, sendo culpabilizada pela situação da criança. O Estado assume a assistência social à infância, porém o faz convocando entidades e associações particulares e beneficentes para realizar o apoio financeiro necessário para a execução dessas ações assistenciais e educativas. Afirma Kramer (2001, p. 61) que:

[...] percebem-se duas tendências que até os dias de hoje caracterizam o atendimento à criança em idade pré-escolar: o governo proclama(va) a sua importância e mostra(va) a impossibilidade de resolvê-lo dadas as dificuldades financeiras em que se encontra(va), enquanto imprimia uma tendência assistencialista e paternalista à proteção da infância brasileira [...]

$\mathrm{Na}$ década de 40 , os parques infantis expandem-se para outras localidades do país. Em 1942 existiam 7 parques infantis na cidade de São Paulo. Em 1955 já eram 50 e, em 1956 já se somavam 84 unidades, mostrando o maior investimento do Estado em ações junto às crianças e adolescentes mais pobres (Oliveira,Z.M.R, 1985).

Segundo Faria (1999), os parques infantis podem ser considerados a origem da rede de educação infantil paulistana, "a primeira experiência brasileira pública municipal de educação (embora não escolar) para crianças de famílias operárias que tiveram a oportunidade de brincar, de ser educadas e cuidadas, de conviver com a natureza, de movimentarem-se em grandes espaços", onde era desenvolvido o tríplice objetivo parqueano: educar, assistir e recrear.

A educação infantil brasileira passou nesse período por um processo lento de expansão, permanecendo vinculado aos setores de assistência o atendimento da criança de 0 a 3 anos, e à educação o atendimento da criança de 4 a 6 anos.

Segundo Kuhlmann (2000, p. 492) o investimento do governo federal teve grande declínio a partir de 1968, passando de $11,8 \%$ do orçamento de 1967 para a educação para apenas 5,5\% em 1974, atingindo 7\% em 1976. A legislação militar de 1967 extinguiu os preceitos da legislação de 1946 que exigiam o mínimo de investimento de $10 \%$ do total arrecadado com impostos para a área da educação. Esta opção governamental teve conseqüências, principalmente no que se refere à dificuldade de expansão do atendimento. 
A partir de 1972, os parques infantis começaram a atender apenas crianças de 3 a 7 anos. Transformaram-se em outra proposta de instituição, sob a designação de Escolas Municipais de Educação Infantil (EMEIs). Como resultado dessas mudanças, operadas no atendimento, passou a ser exigida habilitação específica para os educadores, no caso a formação de segundo grau, curso de magistério.

Embora a EMEI seja tributária dos jardins de infância e dos parques infantis, tendo herdado a estrutura física e várias estruturas de funcionamento administrativo, nasceu com características próprias, com visível caráter instrucional e, mesmo, compensatório, o que a fazia distinta das modalidades que a antecederam, no que tange à concepção de atendimento e práticas desenvolvidas.

Em São Paulo, entre 1974 e 1976, aumenta consideravelmente o número de salas pré-escolares, instaladas nas escolas de primeiro grau (atual ensino fundamental), com objetivo de "preparar" a criança para a alfabetização. Nessa época, a alta demanda motivou a criação de um terceiro turno de atendimento nas escolas municipais e o rodízio de salas (2 ou 3 turmas usavam o espaço de uma mesma sala de aula e as áreas externas em sistema de rodízio de atividades). Também resultou na diminuição do atendimento em período integral, visando expandir o número de vagas oferecidas (Oliveira, Z.M.R, 1985).

A partir da década de 80 , ampliaram-se as discussões sobre o caráter pedagógico da educação infantil, defendida como meio de garantir o desenvolvimento cognitivo e lingüístico da criança. Criaram-se órgãos municipais de suporte e orientação pedagógica às escolas de educação infantil, normatizaram-se as carreiras dos educadores. Houve realização de concursos públicos para provimento dos diferentes cargos que fazem parte do quadro de profissionais da educação municipal. Nessa época, cada educador era responsável por um agrupamento com 45 a 55 crianças, separadas pelas faixas etárias de 4 a 6 anos.

Essa transformação do papel educacional foi acompanhada de intervenções marcantes de mulheres em causas sociais, de movimentos populares e de levantes de grupos políticos em oposição à ditadura militar. Tais manifestações incorporavam a reivindicação por creche no quadro das bandeiras pela redemocratização. Toda essa movimentação da sociedade civil juntou-se às indicações de estudos e pesquisas realizadas no campo educacional que acenavam para os benefícios da educação infantil, resultando em forte impacto sobre a esfera institucional, revelado no texto da Constituição Federal, em 1988, em que creches e pré-escolas foram 
definidas como direito dos cidadãos e incorporadas aos sistemas educacionais. Mais tarde, em 1996, tais disposições surgem mais especificadas no texto Lei de Diretrizes e Bases da Educação Nacional (LDBEN n‥ 9394, de 20/12/96).

Com a Constituição Federal de 1988, previu-se o atendimento da criança de 0 a 6 anos na educação infantil. Iniciaram-se vários processos de integração entre as secretarias municipais, visando a saída das creches da área de Assistência Social e sua incorporação ao sistema educacional dos municípios.

Em 2001, pelo Decreto Municipal no 40268 de 31/01/01, as creches passaram efetivamente a compor a rede municipal, ficando sob a responsabilidade da Secretaria Municipal de Educação o atendimento a crianças de 0 a 6 anos. A partir de então registram-se vários programas do município voltados à formação continuada dos profissionais de educação infantil, objetivando a adequação do quadro de funcionários à legislação em vigor (LDB n 9394, de 20/12/1996), que institui a graduação (nível universitário) como obrigatória para a formação básica dos educadores e coloca como grau mínimo possível a formação de segundo grau, habilitação para o magistério de educação infantil e séries iniciais.

Um olhar sobre a prática educativa, mesmo que resultante de observações assistemáticas, permite inferir que a função preparatória da educação infantil para a alfabetização ainda é partilhada por grande parte dos educadores e pela maioria das famílias atendidas, que vêem na educação infantil uma forma de garantir o sucesso escolar posterior dessa criança.

Quanto aos professores, o discurso não comporta essa perspectiva, porém a prática contradiz esse discurso, predominando as atividades de coordenação motora e letramento, descontextualizadas, e nas quais são ignorados o protagonismo das crianças, suas necessidades e interesses reais.

A partir da década de 90, especialmente dois modelos pedagógicos têm sido muito discutidas no âmbito da Secretaria Municipal de Educação de São Paulo, o que imprime nas práticas e, sobretudo, no discurso pedagógico, marcas significativas. Esses modelos contemporâneos de inspiração sócio-construtivista são o Currículo High Scope e o modelo pedagógico de Reggio Emília.

Além desses dois modelos pedagógicos, será analisada uma proposta curricular que ocorria na unidade educacional no momento da realização do estudo empírico, tendo sofrido influências dos modelos pedagógicos anteriormente citados. 
Tal proposta curricular foi gestada na unidade educacional em que a investigação se efetivou e recebeu de suas idealizadoras ${ }^{3} 0$ nome de Reorganização dos Espaços e das Atividades. Essa proposta passou a nortear o trabalho na unidade, promovendo alterações no currículo e conseqüentemente na prática pedagógica da educadora e nas possibilidades de ação das crianças que foram sujeitos da pesquisa.

Com clareza da impossibilidade de aprofundamento, neste trabalho serão analisados os modelos pedagógicos High Scope e Reggio Emilia. Também será especificada a proposta Reorganização dos Espaços e das Atividades. Merecerão destaque as questões relacionadas: à rotina, ao espaço, à brincadeira e ao tipo de atividade proposta, por serem esses elementos os eixos organizadores do trabalho pedagógico, em que se refletem com maior evidência as concepções de criança e de educação. Mais adiante, no Capítulo 2, será tratada com mais detalhes a temática da brincadeira.

\subsection{Modelo Pedagógico High Scope}

O currículo High Scope, iniciado em 1960 por David Weikart, em Michigan, EUA, encontra-se agora em sua quarta fase (Oliveira-Formosinho, 1998). No início de suas atividades tinha uma característica compensatória, destinado à educação de crianças portadoras de necessidades especiais, e o currículo era dirigido ao desenvolvimento intelectual da criança, mas a educação já era feita através da atividade da mesma, fugindo das concepções behavioristas dominantes à época.

$\mathrm{Na}$ segunda fase, durante os anos 60 , o atendimento é expandido às demais crianças. Suas atividades visavam estimular o desenvolvimento psicológico e gerar avanços para estágios superiores de desenvolvimento. Há então uma grande influência dos estudos de Piaget sobre o processo de construção de conhecimentos da criança. Nesse momento, cria-se uma rotina pedagógica que vai orientar a ação do educador.

$\mathrm{Na}$ terceira fase, nos anos 70 , houve uma reconceitualização do papel do adulto, sendo menos diretivo e mais de apoio e suporte. As atividades pedagógicas são organizadas ao redor de experiências chaves para a criança.

\footnotetext{
${ }^{3}$ Por ocasião do estudo empírico todas as educadoras responsáveis pela elaboração e execução da proposta pedagógica da unidade educacional acompanhada eram do sexo feminino.
} 
Nos dias atuais, o professor tem seu papel modificado, sendo membro ativo do processo, responsável pelo preparo do ambiente e das possibilidades que ele encerra, e um observador da atividade da criança para, a partir disso, propor novos desafios e replanejar. O objetivo é a maior ação por parte da criança, com maior poder de decisão desta.

Dentro da perspectiva High Scope, a ênfase no processo de construção de conhecimento está visível e tem como finalidade a conquista da autonomia intelectual da criança. A filosofia educacional, a concepção de espaço e material, a rotina, a concepção do papel do adulto estão vinculados a esse objetivo maior.

O modelo pedagógico High Scope conta com um instrumento de avaliação do grau de consecução da proposta (Program Implementation Profile - PIP), que se organiza em quatro seções e traça, em linhas gerais, as propostas de atuação do educador para um trabalho de qualidade junto à criança. O PIP envolve os aspectos relacionados ao ambiente físico, à rotina diária, à interação adulto-criança e adultoadulto, servindo como parâmetro de análise do atendimento oferecido.

Weikart e Hohmann (2004) afirmam que os princípios básicos do modelo pedagógico High Scope são: aprendizagem pela ação, interações positivas entre adulto e criança, ambiente de aprendizagem agradável, rotina diária consistente e avaliação diária da criança baseada no trabalho em equipe. A aprendizagem pela ação é a base principal e definida pelos autores como [...] viver experiências diretas e imediatas e retirar delas significado através da reflexão. As crianças pequenas constroem o conhecimento que as ajuda a dar sentido ao mundo (ibidem, p. 5).

Os autores enfatizam que o sucesso na implementação da proposta reside no importante papel do adulto na geração de interações positivas com a criança e no apoio a suas iniciativas em termos de experiências chaves.

$\mathrm{Na}$ abordagem High Scope o espaço é um dos aspectos fundamentais, como portador de mensagens implícitas sobre ordem, estímulos oferecidos, possibilidade de protagonismo da criança e é proposto como forma fundamental de intervenção do educador no currículo.

Referindo-se à organização espacial do ambiente de uma sala High Scope, Oliveira-Formosinho (1998) destaca que existem áreas diferenciadas para permitir diferentes aprendizagens e que cada área é pensada para oferecer à criança imersão no cotidiano através de diferentes experiências de papéis sociais. $O$ ambiente também promove a escolha do fazer da criança, ou seja, seu 
protagonismo. O que definirá as áreas em que a criança vai atuar é seu projeto inicial de trabalho e não o contrário. O uso das áreas e materiais ali disponíveis será apenas o apoio, o meio utilizado pela criança para concretização desse projeto, sendo também as áreas externas concebidas com diferentes propostas pelas quais a criança pode optar livremente.

O espaço organizado pelos educadores e seus equipamentos são decisões orientadas pelos seguintes princípios de ação:

- espaço atraente para a criança, dividido em áreas de interesse bem definidas, de forma a encorajar diferentes tipos de atividades;

- áreas organizadas de modo a assegurar visibilidade dos objetos e materiais, bem como locomoção entre as diferentes áreas;

- materiais e objetos numerosos, de forma a garantir uma grande variedade de brincadeiras;

- espaços modificam-se para acolher novos interesses das crianças;

- materiais e objetos refletem o tipo de vida e experiências familiares das crianças;

- crianças têm acesso aos materiais e são responsáveis por sua organização após a brincadeira (Weikart e Hohmann, 2004).

Embora a rotina defina o dia em blocos identificáveis e destinados a tipos específicos de atividades, ela não dita os pormenores daquilo que a criança fará em cada período da atividade.

A rotina diária ajuda a criança desenvolver um sentimento de segurança e controle e ainda mantém equilíbrio entre limites e liberdade. Apóia-se num planejamento cuidadoso e bem definido pelo adulto, ao mesmo tempo em que precisa ser flexível a ponto de responder de forma apropriada aos interesses e idéias espontâneas da criança (Ibidem).

No currículo High Scope o cuidado com a rotina é tão necessário quanto com o espaço, pois a organização do tempo é tida como forma de possibilitar à criança uma atuação mais independente do adulto, garantindo seu protagonismo nas atividades que realiza e ainda sua liberdade de escolha e de experimentação.

A rotina é estável e previsível para a criança e permite ao educador criar maiores oportunidades para todas ao mesmo tempo em que contempla, simultaneamente, as necessidades particulares de cada uma delas. Na rotina estão previstos trabalhos em grandes e pequenos grupos, tempos de utilização da área 
externa, tempos de transição, tempos para comer e descansar, além da seqüência básica da proposta que estimula a criança a refletir sobre suas realizações através do ciclo planejar/fazer/rever (Oliveira-Formosinho, 1998).

Percebe-se que os pressupostos que norteiam a ação nessa abordagem, embora considerados quase impossíveis na realidade brasileira e paulista atual, são vistos por vários grupos de educadores como adequados à educação da criança pequena.

\subsection{Modelo Pedagógico de Reggio Emília}

Reggio Emília é uma cidade no Norte da Itália cujo sistema de educação municipal tem como objetivo uma educação pautada na igualdade de oportunidades, em que sejam proporcionados à criança espaço e tempo para desenvolvimento de suas potencialidades.

Em 1945, logo após a Segunda Guerra Mundial, os habitantes dessa região reuniram-se para construir uma escola para crianças pequenas. Houve cooperação entre as famílias e a comunidade e logo foram construídas outras sete escolas, principalmente na periferia e bairros pobres. Essa perspectiva de cooperação e colaboração família/escola/comunidade tornou-se, desde então, uma característica dessas unidades, que perdura até os dias atuais.

Loris Malaguzzi, um jornalista e professor que acompanhou as famílias neste processo de construção das escolas e que lecionava, na época, numa escola subsidiada pelo estado, deixou seu emprego e dirigiu-se a Roma para estudar Psicologia. Ao retornar para a região de Reggio Emilia abre, subsidiado pela municipalidade, um centro de saúde mental destinado ao atendimento de crianças com dificuldades de aprendizagem e desenvolve, em paralelo, um trabalho com as escolas da região que haviam sido fundadas e eram geridas pelos pais das crianças que as freqüentavam (Gandini, 1999).

Nesse tempo, Malaguzzi coordenou uma equipe de professores com diferentes filosofias educativas. Depois de um tempo volta a Roma, onde faz cursos sobre educação da infância, retornando posteriormente para partilhar com os professores e pais as novas idéias e construindo conjuntamente um currículo voltado à criança pequena. 
Em 1963, surgiriam as primeiras escolas subsidiadas financeiramente pelo município, mantendo-se a perspectiva de construção conjunta de saberes escola/família/comunidade. Em 1968, foi promulgada lei que estabelece subsídio para educação de todas as crianças de 3 a 6 anos (Gandini, 1999).

No modelo de Reggio Emilia existem alguns princípios que indicam o caminho para as práticas pedagógicas. A unidade de educação infantil é encarada como local de múltiplas relações, de muitos adultos com muitas crianças e de crianças entre si, ou seja, um local de vidas compartilhadas onde 0 ato de educar envolve personagens que estão além dos muros da unidade educacional, nas famílias e na comunidade.

Educar é um ato coletivo que reúne professores e famílias no trabalho colaborativo e atuante. Não há ações isoladas: são a parceria e o processo de reflexão constante que possibilitam o crescimento na qualidade de atendimento à criança pequena.

Enfatiza Lino (1998) que nessa abordagem a criança tem papel ativo na construção de conhecimentos, sendo a aprendizagem e a compreensão do mundo estimuladas e contextualizadas socialmente, havendo também grande preocupação com o ambiente físico e emocional oferecido às crianças.

Faria (2007, p. 282) refere-se à pedagogia praticada hoje em Reggio Emilia e vem esclarecer:

[...] Malaguzzi é considerado o promotor das novas orientações para uma escola da infância, em vigor desde 1991. Essa criança inteira precisa de uma educadora de criança e não de uma educadora de disciplina, de matéria escolar. Assim, as novas orientações curriculares organizam-se com os campos da experiência educativa, a saber: a) corpo e movimento; b) os discursos e as palavras; c) o espaço, a ordem e a medida; d) as coisas, o tempo e a natureza; e) as mensagens, as formas e a mídia; f) o eu e o outro.

A proposta da pedagogia de Reggio Emília fez uma opção pela educação estética, pelo acolhimento das diferenças e pela plena confiança na possibilidade de a criança ser produtora de conhecimento. Essa criança precisa de um educador atento, disponível e que acredite em seu potencial.

Para essa educação, o espaço assume papel fundamental, considerado como o terceiro educador do agrupamento, sendo encarado como elemento que possibilita a integração dos indivíduos, o registro do que ali acontece e ainda como o suporte 
da ação que pode garantir o bem-estar de cada criança e do grupo como um todo (Gandini, 1999).

O espaço tem uma organização própria, sendo constantemente repensado à luz das experiências ali vividas e os desdobramentos que elas possibilitam. Em Reggio Emilia, conforme afirmação de Lino (1998, p. 107), o modo como o espaço está organizado reflete as idéias, valores, atitudes e o patrimônio cultural de todos que nele trabalham.

As escolas são construídas e organizadas para contemplar as interações e a exploração pelas crianças, tendo como objetivo favorecer a cooperação entre todos os envolvidos: pais, professores, crianças e outros membros da comunidade. Apesar do modelo pedagógico com princípios comuns, não existe um modelo arquitetônico único para todas as unidades, visto que elas atendem também perspectivas e objetivos particulares do grupo de famílias que dela faz parte, porém a maioria contempla o atendimento médio de 60 crianças, divididas em três agrupamentos (Gandini, 1999).

Nessa abordagem o espaço não é visto como algo neutro, circunstancial ou alheio ao processo de ensino-aprendizagem. Ele é motivo de constante reflexão, intervenção e reavaliação em termos de consonância com os objetivos educacionais estabelecidos pelo modelo pedagógico.

Há nas salas a divisão em áreas com materiais específicos para cada tipo de atividade ali desenvolvida, existe ainda um pequeno ateliê para cada agrupamento de crianças, bem como, atendendo a todos os agrupamentos etários (geralmente 3 por unidade educacional), uma biblioteca, um ateliê, uma sala de registro, um espaço central comunitário chamado de piazza, além da área externa.

O espaço externo da unidade também é pensado e organizado para possibilitar à criança opções de diferentes experiências e atividades diversas. Os espaços que vão além dos muros, como a comunidade, o bairro e a cidade, também são considerados educativos, havendo constante interlocução entre eles e a unidade educacional.

No modelo de Reggio Emilia, a rotina e o tempo também têm uma conotação particular. É a necessidade e o ritmo das próprias crianças que determina a cadência das atividades. A rotina é pensada de maneira a garantir educação e cuidado, respeito aos ritmos pessoais e proporcionar diferentes tipos de desafios, ao mesmo tempo em que possibilita um sentimento de segurança e auto-estima na criança, 
permitindo-Ihe realizar atividades envolventes e desafiadoras, sempre contando com estímulo e apoio dos adultos.

Os projetos que surgem de diferentes interesses das crianças são estimulados e ampliados pelos adultos e têm diferentes durações, de acordo com a idade das crianças e, principalmente, por estarem relacionados à continuidade desse interesse pelos protagonistas. Os projetos podem ser realizados em pequenos ou grandes grupos e durar de dias a meses. Além dessas características de respeito a cada indivíduo (na sua maneira e tempo de aprender), não há rompimento a cada novo ano escolar, visto que as crianças são acompanhadas pelos mesmos professores durante os anos iniciais de creche ( 0 a 3 anos) e depois por outros professores, dos 3 aos 6 anos (Gandini, 1999).

\subsection{Contextualização de Modelos Pedagógicos na educação da infância no Município de São Paulo}

Alguns esforços vêm sendo empreendidos por diferentes unidades educacionais do Município de São Paulo para contextualizar os modelos High Scope e Reggio Emilia.

Embora contextualizadas em unidades educacionais de diferentes países, após a breve descrição destas propostas nota-se, mesmo a partir de observação assistemáticas, como esta perspectiva de trabalho está distante da realidade hoje das EMEls, em termos de condições materiais e de recursos humanos, para que possam ser aplicadas integralmente.

Algumas unidades estão realizando "adaptações" deste Modelo Pedagógico, não há, porém, estrutura de apoio suficiente como amplos espaços, diversidade de materiais, formação dos profissionais e a proporção adulto/criança compatíveis com a execução dessa proposta.

No caso do modelo pedagógico de Reggio Emília isso fica ainda mais difícil, pois hoje as famílias, a comunidade e a instituição de educação infantil não formam contextos integrados e sintonizados em termos de objetivos e práticas educativas. As observações da pesquisadora, resultantes de longa experiência como profissional da rede municipal de educação, permite afirmar que em algumas unidades educacionais não existe sequer a interlocução entre esses três vértices (família, comunidade e instituição educacional), desconsiderando o fato de que é 
imprescindível à educação da criança pequena o envolvimento de outros atores sociais para além daqueles presentes nas instituições de educação infantil.

Ademais, um trabalho mais efetivo na direção de maior integração famíliacomunidade-instituição é bastante dificultado dado o tamanho das EMEls, que atendem a um público que pode variar aproximadamente de 400 a 1000 crianças. Raramente essas unidades têm menos de 400 crianças atendidas diariamente.

A visão preparatória da educação infantil para o ensino posterior ainda é predominante entre muitos educadores nas EMEls e inviabiliza, em grande medida, a aceitação de práticas em que se promova o protagonismo da criança e a aprendizagem pela ação.

A rotatividade de educadores dificulta o conhecimento mais profundo das singularidades das crianças bem como o aprofundamento de vínculos destes educadores com as famílias atendidas.

Portanto, os esforços em conseguir um trabalho articulado entre a família, comunidade e a instituição de educação infantil esbarram em uma deficitária estrutura organizacional do serviço público municipal, cujas limitações expressam-se na persistência de condições desfavoráveis, tais como: alta rotatividade de pessoal, expansão do atendimento em detrimento da qualidade do serviço prestado, proporção adulto-criança inadequada, que inviabiliza muitas ações, entre outras.

\subsection{Proposta curricular da unidade em estudo: Reorganização dos Espaços e das Atividades}

Na unidade educacional em que a pesquisa desenvolveu-se, um processo de discussão sobre a prática pedagógica teve início no ano de 2000 . Entre avanços e dificuldades, foram elencados princípios derivados das concepções presentes na unidade, bem como as ações deles decorrentes, que norteariam todas as intervenções educativas junto à criança pequena.

Dessa negociação em torno do estabelecimento de princípios, resultou a proposta de reorganizar o trabalho efetivado de modo a atender os aspectos acordados.

O esforço de mudança revelou-se numa reorganização que tomava espaços e tempos e pretendia modificar as atividades desenvolvidas tanto pelo educador, para dar suporte à aprendizagem da criança, como também pelas próprias crianças, no 
que diz respeito a sua ação. Para diferenciar a proposta de trabalho que se pretendia implantar daquela que se encontrava em vigor na unidade, a equipe criou uma designação especial: Reorganização dos Espaços e das Atividades.

Durante o estudo empírico realizado na unidade de educação infantil, foi possível identificar que a referida proposta havia cumprido duas fases distintas de sua implantação. A primeira fase estendeu-se de 2000 a 2004 e caracterizou-se pelas discussões preliminares em torno da prática vigente e pelo início da implantação da nova proposta na unidade educacional. A segunda fase começou no final de 2004, quando houve uma revisão dos princípios anteriormente definidos e também da prática desenvolvida no curso da implantação da proposta. É nesta segunda fase, já em 2006, que a investigação empírica surgiu como possibilidade de mais novo movimento para incrementar a prática no âmbito da proposta, contemplando a pesquisa-ação e a tutoria entre pares, conforme melhor explicitado na parte II deste trabalho.

\section{6.1- FASE I: implantação da proposta}

Fruto do acúmulo das discussões iniciadas em 2000, a implantação da proposta pedagógica de Reorganização dos Espaços e das Atividades teve início, no que se refere à reorganização dos espaços e nas alterações efetivas do planejamento e da rotina de trabalho, no segundo semestre de 2003, na EMEI Eurípedes Simões de Paula ${ }^{4}$, partindo da iniciativa e da discussão mais sistemática de 3 educadoras, e da coordenadora pedagógica.

Essas educadoras utilizavam em 3 períodos diferentes do dia, e com 3 agrupamentos distintos, o mesmo espaço físico para as atividades. Cada agrupamento contava com 37 crianças de 6 anos, que permaneciam 4 horas na unidade educacional.

A parceria efetiva dessas 4 profissionais fez com que mudanças significativas fossem realizadas nos espaços internos das salas de atividades, na organização dos materiais e forçaram alterações substanciais na prática educativa que, em última instância, culminaram em mudanças no planejamento, no tipo de mediação do adulto e nas concepções deste sobre ensino-aprendizagem.

\footnotetext{
${ }^{4}$ A configuração mais detalhada desta instituição de educação infantil encontra-se na Parte II deste trabalho.
} 
A proposta de reformulação da prática pedagógica surgiu a partir da detecção de problemas que afligiam essas três educadoras, fruto de observações de suas práticas e que, de diferentes maneiras, geravam algum tipo de angústia pessoal. $\mathrm{Na}$ interlocução da equipe em torno dessas dificuldades revelaram-se problemas comuns, que recebiam de cada uma das educadoras intervenções diferenciadas. Notou-se, porém, que as intervenções para a resolução desses problemas e inquietações individuais passavam, de alguma forma, pela maior autonomia da criança e pela oportunidade dessa criança ser respeitada em seus desejos e necessidades.

As principais dificuldades apontadas à época envolviam: 1) adultocentrismo, fazendo a criança dependente do professor a maior parte do tempo, como para escolha da atividade, seleção e entrega de materiais, para decidir a hora de realizar essa ou aquela tarefa, para saber a hora de ir ao banheiro etc.; 2) elevado tempo de espera ${ }^{5}$, pois eram 37 crianças em cada agrupamento e apenas uma professora; 3 ) atividades pensadas para uma criança hipotética que representasse a "média" da classe: que não fosse lenta e nem rápida demais, nem inteligente demais e nem com grandes dificuldades; 4) desrespeito aos ritmos, capacidades e necessidades individuais; 5) rotina muitas vezes inflexível; 6) exigência da imobilidade da criança durante a maior parte do período em que permanece na unidade educacional; 7) dificuldade da educadora despender a 37 alunos uma atenção individualizada e promover desafios pertinentes ao seu processo de construção de conhecimentos; 8) dificuldade de aliar a crença teórica e o ideal de qualidade que o educador elegia para a educação infantil com a metodologia adotada em sua prática diária.

Diante disso, o grupo, composto por três professoras, decidiu unir seus fazeres, que eram diferenciados dos demais no âmbito da instituição e ousar a proposição de uma nova forma de prática pedagógica na educação infantil no contexto e na realidade em que se encontravam. Tal empreendimento contou com o suporte efetivo e atuação colaborativa da coordenadora pedagógica da unidade.

Para tal, buscaram inspirações em propostas construtivistas que, de alguma maneira, haviam vivenciado durante seu processo profissional ou formativo e que mesmo sem um estudo aprofundado já faziam parte de seu universo de significações. Não havia até então um estudo sistemático ou a explicitação de

\footnotetext{
${ }^{5}$ Definiu-se como tempo de espera o período em que a criança permanecia ociosa, não por vontade própria, mas aguardando a autorização da educadora para realizar determinada ação.
} 
intencionalidade de adaptação de algum modelo pedagógico específico que norteasse a prática desenvolvida por estas educadoras.

Vale lembrar, conforme alerta Zabala (2002 p. 91), que esta ausência de explicitação não configura a inexistência de um referencial teórico norteador das ações. Diz ele que:

[...] Ainda que inconscientemente, sempre se utiliza uma determinada concepção: quando se explica de certa maneira, quando se exige um determinado estudo, quando se propõe um número de conteúdos [...] por trás de todas estas decisões existe uma idéia de como as aprendizagens são produzidas. O mais extraordinário disso tudo está no desconhecimento de que não se utiliza um modelo teórico explícito, também se atua sob um referencial teórico.

Antes da implantação da proposta de Reorganização dos Espaços e das Atividades a sala de atividades tinha a seguinte configuração: 10 mesas, com 4 cadeiras em cada mesa, um painel de cortiça e um varal na parede do fundo da sala, cujos espaços eram reservados à exposição ou secagem das atividades gráficas realizadas pelas crianças, além dos armários das professoras e uma lousa que tomava toda a parede da frente.

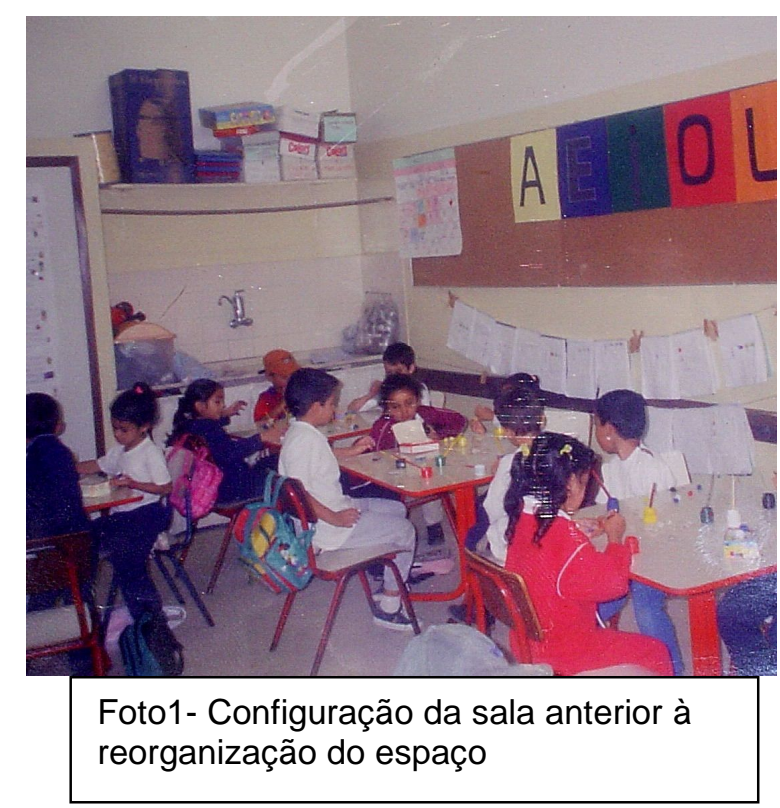

Com a implementação da proposta de trabalho denominada Reorganização dos Espaços e das Atividades, foram efetuadas mudanças no espaço e na rotina da sala de aula: 1) o material de uso pessoal das crianças como lápis, tesoura, cola etc. foi individualizado, colocado em recipientes de fácil acesso e manuseio (potes vazios de sorvete) e deixado à disposição para uso; 2) das dez mesas da sala, foram 
deixadas apenas quatro, sendo três destinadas a atividades de livre escolha das crianças ou propostas pela educadora e uma para utilização em atividades espontâneas de cunho artístico; 3) foi organizado amplo espaço livre no centro da sala, que possibilitou a atividade motora da criança com maior liberdade; 4) as educadoras criaram um acervo de brinquedos, colocado à disposição das crianças em baldes plásticos que não eram utilizados pela equipe de limpeza da unidade educacional; 5) disponibilizou-se materiais de construção, de uso para suporte a jogos simbólicos, jogos pedagógicos de tabuleiro, matemáticos, entre outros; 6) providenciaram-se papéis variados, artigos para colagem, modelagem e pintura; 7) foi instalada uma estante com acervo de literatura infantil e livros variados; 8) disponibilizou-se um rádio gravador com dois fones de ouvido para a reprodução de histórias de áudio 6 .

Em linhas gerais, a sala se encontrava com a seguinte organização espacial:
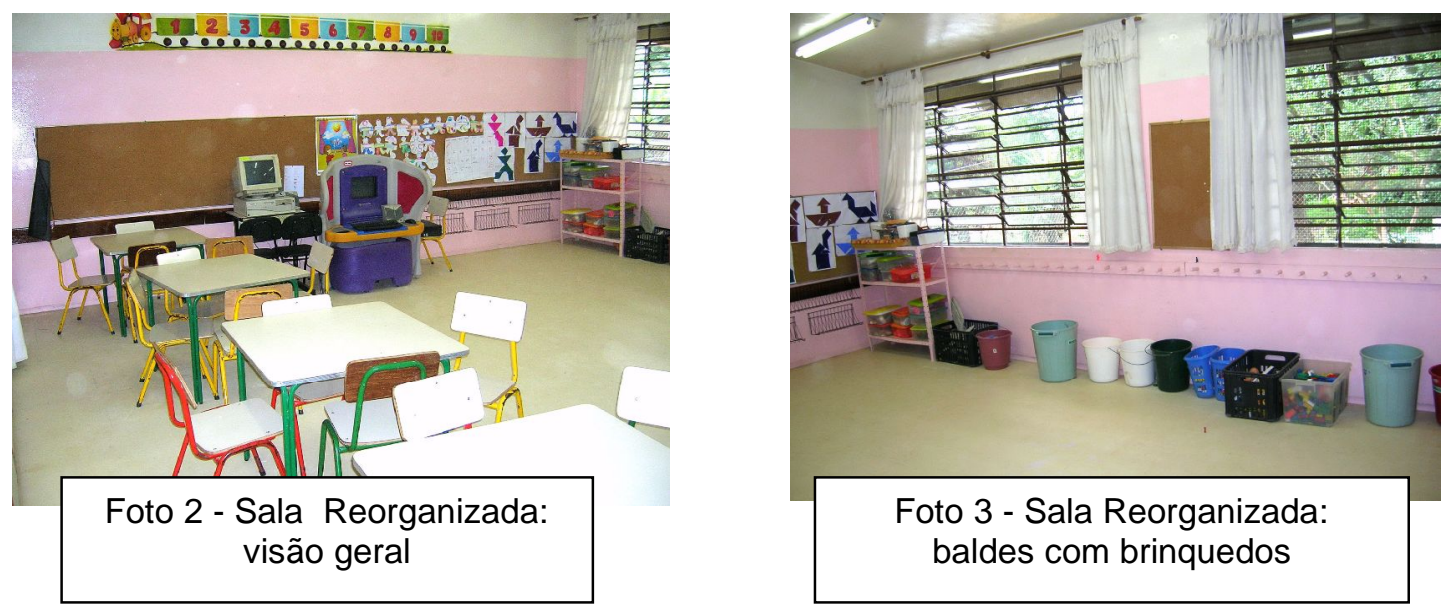

Nesse momento, a maior parte dos materiais disponibilizados era comprado e mantido pelas próprias educadoras, fruto de seu acervo pessoal e disponibilizado para uso das 110 crianças.

No final de 2004, como resultado do projeto AVISALÁ ${ }^{7}$ uma parceria da IBM com a Prefeitura do Município de São Paulo (PMSP), foi instalado um computador com jogos, destinado ao uso das crianças na sala.

\footnotetext{
${ }^{6}$ Outras fotos do arranjo espacial inicial encontram-se na parte II deste trabalho, capítulo 6.

7 Projeto Avisalá. O instituto Avisalá, em parceria com a International Business Machine (IBM do Brasil) , realizou junto a algumas unidades de educação infantil do Município de São Paulo um projeto de inclusão digital das crianças de 4 a 6 anos que freqüentavam a escola pública. A adesão da escola era voluntária e a entrega de um computador para uso das crianças estava vinculada a um processo de formação dos coordenadores pedagógicos que discutia questões relacionadas com os tempos e
} 
A esse tempo não foram formados "cantos" de atividades com separação espacial específica, mas disponibilizaram-se materiais diversos que poderiam formar um ou mais "cantos", de acordo com o interesse do grupo de crianças e por iniciativa própria delas.

O espaço organizado dessa maneira permaneceu até o princípio do ano letivo de 2006, com alterações pontuais de materiais. Não ocorreu, porém, mudança alguma em sua organização.

A rotina de trabalho estava assim configurada na unidade educacional:

1- Trabalho em grande grupo: envolvendo todo o grupo de crianças em atividades como roda de conversa, planejamento do dia, avaliação das atividades realizadas, explicação das atividades individuais propostas pelo professor a partir do projeto da sala, hora da história, jogos e brincadeiras tradicionais etc.

2- Atividades individuais ou em pequenos grupos espontâneos: pequenos grupos que se formam e desfazem de acordo com interesses comuns ou afinidades, sendo organizados pelas crianças por ocasião da brincadeira, tendo duração correspondente ao seu desejo comum, em que a criança opta por determinada atividade, seja ela brincadeira, desenho, pintura, colagem, ou outras, e a realiza com ou sem seus pares.

3- Atividades individuais ou em pequenos grupos orientados: quando a criança faz sua produção sobre o tema relacionado ao projeto de trabalho do agrupamento. Essas atividades são planejadas pela educadora ou pelas crianças no grande grupo e acompanhadas pela educadora durante a realização.

Cada dia contemplava, no mínimo, uma atividade de grande grupo (geralmente duas) e uma atividade de pequeno grupo proposta pela educadora, ocorrida simultaneamente com a atividade livre. $\mathrm{Na}$ atividade livre, com duração diária de uma hora e trinta minutos a criança opta, de acordo com seu interesse, por realizar atividades individualmente ou compor grupos espontâneos, utilizando os diferentes materiais disponíveis. Há ainda na rotina um momento de utilização da área externa (parque), além de momentos para alimentação e higiene.

espaços. Nesta proposta pedagógica orquestrada pelo instituto Avisalá era privilegiado o trabalho com cantinhos, sendo o computador um desses cantos. Cada unidade educacional participante recebia um computador e programas com vários jogos. 
Essa dinâmica do trabalho iniciou-se em 2003 e mantinha-se a mesma durante a fase II da proposta. Contudo, com o passar do tempo transformou-se, tendo incrementados seus objetivos, emprego de materiais e atividades propostas.

\subsection{2 - FASE II: de 2004 à época da pesquisa}

A partir do final de 2004, em vista do que se tinha anteriormente, a concepção de criança e dos objetivos da educação infantil já se encontrava alterada e iniciou-se nova etapa na proposta de Reorganização dos Espaços e das Atividades. O intuito era valorizar cada vez mais o protagonismo da criança e a cultura da infância, dentro das condições e possibilidades físicas e de recursos humanos da unidade escolar.

Embora apenas uma das cinco salas estivesse totalmente com seus espaços reorganizados em 2004, outros educadores aderiram à proposta. Dos dezesseis agrupamentos, seis aderiram de forma integral à proposta e três de forma parcial, seja em espaços parcialmente reorganizados ou em espaços ainda inalterados.

Em 2006, três das cinco salas estavam com espaços reorganizados e equipadas com materiais disponíveis na unidade educacional. Outros foram adquiridos pelos próprios professores e também comprados a partir da verba arrecadada junto às famílias ou aos órgãos da Secretaria de Educação. Na ocasião do estudo empírico, nove dos dezesseis agrupamentos ocupavam salas com completa reorganização de espaços e atividades e as demais estavam parcialmente modificadas em seu espaço, porém sem adesão completa das educadoras à proposta que já havia, nessa época, adquirido o status de projeto pedagógico da unidade.

As alterações nos espaços tiveram especial atenção nesta proposta, porém foram diferenciadas as opções pessoais de organização efetivadas pelas educadoras, de acordo com suas concepções de criança e de educação e decorrentes ainda das dinâmicas das relações interpessoais valorizadas junto às crianças. 
Relatos de educadoras mais antigas na unidade educacional ${ }^{8}$ apontam que no início do trabalho o uso de espaços e materiais comuns às educadoras e às 120 crianças em cada uma das salas (diariamente) gerou inúmeros problemas, necessidades de acordos e intervenções que atingiram toda a unidade educacional. Esses embates nem sempre tiveram desfechos definitivos que levassem à resolução das dificuldades enfrentadas.

Notou-se, durante a realização do estudo empírico em 2006, que as discussões entre as educadoras envolvidas no processo de implementação da proposta remetiam já a outras questões, abordando prioritariamente a escolha dos materiais que poderiam ser disponibilizados às crianças e os objetivos dos mesmos, sem a necessidade de deter-se mais demoradamente nos problemas relacionados ao manuseio, à organização ou conservação.

Cabe aqui uma consideração sobre o momento de avaliação ocorrido no início de 2006, antes do início deste estudo, quando as educadoras reavaliaram a implementação da proposta de reorganização na unidade educacional. Para algumas educadoras os pressupostos que guiaram essas modificações na prática pedagógica estavam pouco claros, o que foi gerando visões diferenciadas sobre os reais objetivos da introdução da brincadeira no espaço da sala de aula, sobre o papel do professor nessa dinâmica e sobre a eleição da autonomia e o protagonismo da criança como objetivos norteadores da prática 9 .

Um dos temores das educadoras era que o "brincar pelo brincar", como ação ligada apenas ao prazer da criança, assumisse papel preponderante na educação infantil realizada e fosse deixado de lado o papel imprescindível do professor como facilitador da construção de conhecimentos significativos pelas crianças. A avaliação do trabalho realizado no primeiro semestre de 2006 pelos educadores da unidade apontou a necessidade de um processo de reflexão mais profundo e efetivo, o que pretendiam promover a partir de agosto de 2006 , de maneira mais sistemática e contextualizada, incorporando avaliação da prática com estudos teóricos.

\footnotetext{
${ }^{8}$ São relatos informais, fruto de conversas ocasionais entre educadoras e a pesquisadora, que ocorreram de maneira assistemática em alguns intervalos de tempo durante sua permanência na unidade educacional.

${ }^{9}$ Informação verbal, coletada durante as discussões efetivas na reunião pedagógica da unidade educacional realizada em 2/2/06.
} 
Essa discussão não ocorreu efetivamente, ficando a busca de subsídios e material de apoio teórico vinculada e circunscrita às ações particulares de cada educadora.

A intermediação da coordenadora pedagógica, que no início da implantação da proposta era marcante, sofreu uma interrupção devido a sua transferência para outra unidade educacional ${ }^{10}$.

No ano da realização da pesquisa, uma nova coordenadora pedagógica inicia seu trabalho na unidade educacional e devido ao desconhecimento do processo inicial de implantação da proposta e pela necessidade de criar e fortalecer vínculos com as educadoras, houve um movimento diferenciado na unidade educacional: as discussões sobre o trabalho pedagógico ficaram menos evidentes e as contribuições se mostraram mais tímidas.

Nos últimos tempos de 2006, quando era finalizada a coleta de dados deste estudo empírico, a educadora que teve sua prática acompanhada apontou que essa dificuldade de interlocução sobre o trabalho desenvolvido, tanto com a coordenadora, como com seus pares, ainda era uma realidade e em vários momentos interferia negativamente em suas ações ou resultados alcançados ${ }^{11}$.

No decorrer do processo presenciado pela pesquisa, ficou claro que o grupo de educadoras ainda não estava coeso na tentativa de alcançar objetivos comuns. Contudo, havia evidências de que, paulatinamente, instalava-se uma concepção de criança e de educação completamente diferenciada da visão preparatória que ali era preponderante em tempos anteriores. Notava-se um esforço por interpretar a realidade com vistas à implementação de uma proposta de trabalho mais perene, coerente e única para orientar a ação de todas educadoras da unidade.

\footnotetext{
${ }^{10}$ A Lei no 11.229/92 que dispõe sobre o Estatuto do Magistério Municipal de São Paulo, em seu capítulo $\mathrm{V}$, artigos 45 a 49, dá orientações sobre o processo de transferência de unidade de trabalho para prestação de serviços dos integrantes da carreira do magistério. Essa lei afirma que a remoção é o deslocamento dos integrantes do quadro do magistério, que ocorre anualmente e quando os profissionais podem remover-se de suas unidades de trabalho por concurso ou por permuta. Para tanto, há classificação prévia onde é computado o tempo de trabalho do profissional na carreira do magistério.

${ }^{11} \mathrm{Na}$ Parte II, quando forem tratados os dados relativos ao Eixo 2, relacionados ao acompanhamento da prática pedagógica, haverá maiores esclarecimentos sobre essas análises da educadora.
} 
CAPÍTULO 2

O BRINCAR NA EDUCAÇÃO DA CRIANÇA PEQUENA 
Neste capítulo pretende-se pontuar alguns aspectos históricos relativos à constituição do conceito de brincar, identificando como essa atividade tem sido compreendida no âmbito de modelos e propostas pedagógicas para a educação da infância. Destaque especial será dado à concepção do brincar nas especificações teórico-práticas endereçadas aos CEls e EMEIs ${ }^{12}$ do Município de São Paulo e,

particularmente, como a brincadeira é concebida no interior da proposta de

Reorganização dos Espaços e das Atividades, implantada na EMEI Eurípedes Simões de Paula e estudada neste trabalho.

A legitimação do valor da brincadeira não segue os mesmos padrões em diferentes contextos. As várias concepções do brincar na infância e, em especial, na educação infantil correspondem a concepções de infância, de criança e de educação, assim como, numa esfera mais abrangente, a dados conteúdos culturais, pertinentes a espaços e tempos históricos particulares.

A Constituição Federal de 1988 e a Lei de Diretrizes e Bases da Educação Nacional n 9394 de 1996 (LDBEN) brasileiras definem a educação básica como direito da criança, compreendendo as modalidades: educação infantil, com atendimento de zero a seis anos, o ensino fundamental e o ensino médio. O brincar como direito da criança está presente em vários dispositivos legais, dentre eles, as Diretrizes Curriculares Nacionais para a Educação Infantil (DCNEl/99, Parecer CEB/CNE 22/98, aprovado em 17/12/98), que atribui à educação infantil o compromisso de garantir o desenvolvimento da criança também na dimensão lúdica, ao dizer que o processo educativo deve considerar as crianças em sua totalidade, as diferenças entre elas e sua forma privilegiada de conhecer o mundo pelo brincar.

O Brasil também é signatário de convenções internacionais como a Declaração Universal dos Direitos da Criança (Organização das Nações Unidas, ONU 20/11/1959), que visa garantir a proposição de que '[...] a criança terá ampla oportunidade para brincar e divertir-se visando os propósitos mesmos de sua educação; a sociedade e as autoridades públicas empenhar-se-ão em promover o gozo desse direito".

Essa legitimação do brincar como direito é conseqüência das concepções de infância, criança e educação presentes na atualidade e que se revelam na

\footnotetext{
${ }^{12}$ CEI - Centro de Educação Infantil, de administração direta da Prefeitura do Município de São Paulo.
} 
preocupação crescente dos diferentes setores da sociedade com o desenvolvimento integral da criança, seu processo de aprendizagem e desenvolvimento.

Embora o direito a brincar esteja garantido na legislação e componha os discursos de legisladores e profissionais da educação, na esfera do cotidiano infantil a brincadeira nem sempre está presente. Esse reduzido espaço do brincar na infância brasileira ocorre em conseqüência de diferentes circunstâncias: restrições sócio-econômicas da família, que conduzem a criança à realização de atividades adultas (trabalho infantil); valorização exacerbada da antecipação da escolaridade e do preparo para a alfabetização e limites de espaços e tempos impostos à criança pela condição de vida, sobretudo em metrópoles como a cidade São Paulo.

\subsection{Trajetória evolutiva do jogo}

Ao longo dos tempos, a brincadeira despertou o interesse de estudiosos de diferentes campos do conhecimento - filósofos, historiadores, psicólogos, antropólogos, sociólogos e pedagogos. Entre eles é imprescindível citar Caillois (1967), Huizinga (1987), Elkonin (1988), Winnicott (1975), Benjamin (2005), entre outros.

Brougère (2003) analisa as origens do jogo e volta à tradição etrusca, em que prevalecia a idéia do fingimento, o como se. Em Roma, com influência desta perspectiva, os jogos apresentavam-se ligados a religiosidade, muitas vezes enunciados como forma de poder e utilizados para fins políticos. Não havia periodicidade regular para sua realização.

$\mathrm{Na}$ Grécia já havia outra configuração. Os jogos e concursos eram instrumentos de integração, harmonia e consenso da comunidade, além de manterem a perspectiva de ligação com o divino. Como no jogo romano, havia o "como se", mas a simulação existia mais para afrontar o outro do que proporcionar prazer ao espectador.

O jogo grego pode ser, segundo o autor, dividido em duas partes: 1) jogos de cena compostos pelo teatro, mímica, dança e concursos de poesia; 2) jogos de circo, compostos por corridas de biga, combates e encenações com animais, caças e jogos atléticos. Em 776 a.C. instaura-se na Grécia a prática da realização dos Jogos Olímpicos (Ibidem). 
Por longo tempo o jogo fica ainda limitado à recreação, ao relaxamento necessário às atividades que exigem esforços físicos, intelectuais ou escolares. São representantes desta fase pensadores como Sócrates, Aristóteles, Sêneca e Tomás de Aquino (Kishimoto, 1988).

$\mathrm{Na}$ Idade Média o jogo afasta-se pouco a pouco da religiosidade e começa a surgir a separação entre jogo, festa e outras atividades da vida social. O jogo passa a representar a frivolidade e a futilidade.

O Renascimento vê a brincadeira como conduta livre, que favorece o desenvolvimento da inteligência e facilita os estudos, sendo adotada como contraposição aos processos verbalistas vigentes. Comungam desta perspectiva Quintiliano, Erasmo, Rabelais e Basedow (Ibidem).

No século XVIII, com o avanço dos jogos de azar, o prazer derivado do jogo passa a ser visto como um mal para a sociedade. As discussões em torno do jogo têm foco na perspectiva do vício e de seus efeitos, não havendo, ainda, a valorização dos jogos infantis. Brougère (2003) ressalta que o período anterior ao Romantismo, com predominante visão Cristã, foi caracterizado pela concepção de uma criança marcada pelo pecado original, sem valores positivos e, portanto, a pedagogia decorrente dessa crença era baseada na vigilância, que desvaloriza a espontaneidade e a expressão da criança. Decorre disso, a ausência de valorização dos seus jogos e demais atividades espontâneas.

Com Rousseau (1712-1778) a educação da criança está baseada no mito do bom selvagem, a infância é valorizada e considerada não corrompida. A educação propõe uma preservação da natureza do indivíduo nas questões relacionadas à liberdade para se desenvolver. O jogo é instrumento de ensino e um suporte de sedução, proposto para garantir a motivação da criança para aprendizagem de conteúdos adequados a sua idade. O jogo espontâneo não merece, nesse momento, maior atenção ou valorização. Está em voga, sua finalidade educativa (instrutiva).

O Romantismo vem fixar a idéia, nascida no Renascimento, da criança dotada de valor positivo, que se expressa por meio do jogo, sendo este então, considerado como uma conduta típica da criança (Kishimoto, 1988).

Vale ressaltar que a partir de Comenio, Rousseau e Pestalozzi surge um novo sentimento sobre a infância, objetivando protege-la e dar-lhe estatuto de categoria social. Inicia-se a criação de métodos para ensinar a criança em casa e 
nas instituições. Nessa fase tem-se uma concepção idealista e protetora da infância. $\mathrm{Na}$ França, as idéias de Rousseau permitiram a criação de vários brinquedos educativos utilizando princípios da educação sensorial, inicialmente para crianças deficientes e depois estendida às demais (Wajskop, 2001).

Os postulados de Rousseau e Pestalozzi foram sucedidos pelas idéias de Froebel, que retomam os temas filosóficos do Romantismo e colocam o jogo e certos brinquedos no centro da educação da primeira infância. O jogo vem romper com a frivolidade e situa-se no lado sério, como expressão, juntamente com a palavra, da riqueza interior da criança. A valorização do jogo decorre da valorização da infância, a criança deixa de ser um adulto em miniatura para transformar-se em um adulto em germinação, sendo a infância o tempo no qual o indivíduo estabelece as bases de seu caráter (Brougère, 2003).

Embora não tenha sido o primeiro a analisar o valor educativo do jogo, Froebel foi o primeiro a colocá-lo como parte essencial do trabalho pedagógico, ao criar o Jardim de Infância, com o uso de jogos e brincadeiras no processo educativo (Kishimoto, 1988).

Froebel, por meio de seus brinquedos e dons, cria o espaço para a criança ter iniciativa, expressar sua fala, representar seu imaginário. Ele aponta a capacidade simbólica da criança, enfatizando que a mesma cria significações a partir dos objetos de seu mundo. Propõe ainda o uso dos materiais, tanto em atividades livres quanto orientadas; parece, porém, que esta perspectiva foi pouco compreendida pelos educadores da época (Ibidem).

Mais tarde, vieram Maria Montessori e Ovide Decroly que, como pedagogos, trouxeram novas referências à educação pré-escolar, com o rompimento da educação verbal e tradicionalista da época e propondo a educação sensorial baseada em jogos e materiais didáticos.

Nesse período da história da Pedagogia, é crescente o respeito pela atividade da criança, mas a concepção de educação é baseada em uma ação cumulativa e progressional do conhecimento a partir da exploração empírica da realidade (do simples para o complexo, do concreto para o abstrato) e tudo nesses métodos sugere que o treino leva ao conhecimento e controle corporal. A linguagem é concebida como um código lingüístico de comunicação e não como sistema de representação, vindo daí a utilização do método fonético e dos exercícios mecânicos de treino visual, auditivo e memória (Wajskop, 1995). 
Freinet, que é a favor dos métodos naturais, da livre expressão e da pesquisa experimental, considera "que a criança não brinca gratuitamente, e o que aparenta ser uma atividade puramente lúdica é, na verdade, um trabalho dos mais sérios" (Elias e Sanches, 2007, p. 161).

O jogo é, para Freinet, o verdadeiro trabalho da criança, colaborando com seu desenvolvimento social. $O$ trabalho-jogo torna-se, desta maneira, a base do processo educativo nos primeiros anos da infância (Elias e Sanches, 2007).

Os estudos da psicologia e da sociologia acrescentaram importantes elementos à compreensão da atividade do brincar.

A Pedagogia dos séculos $X X$ e início do século $X X I$ e, especialmente as teorizações sobre o brincar no campo da educação, são tributárias dos enunciados relacionados aos modelos pedagógicos que foram sendo desenvolvidos e posteriormente contextualizados no âmbito dos diferentes sistemas de ensino ou das próprias unidades educacionais.

Cada vez mais a brincadeira é alvo de discussões dos teóricos e dos educadores de infância e, embora a valorização desta atividade seja atualmente praticamente um consenso, nota-se, porém, que assume objetivos díspares se comparados os diferentes contextos culturais e sociais nos quais se apresenta.

\subsection{Conceito de jogo e de brincadeira}

No Brasil, assim como em outros países, a história dos modelos pedagógicos destinados à educação da criança pequena revela o aparecimento da infância como categoria social diferenciada do adulto em função da sua brincadeira. Todavia, a relação entre brincadeira e educação não é constante, nem tem nos diferentes contextos sociais a mesma configuração. $O$ papel atribuído à brincadeira, tanto quanto os termos que se remetem a ela, variam não só de lugar para lugar, como também de época para época.

Segundo Kishimoto (2003, p. 17) empregar um termo não é um ato solitário. Subentende todo um grupo social que o compreende, fala e pensa da mesma forma. O brincar é um termo polissêmico, atrelado a um dado momento histórico, a um panorama cultural mais amplo. A autora afirma que no Brasil há baixa conceitualização, sendo os termos jogo, brinquedo e brincadeira, utilizados 
indistintamente, ora como sinônimos, ora com conotações completamente diversas, dependendo nesses casos do autor que deles se utiliza.

Devido a essas considerações, buscar-se-á esclarecer o que está sendo compreendido neste relato de pesquisa quando houver utilização dos termos brincadeira, jogo e brinquedo.

Brougère (2003) utiliza o termo jogo como sinônimo de brincadeira. Afirma que o jogo é resultado de relações interindividuais e, portanto, de cultura. Nessa perspectiva, o jogo pressupõe aprendizagem social, não sendo um comportamento específico, mas uma situação na qual esse comportamento adquire um significado específico para seus membros.

O autor arrola algumas características que separam o jogo das demais atividades infantis. São elas: 1) livre escolha; 2) decisão de entrar no jogo e também de definir seus acontecimentos; 3) sistema de sucessivas decisões expresso através de um conjunto de regras que é partilhável ou partilhado com os outros; 4) comportamento não literal, dissociado de suas conseqüências normais; 5) presença da situação imaginária; 6) pouca possibilidade de controle do exterior, sendo marcado pelo aberto e o incerto; e 7) processo significativo de exploração e ação que prevaleça sobre os resultados esperados (ibidem).

Quanto ao protagonismo da criança, Brougère (2004) afirma que a presença de brinquedos no ambiente não é capaz de impor-se na brincadeira sem que haja uma decisão primeira de quem brinca, de vir a interagir com eles. Só há brincadeira quando existe essa intenção por parte da criança. A brincadeira, segundo o autor, pode ainda acontecer mesmo sem qualquer tipo de apoio material.

Tendo em vista as características da brincadeira apontadas por Kishimoto (2003) e Brougère (2003), o presente trabalho define como brincadeira livre qualquer atividade da criança que: seja resultado de sua livre escolha; envolva regras por ela determinadas; derive de um processo de sucessivas decisões; esteja desvinculado de fins específicos externamente orientados e a levem a exercitar o protagonismo nas ações.

Nessa perspectiva, as atividades de: pintura, modelagem, uso do computador, desenho, dentre outras, podem juntar-se à brincadeira de faz-de-conta no rol das situações definidas como brincadeira, desde que contemplem as condições anteriormente mencionadas. Dessa forma, constituir-se-ão momentos mais 
convenientes ao acompanhamento, observação e coleta de dados para análise do envolvimento das crianças durante suas atividades na sala reorganizada ${ }^{13}$.

Referindo-se aos jogos estruturados, considerados como material pedagógico, Kishimoto (1996) afirma que aos brinquedos educativos podem ser atribuídas duas funções: uma lúdica, na qual o brinquedo propicia diversão, prazer e até desprazer quando escolhido voluntariamente pela criança; e uma função educativa, em que o brinquedo ensina algo que compete ao indivíduo saber, objetivando ampliar seus conhecimentos e sua compreensão de mundo. A autora afirma que, apesar da riqueza de situações de aprendizagem que o jogo propicia, nunca se tem a certeza de que a criança construirá o conhecimento exatamente da forma desejada por quem o disponibilizou.

Neste estudo empírico realizou-se o acompanhamento da criança envolvida com diferentes jogos estruturados e, levando em conta o referencial teórico mencionado, optamos por classificar os jogos nos quais a criança se envolveu por vontade própria como fazendo parte de suas experiências de brincadeira, e aqueles no qual houve uma participação obrigatória da criança ou planejamento da ação pela educadora e para o qual havia sido estabelecido algum objetivo específico de ensino, como fazendo parte do rol de atividades orientadas e, portanto, classificadas como não-brincadeiras.

Em síntese, o mesmo material pode ter recebido diferentes classificações de acordo com o uso que dele foi feito, visto considerar-se que a ação exercida é preponderante ao objeto em si nesta análise.

Esta opção de prevalência da ação sobre o objeto é apontada por Brougère (1994), que vai esclarecer que a criança brinca com substâncias materiais e imateriais que lhe são propostas. Segundo o autor, os brinquedos orientam a brincadeira, trazendo-Ihe matéria, mas não a condicionam. Para ele, só se pode brincar com o que se tem, entretanto a criatividade e a imaginação permitem ultrapassar esse ambiente e esse material, que são por si mesmos sempre particulares e limitados.

O brincar da criança está vinculado a um contexto social maior, sendo influenciado por fatores externos como: brinquedos e materiais disponíveis; ambiente; atitudes dos indivíduos que com ela interagem; capacidades individuais;

\footnotetext{
${ }^{13}$ Maiores esclarecimentos sobre a coleta de dados e seus resultados encontram-se parte II deste trabalho, quando se tratará dos procedimentos de pesquisa.
} 
meio social; cultura e imagens veiculadas pela sociedade. Esse conjunto de fatores interligados complexamente presentes no brincar, é definido por Brougère (1994, p. 50) como cultura lúdica, considerando-a como:

[...] uma estrutura complexa e hierarquizada, constituída (essa lista está longe de ser exaustiva) de brincadeiras conhecidas e disponíveis, de costumes lúdicos, de brincadeiras individuais, tradicionais (se isso pode ter sentido) ou geracionais (próprio de uma geração específica).

Brougère (1994) afirma que a sociedade vai fornecer elementos que vão compor a cultura lúdica da criança, mas essa construção será completamente singular para cada uma, de acordo com as relações que ela estabelecer com os outros indivíduos, com os materiais concretos e com a herança cultural do próprio contexto. Ressalta, ainda, que nem tudo que é identificado como brincar pelo adulto o é para a criança e que na brincadeira o imaginário pode prevalecer, desconsiderando ou suplantando a realidade objetal como a oferta de materiais ou o ambiente.

Essas proposições levam a considerar o brincar como atividade contextualizada culturalmente, que aparece na educação atrelada a concepções que os educadores têm de criança, desenvolvimento, aprendizagem e também dos objetivos que estes elegem para a educação infantil.

Os modelos pedagógicos voltados à educação da criança pequena têm seu lugar num dado momento histórico e cultural, trazendo, portanto, concepções que norteiam a construção e a efetivação das ações que estes propõem. Deriva disso que o mesmo aspecto toma diferentes dimensões e pode possuir diferentes propósitos em cada proposta específica.

\subsection{Teorizações da Psicologia socioconstrutivista sobre a brincadeira}

Valorizar a brincadeira da criança pequena, pensando-a como propulsora de aprendizagens significativas e, portanto, do desenvolvimento, tem respaldo na teoria histórico-cultural.

A perspectiva histórico-cultural pressupõe que o desenvolvimento ocorre a partir das interações que o indivíduo faz, ao longo da vida, com parceiros diversos, em práticas sociais concretas. Os parceiros de interação constituem-se 
reciprocamente como sujeitos no processo de negociar significados de eventos, coisas, pessoas, lugares e sentimentos (Rossetti-Ferreira 2004)

Nesse sentido, a interação com parceiros mais experientes torna-se fundamental. Vygotsky (2003a, p. 114) afirma que todas as funções cognitivas aparecem duas vezes no desenvolvimento cultural da criança: primeiro, no nível social, nas atividades coletivas partilhadas pelo o indivíduo e seu grupo social (interpsicologicamente) e mais tarde como propriedades internas do pensamento da criança (intrapsicologicamente). Essa transformação do processo interpessoal em intrapessoal é resultado de uma longa série de eventos de desenvolvimento, sendo particular e específica para cada indivíduo.

Ressalta também Oliveira, M. K. (1992b) que cada indivíduo é absolutamente único e por meio de seus processos psicológicos mais sofisticados (que envolvem consciência, vontade e intenção) constrói seus significados e recria sua própria cultura. Propõe ainda a unidade entre os aspectos intelectuais e volitivo/afetivos, enfatizando que o pensamento origina-se na esfera da motivação (que inclui inclinações, necessidades, interesses, afeto e emoção). Assim, a essência da psique humana é constituída por uma inter-relação dinâmica, em transformação ao longo do desenvolvimento, entre intelecto e afeto, atividade no mundo e representação simbólica, controle dos próprios processos psicológicos, subjetividade e interação social.

$\mathrm{Na}$ perspectiva histórico-cultural desenvolvimento e aprendizagem, embora inter-relacionados, são diferentes. A aprendizagem antecede o desenvolvimento e esse influencia a aprendizagem futura, mas existe uma assintonia neste processo.

Vygotsky (2000, pp. 109-113) propõe que existem dois níveis de desenvolvimento, o nível de desenvolvimento real é o que se estabelece como resultado de desenvolvimentos das funções mentais já completados e no qual a criança consegue resolver por si mesma os problemas, caracterizando 0 desenvolvimento mental, neste caso, retrospectivamente. O nível de desenvolvimento potencial define as funções que amadurecerão, mas que estão em estado embrionário, sendo caracterizado pelo desenvolvimento que se refere à solução de problemas, só possível quando a criança está sob a orientação de um adulto ou de companheiros mais capazes, caracterizando o desenvolvimento mental, neste caso, prospectivamente. 
A Zona de Desenvolvimento Proximal (ZDP) caracteriza-se pela distância entre o nível atual que a criança tem para resolver por si mesma os problemas e o nível de desenvolvimento potencial, determinado pela capacidade de resolução da criança intermediada por parceiros mais capazes, mais avançados (lbidem).

Fino (2001), reportando-se à teoria histórico-cultural da atividade, afirma que Vygotsky considera a atividade como condição precedente do conhecimento, mediada por signos culturais como linguagem, uso de utensílios, tecnologia e meios de comunicação, entre outros, e que as próprias tecnologias são artefatos da atividade prática. Portanto, à medida que esses artefatos mudam, muda também a atividade e com ela a consciência dos participantes, num continuum que envolve ciclos de aprendizagem.

Oliveira, M. K. (1992 b) reforça isso dizendo que o homem não tem acesso direto aos objetos, fatos etc. O acesso é sempre mediado e que uma forma de mediação é o processo de representação mental. É a operação com esses sistemas simbólicos que permite a realização de formas de pensamento que não seriam possíveis em termos só perceptuais concretos e que vão, portanto, definir o salto para os processos psicológicos superiores.

Nesse processo de internalização dos conteúdos socialmente aprendidos 0 indivíduo deixa de se basear em signos externos e começa a apoiar-se em recursos internos, como a representação mental dos objetos e os conceitos já construídos. Essa internalização pode ocorrer de diferentes maneiras e na criança a brincadeira é o principal caminho para tal desenvolvimento.

Vygotsky (2000) assinala que a brincadeira não é uma cópia da atividade mental da criança. Na brincadeira a ação encontra-se subordinada ao significado, enquanto na vida real é a ação que predomina sobre o significado. Pela perspectiva do autor, é na brincadeira que a criança aprende a agir numa esfera cognitiva em vez de apenas visual e externa. São as motivações intrínsecas que predominam nessa atividade e a brincadeira provê então uma situação de transição entre a ação da criança com objetos concretos e suas ações com significados.

Para Vygotsky (2003b, p. 105)

[...] só existe brincadeira a partir de uma situação imaginária e a imaginação representa uma forma especificamente humana de atividade consciente, que não é encontrada nem nos animais e nem nas crianças muito pequenas. $\mathrm{Na}$ brincadeira a criança age de uma forma mais avançada que nas atividades da vida real e também aprende a separar objeto e significado... quando a criança 
brinca com bonecas, a menina não aprende a cuidar de uma criança viva, mas a sentir-se mãe.

Em relação ao jogo simbólico, afirma que a experiência futura vai além do preparo para a atividade que a criança vai realizar, pois nenhum jogo é cópia do anterior, já que a criança está imersa num universo de interações que se coordenam e são limitados pelas ações de outros jogadores.

Leontiev (2003) ressalta também que a brincadeira não é a atividade principal da criança no que se refere à predominância do tempo a ela destinado, mas sim por ser esta a atividade em que ocorrem as mais importantes mudanças no desenvolvimento psíquico, sendo ainda a atividade que prepara para novos e mais elevados níveis de desenvolvimento.

Ao considerar que toda a brincadeira tem regras, Vygotsky (2003 b) enfatiza serem justamente essas regras as que possibilitam à criança a internalização de saberes que estão no âmbito do social. Na brincadeira a criança é submetida a condições que se modificam e renovam constantemente, obrigando-a a diversificar, de forma ilimitada, a coordenação social de seus movimentos e the ensinando flexibilidade, plasticidade e aptidão criativa como em nenhum outro âmbito da educação.

A brincadeira exige diálogo, cooperação, troca de informações, acordo sobre regras, disposição para colocar-se na situação imaginária. Inclui a divisão de tarefas e a perspectiva de lidar com o confronto de idéias. Promove a interação, não a interação "lado a lado", mas a troca efetiva de significados e aí se encontra seu grande potencial para gerar aprendizagem e desenvolvimento.

Defender a existência regular da brincadeira na escola de educação infantil pode ganhar mais força quando se pensa ser ela capaz de promover interações significativas entre as crianças. Repartir os significados atribuídos ao vivido torna a criança capaz de reconstruir e reelaborar os significados que lhe foram transmitidos pelo grupo cultural e, neste processo, encontra-se a base da recriação da cultura por parte de cada um dos indivíduos humanos.

A partilha de significados que se faz necessária para o brincar coletivo acontecer é motor de aprendizagens e desenvolvimento, visto confrontar a criança com suas próprias possibilidades psicológicas em detrimento das possibilidades psicológicas dos demais membros do grupo. Este confronto de saberes acumulados 
vai gerar esforços de compreensão que mobilizarão as funções psicológicas em direção ao seu aprimoramento.

Vygotsky (1991, 2000, 2003a, 2003b) faz referências ao que entende por "bom ensino". O argumento de Vygotsky é que, sendo o desenvolvimento atual referente ao que já foi aprendido, o "bom ensino" só poderá ser assim considerado quando desperta e põe em marcha funções que estão em processo, ou seja, quando a educação atua na ZDP da criança, pois aí estará propiciando realmente saltos cognitivos.

Oliveira, M. K. (2001 p. 67) enfatiza que tanto pela criação de uma situação imaginária, como pela definição de regras específicas, o brinquedo cria uma zona de desenvolvimento proximal na criança. No brinquedo ${ }^{14}$ a criança comporta-se de forma mais avançada que nas atividades da vida real e também aprende a separar objeto de significado.

Fino (2001) afirma que ensinar um grupo de crianças onde as ZDPs apenas se sobrepõem parcialmente exige do professor estratégias adequadas, que podem ser baseadas nas interações inter-pares. Não é a instrução em si, mas é a assistência que permite ao aprendiz atuar no limite de seu potencial.

Nessa mesma direção, Oliveira, M. K. (2001, p. 62) afirma que

[...] os procedimentos regulares que ocorrem na escola - demonstração, assistência, fornecimento de pistas, instruções - são fundamentais na promoção do "bom ensino". Isto é, a criança não tem condições de percorrer, sozinha, o caminho do aprendizado. A intervenção de outras pessoas - que no caso específico da escola são o professor e as demais crianças - é fundamental para a promoção do desenvolvimento do indivíduo.

Onrubia (2002) aponta que a interação cooperativa entre os pares pode ser, sob certas condições, favorecedora de aprendizagens através da criação da ZDP. Alguns aspectos seriam relevantes para tal, como a explicitação do próprio ponto de vista, a negociação e o contraste entre pontos de vista moderadamente divergentes a propósito de uma tarefa ou conteúdo de resolução conjunta, a coordenação de papéis, o controle mútuo do trabalho e o oferecimento e recepção mútuas de ajuda. Com essas considerações do autor nota-se como a brincadeira terá lugar privilegiado na educação infantil, justamente por ser a atividade que mais exige a

\footnotetext{
${ }^{14}$ Oliveira (2001) utiliza em seu texto o termo brinquedo como sinônimo de brincadeira, não se referindo ao objeto em si ,mas à ação de brincar.
} 
partilha de conteúdos sociais e de fazeres conjuntos nesse período de vida da criança.

Vygotsky, esclarecendo a correlação existente entre brincadeira e desenvolvimento, vem afirmar:

[...] O brinquedo fornece ampla estrutura básica para mudanças das necessidades e da consciência. A ação na esfera imaginativa, numa situação imaginária, a criação das intenções voluntárias e a formação dos planos da vida real e motivações volitivas - tudo aparece no brinquedo, que se constitui, assim, no mais alto nível de desenvolvimento pré-escolar. A criança desenvolve-se, essencialmente, através da atividade do brinquedo. Somente neste sentido o brinquedo pode ser considerado uma atividade condutora que determina o desenvolvimento da criança (Vygotsky, 2002, p. 135).

Os pressupostos da teoria histórico-cultural serviram como ponto de partida para a proposição da presente pesquisa e ainda como fonte teórica que subsidiou a análise das práticas desenvolvidas na unidade educacional acompanhada. A opção por esse referencial teórico como explicação para o processo de desenvolvimento infantil vincula-se, assim, à hipótese de que a intervenção progressiva e consciente da educadora numa prática pedagógica que valoriza a brincadeira e tem como objetivo ampliar o envolvimento das crianças é capaz de atuar na ZDP dessas crianças e possibilitar maior desenvolvimento e melhoria da qualidade da educação infantil oferecida.

Na perspectiva apresentada, para pensar em qualidade em educação infantil fazse necessária uma análise do papel atribuído à brincadeira em cada modelo pedagógico analisado neste trabalho, constantes no capítulo anterior.

\subsection{A brincadeira no Modelo Pedagógico High Scope}

$\mathrm{Na}$ abordagem High Scope, a prioridade é o desenvolvimento psicológico da criança e o objetivo é propor a ela maior ação, maior iniciativa e maior poder de decisão nas atividades que realiza. Sinaliza Oliveira-Formosinho (1998) que a intervenção desafiadora do adulto é um meio para que a criança possa ampliar seu repertório de possibilidades de ações e aprendizagens.

Nessa abordagem, o brincar é visto como característico da primeira infância e como motor de motivações que possibilitem à criança a realização de atividades 
potencialmente capazes de levá-la ao progressivo desenvolvimento de suas capacidades.

Nesse modelo a brincadeira tem uma rotina previamente estabelecida e é favorecida tanto pela organização do espaço físico e de materiais fornecidos pelo educador (áreas de construção, de casinha, de médico, externa de recreio e outras criadas para atender os interesses das crianças), quanto pela previsão do tempo para esse tipo de atividade (pequenos e grandes grupos, individual, em duplas, recreio) e ainda pela proposta do educador de organizar um ambiente educacional com oportunidades de protagonismo da criança, onde o adulto pode assumir papel menos diretivo, mais de apoio e suporte à atividade da criança.

Em relação à brincadeira, Kishimoto (2001) tece uma crítica ao modelo High Scope, enfatizando que a proposta possibilita a brincadeira livre da criança com tempo, espaço e materiais para brincar. Contudo, na dinâmica de PLANEJAR/FAZER/REVER da brincadeira a obrigatoriedade e rigidez do planejamento pela criança antes do início da atividade seria incoerente com a proposta da brincadeira livre.

Para a autora, os temas e processos de brincadeira surgem e se desenvolvem num contexto lúdico que é mutante e geralmente nem o próprio sujeito que brinca pode explicitar os motivos dessa transição. Embora o planejamento seja uma atividade relevante para a aquisição da oralidade, descrever o que se pretende fazer, descontextualizado do brincar em si, em muitos casos representa a perda do lúdico, uma de suas principais características. O processo de rever o brincar também é questionado pela autora, que enfatiza que o lúdico prescinde de revisão. Para ela o brincar se esgota no próprio processo e não há produto a ser avaliado. Seria mais coerente deixar a criança escolher a área e brincar no tempo de atividade livre sem exigir dela explicações.

\subsection{A brincadeira no Modelo Pedagógico de Reggio Emília}

Na abordagem de Reggio Emilia, embora o eixo para a educação infantil não seja unicamente a brincadeira e muito mais a questão da exploração das diferentes linguagens expressivas da criança, Gandini (1999) conceitua o brincar como uma dessas linguagens e, nessa perspectiva, tendo grande valor educativo e de desenvolvimento cognitivo, motor, afetivo e relacional. 
O brincar aqui perpassa toda a proposta curricular, não ficando circunscrito a uma área espacial específica ou a um dado momento da rotina.

A área externa é pensada em termos de criação de espaços e possibilidades de brincar de diferentes formas e com diversos materiais. As áreas internas também contemplam essa questão: partindo das propostas de trabalho das próprias crianças ou do olhar atento para as possibilidades de intervenção e ampliação do interesse apresentado em certo tema, o educador organiza essas áreas de modo a oportunizar experiências novas e desafiadoras, entre elas as brincadeiras, apoiando e estimulando a criança a expressar-se de diferentes maneiras (Gandini, 1999).

Não existe nesse modelo pedagógico uma "hora de brincar", como é prática corrente em muitas unidades de educação infantil no universo do atendimento público paulista (paulistano, mais especialmente), mas sim um brincar fluido e contínuo, que permeia o fazer da criança.

A brincadeira surge como meio de experimentação, promotora de prazer, de interação entre os pares e com o adulto, conhecimento de capacidades individuais e fonte de descobertas. O protagonismo da criança, um dos eixos principais dessa proposta, contempla todas as atividades, entre elas o brincar.

\subsection{A Brincadeira na educação pública de São Paulo}

No Município de São Paulo, vários documentos emanados dos órgãos oficiais de controle e orientação enfatizam a importância do brincar para a educação da criança pequena. Dentre os mais recentes, está a proposta pedagógica da administração vigente no momento de redação deste trabalho, designada: Tempos e Espaços para a Infância e suas linguagens nos CEls, creches e EMEls na cidade de São Paulo (SME SP/2006) que defende o "Brincar, como principal linguagem da infância, [que] compreende práticas que envolvem jogos, brinquedos e brincadeiras que garantem o direito às crianças de se comunicarem e interagirem". (Ibidem p. 46).

Ao considerar os objetivos da educação infantil,

"Espera-se que a brincadeira infantil ocupe lugar privilegiado nas rotinas dos CEIs, das creches e das EMEls. Isso requer superar a concepção de muitos educadores de que o tempo de brincar nas instituições de educação infantil é uma exceção à norma de trabalho, ou uma atividade para preencher o tempo de espera" (Ibidem, p.48). 
Embora no documento citado a brincadeira esteja apresentada como eixo principal da proposta pedagógica para a criança de 0 a 6 anos, observações assistemáticas da prática desenvolvida apontam que essa priorização ainda não é realidade para a maioria das unidades educacionais municipais, ficando restrita apenas ao discurso dos educadores.

Wajskop (1995) já se referiu a esse quadro na escola pública, em pesquisa realizada em 1987. Analisando uma sala de pré-escola, constatou que havia uma concepção inatista e biológica da brincadeira, contrapondo-a ao trabalho. O brincar era visto como forma de equilibração orgânica, ou seja, para suprir necessidades biológicas de movimento e descontração. Nas poucas atividades denominadas pela educadora como "brincadeiras" havia total controle do adulto sobre as ações que deveriam ser realizadas pela criança (material, seqüência, parceiros) aparecendo essa dinâmica geralmente como forma apenas de seduzir essas crianças e prender sua atenção para o treinamento de alguns conteúdos "escolares" específicos que a educadora tinha como objetivo desenvolver.

Em outra pesquisa realizada entre 1997 e 1998, que atingiu 10\% do total de EMEls do município de São Paulo, Kishimoto (1999) encontrou aspectos que corroboram o pouco valor atribuído à brincadeira no espaço escolar. Entre eles, a distribuição do espaço da sala, que ficava completamente tomado por mesas e cadeiras; predominância das filas em diferentes momentos e atividades do dia; falta de acesso as crianças aos materiais e brinquedos; grande número de atividades dirigidas e cronometradas pela educadora; exigência da permanência da criança sentada e em silêncio; longo tempo de espera entre as atividades e, por fim, uma rotina que não previa momentos de brincadeira além do horário destinado ao parque.

O brincar apresentava-se como atividade recreativa, desprovida de potencialidade de aprendizagens significativas e, portanto, relegada a um papel secundário no desenvolvimento da criança. A brincadeira surgia na EMEI como forma de liberar energia excessiva da criança, como algo para se fazer quando sobrasse tempo ou ainda restrita a curtíssimos períodos de tempo entre as atividades consideradas realmente importantes e educativas (Kishimoto, 1999).

É interessante notar como as conclusões da pesquisa de Kishimoto coincidem, em grande medida, com aspectos levantados pelos educadores da EMEI em que a presente pesquisa realizou-se, sendo um dos elementos acionadores do 
movimento de mudança pretendido na proposta de Reorganização dos Espaços e das Atividades.

No momento atual, as disposições dos textos oficiais sobre a brincadeira traduzem-se em práticas nem sempre condizentes com os objetivos apontados nesses documentos.

Observações resultantes de vivências da pesquisadora junto à rede de educação infantil municipal, permitem inferir que nos CEls existe, atualmente, uma maior valorização do brincar e certa "tolerância" da atividade espontânea da criança até três anos, tanto pela família quanto pelos educadores. A partir dos quatro anos, portanto na idade comum de ingresso na EMEI, a oposição brincadeira/trabalho fica mais patente na unidade educacional. Consideram-se "trabalho" da criança as atividades de cunho escolarizante ${ }^{15}$ por elas realizadas e que têm como objetivo a alfabetização ou a escolaridade futura. As tarefas que se distanciam disso e se aproximam da brincadeira são vistas como meras coadjuvantes do processo educativo, portanto de menor valia.

Tais observações não devem desmerecer os esforços presentes em várias unidades de educação infantil em transformar esse estado de coisas. Contudo, o acompanhamento que se realiza em mais de 60 unidades de Educação Infantil do Município revela a regularidade de práticas pedagógicas na perspectiva escolarizante sobrepondo-se a outras propostas de educação infantil. Nota-se que, embora o discurso de valorização da brincadeira infantil esteja presente praticamente na totalidade das unidades de educação infantil, em grande parte delas as ações efetivas não são compatíveis com as idéias e palavras. A pesquisa de Kishimoto (1999) aponta justamente a incompatibilidade existente entre o discurso e a prática das unidades pesquisadas pela autora.

Esse distanciamento persistente entre discurso e prática relacionada à brincadeira na EMEI deve ser atribuído não à falta de conhecimento dos educadores de outras possibilidades de ação, mas à força exercida pela cristalizadas concepções de criança como ser inacabado e imperfeito. Por conseguinte, de uma educação infantil centrada na preparação, cujos educadores estejam aptos para

\footnotetext{
${ }^{15} \mathrm{O}$ termo escolarizante é aqui utilizado mantendo-se a perspectiva de Kishimoto (2002, p. 156), que simboliza a ênfase nas atividades de leitura, escrita e cálculo na educação infantil, não atendendo às necessidades e ao desenvolvimento infantil.
} 
transmitir os conhecimentos e os conteúdos mínimos necessários ao sucesso da criança na alfabetização e na escolaridade posterior.

As duas últimas administrações municipais (2001 a 2004 e 2005 até o momento), mesmo que de maneira bem diversa têm demonstrado preocupação com esse aspecto. Com isso, desenvolvem políticas públicas de formação de educadores, valorizando os direitos da criança, entre eles o brincar, considerando-a sujeito, produtora das culturas infantis.

\subsection{A brincadeira na proposta de Reorganização dos Espaços e das Atividades}

\section{A proposta pedagógica de Reorganização dos Espaços e das Atividades} revela-se, no interior do quadro da educação municipal, como uma iniciativa de trabalho diferenciada, que traz como um dos eixos principais a brincadeira.

No momento inicial da implantação dessa proposta ${ }^{16}$, embora a criança tivesse tempo e acesso aos materiais para brincar, a brincadeira foi valorizada apenas como forma de liberá-la da supervisão direta da educadora e assim possibilitar a esta o acompanhamento das atividades "importantes" e "realmente pedagógicas“, que eram desenvolvidas em pequenos grupos com sua supervisão direta junto a outras crianças. O brincar aparecia como entretenimento, coadjuvante do processo educativo, com uso de caráter instrumental e objetivos alheios à atividade. Notou-se que não havia, neste momento inicial do trabalho, preocupação com uma pedagogia que valorizasse a infância ou que objetivasse, em grande medida, o protagonismo da criança.

Com o avanço da implantação e o fortalecimento das discussões em torno da continuidade dos trabalhos, a brincadeira ganhou visibilidade e, em conversas informais ${ }^{17}$, notou-se que durante o momento do brincar, além do prazer evidente que a atividade proporcionava e da liberação do adulto, ocorriam diferentes tipos de interações e registravam-se aprendizagens muito significativas. Ademais, situações de brincadeiras criavam inúmeras possibilidades de intervenção da educadora com vistas à ampliação e aprofundamento de saberes que eram ali construídos e

\footnotetext{
${ }_{17}^{16}$ Designado no Capítulo 1 como Fase I da proposta.

17 É importante ressaltar que condições adversas de trabalho não possibilitavam momentos sistemáticos de encontro para troca de observações e análise dos trabalhos desenvolvidos. As trocas de experiências ocorriam de maneira informal e assistemática, em poucos momentos de encontro das educadoras por ocasião da mudança dos turnos de trabalho.
} 
mostravam-se, na maioria das vezes, muito mais interessantes para a criança do que as atividades inicialmente planejadas e dirigidas pela educadora

Esses novos aspectos, quando detectados, desestruturaram a hipótese inicial de que brincadeira seria coadjuvante, levando as educadoras a uma reflexão mais profunda sobre o brincar e suas possibilidades. Houve uma mudança expressiva das intenções educativas, o que levou a equipe a realizar uma série de estudos sobre o brincar, o protagonismo da criança e sobre algumas propostas pedagógicas de inspiração construtivista que valorizam a atividade da criança na educação da infância, particularmente os modelos pedagógicos de Reggio Emília e High Scope.

$\mathrm{Na}$ fase II, quando da realização deste estudo empírico, já se notou outro movimento, com a preocupação voltada ao brincar espontâneo da criança e uma valorização dessa atividade, sendo oferecidas oportunidades em termos de espaço, tempo e materiais de apoio à brincadeira, certo cuidado com o ambiente físico e alguma reflexão sobre os materiais que eram fornecidos.

Apesar disso, tal valorização estava mais vinculada à oportunidade de a criança exercer sua autonomia e respeitar seus desejos e necessidades do que propriamente ao brincar entendido como gerador de aprendizagens cultural e socialmente mais profundas, contextualizadas e significativas.

Isso pôde ser notado quando, nessa fase, observou-se a realização dos trabalhos orientados pelos adultos no momento das atividades no espaço reorganizado. Ao mesmo tempo em que era possibilitado a um grupo de crianças o exercício da brincadeira livre, tendo apoio de recursos para seu protagonismo, outros grupos de crianças com atividades dirigidas pelo adulto geralmente tinham tarefas descontextualizadas, vinculadas à aquisição de habilidades motoras, como recorte dirigido, desenho com tema determinado pelo educador, escrita de numerais etc., que não levavam em conta o protagonismo da criança.

Isto também ocorria no início do ano de 2006 com as propostas desenvolvidas pela educadora Luciana. Exemplos destas atividades poderão ser encontrados na Parte II deste trabalho, relacionada à análise da prática pedagógica e ao processo de tutoria desenvolvido.

Apesar dessas propostas bem dirigidas observou-se que em geral os educadores respeitavam nesses momentos o ritmo da criança para a realização da atividade e permitiam-Ihe certa autonomia para estabelecer interações com seus pares. 
$\mathrm{Na}$ unidade que desenvolveu e utiliza essa proposta pedagógica notamos que, de acordo com cada educadora, o brincar assume determinadas características, mas para a maioria a brincadeira ainda é utilizada como estratégia para entretenimento da criança enquanto a mesma é liberada para atuar no trabalho "pedagógico" com grupos sob sua orientação, geralmente subdivisões das $35 / 37$ crianças em grupos de oito.

Pode-se dizer que existe muito mais brincadeira dentro da escola acompanhada na pesquisa. $O$ brincar tem espaço na rotina em termos de tempo, tem uma organização espacial que o privilegia e aporte de material que lhe dá sustentação; os objetivos, porém, desse brincar ainda não são consensuais entre a equipe escolar.

Por ocasião da coleta de dados deste estudo empírico era proposta da unidade escolar realizar discussões sobre a brincadeira. Essas discussões seriam implementadas no segundo semestre de 2006, visando a uma reflexão mais profunda e a definição de alguns consensos necessários a uma prática pedagógica considerada pertinente à proposta de Reorganização dos Espaços e das Atividades.

Essas reuniões não ocorreram sistematicamente durante 0 ano em que a pesquisa se desenvolveu, sendo o brincar tematizado entre os professores em alguns momentos do trabalho coletivo, como troca de experiências ou observações da prática pedagógica, sem uma sistematização ou como um foco prioritário de intervenção da coordenadora pedagógica. 
CAPÍTULO 3

APONTAMENTOS SOBRE QUALIDADE NA EDUCAÇÃO INFANTIL: UM OLHAR POSSÍVEL 
Neste trabalho cabe tecer algumas considerações sobre a questão da qualidade na educação infantil, uma vez que o processo de pesquisa-ação desenvolvido teve como base a possibilidade de identificação e construção de um processo contínuo de melhoria da qualidade da educação infantil. Esse propósito foi também assumido por uma educadora (professora Luciana) no interior da EMEI Eurípedes Simões de Paula, que se propôs a uma parceria de formaçãoinvestigação.

Pensar em qualidade está, neste caso, vinculado ao papel educativo atribuído às instituições de educação infantil e aos objetivos que se pretende atingir junto às crianças pequenas.

Oliveira-Formosinho (2002a) destaca que os efeitos do processo educativo desenvolvido nas unidades de educação infantil, a curto, médio e longo prazo, dependem diretamente da qualidade da educação que se promove.

No entanto, o conceito de qualidade é polissêmico, pois varia de acordo com os atores sociais, sendo valorativo, pessoal e contextual. No contexto institucional de uma unidade educacional atrelada ao governo municipal, como é o caso do locus dessa investigação, os envolvidos (sejam pais, educadores ou representantes do poder público) podem ter diferentes concepções sobre o que seria qualidade do atendimento à infância.

Dentro de suas histórias de vida os indivíduos experienciam e constroem formas singulares de interpretar os contextos de que fazem parte. Essas interpretações da experiência se expressam em concepções acerca do que é considerado bom, belo e ideal. Os valores construídos são derivados das experiências do indivíduo no universo da cultura e são expressos pelas suas ações.

Segundo Moss, "a importância crescente da qualidade no campo das instituições dedicadas à primeira infância pode ser entendida em relação à busca modernista pela ordem e à certeza fundamentadas na objetividade e na quantificação". (Moss, 2003, p. 121). O autor afirma que o discurso da qualidade oferece confiança e tranqüilidade e que, por vezes, o simples uso do termo qualidade passa a significar que algo merece confiança e é realmente bom. No entanto, é enfático ao admitir que "fundamental para a construção da qualidade é a suposição da existência de que há uma entidade ou essência de qualidade, que é uma verdade conhecível, objetiva e certa que está 'lá fora' esperando para ser descoberta" (ibidem, p. 127). 
O autor alerta para o fato de que a especificação de critérios de qualidade é um processo de construção permeado por influências sociais, culturais e políticas, realizado por um grupo constituído de "autoridade" para tal, autoridade essa que pode vir de várias fontes, como: o status, a posição política ou burocrática, o reconhecimento da experiência no campo etc. Esse processo, segundo Moss, não é dialógico, à medida que não envolve os interlocutores como um todo e termina que $a$ "qualidade é apresentada como uma verdade universal isenta de valor e cultura, além de aplicável, de igual maneira, em qualquer lugar no campo em consideração: em suma, qualidade é um conceito descontextualizado." (ibidem, p. 128).

O discurso da qualidade da educação infantil gerou a construção de uma série de normas e diretrizes que indicam o que seria uma prática ideal para provisão de cuidados e educação da primeira infância. Apesar desses indicadores não serem critérios avaliativos, proporcionam definições de qualidade aceitas pela sociedade dentro de um determinado contexto histórico e cultural.

Na mesma direção, Campos (1998, p. 41) afirma que "é preciso reconhecer que existem muitas maneiras de se conceber a qualidade na educação e não uma única perspectiva universalmente válida".

No Brasil, uma série de estudos sobre o atendimento à infância teve como resultado a criação de parâmetros norteadores das ações a serem desenvolvidas junto às crianças pequenas de diferentes regiões, considerando-se, é claro, a pluralidade de ações possíveis. Entre esses encontram-se os Parâmetros Nacionais de Qualidade para a Educação Infantil, publicado pelo Ministério da Educação em $2006^{18}$.

Campos e Cruz (2006, p. 15) sintetizam alguns desses estudos sobre qualidade, afirmando que:

De forma geral, para resumir o debate sobre qualidade da educação é importante retomar suas principais conclusões.

- a qualidade é um conceito socialmente construído, sujeito a constantes negociações;

- depende do contexto;

- baseia-se em direitos, necessidades, demandas, conhecimento e possibilidades;

- a definição de critérios de qualidade está constantemente tensionada por essas diferentes perspectivas.

\footnotetext{
${ }^{18}$ Os Parâmetros Nacionais de Qualidade para a Educação Infantil encontram-se acessíveis no site do Ministério da Educação: http://portal.mec.gov.br/seb/arquivos/pdf/Educinf/.
} 
Moss (2003) enfatiza que a questão da qualidade não se torna um problema desde que reconheçamos que não é um conceito neutro, mas um conceito que optamos por refutar ou aceitar.

Para Campos (1998, p. 42) "no Brasil não há tradição de uso de sistemas de avaliação de qualidade no campo da educação infantil". Quanto à elaboração de padrões mínimos de qualidade, esclarece que a definição desses padrões "visa definir um limite abaixo do qual os serviços são considerados como apresentando riscos inaceitáveis para as crianças" (ibidem).

Para a autora o estabelecimento de padrões mínimos deve ser feito pela adaptação de indicadores de qualidade que sejam simples e claros, formulados de maneira compreensível para a maioria das pessoas, que possam ser facilmente aferidos e devem levar em conta as características da realidade sobre a qual se quer atuar. Enfatiza ainda que as questões ligadas à qualidade, mais complexas e difíceis de verificar, devem ser deixadas para os programas de melhoria processual da qualidade (ibidem).

Pensando em qualidade na educação infantil enquanto conceito histórica e socialmente contextualizado e, portanto, processo em constante construção, sujeito a múltiplas interpretações, vale explicitar como esse conceito foi concebido no estudo ora apresentado.

A discussão sobre a qualidade proposta neste estudo empírico refere-se a algo que, apesar de se pautar em indicadores ou parâmetros elencados por nossa sociedade como adequados, extrapola-os, principalmente pela concepção de qualidade não como critério mensurável, mas como construção “... aprofundamento do 'entendimento' da instituição dedicada à primeira infância e a seus projetos, em particular ao trabalho pedagógico, para construir significado a partir do que está acontecendo" (Moss, 2003, p. 143).

A perspectiva de qualidade eleita na pesquisa é ecológica, no sentido dado a esse termo por Bronfenbrenner (2002, p. 18), para quem

... a ecologia do desenvolvimento humano envolve o estudo científico da acomodação progressiva, mútua entre um ser humano ativo, em desenvolvimento, e as propriedades mutantes dos ambientes imediatos em que a pessoa em desenvolvimento vive, conforme esse processo é afetado pelas relações entre esses ambientes, e pelos contextos mais amplos em que os ambientes estão inseridos. 
A qualidade compreendida na perspectiva ecológica, conforme conceito de Bronfenbrenner (2002) e tal qual defendida no campo da educação da infância por Oliveira-Formosinho (2002a), assume significado nesta pesquisa quando se pensa no agrupamento de educação infantil como microssistema que envolve vários atores sociais (no caso, o grupo de crianças e o educador). E também por estar este contexto menor atrelado a outros contextos de âmbito progressivamente mais ampliado, como os outros agrupamentos, os demais educadores da unidade, a família e a comunidade, o sistema de educação municipal, entre outros. Esses membros são todos pertencentes a um todo social e cultural historicamente configurado, estando o microssistema em apreço necessariamente afetado por influências de outros sistemas, ao mesmo tempo em que também atua enquanto agente de modificação da realidade dessas outras esferas.

A concepção de qualidade anunciada também é construtivista, pois não vem elaborada e finalizada para análise externa, com parâmetros completamente definidos e estáticos, com uma escala de valores quantitativa ou algo nesse sentido. A qualidade é entendida aqui como um processo de construção, um fazer e refazer constante no dia-a-dia da prática pedagógica, tendo como protagonistas todos os envolvidos direta e indiretamente nesse processo (Oliveira-Formosinho, 2002a).

Qualidade define-se como um processo de melhoria progressiva e validação das experiências protagonizadas pela educadora que, articuladas a outros saberes e reflexões, e construídas no contexto do trabalho pedagógico e da pesquisa, levemna à realização de práticas cada vez mais afinadas, que objetivam o bem estar, a aprendizagem e o desenvolvimento das crianças.

A educadora Luciana, parceira no processo de investigação dentro do contexto do estudo, é compreendida como a principal arquiteta do processo de construção dessa qualidade almejada. Ela protagoniza as mudanças na prática pedagógica, mas tem a pesquisadora como parceira nesse percurso, que toma então a perspectiva de co-autoria no processo de transformação da realidade.

Durante o processo de pesquisa-ação o conceito de qualidade e as condições julgadas necessárias à promoção da melhoria da qualidade do trabalho foram alvos de reflexões conjuntas (educadora e pesquisadora), com o intuito de afinar olhares e construir significados compartilhados.

O acompanhamento da ação da educadora foi pautado na reflexão de sua prática cotidiana junto ao agrupamento de crianças e teve entre seus objetivos a 
identificação dos pontos nevrálgicos da prática pedagógica, o reconhecimento dos aspectos que exigiam maior atenção ou intervenções sistemáticas e, ainda, a tomada de decisões, visando a melhoria progressiva da qualidade do atendimento prestado à criança pequena.

Portanto, o processo de formação profissional foi considerado, neste estudo, como uma condição promotora de transformações de práticas e melhoria de qualidade do trabalho com o público infantil.

\subsection{Formação Profissional como promotora de Qualidade}

$\mathrm{Na}$ perspectiva adotada neste estudo concebe-se a possibilidade de a formação ocorrer em diferentes contextos de vida da educadora. No entanto, o foco das atenções recaiu sobre o processo de parceria que se instalou entre a educadora Luciana e a pesquisadora, na tentativa de apreender os impactos dessa ação de parceria e tutoria entre pares na transformação das práticas educativas.

Compreende-se que várias perspectivas teóricas podem ser adotadas para planejar, acompanhar e avaliar o processo de formação dos educadores de infância. O objetivo deste item é traçar, em linhas gerais, as bases conceituais eleitas neste estudo no que se refere ao processo formativo em apreço.

Justamente pelo reconhecimento da importância e complexidade dessa temática, há clareza da impossibilidade de aprofundamento das discussões neste trabalho. Fez-se a opção por tecer um breve panorama conceitual, avaliando que esse procedimento seria útil à compreensão dos principais pressupostos que nortearam o processo formativo implementado.

Em consonância com o modelo de qualidade adotado, optou-se pelo viés teórico relacionado com a ecologia do desenvolvimento humano (Bronfenbrenner, 2002).

Nessa direção, Oliveira-Formosinho (2001, pp. 137-138) vai destacar que:

O modelo ecológico de supervisão situa-se na perspectiva de supervisão como apoio à formação e inovação, visando a melhoria do desempenho do docente [...] No modelo ecológico a supervisão docente é aplicável a todo percurso da formação, pois como modelo teórico não varia fundamentalmente quando pensado para formação inicial ou contínua. 
Considerou-se o processo de formação continuada como uma das esferas da supervisão. Para Oliveira Formosinho (2001, p. 141), supervisão é

... um processo de apoio à aprendizagem profissional do educador [...] o qual está a serviço do processo de aprendizagem dos alunos [...], no contexto de uma sociedade que tem uma tradição cultural que envolve saberes, normas, crenças e valores.

No âmbito do modelo ecológico a supervisão tem as seguintes características: a) processo de apoio à formação; b) formação é conceituada como aprendizagem profissional contínua que envolve a pessoa, seus saberes, suas funções e realizações; c) caráter sistemático, englobando ação e reflexão sobre as práticas; d) processo reflexivo que envolve ações de observar, analisar, dialogar, projetar, agir, refletir, planejar, agir de novo, comunicar, avaliar etc. e) processo de mudança compreendido como tendo continuidade em outros processos; f) caráter de abertura, de compartilhamento da vivência com contextos mais amplos de crenças e valores (Oliveira-Formosinho, 2001).

Observando o panorama da educação infantil brasileira, Campos(2006) enfatiza que os resultados de vários estudos apontam que as educadoras de préescola dificilmente conseguem escapar do modelo excessivamente escolarizante, baseado em práticas tradicionalmente utilizadas no ensino primário.

Com a intenção de ampliar o olhar da educadora, possibilitando-Ihe a eleição de objetivos e ações que transcendessem as práticas escolarizantes e gerassem novas possibilidades de ação, a formação em serviço veio mostrar-se como opção para o processo formativo desenvolvido neste estudo.

Conforme Moura, "devemos considerar, no processo formativo, o sujeitoprofessor que, como pessoa, agrega novos saberes nas soluções construídas, para a organização de novas ações e para a realização de sua atividade profissional" (Moura, 2004, p. 266).

Pinazza (2004, p. 375) destaca que:

Historicamente as iniciativas de formação em serviço tiveram como traços característicos: ocorrência episódica (estanque e descontínua) e distância entre teorias abordadas e práticas vivenciadas pelos profissionais de educação infantil. 
Malglaive (1995) aponta como principal dificuldade dos processos pedagógicos que procuram apoiar-se na prática a existência de uma ruptura entre a ação, tal como ela se desenvolve concretamente, e o desenvolvimento de mecanismos cognitivos que permitam compreender as razões que a motivaram.

Para mudar a ação é necessário ter uma idéia mais clara do que se é, do que se tem de significados construídos e do que se faz no campo da educação. Sacristán (2007, p. 160) pondera que "é preciso revelar o panorama confuso em que vivemos e superar a perda do horizonte que sofremos na luta diária da gestão da docência".

Acredita-se que quanto mais for obscuro esse panorama de fundo maior será a dificuldade de realizar avanços nas práticas e nas concepções. A falta de consciência dos valores e crenças que dão suporte às práticas leva o educador a um eterno reproduzir de ações já formatadas e nem sempre adequadas.

Para Pinazza (2004, p. 381) "a formação deve necessariamente pautar-se no exercício crítico-reflexivo que conduza à autonomia e à auto-formação participada".

Perrenoud (2002) vai falar que não somos conscientes de todos nossos atos, bem como não temos clareza de que todos eles surgem de estruturas estáveis e que muitas vezes essa falta de consciência clara é funcional, como se o nosso organismo fizesse algo como no "piloto automático" por ser mais econômico psiquicamente.

Quanto ao processo de transformação das ações, Kishimoto (2004) esclarece que os saberes baseados em experiências de vida de cada indivíduo arraigam-se em suas práticas. Aponta a autora que, destes saberes, alguns têm relevância para a educação da criança, outros reproduzem práticas inadequadas. Afirma também que a mudança não é tarefa fácil, nem rápida.

Somente a reflexão sobre a prática circunscrita por outros olhares, outras concepções tem poder de mudança [...] a cultura docente demorou muito tempo para construir sua solidez. A demolição requererá tempo e persistência, e não é a teoria que fará demolir tal estrutura, e sim o diálogo constante com a prática iluminada por novas convicções [...] Hoje a discussão sobre a qualidade incide na construção de uma prática coletiva, baseada em aprendizagens partilhadas no lócus da escola, com parceiros de várias naturezas" (Kishimoto, 2004, p. 337). 
Pensar a formação continuada enquanto processo capaz de mobilizar a desconstrução e reconstrução das práticas, dos saberes e das concepções, leva, indubitavelmente, à necessidade de entender como o educador atribui significados ao vivido e quais os meios possíveis para tornar esses significados acessíveis.

Buscando esclarecer sobre o processo de construção de significados, Garmston, Lipton e Kaiser (2002, p. 82) afirmam que "os indivíduos percebem e armazenam os dados de acordo com as predisposições pessoais para assimilação de informação, de acordo com as diferentes modalidades e de acordo com seus estilos cognitivos".

Para os autores, o processo de armazenamento e interpretação das vivências do indivíduo tem início anterior ao discurso. Sendo assim, para acessar esses conteúdos se faz necessária uma ação de mediação baseada em interações verbais (ibidem).

Garmston e Wellman (1995, in Garmston, Lipton e Kaiser, 2002), indicam três princípios básicos para compreensão e aplicação dessa metodologia no trabalho de supervisão dos educadores:

- a soma de construção de significados de um educador reside internamente no nível consciente e inconsciente e serve como critério para percepções, decisões e para seu comportamento;

- a linguagem torna estes significados acessíveis a ambas as partes numa transação verbal;

- através da linguagem os significados construídos podem ser revistos, refinados, enriquecidos e modificados.

Os significados construídos fazem parte de diferentes construtos mentais, que podem ou não estar localizados no âmbito da consciência.

Segundo Garmston, Lipton e Kaiser (2002), os três princípios acima colocados correspondem a três desses construtos: a estrutura profunda, estrutura de referência e estrutura de superfície. A estrutura profunda não está acessível pela consciência. A estrutura de referência só se torna acessível através da mediação realizada pela linguagem, quando vão ocorrendo intercâmbios com os significados já construídos e que são passíveis de intervenção através da estrutura de superfície: 
superfície poderão também servir para mediar as estruturas profundas e as estruturas de referência, para recuperar experiências e alargar o leque de escolhas de modo a auxiliar as pessoas na modificação de suas próprias estruturas profundas (Garmston, Lipton e Kaiser, 2002, p. 87).

Além da tentativa de compreensão sobre o mecanismo de construção de significados realizado pela educadora e o esforço para dar visibilidade aos valores e crenças que norteavam sua ação, buscou-se neste processo formativo, a partir da tematização das práticas desenvolvidas junto às crianças, uma interlocução da teoria com a prática.

Esse processo deu-se na direção dos pressupostos estabelecidos por Malglaive (1995, pp. 70-71):

Os saberes teóricos não mantêm relações operatórias diretas com as práticas. O único efeito prático de um saber teórico é dar a conhecer, e não permitir fazer: dizer o que é e não o que deve ser [...]

A relação que o saber teórico estabelece com a prática não é uma relação de aplicação, como se diz freqüentemente, mas uma relação de intervenção. Uma teoria não se aplica na prática: ela investe-se ai, tornando-se o objeto (de conhecimento) que permite agir mais eficazmente sobre o real, atuando sobre a representação pensada.

Para Malglaive (1995, p. 80) todo processo, seja diretamente mediado ou não por outros indivíduos, pode manifestar-se num conjunto de práticas diferentes das anteriores, cujo desenvolvimento é direcionado à eficácia do ato humano. Esses atos, porém, segundo a autora, "só ganham a sua real natureza no saber-fazer por meio da coerência interna, ligada a uma transformação significativa de um objeto ou de determinada atitude do agente que a suporta".

A autora vai afirmar que não existem, portanto, saberes-fazeres definitivamente identificáveis e delimitáveis, visto estarem ligados à coerência interna dos indivíduos (ibidem).

O processo reflexivo que visa a construção de novos significados (voltados à análise da prática educativa) passa, necessariamente, pela desconstrução feita, pelo próprio indivíduo, de significados anteriormente atribuídos, conscientes ou não. Portanto, o papel principal neste processo é do próprio educador, contudo considera-se que o parceiro que irá assumir o papel de mediador junto a esse educador deve fazê-lo para "intervir entre um aprendiz e seu ambiente, salientando 
dados potencialmente relevantes, a partir dos quais o aprendiz constrói novos significados" (Oliveira-Formosinho, 2002c, p. 88).

Segundo Perrenoud (2002, p. 13),

Todos nós refletimos na ação e sobre a ação e nem por isso nos tornamos profissionais reflexivos. É preciso estabelecer a distinção entre a postura reflexiva do profissional e a reflexão episódica de todos nós sobre o que fazemos.

Sobre o processo reflexivo, Perrenoud (2002), referindo-se aos estudos de Schön, vai distinguir dois caminhos para a reflexão. A reflexão durante a ação implica perguntar-se sobre o que está acontecendo, o que se vai fazer, os desvios que precisamos tomar e pode ser um processo que necessite de resposta imediata a partir da situação vivenciada ou da sucessão de várias ações que fazem parte de uma situação de longo alcance. Já refletir sobre a ação é tomar a própria ação como objeto de reflexão, compará-la com modelos de "ideal" e explicar ou criticar essa prática.

Para o autor "a reflexão não se limita a uma evocação, mas passa por uma crítica, por uma análise, por uma relação com regras, teorias ou outras ações, imaginadas ou realizadas em uma situação análoga” (ibidem, 2002, p. 31).

O desenvolvimento de uma prática reflexiva é aprender a obter diversos benefícios da reflexão:

- um ajuste dos esquemas de ação que permita uma intervenção mais rápida, mais direcionada ou mais segura;

- um reforço da imagem de si como profissional reflexivo em processo de evolução

- um saber capitalizado que permite compreender e dominar ouros problemas profissionais (Perrenoud, 2002, p. 51).

No estudo empírico realizado considerou-se que o objetivo do processo formativo era a mudança da perspectiva escolarizante, centrada no adulto, para uma ação centrada na criança. Fez-se necessário que a educadora tomasse consciência das ações que realizava, das motivações que a levavam à ação e dos impactos dessas ações nas crianças.

A perspectiva atribuída ao processo formativo buscou a superação da dicotomia em que o processo reflexivo se contrapõe à prática educativa. 
A tradição verbalista dos cursos de formação de professores coloca o aluno em formação em contato com os livros, no interior da universidade ou cursos de formação, mas pouco se vai à realidade, às escolas para observar e aprender no contexto em que se processa a relação ensino/aprendizagem (Kishimoto, 2007, p. 109).

A perspectiva de formação adotada neste estudo foi a de realização de um processo de intervenção co-operada (operada conjuntamente), o que implicou a colaboração (laboração em conjunto), desenvolvida em parceria (colaboração pesquisadora/educadora), no sentido atribuído aos termos por Oliveira-Formosinho (2002d).

Esse tipo de intervenção exige que haja um genuíno propósito de aceitar uma caminhada em comum. A cooperação exige a partilha de reflexões e práticas (ibidem).

Perrenoud vai dizer que

Quando visa à transformação das pessoas, de suas atitudes, de suas representações e de seus atos, a análise das práticas exige que todos realizem um trabalho concreto sobre si mesmos; ela exige tempo e esforços, expõe ao olhar alheio, estimula o questionamento (Perrenoud, 2002, p. 121).

Mas só pode causar efeitos reais de transformação se o profissional se envolver de fato com o processo. A qualidade do processo formativo e também dos feitos deste passam necessariamente pelo papel ativo da educadora na resignificação de seus fazeres cotidianos à luz da reflexão partilhada.

O processo formativo foi neste trabalho entendido como: a) um processo de re-significação; b) efetivado em parceria, mas cujo protagonismo era da educadora; c) orientado por crenças e valores nem sempre explícitos ou conscientes, mas que se tinha como objetivo conhecer; d) processo sujeito à desconstrução e reconstrução de significados, através de mediações adequadas; e) realizado através de processo reflexivo conjunto e co-construído (educadora e pesquisadora); f) intermediado por transações verbais; g) orientado para a transformação das ações imediatas e das concepções que Ihe davam significação. 
A perspectiva de formação adotada neste estudo foi ao encontro da proposta da tutoria entre pares ${ }^{19}$, eleita como opção metodológica norteadora do processo formativo da educadora Luciana, fundamentado nos pressupostos da pesquisaação.

Segundo Kishimoto (2002, p. 111) "atribuir à formação pedagógica estatuto científico, aliando a investigação e a formação, parece ser o caminho para a construção de um novo perfil profissional".

$\mathrm{Na}$ mesma direção, Perrenoud (2002) vai dizer que em contado com a pesquisa, o que os professores podem aprender vem mais da capacidade que esta apresenta de subverter a percepção, revelar o oculto, estabelecer relações que não saltam aos olhos, do que as questões relacionadas ao rigor metodológico.

Para o autor, o processo reflexivo tem efeitos para além da modificação da situação imediata, age como disparador de outros processos de re-significação das práticas (ibidem). Decorre daí que o caminho formativo defendido e efetivado neste trabalho relacionou-se com a transformação das práticas efetivadas, deslocando-se da perspectiva escolarizante, objetivando como conquista progressiva da qualidade a ação realizada junto à criança pequena (ibidem).

Em última instância, inovar é transformar a própria prática, o que não
pode acontecer sem uma análise do que efeito e das razões para
manter ou mudar. A fonte da inovação endógena é a prática reflexiva
que é mobilizadora de uma tomada de consciência e da elaboração
de projetos alternativos (Perrenoud, 2002, p. 62).

Avalia-se que essa compreensão da prática pedagógica, que ultrapassava a ação imediata e atribuía sentido à ação, a partir do processo reflexivo, foi capaz de gerar na educadora motivação e empenho necessários à implementação das mudanças em sua prática, possibilitando-Ihe a adoção do conceito de conquista da qualidade enquanto processo contínuo e progressivo ${ }^{20}$.

\footnotetext{
${ }^{19} \mathrm{O}$ capítulo 4.2, Procedimentos Metodológicos, tratará do processo de tutoria entre pares.

${ }^{20}$ No capítulo 5, EIXO I, há maiores detalhes das ações desenvolvidas pela educadora Luciana e pela pesquisadora no transcorrer do processo formativo.
} 


\subsection{Fluxo e Envolvimento como indicadores da qualidade do contexto educativo}

Além de olhar a prática pedagógica a partir do processo de formação da educadora Luciana, o outro eixo da investigação utilizou como dados de análise o envolvimento da criança em suas atividades. O propósito foi examinar o impacto das ações da educadora nas crianças, ao longo do trajeto de pesquisa-ação efetivado.

Com a oportunidade de parceria possibilitada pela pesquisa-ação, elegeu-se como um dos parâmetros de análise dos efeitos da prática pedagógica desenvolvida a Escala de Envolvimento da Criança - LIS-YC (Laevers, 1994) ${ }^{21}$, considerando-a, além de um instrumento auxiliar para formação reflexiva da educadora, um indicador da qualidade da educação infantil implementada.

Oliveira-Formosinho (2004, pp. 85,86) considera adequado o uso da Escala de Envolvimento no processo de avaliação formativa para análise dos processos de ensino-aprendizagem. A autora argumenta que "... para construir a qualidade num processo dialógico a partir do interior, temos que nos centrar nos processos, sem nos esquecer dos produtos..." e enfatiza que esse instrumento permite construir a qualidade através do processo e constitui, simultaneamente, uma perspectiva sobre o que seria qualidade e um instrumento para avaliá-la.

Laevers (2000), referindo-se à qualidade da educação infantil, afirma que se o desejo é saber se uma escola faz ou não um bom trabalho, o que realmente importa são os objetivos que essa escola tem e o efeito produzido nas crianças, mediante a efetiva consecução desses objetivos. Afirma o autor que se deve analisar os processos de desenvolvimento ocorridos durante a atividade de ensino, consideradas duas variáveis identificadas por ele: bem-estar e envolvimento. A conceituação proposta por Laevers $(1994,1996,2000)$ para o envolvimento da criança está relacionada aos estudos de Csikszentmihalyi $(1992,1999)$ sobre a teoria do fluxo.

Este trabalho tratará, sinteticamente, dos conceitos de fluxo e envolvimento, pois são essenciais à compreensão da base teórica que fundamenta a Escala de

\footnotetext{
${ }^{21}$ Mais adiante, na Parte II deste trabalho, há uma explicitação detalhada dessa Escala, de sua base conceitual e da maneira como foi utilizada no estudo empírico.
} 
Envolvimento da Criança, utilizada no estudo empírico para acompanhar o efeito da prática pedagógica nas crianças (Eixo 2).

Envolvimento é definido por Laevers como:

“... uma qualidade da atividade humana que é: a) reconhecido pela concentração e persistência; b) caracterizado pela motivação, atração e entrega à situação, abertura aos estímulos e intensidade da experiência (quer ao nível físico, quer ao nível cognitivo) e por uma profunda satisfação e energia; c) determinado pelo impulso exploratório e pelo padrão individual ao nível desenvolvimental; e) indicador de que o desenvolvimento está a ter lugar" (Laevers, 1994a, pp. 159-172, in Oliveira-Formosinho, 2004, p. 86).

Envolvimento é um indicador da atividade mental da criança, gerador de estados de concentração, perseverança, motivação intrínseca, atenção e experiências intensas de aprendizagens aliadas a uma satisfação profunda. Há fascinação. Esses estados mentais levam a criança a procurar satisfação e, portanto, elas gostam de estar envolvidas. O mesmo ocorre com os adultos.

Todavia, o envolvimento não é um tipo de atividade, é um atributo da experiência vivenciada, todas as atividades podem ou não apresentar a qualidade do envolvimento (Laevers, 2000).

Na mesma direção, Csikszentmihalyi (1999) chamou de experiência do fluxo os momentos em que os sentimentos, os pensamentos e os desejos se harmonizam. A ação do indivíduo está relacionada ao que ele deseja e à maneira como vive essa experiência. Para o autor o fluxo costuma ocorrer quando uma pessoa encara um conjunto claro de metas que exigem respostas apropriadas. A busca dessas metas focaliza a energia psíquica em curto prazo e, a longo prazo, são essas metas que vão moldando o self.

As atividades de fluxo costumam: 1) permitir que a pessoa se concentre em metas límpidas e compatíveis; 2) oferecer feedback imediato, deixando claro o desempenho; 3) ocorrer quando as habilidades de uma pessoa estão no limiar de sua capacidade de controle. Experiências ótimas geralmente envolvem um fino equilíbrio entre a capacidade de o indivíduo agir e as oportunidades disponíveis para a ação ocorrer (ibidem).

Relacionando os conceitos de envolvimento/fluxo com a aprendizagem, Csikszentmihalyi (1999, p. 33) afirma que a experiência do fluxo age como imã para o aprendizado, isto é, para o desenvolvimento de novos desafios e habilidades. Para 
ele, "as emoções, intenções e pensamentos não atravessam a consciência como elementos distintos da experiência, mas que estão constantemente interconectados e se modificam uns aos outros à medida que avançam". Afirma o autor:

As emoções se referem a estados interiores de consciência.
Emoções negativas como tristeza, medo, ansiedade ou tédio
produzem "entropia psíquica" na mente, isto é, um estado em que
não podemos usar a atenção de maneira eficaz para lidar com
tarefas externas, porque precisamos dela para restaurar uma ordem
interior subjetiva. Emoções positivas como felicidade, força ou alerta,
são estados de "negantropia psíquica" ou entropia negativa, porque
não precisamos de atenção para refletir e sentir pena de nós mesmos
e a energia psíquica pode fluir livremente para qualquer pensamento
ou tarefa em que escolhemos investir (ibidem, p. 30).

Em Vygotsky (2003b) há a afirmação de que a atenção da criança depende quase por completo de seu interesse e a distração dela na escola está associada à diferença entre seus próprios interesses e tarefas que lhe são dadas. Laevers (2000) afirma também que a criança demonstra, quando envolvida numa atividade, interesse e concentração muito superiores aos esperados para sua faixa etária. No fenômeno do envolvimento encontramos uma motivação intrínseca enorme. Para o autor, uma pessoa só está realmente envolvida quando funciona no limite de suas capacidades, quando mobiliza todas suas competências. Devido a isso não há envolvimento numa situação rotineira e sem desafios e também ele não existe se a tarefa é demasiadamente difícil.

Csikszentmihalyi (1999, p.38) ressalta que: "devido à exigência total de energia psíquica, uma pessoa no fluxo está completamente concentrada, não há espaço na consciência para pensamentos que distraiam, para pensamentos incoerentes". Afirma ainda que, "quando fluímos, estamos no comando de nossa energia psíquica e tudo que fazemos acrescenta ordem à consciência" (idem, 1992, p. 68).

Csikszentmihalyi (1992, 1999) e Laevers $(1994,2000)$ não propõem uma relação de causa e efeito direta entre envolvimento ou fluxo e aprendizagem. Contudo, enfatizam que é nesses momentos de entropia negativa, ou seja, de completa entrega à atividade que se está realizando que a aprendizagem tem maiores condições de ocorrer. 
Buscando estabelecer relações entre o envolvimento da criança na atividade e o contexto educativo de qualidade, é possível relembrar Pascal e Bertran (1996, p. 29) que, ao tratar do envolvimento, afirmam:

[...] este conceito está ligado diretamente ao impulso exploratório das crianças e abrange também o nível de concentração e motivação da criança... o envolvimento pode ser visto como estando ligado a noções de "correspondência" entre a capacidade e o desafio colocado por uma atividade. O envolvimento reflete também a finalidade, relevância e interesse que essa atividade tem para a criança.

O envolvimento é, portanto, um estado mutável atrelado à qualidade do contexto da ação. Observar o envolvimento da criança na atividade desenvolvida na unidade educacional pode dar indicadores seguros sobre a qualidade da educação que ali está sendo implementada.

Segundo Kishimoto (2002), é o gestor do currículo que organiza as condições ambientais para potencializar a aprendizagem e o desenvolvimento da criança.

Ao escolher o envolvimento da criança na atividade como uma forma de analisar a qualidade do atendimento efetivada, o presente estudo procurou eleger indicadores confiáveis, que pudessem, junto com outras fontes, acompanhar a prática desenvolvida na unidade educacional, trazendo elementos de análise partilháveis nos momentos de formação da educadora durante o processo de pesquisa-ação.

O objetivo da utilização dos escores da Escala de Envolvimento da Criança não foi classificar as crianças como envolvidas ou não envolvidas, nem tampouco classificar a prática pedagógica como de alta ou baixa qualidade. $\mathrm{O}$ instrumento foi utilizado para promover elementos de reflexão da educadora e da pesquisadora sobre as ações educativas desenvolvidas. Permitiu, também, dimensionar os avanços vividos e os desafios impostos no que diz respeito às mudanças processadas no ambiente, na disponibilização dos materiais e nas relações interpessoais, ou seja, rever a prática para replanejar a ação, objetivando o aprimoramento progressivo do fazer educativo. 
PARTE II - ESTUDO EMPÍRICO

CAPÍTULO 4 - METODOLOGIA DA INVESTIGAÇÃO 


\subsection{Contexto da investigação}

Neste capítulo será apresentada a unidade educacional e o agrupamento com os quais o estudo se desenvolveu.

O estudo empírico foi realizado na Escola Municipal de Educação Infantil (EMEI) Eurípedes Simões de Paula, durante o ano de 2006.

A unidade educacional localiza-se na Zona Oeste da cidade de São Paulo, Bairro de Pirituba. Trata-se de uma região periférica que tem recursos razoáveis de transporte (ônibus, lotação e trem), porém escassas possibilidades de atendimento à saúde e de lazer.

$\mathrm{Na}$ área correspondente à região de Pirituba e arredores, conforme dados do censo do Instituto Brasileiro de Geografia e Estatística (IBGE), realizado em 2000, há cerca de 120 favelas onde moram 549.000 pessoas, estando duas destas favelas muito próximas da unidade educacional em questão.

A região onde a unidade educacional está instalada conta com várias residências de classe média baixa e também com grande número de casas que não têm regularização, com serviços de fornecimento de água, esgoto e iluminação são clandestinos.A área é classificada conforme dados oficiais do mapa de inclusão/exclusão social do município como tendo índice de Desenvolvimento Humano (IDH) de 0,49, que a coloca entre as áreas em que há grande concentração populacional, elevado número de crianças de idade inferior a 6 anos e lares que se caracterizam pela baixa renda do chefe da família.

A unidade educacional em que o estudo desenvolveu-se, é uma instituição de educação infantil pertencente ao quadro da educação pública municipal da Cidade de São Paulo ( EMEI Eurípedes Simões de Paula), sendo uma entre as 1372 unidades que atendem a população da faixa etária entre 0 e 6 anos (dados de março de 2006, quantificavam esse atendimento em 329.515 crianças). Essas unidades de atendimento estavam assim divididas na cidade de São Paulo em 2006:

Quadro 1 - Unidades educacionais de Educação Infantil da PMSP.

\begin{tabular}{|l|l|}
\hline \multicolumn{1}{|c|}{ TIPO DE UNIDADE } & QUANTIDADE \\
\hline Escolas Municipais de Educação Infantil & 464 \\
\hline Centros de Educação infantil (administração direta pela PMSP) & 334 \\
\hline
\end{tabular}




\begin{tabular}{|l|l|}
\hline \multicolumn{1}{|c|}{ TIPO DE UNIDADE } & QUANTIDADE \\
\hline $\begin{array}{l}\text { Centros de Educação Infantil (administrados por entidades } \\
\text { filantrópicas recebendo através de convênios um subsidio da } \\
\text { PMSP para seu funcionamento) }\end{array}$ & 571 \\
\hline Centros de Educação Infantil Indígena & 3 \\
\hline
\end{tabular}

A rede de unidade educacionais do município estava na época da pesquisa e nos dias atuais, dividida em 13 agrupamentos regionais denominados Coordenadorias de Educação. Dados da Secretaria Municipal de Educação, referentes a março de 2006 informam que a Coordenadoria de Educação de Pirituba, da qual a unidade educacional faz parte, tinha no momento da pesquisa 98.596 crianças matriculadas, sendo 32.217 na educação infantil (de 0 a 6 anos) e desses, 26.772 especificamente nas unidade educacionais de educação infantil (EMEls) que totalizavam 41 nessa região.

Em 2006, a EMEI Eurípedes Simões de Paula atendia 538 crianças em 3 turnos parciais de 4 horas cada (das 7 às 11 horas, das 11 às 15 horas e das 15 às 19 horas).Havia apelos da população para que o atendimento se fizesse em período integral. Porém isso era inviável no momento da pesquisa devido a grande demanda da região por vagas (densidade populacional versus número de vagas disponíveis) e ao espaço físico que se apresentava inadequado para efetivação de um atendimento em período integral com qualidade.

A unidade educacional tem 20 anos de funcionamento. Em conversas informais com moradores do entorno, a pesquisadora obteve a informação de que a escola foi ali instalada após reivindicação popular, ocupando uma construção pública que estava destinada a um posto de atendimento médico.

Essa "adaptação" da estrutura para o atendimento às crianças, aliada à irregularidade do terreno na maior parte da área externa, o que inviabiliza a utilização pelas crianças,dada sua excessiva inclinação, traz grandes dificuldades em relação à distribuição e aproveitamento do espaço, comportando grande número de escadas de acesso às áreas de uso comum como o refeitório, a cozinha, os banheiros, o parque, uma dificuldade de comunicação entre os espaços externos e internos e pouca área externa para o número de alunos que freqüentam o espaço.

No total existem 5 salas destinadas ao atendimento das crianças que comportavam no período de realização deste estudo 16 agrupamentos já que 2 
agrupamentos do período da manhã ocupavam uma única sala em sistema de rodízio.

Os agrupamentos apresentavam-se divididos em arranjos etários de quatro, cinco ou seis anos, com um educadora responsável e uma média de 35 crianças matriculadas.

Das cinco salas existentes, três estavam com seus espaços reorganizados de maneira a contemplar mais adequadamente a execução da proposta pedagógica da unidade educacional e duas estavam em processo apenas inicial de reorganização ${ }^{22}$.

O prédio da unidade educacional em questão tem um piso reservado às áreas comuns e dois pisos superiores localizados um a esquerda e outro a direita da entrada onde se encontram as salas dos agrupamentos e a área destinada a gestão ${ }^{23}$, respectivamente.

\footnotetext{
${ }^{22}$ A organização espacial interna das salas está explicitada adiante, incluindo-se as mudanças realizadas pela intervenção da educadora neste espaço no transcorrer da investigação.

${ }^{23} \mathrm{~A}$ área destinada á gestão está detalhada na planta2 referente ao mesanino.
} 
Figura 4 - $\underline{\text { Croqui da EMEI Eurípedes Simões de Paula }}$

\begin{tabular}{|c|c|}
\hline \multicolumn{2}{|c|}{$\begin{array}{l}\text { Figura } 1 \text {-PISO INFERIOR } \\
\text { LEGENDA }\end{array}$} \\
\hline 1 & Sala informática e vídeo \\
\hline 2 & Sala dos agrupamentos \\
\hline 3 & Sala dos agrupamentos \\
\hline 4 & $\begin{array}{l}\text { Sala ocupada pelo } \\
\text { agrupamento onde } \\
\text { realizamos a pesquisa }\end{array}$ \\
\hline 5 & Sala dos agrupamentos \\
\hline 6 & Sala dos agrupamentos \\
\hline 7 & Estacionamento \\
\hline 8 & Área externa cimentada \\
\hline 9 & Banheiro infantil feminino \\
\hline 10 & Banheiro infantil masc. \\
\hline 11 & Palco coberto \\
\hline 12 & Galpão coberto \\
\hline 13 & Área do refeitório/mesas \\
\hline 14 & Quarto de vestir/adultos \\
\hline 15 & Banheiro adulto \\
\hline 16 & $\begin{array}{l}\text { Acesso escadas e área } \\
\text { externa }\end{array}$ \\
\hline 17 & Cozinha \\
\hline 18 & Dispensa de alimentos \\
\hline 19 & $\begin{array}{l}\text { Refeitório das prof. e } \\
\text { escadaria de acesso á } \\
\text { área administrativa do } \\
\text { piso superior }\end{array}$ \\
\hline 20 & Entrada 1 /escadaria \\
\hline 21 & Entrada 2 /escadaria \\
\hline 22 & Área cimentada externa \\
\hline 23 & $\begin{array}{l}\text { Parque de areia com } \\
\text { brinquedos fixos: } \\
\text { A) gangorra } \\
\text { B)trepa-trepa } \\
\text { C) escorregador peq } \\
\text { D) casinha do Tarzã } \\
\text { E) colméia de cimento } \\
\text { F) escorregador de } \\
\text { cimento } \\
\text { G)tanque de areia } \\
\text { H) trem de cimento }\end{array}$ \\
\hline
\end{tabular}

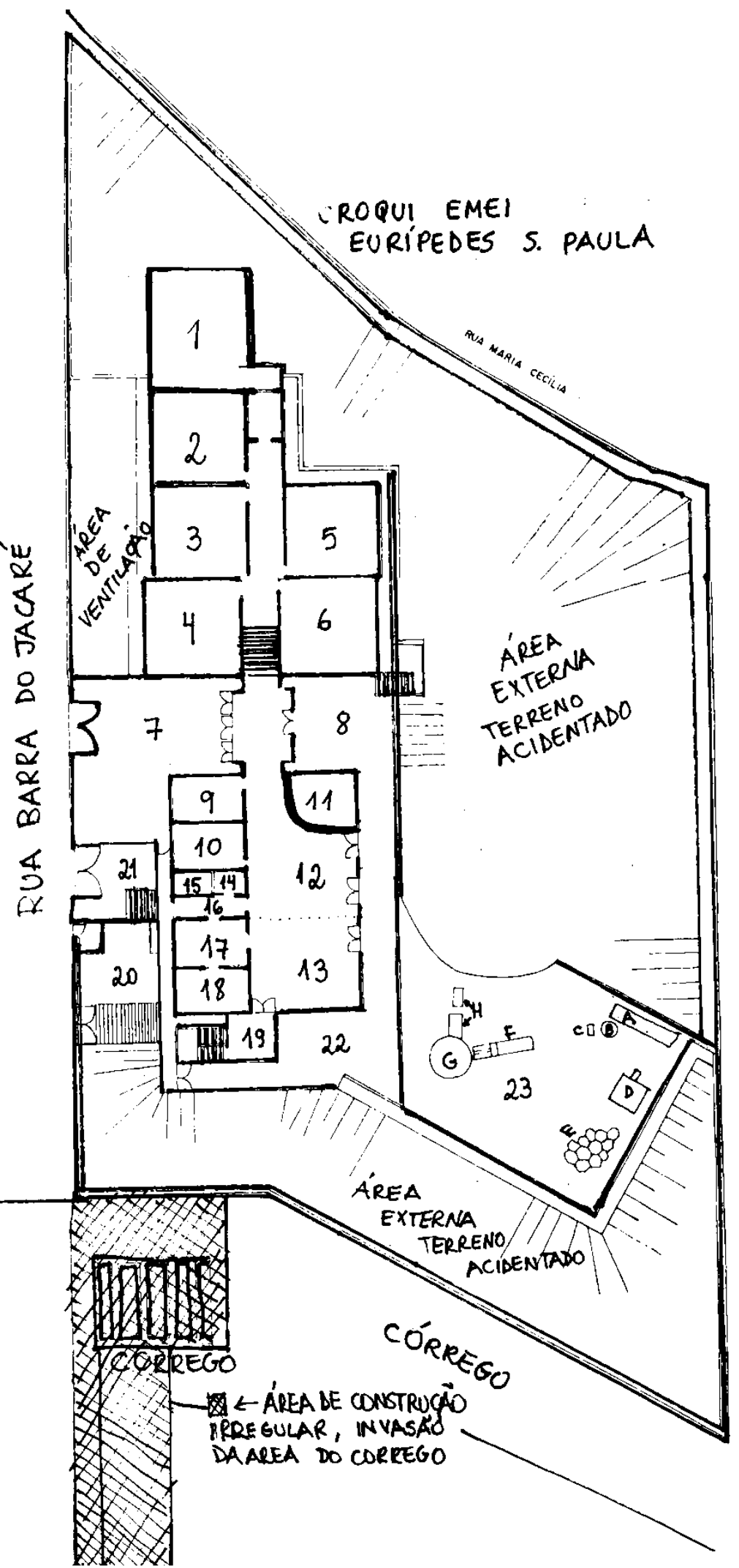


Observações:

- Devido a topografia inclinada do terreno, há escadas ligando as áreas 20 e 21 (entradas) a área comum da unidade educacional (7 a 23) .

- Na interligação das áreas comuns para as salas dos agrupamentos também há escadarias. $O$ acesso ao piso superior (área administrativa) também é realizado por 2 lances de escadas.

- O mezanino superior fica sobre as áreas números 9, 10, 14,16,16,17,18 e 19 do piso inferior

Figura 5 - Mezanino
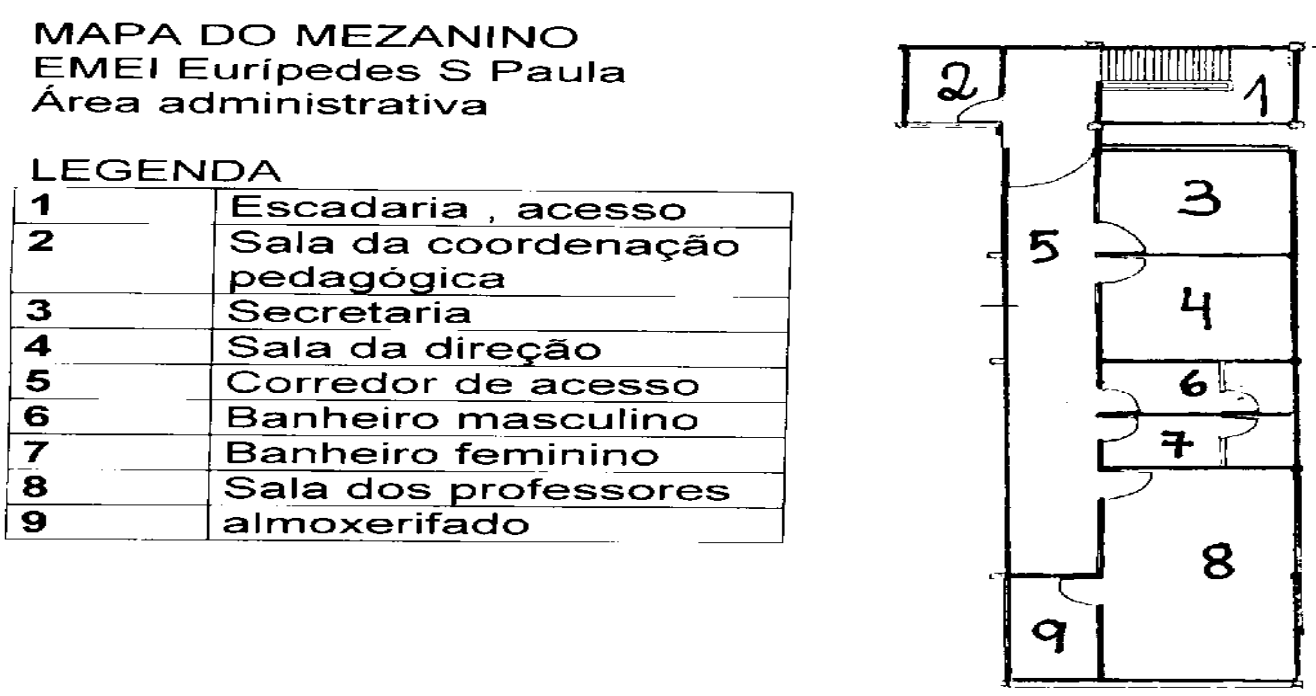

Durante o estudo empírico e até o momento atual, a unidade educacional contava com um corpo de educadores composto por uma diretora, uma coordenadora pedagógica, 16 educadoras responsáveis pelos agrupamentos e a equipe de apoio operacional com 12 profissionais.

Houve apoio da gestão para a realização da pesquisa, principalmente por parte da coordenadora pedagógica que atua na unidade educacional a época.

O agrupamento acompanhado era composto por 35 crianças que não tinham até o momento, passado por experiências em salas que aplicassem a proposta de Reorganização dos Espaços e das Atividades.

O agrupamento era assim configurado: 
Quadro 2 - Sexo das crianças

\begin{tabular}{|l|c|}
\hline SEXO & $\begin{array}{l}\text { QUANTIDADE DE } \\
\text { CRIANÇAS }\end{array}$ \\
\hline FEMININO & 15 \\
\hline MASCULINO & 20 \\
\hline
\end{tabular}

Quadro 3- Idade e escolaridade anterior das crianças

\begin{tabular}{|l|c|c|c|c|}
\hline \multirow{2}{*}{$\begin{array}{c}\text { IDADE DAS } \\
\text { CRIANÇAS }\end{array}$} & \multicolumn{2}{|l|}{$\begin{array}{l}\text { Não freqüentaram a unidade } \\
\text { educacional no ano de 2005 }\end{array}$} & \multicolumn{2}{|l|}{$\begin{array}{l}\text { Freqüentaram a unidade } \\
\text { educacional no ano de 2005 }\end{array}$} \\
\cline { 2 - 5 } & MENINOS & MENINAS & MENINOS & MENINAS \\
\hline $\begin{array}{l}5,8 \text { anos a } \\
5,11 \text { anos }\end{array}$ & 3 & 1 & 1 & 5 \\
\hline $\begin{array}{l}6 \text { anos a } \\
6,3 \text { anos }\end{array}$ & 6 & 2 & 1 & 3 \\
\hline $\begin{array}{l}6,4 \text { anos a } \\
6,7 \text { anos }\end{array}$ & 8 & 4 & 1 & $/$ \\
\hline
\end{tabular}

A educadora com a qual se estabeleceu parceria nesta pesquisa, tinha na época 28 anos e iniciou na docência, em 1997. Manteve, até 2002, vínculo como educadora de escolas particulares. Seu exercício profissional na Prefeitura do Município de São Paulo começou no ano de 2003, como professora de educação infantil, com carga horária de 30 horas (jornada especial integral-JEI), cargo que até hoje exerce na unidade em que a pesquisa se realizou.

Ainda na prefeitura, a partir de 2004 e até o momento, trabalha como educadora de Sala de Apoio Pedagógico (SAP) onde realiza atividades de acompanhamento e inclusão, atendendo crianças de 7 a 15 anos individualmente ou em grupos de até 6 crianças, que frequentam este espaço duas vezes por semana. Sua carga horária aqui também é de 30 horas semanais.

Possui graduação em Pedagogia e especialização em deficiência mental.

A parceria no processo de investigação-ação firmou-se graças à disponibilidade da educadora em participar do estudo, fato observado desde os contatos iniciais. O convívio com ela corroborou essa análise inicial, quando foi possível notar uma abertura para o novo, marcada pela perspicácia que demonstra 
diante da singularidade das crianças que estavam sob sua responsabilidade na unidade educacional.

Esse olhar para as características pessoais das crianças, suas necessidades e a predisposição da educadora para respeitar essa individualidade, fez com que a parceria estabelecida na pesquisa-ação tenha transcorrido de maneira muito tranquila e produtiva .

\section{2 - Procedimentos Metodológicos}

Este estudo situa-se no âmbito de um paradigma qualitativo porque incide sobre a análise de uma situação real, realizada em seu contexto natural tal como ele ocorre (YIN, 2005)

Segundo Gómez;Flores e Jiménez (1999) os investigadores qualitativos estudam a realidade em seu contexto natural, tal como acontece,tentando extrair-Ihe sentido, interpretando os fenômenos de acordo com os significados que eles tem para as pessoas envolvidas.

Biklen e Bogdan(1994) elencam cinco características da investigação qualitativa: 1) a fonte dos dados é o ambiente natural, constituindo o investigador o instrumento principal; 2) a investigação é descritiva, os dados assumem importância pelas possibilidades de maior compreensão do objeto de estudo; 3) os investigadores interessam-se mais pelo processo do que simplesmente pelos resultados ou produtos; 4) os dados são analisados de forma indutiva e não para comprovar hipóteses prévias, as abstrações são construídas à medida que os dados particulares que foram recolhidos vão se agrupando; 5) o processo de investigação reflete uma espécie de diálogo entre os sujeitos, dado estes não serem abordados de forma neutra.

Tratou-se de um estudo de caso único que pretendeu acompanhar e compreender a prática pedagógica de uma educadora ao longo do ano letivo de 2006, com um agrupamento de 35 crianças, numa Escola de Educação Infantil da Prefeitura do Município de São Paulo, que estava com seus espaços previamente reorganizados conforme o projeto pedagógico da unidade escolar ${ }^{24}$, acompanhando

\footnotetext{
${ }^{24}$ O projeto da unidade educacional foi citado com detalhes no capítulo 1 que tratou dos modelos e das propostas pedagógicas
} 
as alterações que ela realizou nesse espaço e em sua prática, e os efeitos desse processo de transformação nas crianças.

Gómez;Flores e Jiménez (1999) estabelecem que o estudo de caso permite compreender e clarificar uma determinada questão particular dentro de uma complexidade de eventos e de um contexto rico em nuances (como é o dia a dia da educação infantil ${ }^{25}$ ) e centra-se numa situação ou fenômeno concreto.

Segundo Gomez, Flores e Jiménez (1999) o estudo de caso implica um processo de indagação que se caracteriza pelo exame detalhado, compreensivo, sistemático e em e profundidade do caso que é objeto de interesse.

Para Yin (2005) o estudo de caso é definido como um estudo empírico que investiga um fenômeno contemporâneo dentro de um contexto da vida real, especialmente quando os limites entre o fenômeno e o contexto não estão claramente definidos ou onde não se pode manipular os comportamentos relevantes.

O caso único foi escolhido para analisar essas questões relacionadas à prática pedagógica e as situações que emergem do cotidiano considerando que a maneira que cada indivíduo usa para intervir em um contexto educativo é irrepetível e peculiar e uma análise mais profunda pode mostrar-se reveladora do percurso de construção dessa prática pedagógica e de seus desdobramentos. Além disso, este tipo de desenho investigativo possibilita à pesquisadora um acompanhamento mais efetivo e detalhado dos sujeitos envolvidos.

Acredita-se ser importante compreender a particularidade do caso e considera-se que a análise desse contexto em que a prática pedagógica ocorre dará indicações de caminhos possíveis de intervenção dessa educadora junto á criança, com vistas à melhoria da qualidade do processo educativo que ali se efetiva.

A pesquisa-ação foi selecionada como estratégia considerando-se que 0 processo de reflexão da prática docente é elemento fundamental para aprimoramento da qualidade da educação, conforme conceituada anteriormente neste trabalho no capítulo 3.

$\mathrm{Na}$ dinâmica escolhida os dados coletados e analisados em regime de cooperação entre a educadora e a pesquisadora dão indicadores das ações a serem implementadas. Conforme atesta Tripp (2005), quando cita que o processo cíclico de

\footnotetext{
${ }^{25}$ Nota da pesquisadora
} 
avaliação/planejamento/implementação, traz desdobramentos para a pesquisa e também para a ação desenvolvida acredita-se que esta parceria traga benefícios tanto para a pesquisadora no que se refere ao processo formativo da educadora, quanto para a educadora na sua atuação junto à criança.

Afirmam Gómez;Flores e Jiménez (1999) que quando pretendemos conceituar a pesquisa-ação, existe uma enorme diversidade de concepções, sendo impossível atualmente chegar a um conceito único dessa perspectiva de pesquisa porém , apontam algumas características coincidentes entre a maioria dos autores: a) nessa modalidade de pesquisa a ação é preponderante como método; b) ela não pode ser realizada de forma isolada necessitando sempre acontecer de forma grupal ou colaborativa; c) o pesquisador utiliza um método flexível, ecológico e orientado aos valores.

Sobre a pesquisa-ação em escolas, Elliott (2000,) elenca oito características fundamentais dessa modalidade de pesquisa que são: 1) ela analisa as ações humanas e situações vividas nas escolas se relacionando com problemas práticos; 2) tem como propósito a compreensão mais profunda, o diagnóstico de um problema; 3) adota uma postura exploratória na qual a ação para modificar uma situação fica suspensa até que se consiga uma compreensão mais profunda do problema prático em questão; 4) ao explicar o que ocorre no contexto real consideram-se as contingências mutuamente interdependentes; 5) interpreta-se "o que ocorre" do ponto de vista daqueles que atuam e interagem na situação do problema; 6)busca-se a utilização da linguagem dos envolvidos para explicar "o que ocorre" na prática; 7) é validada através do livre diálogo; 8) necessita do estabelecimento de um fluxo livre de informações entre todos os sujeitos.

A opção pela modalidade de pesquisa -ação derivou da possibilidade de serem atendidas as características essenciais deste tipo de estudo e ainda pela abertura e disponibilidade tanto da equipe gestora da unidade escolar onde a pesquisa teve lugar, quanto da educadora para o desenvolvimento da ação em regime de parceria.

Thiollent (2004) define a pesquisa-ação como pesquisa social de base empírica, realizada em estreita associação com uma ação ou com a resolução de um problema coletivo no qual os pesquisadores e participantes estão envolvidos de modo cooperativo ou participativo. 
Considerando esta dimensão da pesquisa—ação, Stake (1999) nos alerta que sempre que possível devemos escolher casos onde nossas indagações sejam bem acolhidas, onde tenhamos pessoas dispostas a colaborar e dar suas opiniões nos assuntos que tratamos.

Nesta pesquisa, a parceria com a educadora teve inicio em 2004, por ocasião de um encontro regional de educadores, onde três educadoras da EMEI Eurípedes Simões Paula, entre elas a pesquisadora, fizeram um relato do projeto de Reorganização dos Espaços e das Atividades que estava ocorrendo na unidade, com predomínio da brincadeira no espaço educativo. Nesse encontro a educadora Luciana teve oportunidade de conhecer a proposta do projeto, os avanços alcançados e as dificuldades que estavam presentes até aquele momento e mostrou-se interessada em vivenciar essa dinâmica de trabalho.

Em 2005, através da intermediação de colegas comuns, houve um encontro inicial, onde informalmente a educadora Luciana pode conhecer melhor a dinâmica de trabalho da escola, teve acesso ao projeto escrito da proposta de Reorganização dos Espaços e das Atividades e foi informada do interesse da pesquisadora em ter, como objeto de estudo, a prática de uma educadora na sala reorganizada. Nesse momento também tomou conhecimento inicial dos objetivos e procedimentos da referida pesquisa, bem como do período em que seria realizada (ano letivo 2006).

No final do ano letivo de 2005, a educadora Luciana decidiu experimentar a nova prática e ousou aceitar o desafio da pesquisa colaborativa. Removeu-se $\mathrm{e}^{26}$ então da outra unidade em que lecionava vindo para a EMEI Eurípedes Simões de Paula, onde optou pela ocupação de uma das salas que estavam com os espaços reorganizados para desenvolver seus trabalhos no ano de 2006.

A efetiva parceria na pesquisa teve inicio em fevereiro de 2006 , sendo a coleta de dados realizada entre março e dezembro de 2006.

Segundo Thiollent (2004) na pesquisa-ação há objetivos de conhecer a situação apresentada, mas também de propor soluções para os problemas apresentados ou pelo menos elucidá-los. É uma forma de experimentação em situação real na qual os envolvidos mudam conscientemente alguns aspectos desta

\footnotetext{
${ }^{26}$ O processo de remoção, previsto pela legislação municipal, permite que os educadores se candidatem anualmente para troca de unidade escolar onde prestam serviços. È levado em conta neste processo o número de vagas de cada unidade e a pontuação dos educadores, que é atribuída à partir do tempo de serviços prestados no município, bem como da titulação resultante dos cursos efetuados pelos educadores.
} 
situação pelas ações que decidiram aplicar. O autor afirma ainda (idem p.41 que "com a pesquisa-ação pretende-se alcançar realizações, ações efetivas, transformações ou mudanças no campo social“, porém alerta que tais mudanças são necessariamente limitadas pela permanência do sistema social como um todo, ou da situação geral.

As estratégias escolhidas para o acompanhamento e intervenção na prática pedagógica também levaram em conta essa perspectiva de colaboração e coautoria.

$\mathrm{Na}$ pesquisa a educadora Luciana, em parceria com a pesquisadora, escolheu e projetou as mudanças que realizou na sua ação junto às crianças, no espaço e nos materiais. Estas mudanças estiveram vinculadas aos dados coletados e estes eram analisados em consonância com todo o contexto ao qual se vinculam, porém com maior preocupação com o processo desenvolvido, seus desdobramentos, peculiaridades e possibilidades, do que com a classificação dos resultados obtidos (GÓMEZ;FLORES E JIMÉNEZ, 1999) .

Essa perspectiva de trabalho vai de encontro ao que se refere Thiollent (2004 p. 66) quando afirma que na pesquisa-ação " as ações investigadas envolvem produção e circulação de informação, elucidação e tomada de decisões e outros aspectos supondo uma capacidade de aprendizagem dos participantes.

A pesquisa desdobrou-se em dois eixos interdependentes e complementares de análise que configuram o desenrolar da prática pedagógica acompanhada.

O EIXO I tratou especificamente do trabalho desenvolvido pela educadora Luciana em 2006, numa sala de espaços reorganizados, e as alterações que ela foi realizando durante esse ano letivo tanto nos espaços e materiais quanto na sua prática docente. O foco principal esteve voltado para a educadora e seu percurso pessoal numa proposta pedagógica diferenciada.

As características da pesquisa-ação conforme apontadas por Thiollent (2004): a) ampla e explicita interação entre todos os envolvidos na pesquisa; b) previsão de ações concretas para interferência na situação; c) o objeto da investigação é uma situação social e os problemas de diferentes naturezas nela encontrados; d) tem o objetivo de resolver ou esclarecer a situação apresentada; e) há decisões partilhadas por todos os atores durante o processo; f) não se limita a ação, pretendendo também aumentar o conhecimento do pesquisador e o conhecimento ou nível de consciência dos envolvidos; serão mais claramente observáveis no 
EIXO I, justamente pela ocorrência da co-autoria no processo de transformação da prática educativa, através da reflexão conjunta educadora/pesquisadora. Os instrumentos de pesquisa refletem isso.

No EIXO 2, buscou-se verificar e compreender os efeitos da prática dessa educadora nas realizações do grupo de crianças. Essa análise foi realizada mediante utilização da Escala de Envolvimento da Criança -LIS-YC ,proposta por Ferre Laevers (1994 $)^{27}$. No EIXO 2 o foco principal portanto é a criança,pois se pretende através da observação de seu bem-estar e envolvimento, chegar a uma análise da prática pedagógica realizada pela educadora Luciana naquela unidade educacional em 2006.

Para cada eixo foram desenvolvidas estratégias específicas de coleta e análise dos dados que serão detalhados no capítulo 5 deste estudo.

No ano de 2006, quando a pesquisa foi realizada,tanto a pesquisadora como a educadora Luciana, atuavam como docentes na mesma unidade educacional. Porém, ao escolher a classe em que a pesquisa seria realizada optou-se deliberadamente por um agrupamento diverso daquele no qual a pesquisadora atuava como docente e ainda foi selecionada, entre as parceiras possíveis, uma educadora recém chegada na unidade escolar, com a qual não havia qualquer vínculo hierárquico ou de poder do ponto de vista trabalhista.

Os cuidados tomados são corroborados pelas análises que Franco (2005) faz sobre as pesquisas realizadas no próprio local de trabalho do pesquisador e tem como finalidade garantir o necessário distanciamento da pesquisadora do fato observado, e possibilitar maior confiabilidade dos resultados obtidos. Mergulhar no universo a ser pesquisado faz parte da proposta da pesquisa-ação porém os cuidados para que este fato não afetasse as análises foram tomados, entre eles a triangulação de fontes.

Nos dois eixos considerados na pesquisa, além do cuidado com o processo de coleta de dados, buscando a menor interferência possível na realidade observada, porém com clareza da impossibilidade da completa neutralidade da pesquisadora, um fator preocupante quando da análise e tratamento dos dados foi sua fidedignidade, pois a interpretação desses dados também exigiria exatidão e atribuição de significados pertinentes.

\footnotetext{
${ }^{27}$ as características desse instrumento estarão explicitadas no Capítulo 5, item 5.2 que vai tratar especificamente do eixo 2.
} 
Nessa perspectiva, optou-se pela dinâmica da triangulação. Sobre esta opção metodológica, afirma Stake (1999 p.94) que

"em nossa busca por precisão e explicações alternativas, necessitamos de
disciplina, necessitamos de estratégias que não dependam de simples
intuição e das boas intenções de "fazer bem". Na investigação qualitativa
estas estratégias se denominam triangulação."

$\mathrm{Na}$ perspectiva do autor a triangulação serve para revisão de nossas interpretações, para aumentar o crédito da interpretação e conseguir a necessária confirmação da análise realizada.

Denzin $(1984 ; 1989$, in Stake 1999) indica quatro tipos de triangulação possíveis na pesquisa qualitativa. A triangulação de fontes, a triangulação de investigadores, a triangulação de teorias e a triangulação metodológica.

A triangulação de fontes é, na pesquisa qualitativa, a estratégia que nos permite garantir a disciplina e a busca pela precisão dos dados que coletamos. Segundo Stake (1999 p.96): "assumimos que o significado de uma observação é uma coisa porém as observações adicionais nos servem de base para revisão de nossa interpretação".

Ainda Gómez;Flores e Jiménez (1999) encontramos que a triangulação tem permitido integrar e contrastar toda a informação disponível para construir uma visão global, exaustiva e detalhada de cada experiência particular, sendo a triangulação de informantes e sujeitos prática recomendável e essencial se pretende aproximar de um entendimento profundo da realidade que permite interpretações pertinentes dos dados coletados.

O quadro abaixo faz uma apresentação esquemática do processo de triangulação de fontes adotada neste estudo:

Quadro 4 - Triangulação de fontes

\begin{tabular}{|l|l|l|l|}
\hline \multirow{2}{*}{} & \multicolumn{3}{|c|}{ INFORMANTES E INSTRUMENTOS DE COLETA DE DADOS } \\
\cline { 2 - 4 } & \multicolumn{1}{|c|}{ PESQUISADORA } & \multicolumn{1}{c|}{ EDUCADORA } & \multicolumn{1}{c|}{ CRIANÇAS } \\
\hline EIXO 1 & -observação: diário de & -entrevistas & -comentários \\
PRÁTICA & campo, vídeos, fotos & -reuniões de tutoria com & âneos \\
PEDAGÓGICA & -reuniões de tutoria com a & a pesquisadora \\
& educadora & -auto-relato & \\
\hline
\end{tabular}




\begin{tabular}{|c|c|c|c|}
\hline & \multicolumn{3}{|c|}{ INFORMANTES E INSTRUMENTOS DE COLETA DE DADOS } \\
\hline & PESQUISADORA & EDUCADORA & CRIANÇAS \\
\hline $\begin{array}{l}\text { EIXO } 2 \\
\text { EFEITOS DA } \\
\text { PRÁTICA NAS } \\
\text { CRIANÇAS }\end{array}$ & $\begin{array}{l}\text { - análise do envolvimento da } \\
\text { criança } \\
\text { - observação: diário de } \\
\text { campo, vídeos, fotos }\end{array}$ & $\begin{array}{l}\text { - análise do } \\
\text { envolvimento da criança }\end{array}$ & $\begin{array}{l}\text { - filmagem para } \\
\text { aplicação da escala de } \\
\text { envolvimento da criança } \\
\text { - fotos }\end{array}$ \\
\hline
\end{tabular}

A triangulação metodológica defendida por Denzin (1984) foi muito utilizada nesta pesquisa quando se buscou completar as observações realizadas com outras formas de coleta de dados advindas de outras fontes, formando assim um panorama, que se pensa menos subjetivo, da realidade observada.

A triangulação da teoria, onde vários investigadores comparam seus dados e suas análises foi particularmente útil para atribuir o escore de envolvimento da criança, realizou-se em conjunto com outros pesquisadores algumas reuniões de treinamento para uso da escala ocorridas antes do uso desta e várias análises de episódios coletados pela pesquisadora em vídeo, que foram submetidos ao conjunto de pesquisadores habituados a utilizar o mesmo instrumento em suas pesquisas.

Este estudo objetivou a diminuição de possíveis arestas existentes entre a proposição teórica de Laevers(1994;2000) para o uso da escala de envolvimento da criança e seu emprego adequado na situação real de pesquisa.

Na perspectiva da pesquisa-ação, optou-se pela metodologia de peer-tutoring ou tutoria entre pares/ tutoria entre iguais. Topping y Ehly1998(in Duran, D 2002) dizem que: "podemos definir a tutoria entre iguais como interações entre pares de pessoas pertencentes a grupos sociais similares que aprendem ensinando-se porém onde nenhuma delas atua como educadora profissional da outra".

O "peer-tutoring " ou tutoria entre pares é, segundo Duran (2002), utilizada em muitos países, em muitos níveis educativos e áreas curriculares. Afirma ainda o autor que é recomendado por órgão especialista em educação $\left(\right.$ UNESCO ${ }^{28}$ ) $\mathrm{Como}$ prática altamente efetiva para a educação inclusiva.

Em pesquisas realizadas foi encontrada vasta bibliografia da perspectiva de peer-tutoring relacionada á educação inclusiva, á formação de profissionais ligados á área da saúde como medicina e enfermagem e particularmente nos EUA, esta

\footnotetext{
${ }^{28}$ UNESCO: Organização das Nações Unidas para a Educação, a Ciência e a Cultura
} 
dinâmica estava, na maioria das vezes, relacionada ao ensino superior, especialmente durante os anos iniciais da graduação.

Cabe enfatizar a perspectiva aqui adotada visto existirem múltiplas possibilidades de tutoria. A diferença entre a tutoria entre pares que se estabelece com os alunos passa pela definição de Melero e Férnandez (1995) quando esta é considerada um sistema de instrução constituído por uma díade onde um membro ensina a outro algo decorrente de um planejamento estipulado anteriormente, que tem por objetivo o auxílio para a aprendizagem de algum conteúdo ou ação específica.

No caso desta pesquisa as decisões não estavam tomadas a priori, não existia um modelo prévio já articulado e objetivos estipulados que se deveria atingir. O processo foi construído, sempre sendo alterado pela necessidade da ação ou pelo desejo dos indivíduos que nela estavam envolvidos.

A pesquisa-ação, nessa perspectiva de tutoria, foi gerando progressivo mergulho na realidade, com aprimoramento das observações tanto da pesquisadora quanto da educadora, fazendo surgir a necessidade de reflexões e intervenções nem sempre previstas no início do processo.

A parceria na pesquisa fez com que houvesse planejamento conjunto da atividade a ser realizada cooperativamente, atuação neste sentido e avaliação do desenvolvimento desta ação, pois a intervenção cooperada exige que haja o propósito de partilha, propósito este que se explicita em ações, acordos e em objetivos comuns.

As ações conjuntas, particularmente as atividades que denominamos de reuniões de tutoria, em que a educadora e pesquisadora discutiam a prática pedagógica desenvolvida e seus efeitos nas crianças constituíram uma rede de interações horizontais, como uma sinfonia que se efetiva a quatro mãos. Este desvelar da prática, que partia da reflexão e se expressava pela linguagem é, segundo Oliveira-Formosinho (2002 c) a única maneira de acessar o processo de construção de significados pelo adulto.

Pensando em formação,

pode-se dizer, com inspiração em Bronfenbrenner (1979) que a ecologia do desenvolvimento profissional dos educadores envolve o estudo do processo influenciado pelas inter-relações tanto entre os contextos mais imediatos quanto em contextos mais vastos em que a educadora interage (OLIVEIRAFORMOSINHO 2002 c, p.51) 
Nessa visão ecológica de desenvolvimento profissional, entende-se que a parceria é imprescindível pois muitos educadores tem dificuldades para transpor a teorização e dialogar com suas práticas, ao mesmo tempo em que se apresenta muito comum a dificuldade dele olhar reflexivamente a teoria a partir de sua prática. Esta aparente "desconexão" gera discursos brilhantes e práticas pobres.

Duran (2002) afirma que na tutoria entre os pares, ambos aprendem. O tutorado pela ajuda permanente que recebe de seu companheiro tutor e este pela atividade de preparação e oferecimento de ajuda pedagógica a seu tutorado, que lhe permitirá um nível mais profundo de domínio do conteúdo.

Miquel(2003) enfatiza que o trabalho conjunto entre os docentes também pode oferecer oportunidades de desenvolvimento profissional. A tutoria entre pares é fonte de aprendizagem em si mesma. A partir da discussão conjunta e construtiva se mobilizam estruturas internas de cada participante, provocando mudanças no próprio conhecimento tanto no nível conceitual, quanto procedimental e atitudinal, é dizer que se constroem aprendizagens.

Corroborando o que foi colocado até aqui, vale ressaltar que quando pensamos em um processo formativo junto à educadora Luciana, a perspectiva que elegemos é o da formação em contexto onde:

[...] de desenvolvimento profissional é um processo vivencial, não puramente individual.... o desenvolvimento profissional conota uma realidade que se preocupa com os processos (levantamento de necessidades, participação dos professores na definição da ação), os conteúdos concretos aprendidos (novos conhecimentos, novas competências), os contextos da aprendizagem (formação centrada na escola), a aprendizagem de processos (metacognição), a relevância para as práticas (formação centrada nas práticas) e o impacto na aprendizagem dos alunos. (OLIVEIRAFORMOSINHO 1998 in 2002 d, p.6).

Nesse processo de parceria pesquisadora-educadora, a tipologia da intervenção poderia ser compreendida nos moldes que Oliveira Formosinho (2002 d, p.27) classifica como " uma intervenção co- operada (operada conjuntamente) o que implica, necessariamente, co-laboração (laboração conjunta). Assim, essa intervenção não é imposta de cima para baixo (top-down)nem de fora para dentro".

A crença da pesquisadora nesse tipo de processo foi, desde o início corroborada pela própria educadora Luciana. Na primeira entrevista ela menciona:“o 
fato de ter alguém assim perto foi o que mais me atraiu. A proposta eu gostei bastante, mas ter alguém que vai acompanhar, que vai sei lá conversar a respeito da sua sala, eu achei mais interessante."29

Na realidade da PMSP o coordenador pedagógico, a princípio um parceiro do professor para discussão do trabalho pedagógico realizado junto as crianças, quase nunca exerce plenamente essa função. No caso da escola pesquisada, uma diretora nova, sem experiência e com pouca clareza dos reais objetivos da educação infantil acabava por sobrecarregar a coordenadora pedagógica com funções burocráticas. Esta por sua vez, acabava mantendo-se mais distante do trabalho pedagógico, exercendo esse papel apenas de maneira mais coletiva ( nas reuniões bimestrais de educadoras, na organização das festas e eventos,na preparação da reunião de pais, etc.).

Esse distanciamento do coordenador pedagógico é fator generalizado na cultura institucional da educação infantil do município, sendo a sensação de "isolamento" uma queixa muito comum das educadoras.

$\mathrm{Na}$ pesquisa, a educadora Luciana reforçava o prazer que a proposta de parceria lhe inspirava, justificando que sempre se sentiu muito sozinha. Analisando a ação das coordenadoras pedagógicas de uma maneira mais geral diz:

[...]é muito interessante na rede, que grande problema é que até o coordenador tem medo de entrar na sala de aula. Não sei qual o problema mas ele parece que tem medo de entrar na sala de aula. Alguns professores não gostam e nunca o coordenador vai na sua sala, então o coordenador nunca sabe sa $^{30}$

Ele sabe assim do que você conta, do que você está vendo e ele só consegue dar uma opinião em cima do que você está falando.Ele nunca nem viu (os alunos ${ }^{31}$ ) ${ }^{32}$.

Percebemos que as críticas da educadora à estrutura da instituição, que acaba por desobrigar a coordenadora pedagógica de sua função, vinham mais de uma necessidade real do que de oposição à pessoa da coordenadora que atuava na escola. Vale ressaltar que, a princípio, o acompanhamento da prática pedagógica é

\footnotetext{
${ }^{29}$ Entrevista com a professora Luciana realizada em 12/02/06

30 Entrevista com a professora Luciana realizada em dezembro de 2006.

31 De acordo com o teor da fala, a educadora referia-se as crianças.

${ }^{32}$ Entrevista com a professora Luciana realizada em dezembro de 2006.
} 
função prioritária deste profissional de acordo com o próprio código que rege a estrutura do ensino municipal ${ }^{33}$ )

Os objetivos da tutoria entre pares na pesquisa foram: 1) a reflexão da educadora e da pesquisadora sobre a congruência entre suas próprias crenças e suas ações; 2) que a educadora se percebesse autora de sua própria prática pedagógica e agente dos efeitos desta prática que atingem a criança; 3) que a prática fosse percebida com certo estranhamento, o que possibilitaria ações de transformação junto ao que não fosse considerado adequado; 4) que a pesquisadora assumisse um papel de aprendente frente ao próprio processo de pesquisa qualitativa e co-autora das transformações ocorridas na realidade.

Jhonson, Jhonson e Holubec(1999) consideram que o que faz o processo de cooperação funcionar é perfeitamente aplicável ao conjunto de aprendizagens da tutoria entre pares. Segundo os autores, são cinco estes aspectos:

1) Interdependência positiva (o êxito de cada membro afeta o grupo/parceiro e vice-versa). Isto envolve saber que todos aprendem, dividir informações e materiais e ainda assumir papéis complementares faz parte deste processo.

2) Interações cara-a -cara. As oportunidades de interação devem permitir dinâmicas interpessoais de ajuda, assistência, suporte, encorajamento e reforço aos outros membros.

3) Responsabilidade individual- dentro do grupo/par deve-se assumir responsabilidades pessoais

4) Habilidades sociais: desenvolvimento de habilidades necessárias à cooperação como a comunicação apropriada, a resolução construtiva de conflitos, a participação e a aceitação do outro.

5) Auto-reflexão - os membros da tutoria (pares/grupo) refletindo conjuntamente sobre o processo de trabalho em função dos objetivos deste trabalho, pensando decisões de ajuste e melhoria.

No processo de parceria, instalado nesta pesquisa, buscou-se manter a clareza de que as efetivas mudanças na prática só podiam ser feitas pela educadora. Essa escolha lhe pertencia e somente a ela dizia respeito em primeira instância. Porém, na perspectiva da pesquisa-ação da tutoria entre pares, a

${ }^{33}$ A descrição das atribuições do Coordenador Pedagógico consta na Portaria 1971/98. Capítulo 2 , subseção III- artigos 37 e 38, e também em outros documentos da PMSP. 
pesquisadora apontava nos momentos de formação novas possibilidades de reflexão, de interpretação da prática e a possibilidade de caminhos variados, estimulando a educadora a fazer o mesmo processo reflexivo.

As análises ${ }^{34}$ indicam que esse olhar envolvido e reflexivo de ambas, gerava um processo real de co-autoria na transformação da realidade e de transformação de ambas, cada uma a seu modo, isto não é um motivo de surpresa, visto que há tempos a teoria histórico-cultural vem nos dizer da capacidade de um indivíduo para atuar como mediador do processo de construção de conhecimentos de seu par (VYGOTSKY 2000)

\footnotetext{
${ }^{34}$ As análises do estudo empírico encontram-se no capítulo 5 deste trabalho
} 
CAPÍTULO 5

ANÁLISE DOS RESULTADOS 
Neste capítulo serão apresentados os dados obtidos a partir da realização do estudo empírico em que se desenvolveram dois eixos de análise da transformação da prática pedagógica. O EIXO I relaciona-se ao processo de formação e o EIXO II, ao envolvimento das crianças nas atividades.

\subsection{EIXO 1 - Prática pedagógica: estudo sobre o processo de formação}

A prática pedagógica foi acompanhada de março a novembro de 2006. Os instrumentos metodológicos para este acompanhamento foram entrevistas, encontros de tutoria e observações de campo.

Uma das estratégias utilizadas nesse eixo foi a entrevista. Sabe-se que a entrevista não é uma ferramenta neutra e sim influenciada pelo pesquisador que a realiza, mas justamente pela consciência desse inconveniente buscou-se minimizar essa interferência, obedecendo a procedimentos de distanciamento e postura adequada durante a realização das mesmas (Stake, 1999, Bogdan, 1994, Gómez, 1999).

Segundo Gómez, Flores e Jiménez (1999, p. 168) "a entrevista é um dos meios para acessar o conhecimento, as crenças, os rituais, a vida dessa sociedade ou cultura, obtendo dados na própria linguagem dos sujeitos".

Optou-se pela realização de entrevistas semi-estruturadas, objetivando colher informações que pudessem, junto com outras fontes, acessar, em alguma medida, os significados que estavam sendo construídos pela educadora a respeito de sua prática pedagógica e auxiliar na definição dos processos de parceria possíveis e pertinentes à pesquisa-ação em desenvolvimento.

Bogdan e Biklen (1994, p. 135) destacam que

As entrevistas qualitativas variam de acordo com o grau de estruturação [...] mesmo quando se utiliza um guião, as entrevistas qualitativas oferecem ao sujeito a oportunidade de moldar seu conteúdo de forma demasiadamente rígida, quando o sujeito não consegue contar sua história em termos pessoais, em suas próprias palavras, a entrevista ultrapassa o âmbito qualitativo.

Antes da realização das entrevistas foram tomados alguns cuidados, como a discussão com outros pesquisadores sobre essa dinâmica e sobre autores e textos 
que analisam esse procedimento. Realizaram-se entrevistas-piloto com educadores pertencentes a contextos diferenciados daquele onde a pesquisa se realizava e houve elaboração prévia de protocolos de coleta de dados, além de revisão de bibliografia sobre o tema.

Nas entrevistas com uma educadora foram esclarecidos os objetivos da pesquisa e da entrevista e também os procedimentos de coleta de dados utilizados nesse processo, objetivando estabelecer um clima de confiança e cooperação entre a educadora e a pesquisadora. Outro cuidado relacionou-se à fidedignidade dos dados coletados, geralmente gravados e transcritos.

A opção pela transcrição e análise de conteúdo logo após a realização da entrevista está de acordo com a perspectiva proposta por Bardin (1977), que dá claras indicações sobre cuidados necessários com dados coletados por esse procedimento metodológico.

Realizaram-se cinco entrevistas com a educadora, semi-estruturadas, com duração média de 45 minutos. Essas entrevistas relacionaram-se diretamente com as questões da prática pedagógica e seus efeitos sobre as crianças, bem como sobre expectativas e dificuldades encontradas no processo de implantação da proposta de reorganização dos espaços e atividades.

As entrevistas versaram sobre os seguintes temas:

Quadro 5: Entrevistas com a educadora

\begin{tabular}{|c|l|}
\hline Data & \multicolumn{1}{|c|}{ Temas } \\
\hline 12.02 .2006 & $\begin{array}{l}\text { Acervo de brinquedos da classe, organização espacial, expectativa de } \\
\text { educadora quanto à prática pedagógica, reação das crianças. }\end{array}$ \\
\hline 27.04 .2006 & Encaminhamento dos trabalhos, principais avanços e dificuldades. \\
\hline 14.06 .2006 & Eleição dos sujeitos a acompanhar na análise do envolvimento. \\
\hline 03.08 .2006 & $\begin{array}{l}\text { Avaliação: proposta, trabalhos realizados, atuação da educadora, } \\
\text { desempenho das crianças. }\end{array}$ \\
\hline 20.12 .2006 & $\begin{array}{l}\text { Avaliação: proposta pedagógica, processo de pesquisa da prática } \\
\text { pedagógica e efeitos sobre as crianças. }\end{array}$ \\
\hline
\end{tabular}


Essas entrevistas estão transcritas, acompanhadas por análises de conteúdo e com redução dos dados. Nos anexos 1 e 2 contam, a título de exemplo, as entrevistas realizadas em 12/02/06 e 20/12/06 respectivamente.

Utilizou-se também a técnica de observação participante para acompanhar as atividades desenvolvidas em sala. Essa opção derivou da possibilidade de parceria estabelecida com a pesquisa-ação.

Para Gómez, Flores e Jiménez (1999, p.165) a observação participante pode ser definida como

Um método interativo de coleta de informações que requer um envolvimento do observador nos acontecimentos ou fenômenos que está observando. $O$ envolvimento ${ }^{35}$ supõe participar na vida social e dividir as atividades principais que realizam as pessoas que formam parte de uma comunidade ou instituição.

Stake (1999, p. 60) afirma que num estudo de caso "as observações conduzem o investigador a uma melhor compreensão do caso [...] escolhemos as oportunidades que os temas nos indicam em parte, e que nos ajudam a familiarizarmos melhor com o caso".

Nesse estudo as observações foram semanais, tendo como registro as notas de campo, gravações em vídeo e fotos, alternadas de acordo com o tema observado ou a necessidade de dados para o processo de reflexão da prática pedagógica. De acordo com cada aspecto que se mostrava relevante na análise da prática pedagógica foi elaborado um protocolo de observação prévio.

As observações tiveram duração média de 1 hora e 30 minutos e incluíam o momento de chegada das crianças na sala reorganizada, a roda de conversa e as atividades livres ou dirigidas que ali ocorriam até o horário em que se iniciava o lanche. Considera-se essa escolha de horários pertinente por ser, dentro da rotina diária, o momento em que se realizam simultaneamente as atividades orientadas pela educadora e as de livre escolha da criança. Comporta, ainda, atividades de grande grupo (roda de conversa, jogos etc..), de pequenos grupos orientados (atividade selecionada pela educadora) e atividades livres onde o protagonismo é da criança.

${ }^{35}$ No texto original a tradução do termo poderia ser considerada como ato de implicar-se, comprometer-se. 
$\mathrm{Na}$ realização das observações buscou-se seguir as indicações de Gómez; Flores e Jiménez (1999, pp. 61-63) relativas ao comportamento do observador, maneira de descrever os fatos observados e cuidados com os registros, tais como: a) manter-se centrado nos acontecimentos chaves; b) atento aos antecedentes que podem influir em análises posteriores; c) estabelecer relações entre os diferentes episódios para formar uma descrição única do caso, entre outros.

Para poder minimizar os efeitos da interferência da pesquisadora no momento da foto ou filmagem durante a situação observada (Bogdan, 1994), optou-se por incluir antes do início dessas observações (durante três encontros) a presença da pesquisadora nas atividades da sala. Foram apresentados os instrumentos tecnológicos que seriam usados (câmera fotográfica e filmadora), para que as crianças pudessem habituar-se a sua presença naquele espaço e com os instrumentos ali inseridos, de maneira que sua influência fosse pelo menos atenuada.

Foram realizados no total 28 períodos de observação, divididos segundo os objetivos elencados para cada um dos dois eixos deste estudo empírico.

Quadro 6 - Cronograma de observações

\begin{tabular}{|l|l|l|}
\hline \multirow{2}{*}{ Mês } & \multicolumn{2}{c|}{ Dias de Realização das Observações } \\
\cline { 2 - 4 } & Eixo 1 - Prática Pedagógica & Eixo 2 - Envolvimento das crianças \\
\hline Março & 15 e 23 & \multicolumn{1}{c|}{- - } \\
\hline Abril & 15 & 14 e 26 \\
\hline Maio & 03 e 25 & 17 \\
\hline Junho & 28 & 21 \\
\hline Julho & 27 & \\
\hline Agosto & 16,17 e 24 & 30 \\
\hline Setembro & $04,05,06$ e 27 & 12 e 19 \\
\hline Outubro & 05 e 31 & 18 \\
\hline Novembro & & $13,16,17$ e 21 \\
\hline
\end{tabular}

As observações da prática pedagógica foram registradas por meio de notas de campo, filmagens e fotos das ações da educadora e das crianças, bem como a recolha de material produzido pelas crianças no período de acompanhamento da pesquisadora. As observações relacionadas ao envolvimento da criança nas 
atividades seguiram protocolos próprios de coletas de dados (Laevers, 1994), mais detalhados no Eixo 2.

Um procedimento estabelecido espontaneamente entre a pesquisadora e a educadora Luciana, após cerca de dois meses do início da pesquisa, foi a realização de uma análise sucinta dos acontecimentos que haviam ocorrido no dia da observação participante, logo após esta. Avaliamos que essas trocas, apesar de seu caráter informal, enriqueceram muito as possibilidades de intervenção da pesquisadora no processo de formação/tutoria.

Outro procedimento de coleta de dados, associado à perspectiva de formação da educadora e reflexão da prática pedagógica, foi denominado como "encontros de tutoria".

Os "encontros de tutoria" contaram com a presença da educadora e da pesquisadora e versaram sobre questões relacionadas à prática pedagógica na perspectiva da construção progressiva da qualidade do atendimento. Eles tiveram periodicidade variável entre 15 e 25 dias e duração média de 45 minutos.

Nesses momentos foram revelados aspectos advindos das observações da pesquisadora, bem como, e prioritariamente, relacionadas pela educadora situações de sua prática que a sensibilizaram (positiva ou negativamente) para escolha das ações que serviam de objeto de análise conjunta da prática pedagógica. Também nessas reuniões geralmente eram estabelecidos os passos seguintes a serem executados pelos envolvidos, para melhoria da qualidade de observação (pela pesquisadora) ou da intervenção ou alteração da prática pedagógica (pela educadora).

Os encontros evidenciavam para as parceiras envolvidas quais os temas de observação posteriores que seriam acompanhados para gerar o prosseguimento e aprofundamento do processo reflexivo sobre a prática pedagógica. Os encontros de tutoria tiveram sempre a perspectiva formativa. Os temas vinham como decorrência das observações da pesquisadora sobre a prática pedagógica desenvolvida e também dos questionamentos da própria educadora, que se detinha na análise dos caminhos que escolhia para trabalhar com as crianças dentro da proposta pedagógica de Reorganização dos Espaços e das Atividades.

Em alguns desses encontros, também foram usadas filmagens e fotos, que assumiam, então, a perspectiva de desencadeadoras do processo reflexivo ou de facilitadoras da coleta de mais dados durante a entrevista. As imagens foram 
transformadas de pontos finais que demonstrariam uma prática a ser avaliada como adequada ou inadequada, em pontos de partida que objetivavam aprofundar o olhar sobre as práticas, buscando a melhoria do trabalho realizado junto às crianças. As imagens tornaram-se assim ferramentas da pesquisa, pois formavam um conjunto valoroso de dados, ricos e afinados com todo o processo de observação (Bogdan, 1994).

Foram realizados 13 encontros de tutoria. Os principais temas abordados foram os seguintes:

Quadro 7 - Cronograma das Reuniões de Tutoria

\begin{tabular}{|c|l|}
\hline Data & \multicolumn{1}{c|}{ Principais Temas } \\
\hline $\mathbf{0 6 . 0 2}$ & $\begin{array}{l}\text { Conversa inicial sobre a proposta pedagógica da unidade, espaços e } \\
\text { materiais disponíveis, processo de pesquisa }\end{array}$ \\
\hline $\mathbf{0 1 . 0 3}$ e 14.03 & $\begin{array}{l}\text { Organização dos encontros, dificuldades e facilidades encontradas pela } \\
\text { professora no desenvolvimento da proposta pedagógica }\end{array}$ \\
\hline $\mathbf{0 5 . 0 4}$ & $\begin{array}{l}\text { Envolvimento da criança na atividade (perspectiva teórica), avaliação do } \\
\text { andamento dos trabalhos }\end{array}$ \\
\hline $\mathbf{1 0 . 0 5}$ e 24.05 & $\begin{array}{l}\text { Dificuldades de organização dos materiais pela criança e intervenções } \\
\text { possíveis }\end{array}$ \\
\hline $\mathbf{1 4 . 0 6}$ e 21.06 & $\begin{array}{l}\text { Seleção dos sujeitos para análise do envolvimento, dificuldades com a } \\
\text { produção artística espontânea (pintura livre) realizada no cantinho das } \\
\text { artes e intervenções possíveis }\end{array}$ \\
\hline $\mathbf{1 0 . 0 8 ~ e ~ 1 7 . 0 8}$ & Barulho do ambiente e o processo de intervenção \\
\hline $\mathbf{3 0 . 0 8}$ & Regras e postura da educadora \\
\hline $\mathbf{2 2 . 0 9}$ & Roda de conversa, dificuldades e possibilidades \\
\hline $\mathbf{1 9 . 1 0}$ & Envolvimento e variação das atividades trabalhadas \\
\hline
\end{tabular}

A perspectiva de formação pensada pela pesquisadora para esses momentos pode ser representada pelo seguinte esquema: 
Figura 6 - Processo de tutoria entre pares

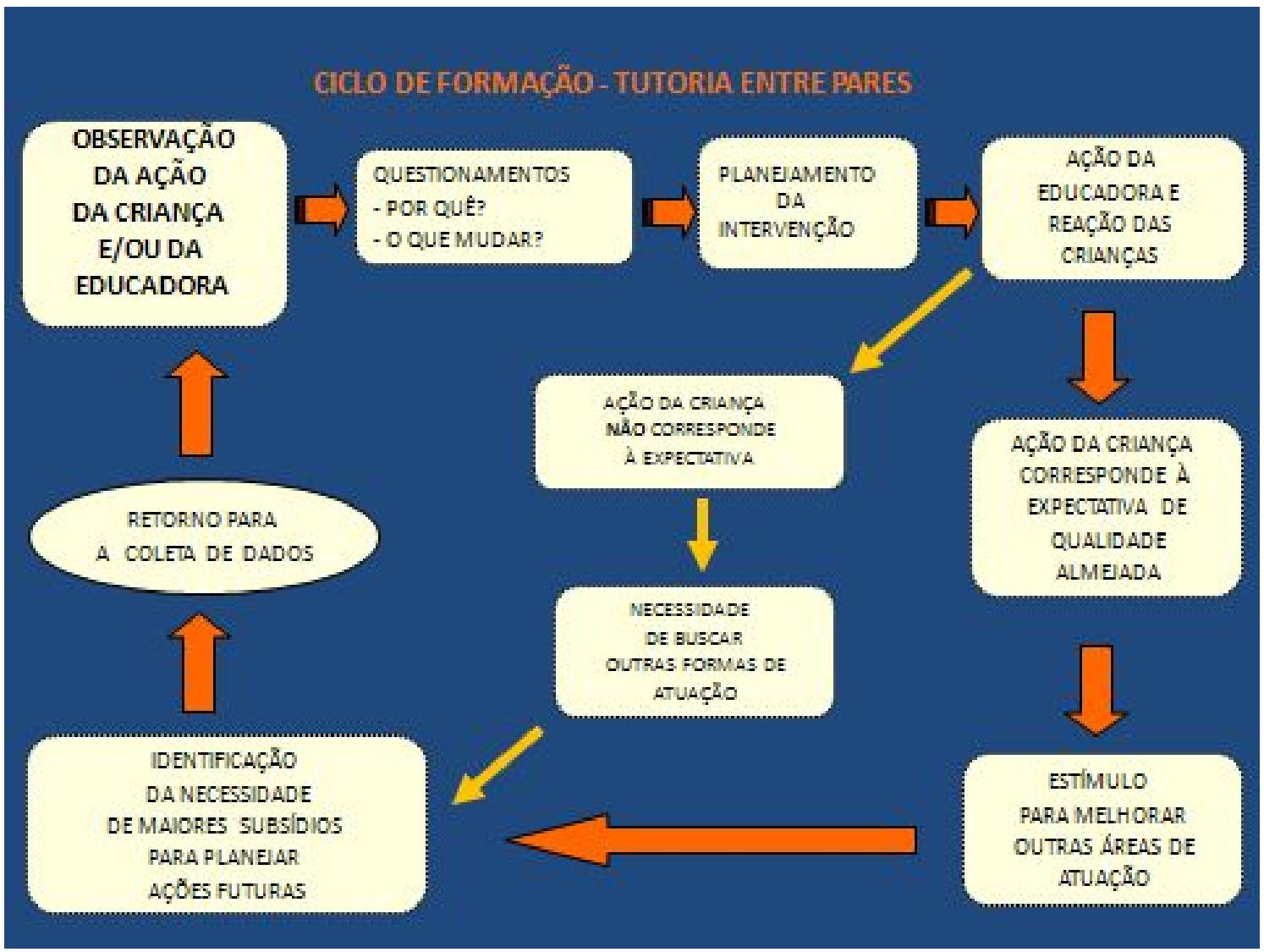

Para instigar a reflexão da educadora e da pesquisadora a respeito da prática pedagógica desenvolvida e seus efeitos nas crianças, bem como da necessidade de alterações no desenvolvimento das ações educativas, eram utilizados registros em vídeo, fotos, notas de campo da pesquisadora e análises da educadora.

Predominava a discussão conjunta da situação apresentada, num caminho reflexivo de desconstrução e reconstrução de concepções e práticas.

Desde o início do processo foi marcante a disponibilidade da educadora para o trabalho com a nova proposta pedagógica e também com a pesquisadora no processo de tutoria. As reflexões desencadeadas na revisão das práticas eram por ela aprofundadas, num exercício pessoal que se percebeu contínuo, com vistas à melhoria progressiva do atendimento das crianças sob sua tutela. Um fator preponderante em sua prática foi a disposição para incluir o novo: a partir da reavaliação do trabalho, realizou intervenções na ação, acompanhando os 
resultados e investindo em novas possibilidades de atuação - conteúdos, práticas, rotinas, posturas.

Foi particularmente significativa para 0 processo de pesquisa a disponibilidade que a educadora demonstrou para realização de algumas "tarefas", tais como registros pessoais, leituras acordadas nos momentos de formação, presença nas reuniões com a pesquisadora, entre outras.

Pascal e Bertram (1996, p. 75, In Oliveira-Formosinho \& Kishimoto, orgs., 2002) chamam a atenção para que o empenho do adulto é condição para seu desenvolvimento e qualidade dos serviços educacionais que presta à criança .

Garmston, Lipton e Kaiser (2002) lembram que, quer verbalizem ou não, os educadores alimentam crenças profundas sobre seu trabalho, seus alunos, papel da unidade educacional na sociedade, o currículo, o ensino e a aprendizagem. Essas crenças constituem fortes indicadores dos comportamentos futuros, influenciando percepções, decisões e ações de todos os atores da cena educativa. Segundo os autores, crenças são formadas muito cedo e tendem a perpetuar-se.

Quando se referem ao processo de construção de significados no adulto, os autores dizem que a soma da construção de significados de um educador reside internamente (em nível consciente e inconsciente) e serve como critério para suas percepções, decisões e comportamentos. Apenas quando é dada forma a esses significados através da linguagem é que eles se tornam acessíveis a ambas as partes (nessa transação verbal) e só então significados, percepções, decisões e comportamentos que deles derivam podem ser refinados, enriquecidos e modificados (Ibidem, p. 82).

Concordando com esta perspectiva, avaliou-se que o papel da pesquisa participativa, relacionado à tutoria, apresentou-se como alternativa muito interessante para essa desconstrução de significados pela própria educadora. Em vários comentários ela deixou claro quanto julgava significativas as observações e os questionamentos da pesquisadora sobre as ações realizadas (tanto da criança quanto dela própria).

Acreditamos que não foi a parceria em si ou esta outra pessoa (pesquisadora) que poderia ter modificado a ação da educadora, mas sim esse processo mediado de re-significar práticas a partir da reflexão conjunta. Isso foi significativo a ponto de desencadear, ou melhor, amplificar um processo que é, sobretudo, pessoal. Diz Garmston (2002, p. 87) 
Dado que a estrutura de superfície reflete a estrutura profunda, alterações no âmbito da supervisão que modificam a estrutura de superfície poderão também servir para mediar a estrutura profunda e a estrutura de referência, para recuperar experiências e para alargar o leque de escolhas de modo a auxiliar as pessoas na modificação de suas próprias estruturas profundas.

Sobre esse processo, a educadora Luciana, em diferentes momentos de relato, deixou claro como the era agradável e desafiador pensar sua prática e suas crenças. Para a pesquisadora essa possibilidade de, em algumas circunstâncias, desencadear o processo reflexivo da educadora foi muito gratificante, até mais do que a própria transformação da ação, justamente por acreditar-se que uma mudança que possa ocorrer na ação, mas que não tenha tido sua real re-significação em termos de crenças e valores têm poucas chances de permanência.

Diz Oliveira-Formosinho (2007 p. 14) "Ser profissional reflexivo é fecundar, antes, durante e depois da ação, as práticas nas teorias e nos valores, interrogar para re-significar o já feito em nome da reflexão que constantemente o reinstitui."

Esse processo formativo será ilustrado neste trabalho por uma intervenção feita pela educadora no espaço reservado para a produção de artes visuais, que se encontrava disponível diariamente para utilização livre das crianças, no momento de atividades realizadas no espaço reorganizado.

Em 15/04/06, após o término do período de observação da pesquisadora, a educadora Luciana, em conversa informal, falou sobre uma observação que havia realizado, afirmando que com a disponibilidade diária de material para pintura as crianças demonstravam interesse e prazer em pintar, mas depois de um certo momento as atividades de pintura se transformavam sempre em "borrões".

O combinado foi então que a educadora observasse essa atividade mais detidamente nos dias posteriores e trocasse esses dados coletados com a pesquisadora.

A educadora relacionou os seguintes aspectos: a) as crianças demonstram prazer em pintar; b) cada criança faz várias pinturas; c) misturam as tintas dentro dos potes e os colegas ficam com cada vez menos opções de cores para seus trabalhos; d) preocupam-se mais com o processo que com o produto; e) há pouca figuração (formas definidas); e) limpam a mesa ao final da tarefa; f) gostam de pintar em grupo ou com os colegas mais próximos. 
Em 26/04/06 foi gravado um episódio de envolvimento, justamente quando a menina GAB-C realizava algumas pinturas.

Abaixo estão as fotos de alguns trabalhos realizados por ela e por outras crianças nesse dia.
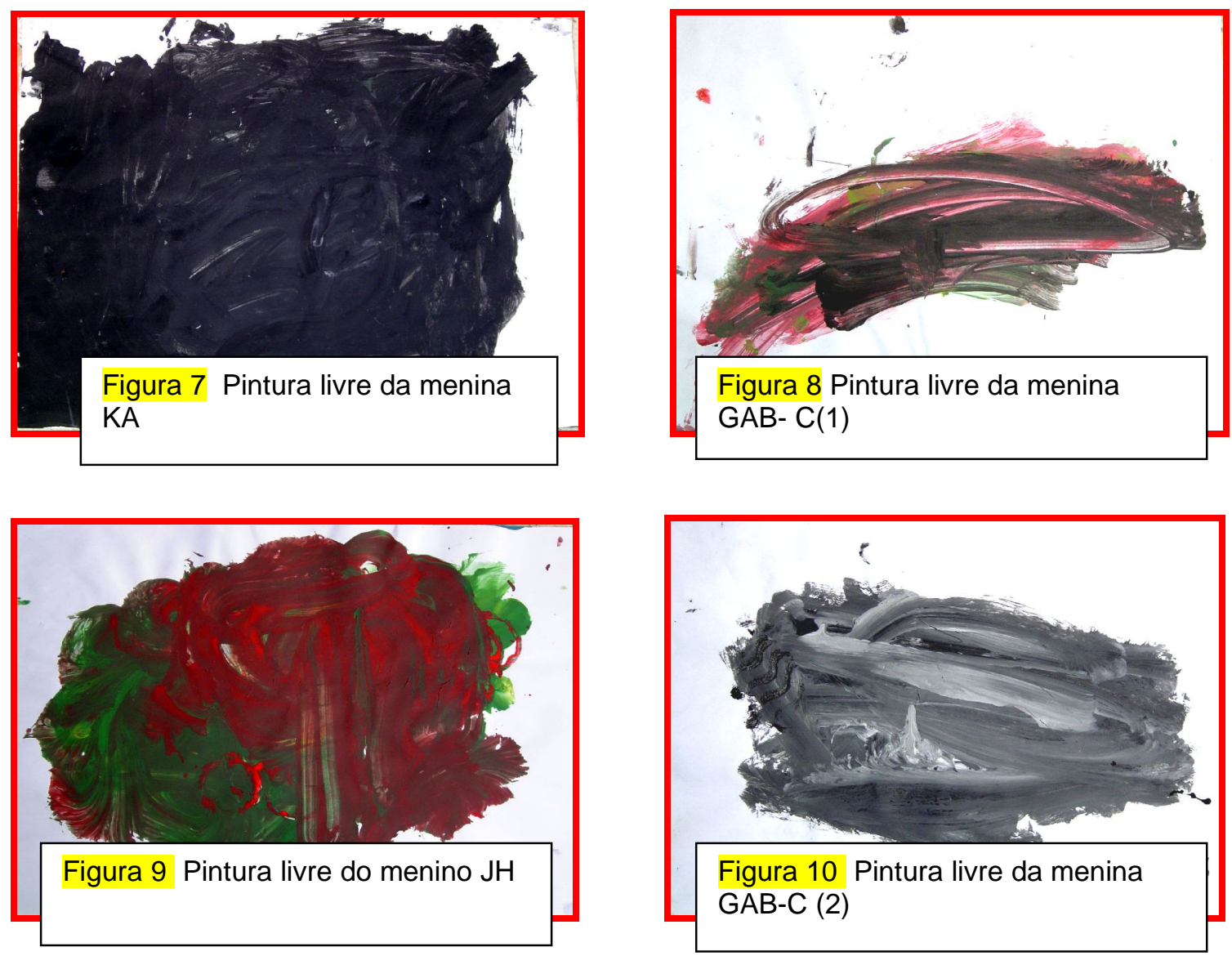

Na reunião de tutoria realizada em junho discutiu-se sobre o episódio gravado e as observações realizadas pela educadora e pela pesquisadora, quando foram analisadas as intervenções que já haviam sido realizadas após as observações iniciais da educadora, pensando os efeitos destas e planejando novas intervenções.

Entre outras ações a professora fez as seguintes intervenções:

Quadro 8 - Intervenções da educadora na atividade de pintura livre

\begin{tabular}{|l|l|}
\hline \multicolumn{1}{|c|}{ Tipo de intervenção } & \multicolumn{1}{|c|}{ Resultados obtidos } \\
\hline $\begin{array}{l}\text { Ensino de técnica que utiliza o cabo do pincel ou } \\
\text { outro objeto para produzir marcas sobre a tinta } \\
\text { (monotipia) }\end{array}$ & $\begin{array}{l}\text { Incorporação da técnica e utilização deste } \\
\text { recurso em outras produções espontâneas } \\
\text { (Figura 11 ) }\end{array}$ \\
\hline $\begin{array}{l}\text { Separação das tintas colocando um pincel em } \\
\text { cada pote e combinando com as crianças que } \\
\text { poderiam misturar as tintas à vontade no papel, } \\
\text { mas não dentro dos potes }\end{array}$ & $\begin{array}{l}\text { Uso da cor começou a ficar mais intencional } \\
\text { para muitas crianças (Figura 12 ) }\end{array}$ \\
\hline
\end{tabular}




\begin{tabular}{|c|c|}
\hline Tipo de intervenção & Resultados obtidos \\
\hline $\begin{array}{l}\text { Apreciação de obras de arte na roda de } \\
\text { conversa, buscando conhecer o processo de } \\
\text { produção do artista, perceber detalhes, discutir o } \\
\text { que está vendo, impressões e sensações que a } \\
\text { obra causou em cada um. }\end{array}$ & $\begin{array}{l}\text { Produções mais cuidadas, menor número de } \\
\text { pintura por crianças, mas com maior } \\
\text { envolvimento. Riqueza de detalhes nas } \\
\text { produções (Figuras } 13 \text { a 16 ) }\end{array}$ \\
\hline
\end{tabular}
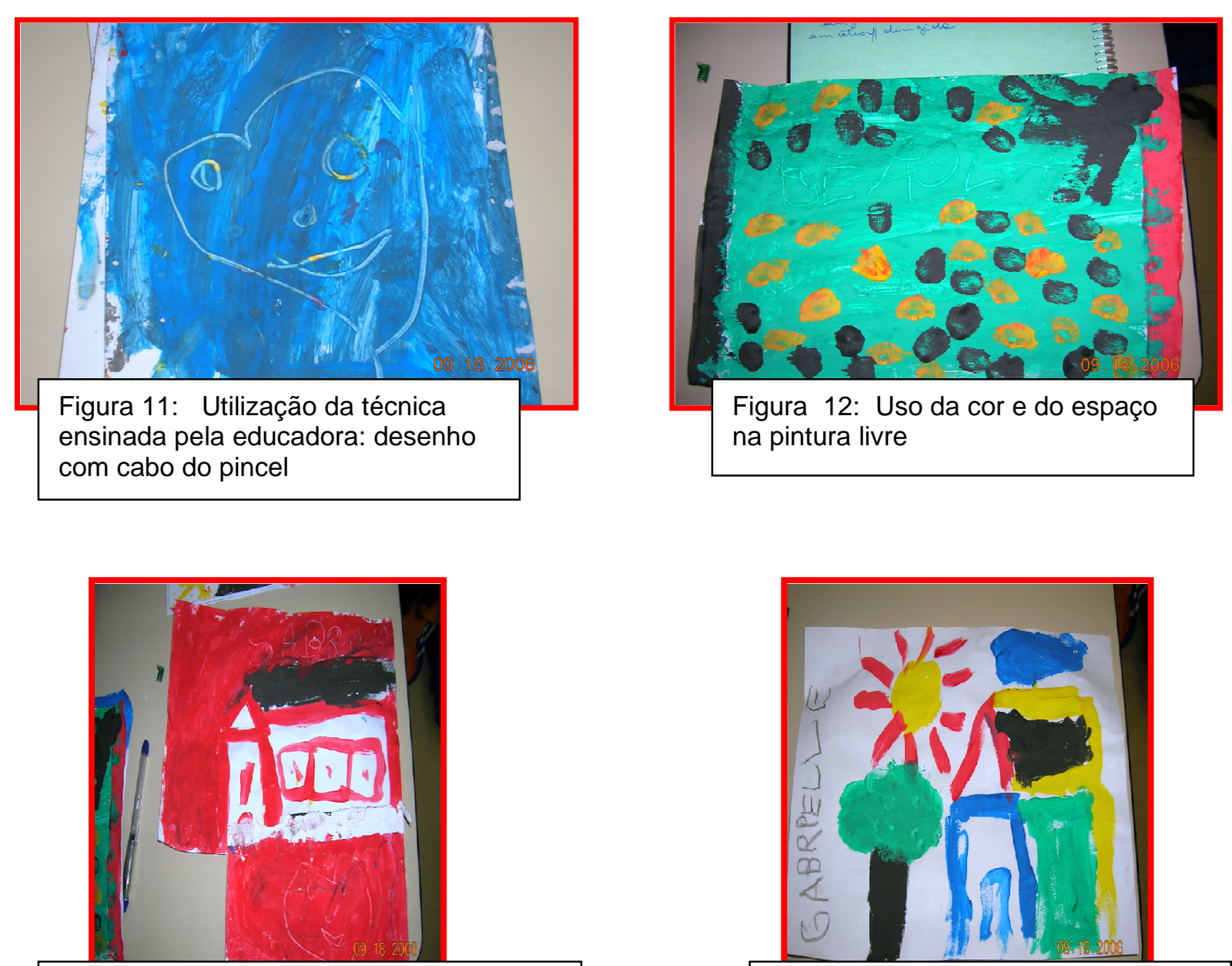

Figura 13: Pintura livres após observação de diferentes obras de arte

Figura 14: Pintura livre da menina GAB-C durante o processo

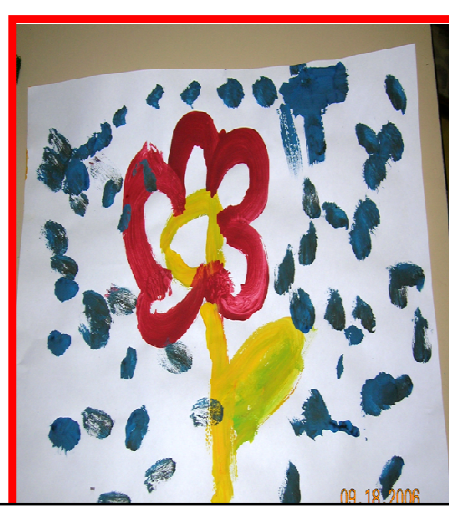

Figura 15: Pintura Livre: expressão individual mais cuidadosa

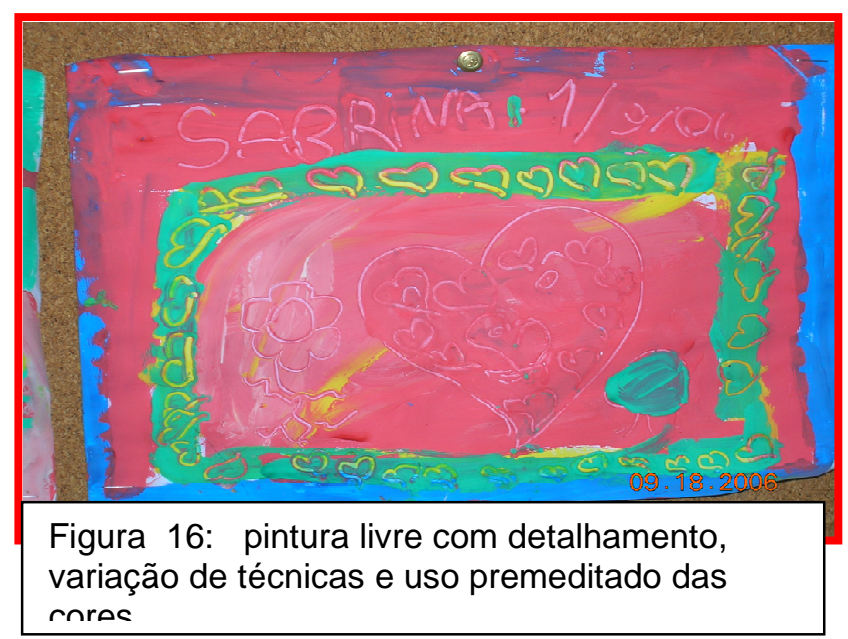


Como avaliação desse episódio do processo formativo desenvolvido na pesquisa através da tutoria identificou-se que: a) a educadora foi desenvolvendo um olhar mais sensível sobre as atividades das crianças, responsabilizando-se pela intermediação e pelo fornecimento de suportes para o processo de construção de conhecimentos delas; b) a educadora começou a atuar como pesquisadora, criando hipóteses para os problemas encontrados, planejando e atuando para interferir na realidade de maneira a modificá-la; c) a pesquisadora também modificou sua prática pedagógica influenciada pelo que viveu, observou e aprendeu com a educadora (parceria) e; d) a pesquisadora foi aprimorando sua capacidade de pesquisar à medida que, na interlocução com a professora, visualizava outros ângulos da situação analisada.

Atualmente, tem-se clareza de que as discussões ocorridas no momento de tutoria, envolvendo a produção artística das crianças, poderiam ter sido aprofundadas, agregando-se maior aporte teórico sobre o tema. Este aparente deslize, porém, traz em seu bojo a confirmação do processo de construção contínua da qualidade: da professora em relação a sua prática pedagógica e da pesquisadora em relação ao seu papel de investigadora e de organizadora do processo de tutoria.

Além das reuniões de tutoria, outro recurso utilizado no estudo empírico foi o auto-relato $^{36}$. Trata-se de um registro da educadora, reflexivo e pessoal, onde descreve de maneira espontânea e sem formalidade ou estilo pré-determinado experiências que teve na aplicação da proposta de Reorganização dos Espaços e das Atividades, observações sobre sua prática pedagógica, desenvolvimento dos alunos ou outros temas que julgasse relevantes.

Houve estímulo da pesquisadora para que este registro tivesse periodicidade quinzenal, mas ele variou de acordo com a disponibilidade da educadora.

$O$ auto-relato consta em geral de observações curtas, diretas e francas que apesar de algumas vezes conterem poucos dados, dão à pesquisadora alguns parâmetros para compreensão do viés de interpretação que a educadora foi atribuindo aos acontecimentos de sua prática em sala de aula e de seus efeitos sobre as crianças.

\footnotetext{
${ }^{36} \mathrm{O}$ anexo $\mathrm{E}$ traz alguns excertos de auto-relatos da educadora.
} 
O processo reflexivo é um meio de aprimorar o olhar e a capacidade de avaliação sobre as práticas pedagógicas executadas. Afirma Bogdan (1994, p. 55):

[...] o significado que as pessoas atribuem às suas experiências, bem como o processo de interpretação, são elementos essenciais e constitutivos, não acidentais ou secundários, àquilo que é a experiência. Para compreender o comportamento é necessário compreender as definições e o processo que está subjacente à construção destas.

No total a educadora fez, em 2006, 15 auto-relatos sobre sua prática pedagógica. Os principais temas dos auto-relatos foram:

Quadro 9: Cronograma de auto-relatos da educadora

\begin{tabular}{|c|c|}
\hline Data & Tema \\
\hline $12 / 02$ & $\begin{array}{l}\text { Proposta de Reorganização dos Espaços e das Atividades, diferentes } \\
\text { tempos das crianças para sua realização }\end{array}$ \\
\hline $13 / 02$ & Autonomia das crianças \\
\hline $17 / 02$ & Uso do computador \\
\hline $03 / 03$ & Autonomia das crianças para realizar a mesma atividade várias vezes \\
\hline $07 / 03$ & Organização dos materiais, dificuldades \\
\hline $13 / 03$ & Idem \\
\hline $15 / 03$ & $\begin{array}{l}\text { Formas de agrupar as crianças para realização das atividades } \\
\text { orientadas }\end{array}$ \\
\hline Maio & Mudanças dos brinquedos e organização das crianças \\
\hline $\begin{array}{c}\text { Junho } \\
1^{\text {a }} \text { quinzena }\end{array}$ & $\begin{array}{l}\text { Modificação do processo de orientação da educadora para realização } \\
\text { das atividades orientadas }\end{array}$ \\
\hline $\begin{array}{l}\text { Junho } \\
2^{\mathrm{a}} \text { quinzena }\end{array}$ & Barulho da sala e intervenções realizadas pela educadora \\
\hline Julho & $\begin{array}{l}\text { Hora da atividade orientada? Organização das crianças e respeito a } \\
\text { suas necessidades }\end{array}$ \\
\hline Data & Tema \\
\hline Agosto & $\begin{array}{l}\text { Observações da pesquisadora e possibilidades de intervenção da } \\
\text { educadora }\end{array}$ \\
\hline 4,5 e $6 / 09$ & Influência do ambiente sonoro da classe na realização das tarefas \\
\hline 11 a $15 / 09$ & Foco de observação da educadora: brincadeira das crianças \\
\hline 18 a 22/9 & $\begin{array}{l}\text { Necessidade de intervenções da educadora para organizar as atividades } \\
\text { em grande grupo }\end{array}$ \\
\hline
\end{tabular}


Vale ressaltar que além desses relatos, em conversas informais com a pesquisadora após o acompanhamento da prática pedagógica, geralmente a educadora Luciana fazia observações sobre 0 ocorrido e os possíveis desdobramentos advindos daquelas ações para as práticas futuras junto às crianças.

\subsubsection{O processo de tutoria e seus efeitos}

Por ocasião da discussão sobre a proposta pedagógica da unidade educacional onde a pesquisa aconteceu ${ }^{37}$ já se pôde esclarecer sobre a existência de espaços reorganizados, em que a autonomia da criança era expressa através da manifestação das necessidades e interesses das crianças, bem como do seu protagonismo nas ações. O espaço que a educadora encontrou em 2006, decorrente do processo anterior de reorganização, tinha uma área com quatro mesas, o canto do computador, a área de brincadeira próxima à lousa e às janelas, bem como uma área livre central. A mesa da educadora passou a ser suporte de alguns brinquedos e os demais foram divididos por tipos de materiais e acondicionados em baldes e caixas plásticas, conforme mostram as fotos (figuras $2,3,17,18,19,20)^{38}$ abaixo:
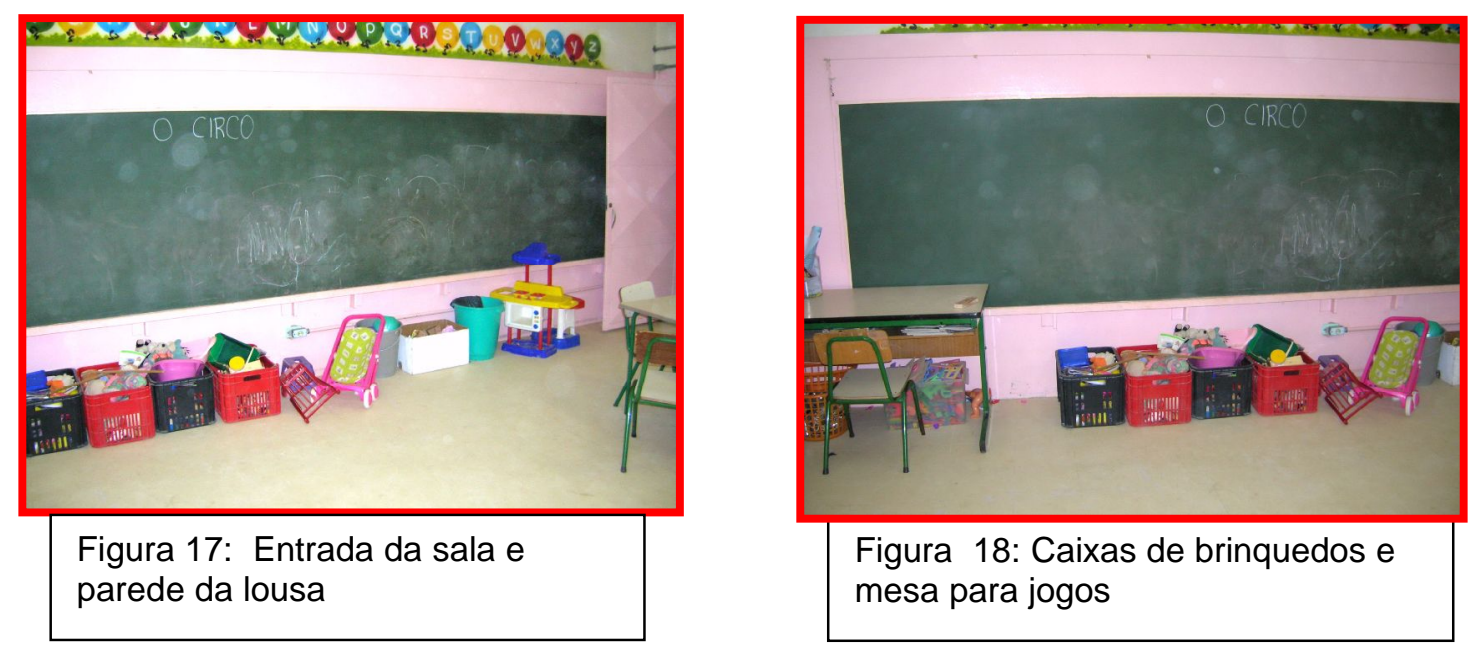

\footnotetext{
${ }^{37}$ A proposta pedagógica adotada pela EMEl encontra-se explicitada no capítulo 1 e as informações sobre a unidade educacional estão detalhadas no item contexto da investigação (capítulo 4.)

${ }^{38}$ as figuras 2 e 3 já foram apresentadas no capítulo 1 para ilustrar a proposta pedagógica de Reorganização dos Espaços e das Atividades
} 

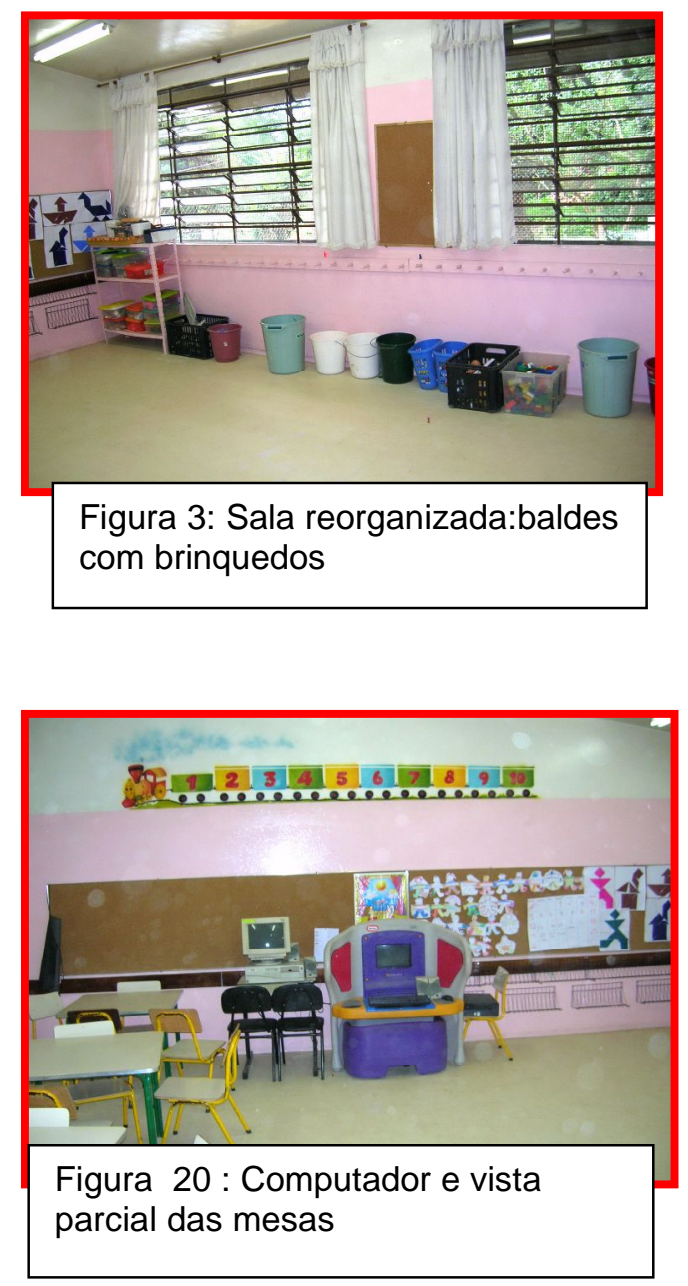

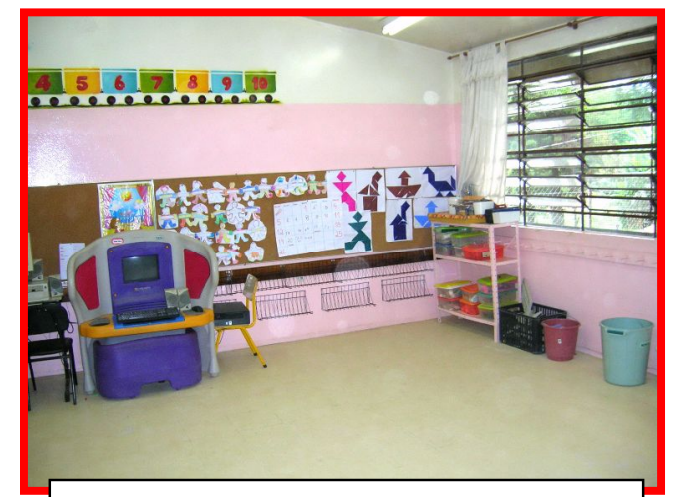

Figura 19: Painel de cortiça e computador de uso das crianças

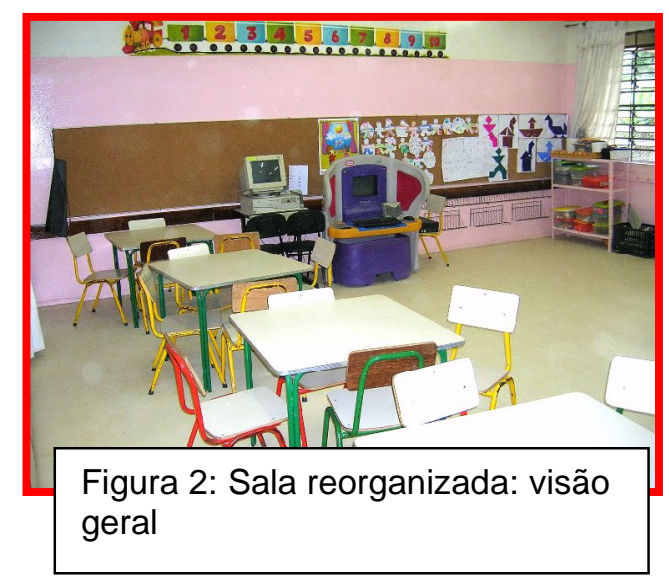

Houve uma alteração neste espaço feita pela educadora com apoio da administração da unidade educacional e do grupo de professores que teve como objetivos tornar os cantos mais atrativos, com maior riqueza e diversidade de material (que pudessem dar suporte mais adequado à brincadeira).

No final de maio de 2006, a sala já tinha a seguinte configuração:
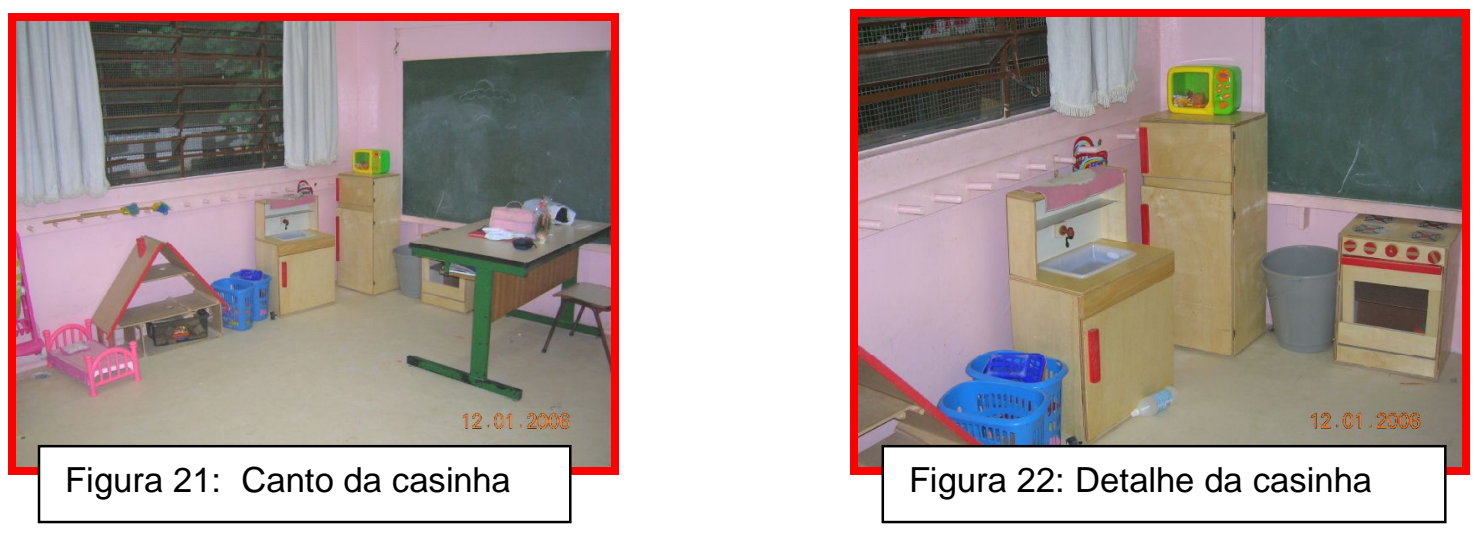

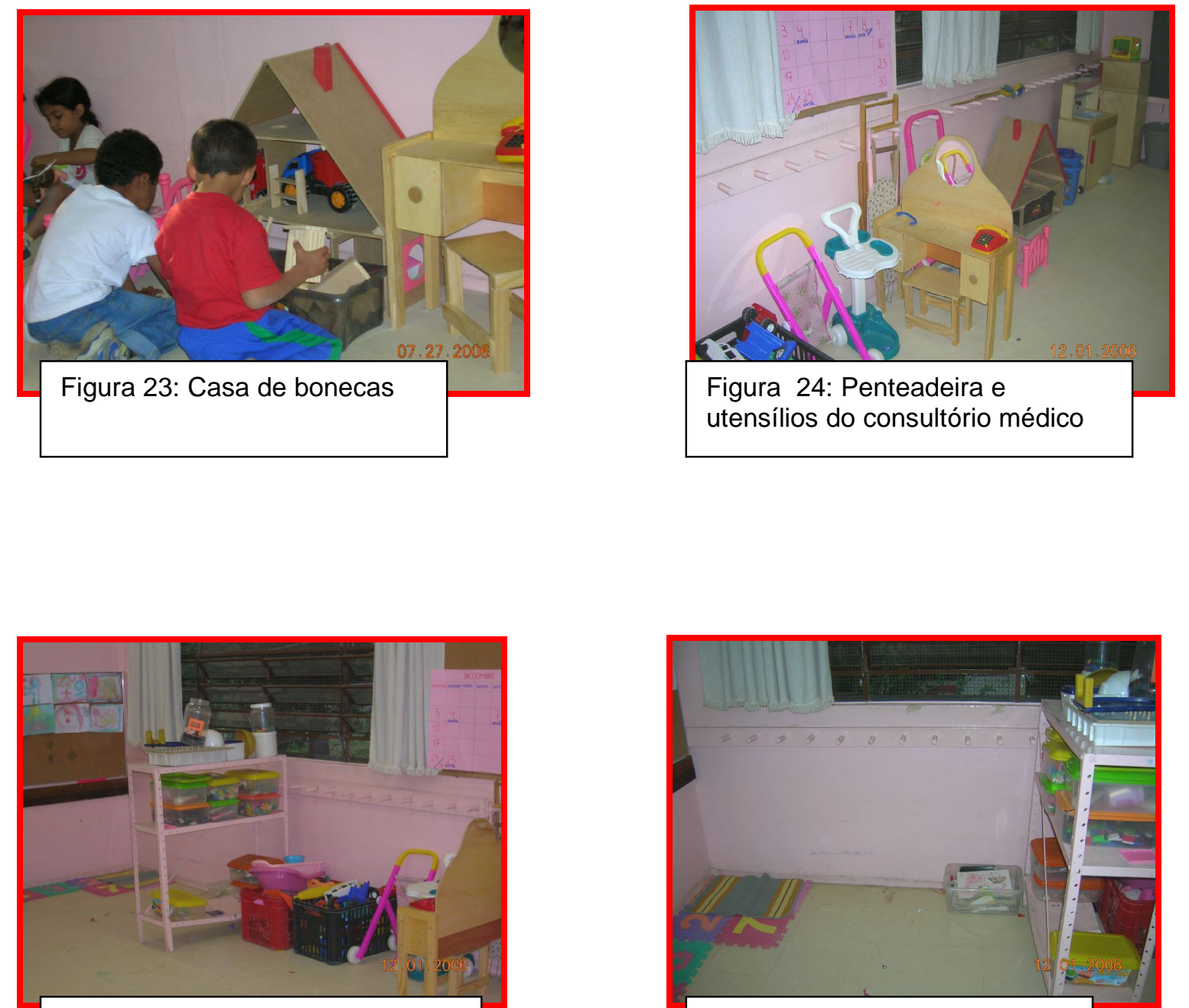

Figura 25: Prateleira com jogos e caixa de carrinhos
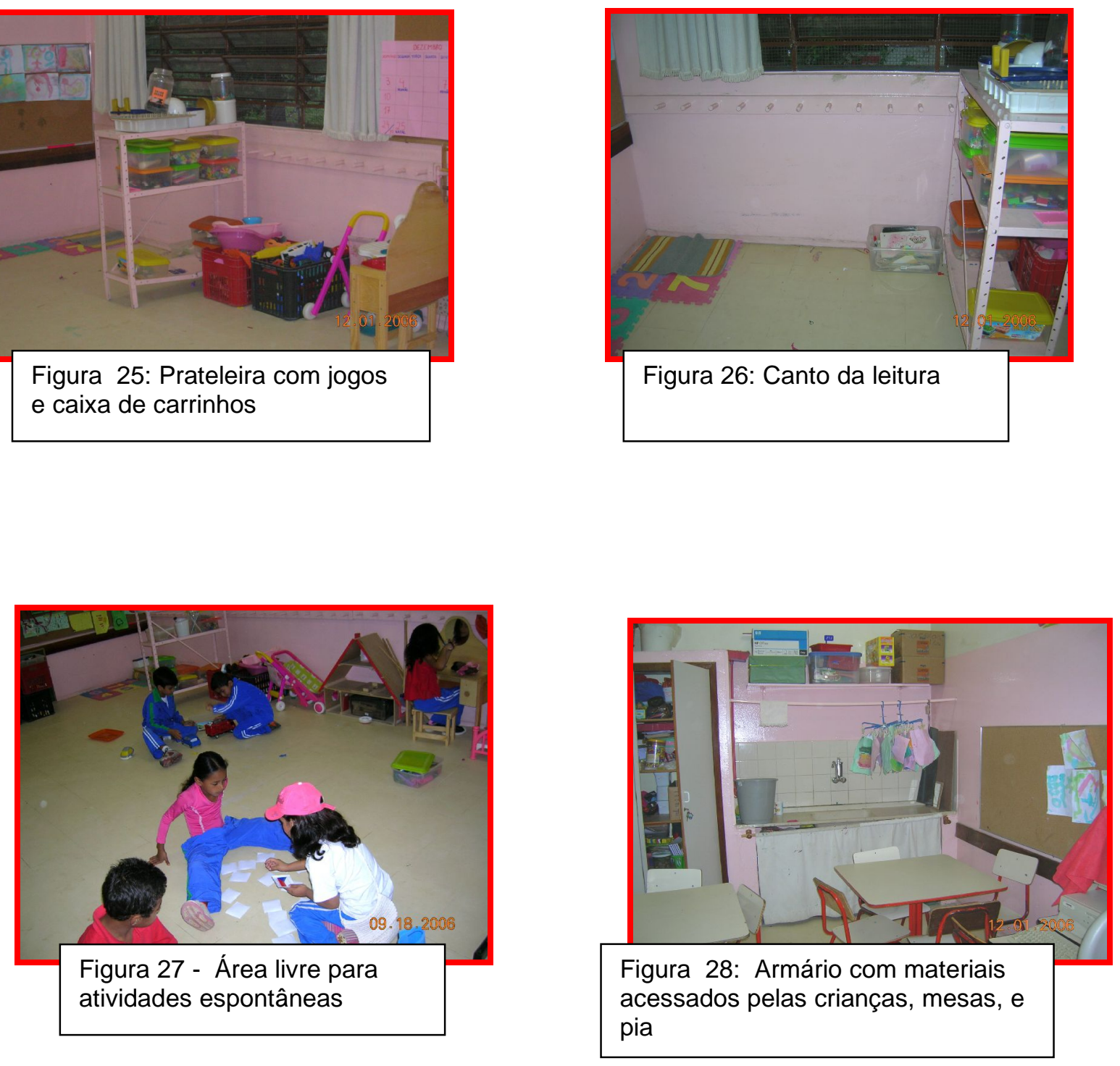

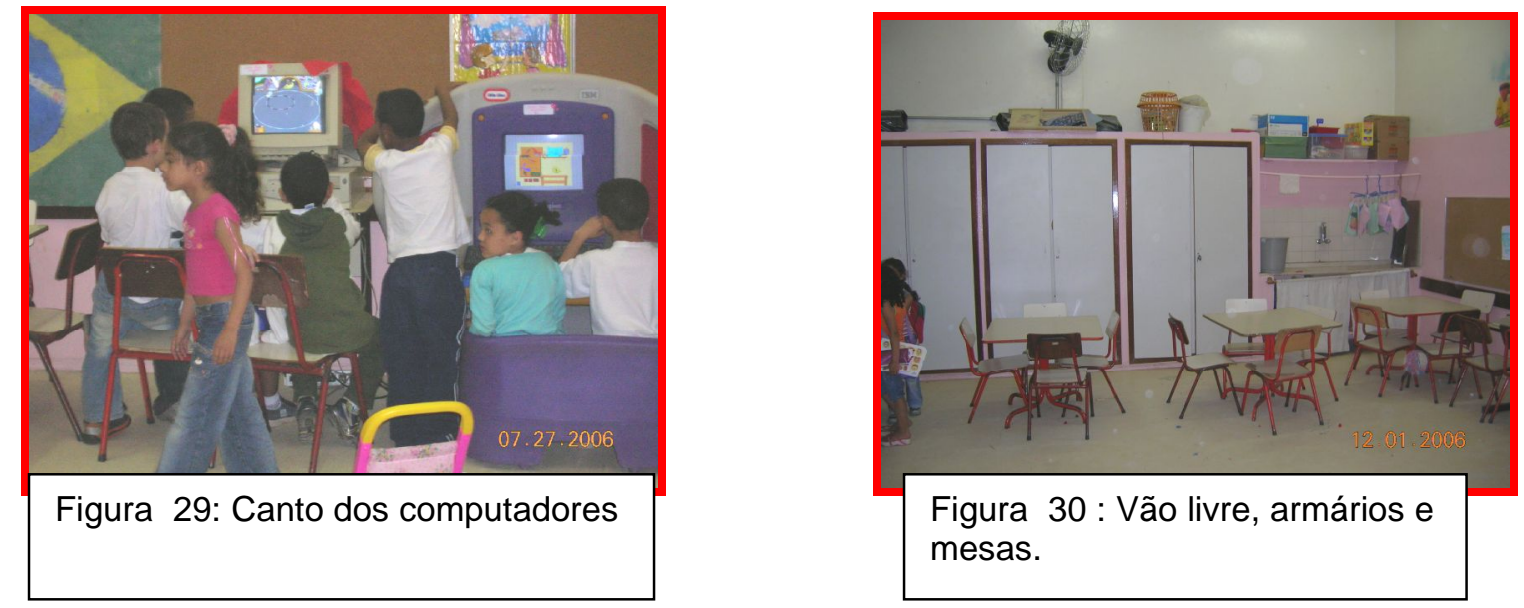

Avaliou-se que a reflexão sobre a ação gerou, na prática dessa educadora, alterações relacionadas à organização do espaço, aos materiais disponíveis, às atividades orientadas propostas. Entendemos, todavia, que estruturando todas estas práticas de transformação havia uma alteração real em seu sistema de crenças, do que é ser educador, do que é prioridade no processo ensino-aprendizagem e da forma como a criança constrói conhecimento dentro do seu contexto.

Mesmo que estas "novas" crenças não tenham ficado explícitas, todo o tempo estão subjacentes na fala e na ação da educadora. Um exemplo disso está relacionado com suas idéias sobre os materiais (brinquedos e outros) que existiam no espaço da sala reorganizada.

No início do ano a educadora, em entrevista concedida a pesquisadora, afirmou que, olhando o material disponível para o manuseio, acreditava que as crianças teriam grandes dificuldades. Dizia ela: "a princípio, pela quantidade de brinquedos eu fiquei pensando assim: se a criança tiver todos esses brinquedos disponíveis ela até se perde um pouco, né? Eu pensei em apresentar aos poucos esses brinquedos" (Entrevista com a educadora Luciana, realizada em março de 2006).

Observou-se, contudo, que com o passar do tempo a educadora não só manteve a diversidade e quantidade de materiais disponíveis, como foi introduzindo novos, trouxe de seu acervo pessoal um quebra-cabeças, oportunizou o uso de materiais mais variados para as produções artísticas das crianças, criou jogos cooperativos, trouxe massinha caseira etc. 

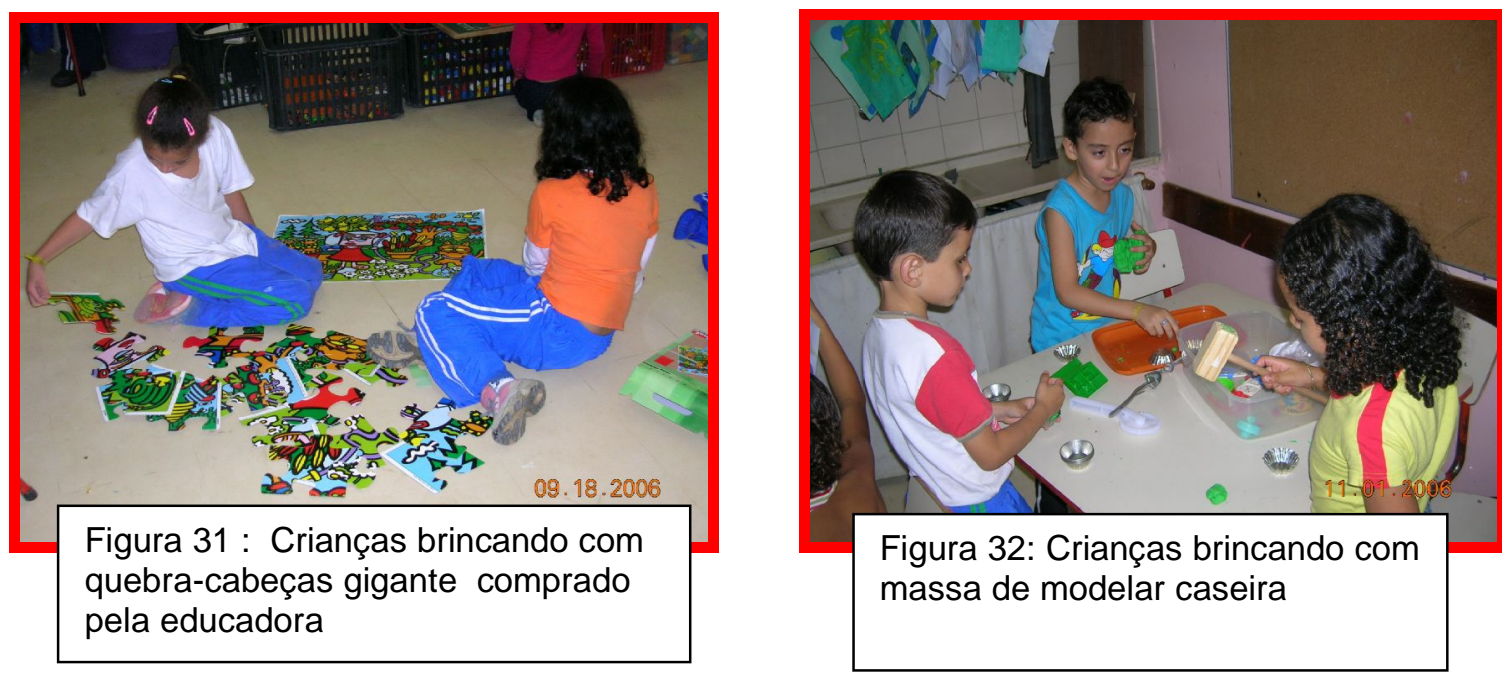

Figura 32: Crianças brincando com massa de modelar caseira
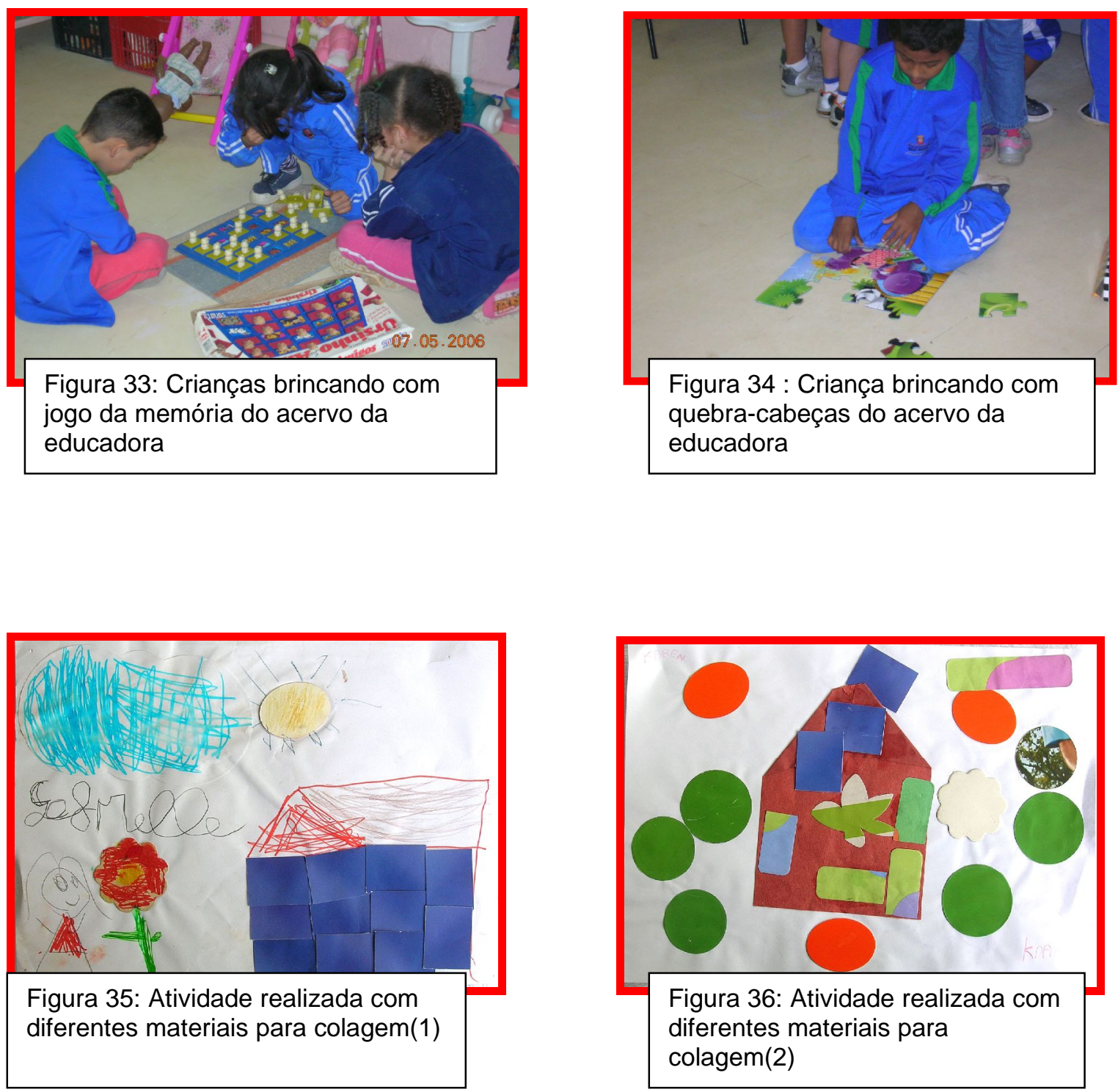

Figura 35: Atividade realizada com diferentes materiais para colagem(1) diferentes materiais para 

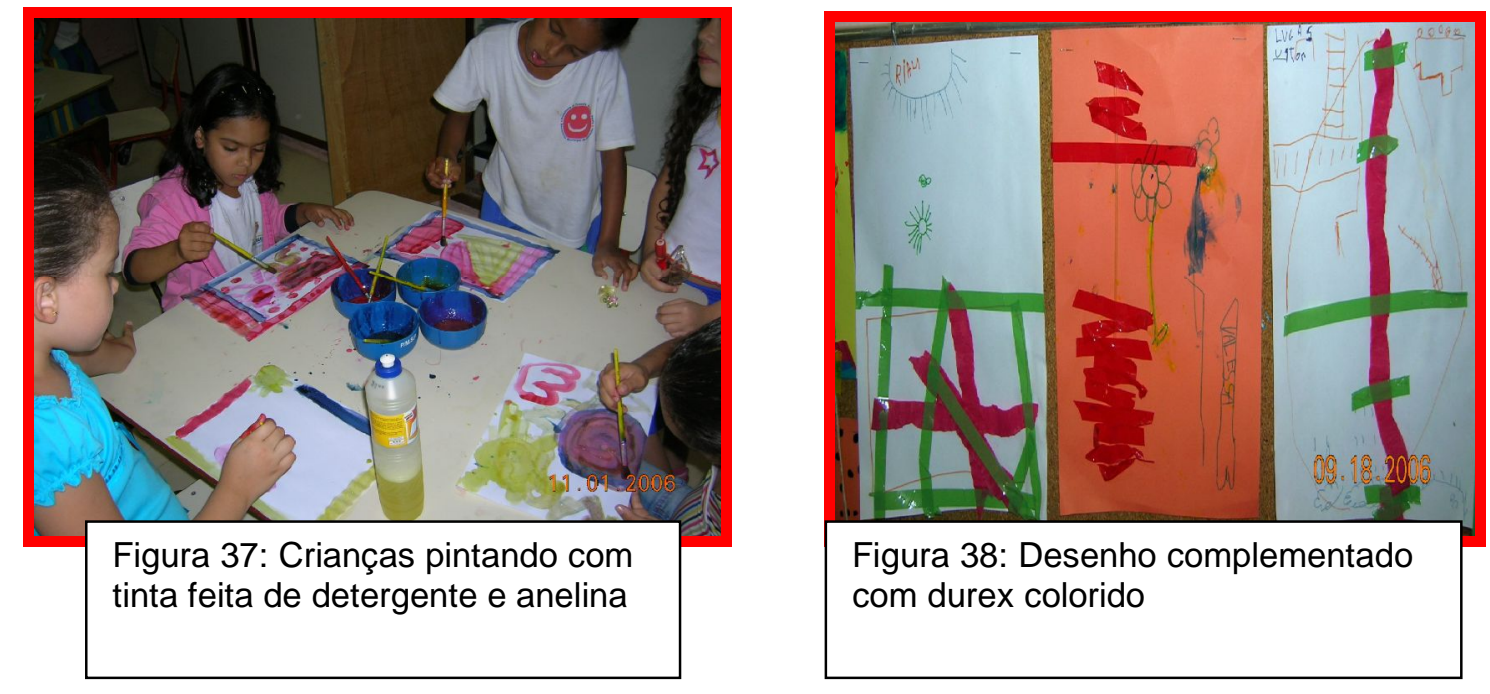

Sobre o tema da diversidade e quantidade de materiais oferecidos à criança, a educadora comenta em dezembro:

Eu lembro que no começo do ano, acho que na primeira vez que a gente conversou, que a gente estava lá na sala e eu fiquei assim admirada com a quantidade de materiais que havia na sala. Eu achava que eles nem iam conseguir se organizar com aquilo, hoje eu acho assim que tem pouco, que poderia ter bem mais" (Entrevista de dezembro de 2006).

Reflete ainda sobre sua prática e sobre as concepções que tinha referentes à capacidade das crianças, dizendo:

Eu acho que eu menosprezava um pouco essa capacidade deles até de conseguir se organizar, de conseguir, sei lá... mesmo assim de trabalhar num ambiente que tem tantas possibilidades, escolher... Eu achava assim: é tanta coisa [...] se um vai fazer uma coisa e o outro vai fazer outra coisa completamente diferente, será que vai dar pra se organizar? [..] então acho que isso era uma coisa que eu achava que eles não iam conseguir e eles conseguem muito bem (Entrevista de dezembro de 2006).

Os aspectos abordados na tutoria tinham o objetivo de levar os envolvidos à reflexão sobre o papel do educador nesta proposta pedagógica, suas possibilidades e dificuldades e os impactos nas crianças. 
Essa posição de professor pesquisador que olha sua prática de maneira questionadora, com um estranhamento que leva à analise de diferentes ângulos da situação era todo o tempo estimulada e a educadora incorporou essa postura em sua prática. Um exemplo disso foram as alterações que ela foi, paulatinamente, estabelecendo no seu papel de mediador do processo de construção de conhecimentos das crianças.

As atividades orientadas, propostas pela educadora para realização de todas as crianças da sala, sofreram também alterações significativas. Inicialmente, apesar de haver um cuidadoso planejamento feito pela educadora, as atividades ainda tinham cunho preparatório ou escolarizante, como as que coletamos entre fevereiro e março:
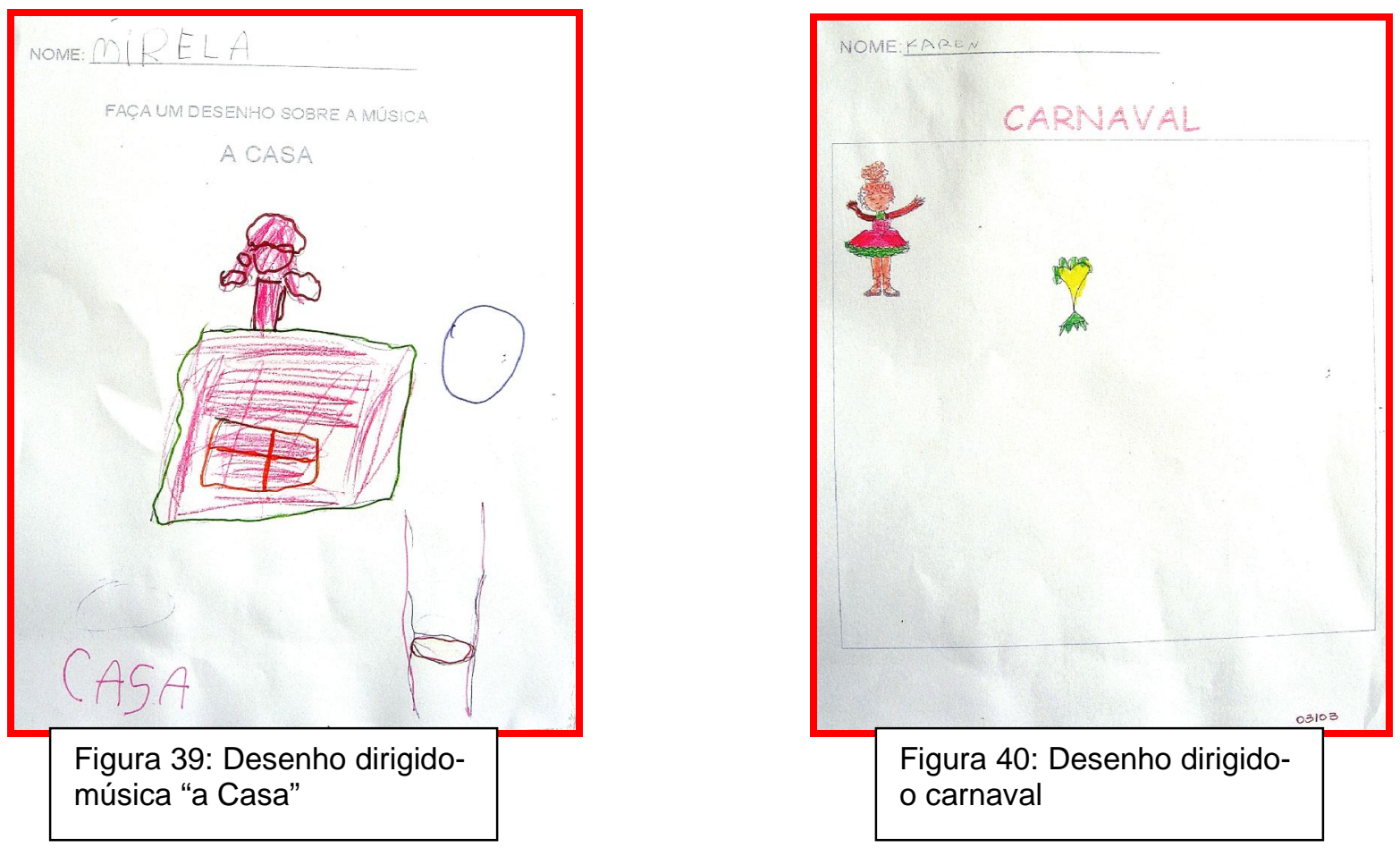

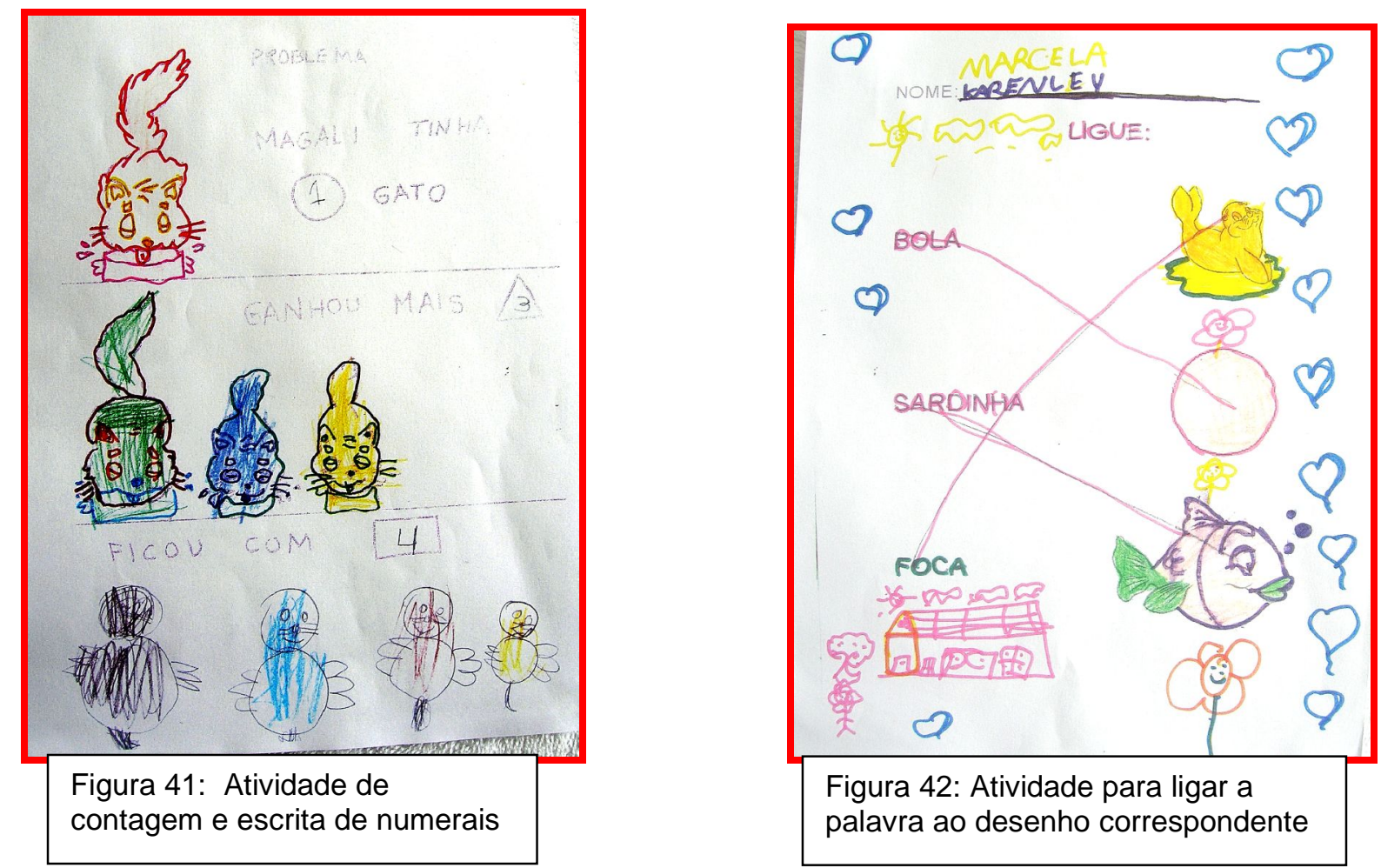

Nota-se que com o passar do tempo as atividades foram se complexificando e, ao mesmo tempo em que se tornavam mais desafiadoras, a educadora buscava pouco a pouco maneiras de oferecer à criança o protagonismo da ação, possibilitando e valorizando suas escolhas e seu desempenho.

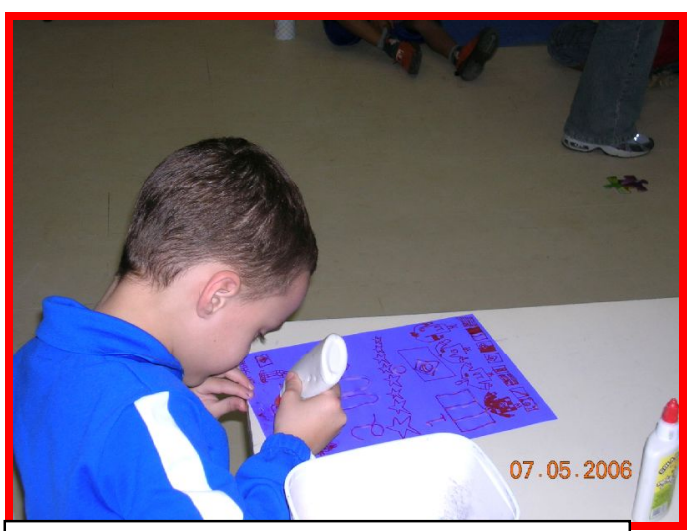

Figura 43: Menino desenha com cola sobre desenho feito com canetinha

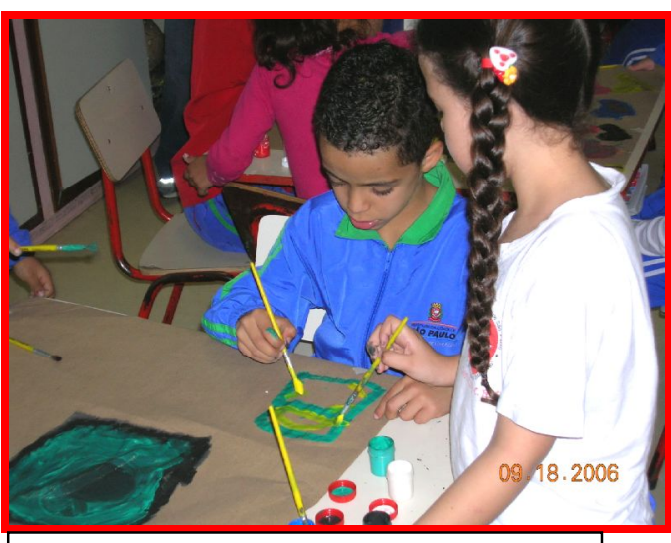

Figura 44: Pintura em grupo 

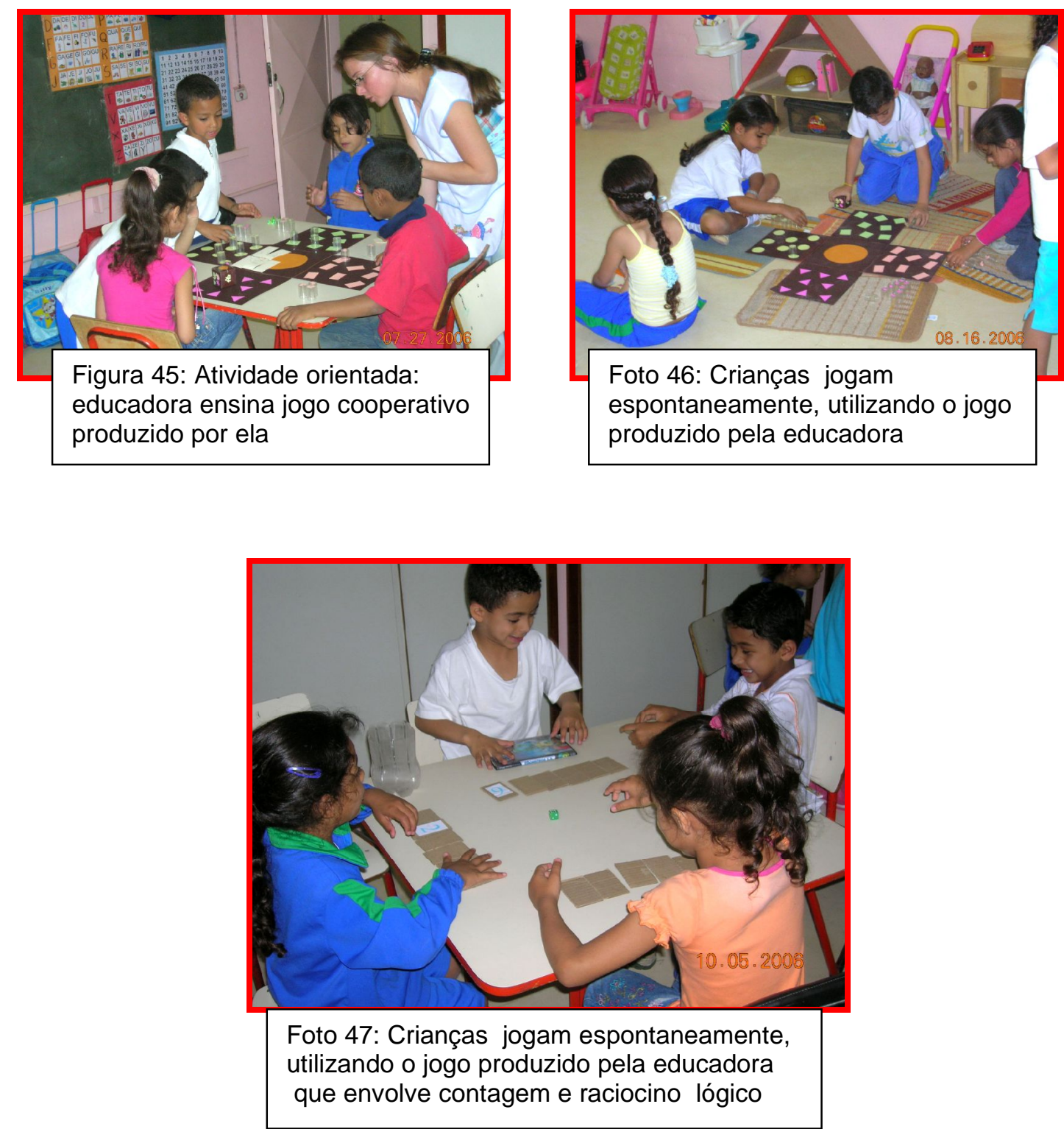

As falas da educadora refletem essas alterações e o efeito que elas foram efetuando em suas crenças sobre seu papel de mediadora. Diz ela:

[...] Fiquei surpresa. Hoje uma das atividades propostas foi pintura e quando pedi que reorganizassem o espaço eu fui auxiliá-los na reorganização da brincadeira, mas quando retornei para a mesa de pintura ela também já estava arrumada. Haviam jogado os potes vazios de tinta no lixo, lavado e colocado no lugar os pincéis e também guardado os potes com um pouquinho de tinta. Enfim, eles me surpreenderam. Acho que muitas vezes não permitia que me mostrassem do que eram capazes (auto-relato 13 de fevereiro 06)

[...] Estava chovendo.... sugeri que fizéssemos pintura e hoje todos quiseram fazer a mesma atividade. Nunca tinha permitido que uma criança fizesse várias pinturas como hoje. auto-relato 13/3/06). 
[...] Algumas crianças utilizaram apenas uma folha enquanto outras quatro, cinco folhas. Foi bem legal observar o interesse e envolvimento deles e permitir que pintassem quantos quisessem, sem muitas restrições como eu me via obrigada a fazer antes, por uma questão de "ordem", tempo. (autorelato $13 / 3 / 06)$.

Este processo reflexivo é um caminho em construção, com avanços progressivos, mas também com tropeços. Notou-se, na coleta de dados, que a educadora ainda demonstrava em vários momentos dificuldade para re-significar completamente seu papel de educadora frente a uma criança ativa e centro do processo educativo, bem como de priorizar a auto-iniciativa da criança em contrapartida ao cumprimento de tarefas "ideais" propostas pela educadora. Diz ela:

O fato de poder acompanhar aquele grupo que está fazendo atividade é o que eu acho de mais gostoso. Chamar a criança que tem muita dificuldade, (não muita) e você poder acompanhar e ver (o sucesso ${ }^{39}$ ) é muito gostoso também. Tinha crianças que eu só ia ver o resultado, agora não, você senta, você ajuda, é muito gostoso (Entrevista de outubro de 2006).

[...] Eu sinto muitas dificuldades ainda, essa coisa de como interferir, de como ajudá-los em alguns momentos (entrevista de outubro de 2006).

[...] Às vezes eu ainda presto bem mais atenção nas crianças que estão fazendo atividade. Hoje eu ainda consigo (acho) dar uma olhadinha, sair um pouco da atividade em si, mas eu ainda não consegui tirar o foco (Entrevista em outubro de 2006),

Apesar destas considerações, observando a educadora em suas atividades e seus relatos, acredita-se que houve um aprimoramento do seu olhar, resultado que vinculamos ao processo reflexivo que se voltou à análise da prática pedagógica.

Esse olhar mais detalhado sobre a realidade que se apresentava levou-a à criação de novas questões e a um maior número de observáveis que passaram a servir de base para seu processo de mediação junto às crianças. Conforme o autorelato do período de 11 a 15 de setembro:

[...] durante esta semana tentei observar as brincadeiras, coisas que faço pouco, pois a maior parte do tempo está voltado para as atividades propriamente ditas. Observei que é comum algumas crianças procurarem a mesma atividade em diferentes dias, que especialmente a brincadeira de casinha é procurada tanto por meninas quanto por meninos, que durante a brincadeira surgem colocações bastante adequadas como, por exemplo,

\footnotetext{
${ }^{39}$ Pelo teor do relato infere-se que a educadora fez referência ao sucesso.
} 
receitar banho frio sempre que a febre subir; que muitas vezes por uma questão do espaço a brincadeira acaba sendo prejudicada; que regras sempre acabam aparecendo, não apenas nos jogos mas também nas brincadeiras e principalmente que por não acompanhar as brincadeiras de perto muitas vezes minhas interferências são inadequadas, como por exemplo: é comum interferir quando misturam brinquedos, quando na verdade estão querendo fazer em outro espaço uma outra cozinha ou quando um segura, aperta o colega mas na brincadeira aquilo faz sentido, é por exemplo a injeção (auto-relato referente ao período acima).

Como efeitos do processo reflexivo, estimulado pela pesquisa-ação e particularmente pela tutoria entre os pares, consideramos que a educadora Luciana tornou-se cada vez mais atenta às ações das crianças, aprimorando a observação e a escuta delas e fazendo uso destes dados coletados, de maneira a incorporá-los às suas decisões para realizar alterações na sua prática pedagógica.

As ações da educadora passaram a servir como desafios e suportes mais adequados às crianças. Sua capacidade de adaptar o "planejado" aos interesses demonstrados pelo grupo ficou clara em diferentes momentos da observação.

Nas notas de campo da pesquisadora (31/10/06) vê-se que a educadora notou haver grande interesse das crianças, durante a brincadeira espontânea na hora do trabalho reorganizado, pela capa de tecido que imitava a capa utilizada pelo "super homem" nos filmes e quadrinhos, que tinha sido trazida por um dos alunos. A educadora, detectando o interesse de muitas crianças, perguntou o tipo de material que precisavam para confeccionar suas capas e disponibilizou este material para os que desejassem fazer suas capas, ficando apenas como agente de apoio quando solicitada. Permitiu também que todas as ações tivessem o protagonismo e fossem negociadas entre as crianças as parcerias necessárias para as tarefas que envolviam medição, recorte, colagem, amarração do barbante, entre outras.

Após o término da observação, a pesquisadora pediu à educadora Luciana que ela avaliasse a confecção das capas pelas crianças. Ela afirmou que percebeu claramente aspectos de autonomia e parceria entre as crianças, para corte do papel, amarração do barbante etc. e que o principal aspecto para ela tinha sido o grande envolvimento e prazer demonstrados pelas crianças na atividade que desempenharam.

Analisando sua prática na proposta pedagógica que privilegia a ação da criança, e pensando a questão do bem-estar, a educadora Luciana enfatiza: 
Para eles é sem dúvida mais prazeroso. Eu não tenho criança que não gosta de vir para a escola, que não gosta de estar com os amigos, de brincar com os amigos e antes eu conseguia perceber algumas crianças assim. Quando vem de outra sala também ${ }^{40}$ que você ouve os comentários; é bem legal, eles gostam bastante.

[...] A mãe de uma aluna minha falou que ela nunca nem perguntou da outra sala depois que ela mudou... ela mudou da classe em julho/agosto, vindo do período da manhã. Eu perguntei se ela tinha saudades dos amigos da manhã e ela: - "Não, não... aqui tá bom, aqui tá tudo bem" (entrevista outubro 2006).

As observações demonstraram que esta perspectiva de bem-estar das crianças estava muito presente nestes momentos de trabalho reorganizado. Creditase isso ao clima que era estabelecido de aceitação da necessidade e dos desejos das crianças, respeitando seu protagonismo e possibilitando a realização de diferentes ações através das atividades de livre-escolha.

Em diferentes momentos a educadora Luciana também aponta isso como ponto positivo, enfatizando, porém, que aprender a lidar com a autonomia da criança é um grande desafio:

Lidar com essa liberdade, com essa autonomia que eles têm às vezes é difícil. Às vezes eles não aceitam muito, não. Também, eles ficam: "- Mas por que não pode hoje?" "- Por que não pode tinta?" Eles questionam mais, às vezes lidar com isso é tudo muito novo, é diferente (Entrevista realizada em outubro de 2006).

Esta autonomia progressiva da criança foi uma alteração visível na prática pedagógica acompanhada pela pesquisa. Ela ficava explícita no tipo de propostas de atividades orientadas que a educadora fazia, na sua preocupação com a garantia de possibilitar às crianças diferentes opções de materiais e de ações, na sua disponibilidade para ouvir as reivindicações e argumentos das crianças, entre outras situações.

Para Kiskimoto (2002, p. 184) "a autonomia só é possível quando se garante a cidadania à criança, com suporte ambiental e atividades para que as escolhas possam ocorrer".

Oliveira-Formosinho (2006, p. 27) enfatiza:

[...] no âmbito de uma pedagogia da infância transformativa preconiza-se a instituição de um cotidiano educativo que conceitualiza a criança como uma pessoa com agência [...] faz parte do conceito de agência que a pessoa

\footnotetext{
${ }^{40} \mathrm{Na}$ falta de alguma educadora, por vezes as demais dividem as crianças presentes, ficando com algumas crianças que são de outro agrupamento.
} 
possa escolher cursos diversos para sua ação, logo, tenha liberdade. $O$ poder de escolha real requer o direito da liberdade.

Percebe-se, portanto, acompanhando a ação da educadora, profundas transformações de sua prática pedagógica, consideradas atreladas às mudanças de concepções sobre o papel do educador e sobre o processo de construção de conhecimentos da criança pequena. Essas mudanças de concepção também podem ser notadas quando, em dezembro de 2006, a educadora Luciana vai falar sobre sua prática, buscando estabelecer relações com suas ações em anos anteriores, com classes de contextos muito próximos a esta. Diz ela:

[...] Eu acho que é diferente assim, me angustiava muito aquela questão de todo mundo fazer a mesma coisa na mesma hora, na quantidade que eu queria, era realmente uma pré-escola, estava preparando realmente pra primeira série mesmo e crianças muito pequenas, parece que não cabiam eles ali. Se eu tivesse que voltar, ia ser diferente, pelo menos eu ia tenta fazer diferente. Mas eu não consigo nomear o quê, exatamente (Entrevista dezembro 2006).

Nota-se que o peso dado à escolarização aponta ter apresentado profundas alterações, o próprio fato de falar "parece que não cabia" crianças pequenas ali já demonstra essas mudanças.

Em outro comentário, quando compara o "rendimento" ou a aprendizagem das crianças na prática acompanhada em 2006, em relação à dos anos anteriores, afirma que, contrariando as suas hipóteses iniciais de que com essa proposta pedagógica as crianças aprenderiam uma quantidade menor de conteúdos esperados, mesmo sem o cunho escolarizante as crianças fizeram significativos ganhos na sua aprendizagem. Diz Luciana:

[...] E às vezes a gente esquece mesmo os objetivos da educação infantil, a gente fica tão preocupada com algumas questões e o fato deles terem tanta autonomia, deles experimentarem tantas coisas diferentes, isso pra gente pelo menos é o mais importante.

[...] Não sei como seria essa proposta no ensino fundamental, mas aqui na educação infantil pra gente é o caminho, é uma possibilidade muito boa... (Entrevista em dezembro de 2006).

A educadora Luciana analisa que ações realizadas junto à criança, respeitando seu protagonismo, é um meio possível para se atingir os objetivos propostos. Por exemplo, quanto à questão relacionado ao autocontrole, em 
entrevista de dezembro de 2006 afirma: "acho que eles aprenderam de outra forma como se controlar, porque se eu tivesse mesas e cadeiras na sala de aula eles iam ter que aprender isso meio que forçados. Eles iam ter que ser forçados a isso".

Essa reflexão sugere significativas alterações na prática pedagógica implementada, mudanças estas que se apresentam nos objetivos que se elencam para a educação infantil: baseados numa concepção de criança enquanto sujeito cognoscente, ativo, produtor de culturas, capaz de estabelecer significações para o vivido e expressar-se num mundo de relações.

Nota-se, também, que ao realizar a avaliação dos trabalhos no fim do ano letivo, a educadora Luciana já demonstrava um olhar mais refinado sobre as aprendizagens que a criança fazia pela ação. Ainda na entrevista de dezembro de 2006, ressalta:

O fato de eles terem oportunidade de decidirem pelo que querem fazer naquele determinado momento também foi bastante favorecedor....

[...] Às vezes eu propunha alguma coisa em sala de aula, eles faziam aquela atividade naquele dia e nunca mais tinham oportunidade de experimentar aquilo, de explorar, aprofundar mais aquilo. Esse ano não, como você comentou das pinturas, favoreceu assim que eles experimentassem essas diferentes possibilidades mais de uma vez, explorassem mais isso por causa do ambiente mesmo. Eles iam usando técnicas que eles já tinham aprendido, explorando, criando coisas novas, ousando, fazendo até o que não tinha pedido, porque eles tinham essa oportunidade, essa liberdade. Coisa que eu nunca tive antes, porque a gente tolhe isso.

Eles nunca conseguiriam se fosse na minha sala de aula antes. Isso pra mim foi muito positivo. Acho que isso foi o que marcou mais mesmo. E pra mim também o fato de poder acompanhar as crianças mais de perto nas atividades, até a forma de interferir em algumas situações.

Essa significativa alteração na prática da educadora pode, em grande parte, ser atribuída à capacidade que foi desenvolvendo de re-significar suas ações a partir do processo reflexivo. Vários seriam os exemplos desse novo olhar da educadora para o fazer infantil. Comentando sobre uma atividade do final do ano a educadora disse ter ficado orgulhosa das produções das crianças, que verificava a qualidade da ação e o empenho para a realização por parte delas e, mesmo sem demonstrar ainda plena consciência de sua ação enquanto mediadora, deixa claro em sua fala como conseguiu atuar positivamente neste aspecto: 
No dia da árvore de natal, que eu fiquei colocando o que eles tinham feito de diferente, aí já não cabia mais na porta e eles vieram: "- Poxa vida, mas por quê? Ainda tem pra colocar, você não vai colocar tudo?" Então eles gostavam muito disso, tudo que eles faziam eles sabiam que era aceito.

Isso é sempre positivo, saber que o que você faz é aceito, é admirado pelo grupo (entrevista de dezembro de 2006).

A riqueza de detalhes, o prazer e o envolvimento com que estas crianças realizaram esta atividade evidencia quanto estão pertinentes e contextualizadas essas observações da educadora. Os trabalhos se espalharam por toda a sala e, como mostram as fotos abaixo, as crianças decidiram montar na porta uma árvore feita com o recorte do contorno das suas mãos ${ }^{41}$. Alguns fizeram estrelas e as decoraram usando colagens, diferentes técnicas e materiais de pintura. Outros locais da sala tinham produções diferentes, mas também se via o protagonismo, o exercício de liberdade e criatividade das crianças.

Como ilustração, seguem algumas atividades realizadas:
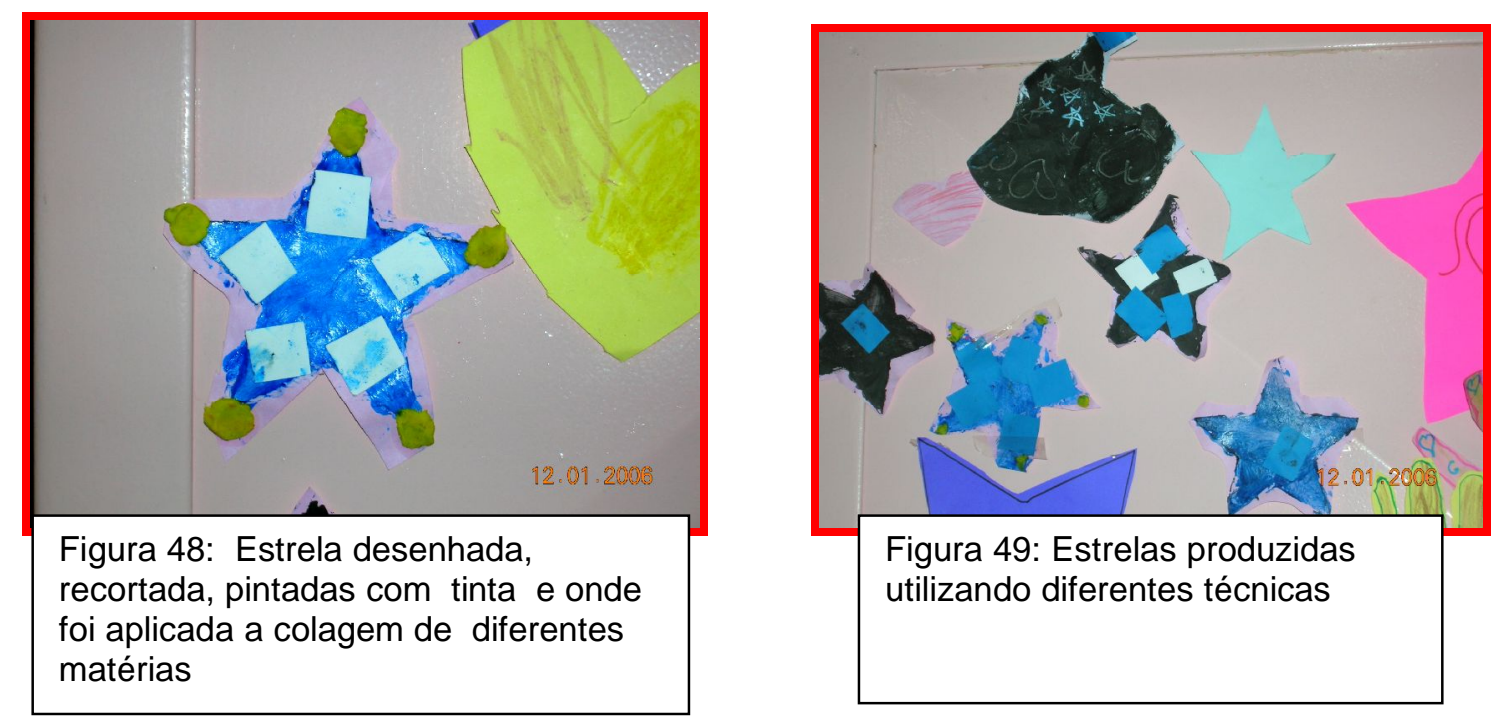

\footnotetext{
${ }^{41}$ A educadora de outro agrupamento havia proposto essa atividade para as crianças de seu agrupamento e, vendo os resultados obtidos pelos colegas, as crianças do agrupamento da educadora Luciana, decidiram fazer também sua árvore.
} 


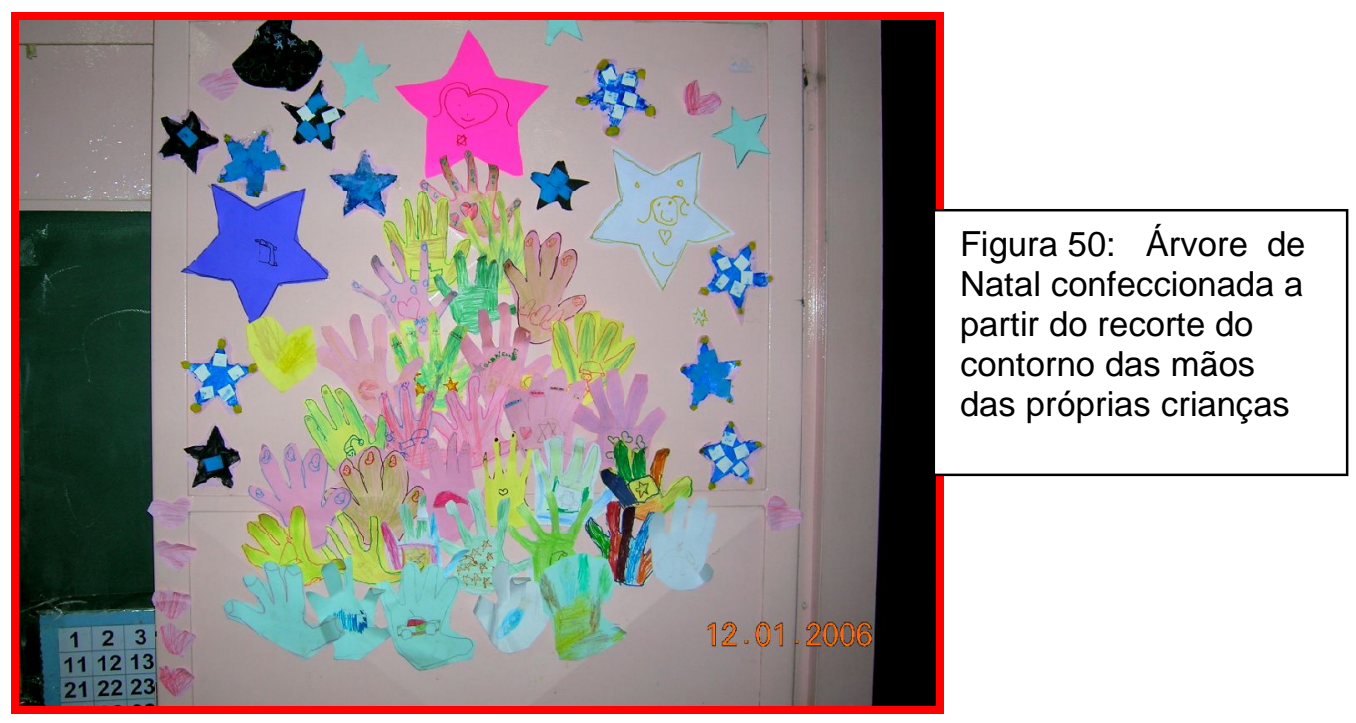

Observações da pesquisadora de que a educadora tinha maior riqueza de detalhes quando ia se referir à ação de uma determinada criança, enfatizando com clareza suas dificuldades e conquistas, foram confrontadas com a opinião da própria educadora sobre isso. Luciana, quando questionada, afirmou acreditar que seu olhar estava mais atento mesmo com o passar do tempo. Em entrevista de dezembro de 2006, ela aponta:

[...] Eu acho que eu conheço mais as crianças, eu posso dizer muito mais a respeito deles do que eu diria de outras crianças que já permaneceram um ano comigo.

[...] Eu sei muito mais o que eles gostam, as preferências; numa atividade livre o que eles escolhem, quais as opções deles, até quando eu ia propor alguma atividade eu sabia quem eu ia precisar ajudar, quem não ia precisar...

[...] Era até legal por que eu sabia que tinha 3, 4 crianças e iam ter um pouco mais de dificuldade pra fazer aquela atividade, por exemplo, eu chamava junto, eu acho que isso é muito mais interessante...

[...] Era coisa que assim antes eu não conseguia interferir, eu não conseguia estar junto...

[...] Antes parece que era assim, era tudo no grupo, era (como vou explicar?) era uniforme, parecia que tinha um padrão. E agora, não, parece uma coisa mais individualizada em alguns momentos. Você consegue acompanhar algumas coisas, consegue interferir de alguma forma nas atividades.

Observou-se que a educadora, com o transcorrer do processo de pesquisa-ação na vertente da tutoria entre pares, a partir do processo reflexivo que partia da análise da prática realizada na sua sala, foi cada vez mais tomando para si e dividindo com 
as crianças a posição de autoria do processo de ensino-aprendizagem e, desta forma, responsabilizando-se pelo que ocorria neste espaço educativo. Dizia ela que "às vezes (antes ${ }^{42}$ ) eu tinha a sensação de que as coisas eram daquele jeito e eu não ia conseguir mudar muitas coisas" (Entrevista de dezembro de 2006).

A necessidade de um papel diferenciado atribuído ao educador que a educadora Luciana já percebia ser necessário logo no início da parceria, diz ela em abril num dos encontros de tutoria: "exige outro tipo de comportamento do educador frente ao trabalho. A gente deixa de ser o centro do trabalho e passa, em alguns momentos a ser mais um" (encontros de tutoria abril 06). Foi ficando cada vez mais visível e sua prática, bem como suas observações, refletiam isso. Em entrevista de outubro de 2006 ela afirma:

[...] acho que o papel do professor torna-se outro dentro dessa proposta, em alguns momentos. Você está ali, mas não é o centro das atenções na maior parte do tempo. Antes parecia que você tinha o controle de tudo que estava acontecendo na sala, agora não é sempre que você tem esse controle. Lidar com isso às vezes é mais complicado.

Este processo reflexivo, construído em parceria, trouxe marcas importantes tanto para a educadora quanto para a pesquisadora, que acabaram, no caso da educadora, transparecendo muito explicitamente em suas práticas e em suas análises sobre elas.

Quando questionada sobre o que julgava ter incorporado na sua prática, relacionado à proposta de reorganização dos espaços e atividades e ao olhar dessas práticas à luz do processo de pesquisa colaborativa, Luciana diz que ficaram marcas em relação a essa experiência. Enfatiza isso afirmando que "indiferente de... algumas coisas darem errado, é uma coisa que vou continuar fazendo, porque voltar acho que eu não volto mais a fazer o que eu fazia... dentro do que eu trabalhava era muito chato para elas (as crianças ${ }^{43}$ )" (Entrevista outubro 2006).

Refletindo sobre sua postura junto às crianças, diz na entrevista de dezembro de 2006:

[...] esses dias eu estava pensando, esse ano eu disse muitos "sins" pras crianças, pode tal coisa, pode tal coisa, eu posso fazer isso agora e isso é muito bom, principalmente quando se trata de estar trabalhando.... é muito

\footnotetext{
${ }^{42} \mathrm{O}$ termo antes, aqui incluído, é uma observação da pesquisadora relativa à interpretação do contexto do qual a fala foi extraída.

${ }^{43}$ Inferência da pesquisadora a partir do contexto em que este excerto estava inserido na entrevista.
} 
gostoso quando você pode dizer muitos "sins": você pode fazer tal coisa, pode isso...

Eu acho que você passa a olhar, a acreditar que ela pode participar muito mais das atividades... ela está ali experimentando diferentes possibilidades, diferentes atividades...

Você deixa de ser o centro das atenções e isso pra mim foi muito bom, eu nunca mais quero voltar a estar no centro das atenções e eu não sei se eu tivesse que voltar pra uma sala como era antes como seria. É lógico que você vai se adaptar, mas eu acho que algumas coisas seriam diferentes, acho que eu não conseguiria voltar da mesma forma.

O trajeto que leva à mudança passa, ao que tudo indica, pelo caminho da resignificação das práticas pedagógicas através da reflexão sobre os fazeres junto à criança pequena. Reflexão que, apesar de particular, precisa deixar de ser individual, deve ser negociada através de outros prismas, outros e diferenciados olhares, numa construção contínua, conjunta e consistente.

Oliveira-Formosinho (2007, p. 14) vem dizer:

Convocar crenças e valores, analisar práticas e usar saberes teóricos constitui um movimento triangular de criação de um "espaço ambíguo" - o espaço da pedagogia - que nos reenvia para uma triangulação praxiológica. Ser profissional reflexivo é fecundar, antes, durante e depois da ação, as práticas nas teorias e nos valores, interrogar para ressignificar o já feito em nome da reflexão que constantemente o restitui.

Acredita-se que educar seja tarefa demasiadamente complexa e importante demais para que o educador possa julgar-se capaz de fazê-lo sem mediação dos demais membros da sociedade. Se ainda não fomos capazes de incluir neste processo todos os atores que julgamos necessários, que possamos pelo menos fazê-lo, inicialmente, com os pares que encontramos disponíveis na unidade educacional ou ligados a ela. Foi nessa perspectiva que se inseriu a parceira da pesquisa relacionada ao eixo 1 aqui apresentado.

\subsection{EIXO 2 - Prática pedagógica: estudo sobre o envolvimento das crianças nas atividades}

No capítulo 3 tratou-se da questão do envolvimento. Laevers (2000) afirma que em qualquer atividade da criança se é capaz de identificar o envolvimento. 
Porém, nas crianças menores existe um espaço muito claro para que o envolvimento seja vivenciado, a sua brincadeira.

Essa afirmação do autor e de outros teóricos como Vygotsky e Leontiev (2000), aliada às primeiras observações, levaram a pesquisadora a optar, num primeiro momento, pela realização das observações de envolvimento da criança apenas no momento da brincadeira espontânea. Essa opção parecia adequada, pois na prática pedagógica acompanhada a brincadeira tinha forte presença, estando incluída na rotina diariamente no momento de trabalho no espaço reorganizado, conforme explicitado anteriormente.

Na pesquisa qualitativa, segundo afirmam Bogdan e Biklen (1994, p. 50) "O investigador qualitativo planeja utilizar parte do estudo para perceber quais são as questões mais importantes. Não presume que sabe o suficiente para reconhecer as questões importantes antes de efetuar a investigação."

Esse processo de redimensionamento da ação ocorreu no caso das observações de envolvimento. Durante o acompanhamento da prática pedagógica e também graças a valiosas colaborações ocorridas no processo de qualificação, optou-se por, a partir de setembro de 2006, acompanhar (utilizando o conceito e a Escala de Envolvimento da Criança) também as atividades orientadas que eram propostas pela educadora.

Para acompanhar o efeito da prática pedagógica sobre as crianças foi utilizada a Escala de Envolvimento da Criança - LIS-YC, proposta por Ferre Laevers (1994). Esta opção já foi anteriormente justificada no capítulo que trata das questões relativas à qualidade da educação infantil, em que se considera o envolvimento da criança pequena na atividade que realiza como um dos indicadores dessa qualidade.

O objetivo do uso da Escala de Envolvimento era de analisar a prática pedagógica efetuada e, na perspectiva de qualidade como processo contínuo de aprimoramento, alcançar uma progressiva melhoria do trabalho realizado junto às crianças. Nessa linha, fez sentido discutir com a educadora do agrupamento o envolvimento apresentado pelas crianças nas diferentes atividades propostas. $O$ estudo e a utilização da Escala de Envolvimento da Criança foram integrados nesta pesquisa. Laevers (1994) corrobora esta escolha quando afirma que:

Os educadores de infância devem ser capazes de fazer apreciações fundamentadas e críticas sobre a qualidade da educação e da aprendizagem que proporcionam ás crianças [...] estamos conscientes da 
necessidade de se promoverem boas relações de trabalho entre colegas, contudo devemos salientar a importância de realizar observações o mais objetiva e abertamente possível para que constituam um meio eficaz para desenvolver a qualidade de sua prática.

A Escala de Envolvimento da Criança - LIS-YC foi construída inicialmente para observação de crianças de 3 a 6 anos e comporta uma lista de indicadores característicos de um comportamento de envolvimento e uma tabela de classificação que coloca o nível de envolvimento numa escala de 1 a 5 pontos.

Os indicadores são propostos por Laevers (1994) como meios de melhor compreender o fenômeno do envolvimento e não com finalidade de mensuração ou juízo de valor. Seriam como uma "educação do olhar" para melhor compreender e poder então estabelecer mais adequadamente o nível de envolvimento dessa criança na escala que serve de guia para esta análise.

Os indicadores de envolvimento observados foram: a) concentração - a atenção da criança está focada na atividade que realiza; b) energia - a criança investe todo seu esforço físico/mental na atividade; c) criatividade e complexidade - a criança dá seu toque pessoal e original à atividade que realiza, mobiliza de livre vontade o melhor de sua capacidade; d) expressão facial e postura - fisicamente pode-se notar a criança realmente interessada no que faz através da fala, descontração, olhos brilhantes, tensão muscular etc.; e) persistência - é a duração da concentração na atividade que realiza: crianças realmente envolvidas dificilmente se distraem com o que ocorre a sua volta e tem dificuldade em abandonar a tarefa; f) precisão - estão atentas aos pormenores da tarefa, demonstram cuidado com o que fazem e melhoram sua performance devido à motivação com a qual realizam a atividade; g) tempo de reação - estão atentas e reagem com rapidez aos estímulos; h) linguagem - importância da atividade para a criança poder ser observada pelo que ela fala da mesma, pela solicitação de repetição; i) satisfação - demonstram grande satisfação com os resultados alcançados na atividade.

Conforme demonstra o quadro 9 os níveis de envolvimento são 5 , sendo o escore 5 atribuído ao maior grau de envolvimento da criança na atividade. Esses níveis variam de acordo com a duração e intensidade da atividade e devem ser estabelecidos considerando-se também os indicadores anteriormente mencionados. 
Quadro 10 - Escala de Envolvimento da Criança - níveis de envolvimento

\begin{tabular}{|c|l|}
\hline Nível & \multicolumn{1}{|c|}{ Descrição } \\
\hline $\mathbf{1}$ & $\begin{array}{l}\text { SEM ATIVIDADE: atividades são simples, repetitivas; criança tem atitudes passivas; } \\
\text { olhar está vago; basicamente há ausência de concentração interior. }\end{array}$ \\
\hline 2 & $\begin{array}{l}\text { ATIVIDADE INTERROMPIDA FREQÜENTEMENTE: pelo menos na metade do } \\
\text { período de observação a criança está sem atividade; não há fluxo contínuo na } \\
\text { atividade; pode haver interrupções constantes da tarefa e a criança tem dificuldade } \\
\text { de voltar a ela. }\end{array}$ \\
\hline $\mathbf{3}$ & $\begin{array}{l}\text { ATIVIDADE MAIS OU MENOS CONTíNUA: criança ocupa-se da atividade num nível } \\
\text { rotineiro; distrai-se facilmente; desiste nas primeiras dificuldades; não há ainda total } \\
\text { interesse ou concentração. }\end{array}$ \\
\hline $\mathbf{4}$ & $\begin{array}{l}\text { ATIVIDADE CONTÍNUA COM MOMENTOS DE GRANDE INTENSIDADE: em vários } \\
\text { momentos há aprofundamento das atividades desenvolvidas no nível 3, mesmo que } \\
\text { haja interrupções a atividade é retomada; estímulos externos não conseguem distrair } \\
\text { a criança. }\end{array}$ \\
\hline $\mathbf{5}$ & $\begin{array}{l}\text { ATIVIDADE INTENSA E PROLONGADA: atividade perdura por quase todo período } \\
\text { de observação; criança focada no que faz, estímulos externos são ignorados; devem } \\
\text { estar presentes no mínimo os indicadores de concentração, criatividade, energia e } \\
\text { persistência. }\end{array}$ \\
\hline
\end{tabular}

A análise do envolvimento da criança deve ocorrer, segundo Laevers (1994), a partir da observação de episódios gravados em vídeo, com duração de dois minutos cada. $O$ autor aponta como desejável que sejam coletados 3 episódios não seqüenciais de cada criança durante o dia de filmagem e, se possível, deve-se completar a observação de duas seções numa semana.

No estudo empírico realizado, as gravações em vídeo tiveram a duração de dois minutos em cada episódio. Na maioria das análises para atribuição da média de envolvimento das crianças foram acompanhados de 3 a 6 episódios da atividade em questão.

Em alguns casos em que o acompanhamento desse número de episódios ficou impossibilitado devido ao tempo de execução da atividade, ou relacionado à periodicidade da presença da pesquisadora, optou-se por definir o escore médio a partir de 2 episódios. Essa opção derivou da certeza de que este escore sofreria uma influência inadequada caso os episódios posteriores fossem acompanhados em datas muito distante dos iniciais.

As atividades acompanhadas eram aquelas realizadas durante o período de sala que comportava o momento de trabalho na proposta de Reorganização dos Espaços e das Atividades, cerca de 1 hora e 30 minutos. 
Cuidados essenciais ao bom uso do instrumento foram tomados quando se optou pelo uso da Escala de Envolvimento da Criança. Antes do início da coleta de dados e aplicação do referido instrumento, a pesquisadora participou de dois encontros de pesquisa para reflexão e treinamento no uso desse instrumental ${ }^{44}$. Em setembro de 2006 foram realizados outros dois encontros de pesquisadores que utilizam a escala em seus trabalhos a fim de serem reavaliadas pelo grupo algumas análises prévias feitas individualmente, visando burilar a técnica e aprimorar o olhar desses pesquisadores sobre o fenômeno observado.

Outro cuidado foi desprezar as primeiras filmagens, que tiveram apenas a dupla função de aprimorar a capacidade do pesquisador para realização tanto das filmagens quanto da análise do envolvimento das crianças e simultaneamente habituar as crianças com o equipamento de vídeo e a presença da pesquisadora (enquanto cinegrafista) naquele ambiente. Estes episódios foram descartados e não fazem parte dos conteúdos das análises realizadas.

As observações foram seguidas do preenchimento de ficha própria proposta por Laevers (1994), que se encontra no anexo 3. Neste momento inicial de análise, e pautados nas indicações do autor, os escores de envolvimento foram atribuídos, mas passaram por análises posteriores (duas revisões das imagens de cada episódio) para confirmação do escore atribuído.

No total foram efetuadas gravações e análises de 252 episódios de 2 minutos. Estes episódios foram agrupados em 5 momentos de análise, a saber:

Quadro 11- Cronograma de coleta de observações do envolvimento da criança

\begin{tabular}{|c|l|}
\hline $\begin{array}{c}\text { Momentos } \\
\text { de análise }\end{array}$ & \multicolumn{1}{|c|}{ Datas de Coleta de Dados (2006) } \\
\hline Primeiro & Dias 19 e 26/4 ou 26/4 e 17/5 para os ausentes nas primeiras datas \\
\hline Segundo & Dia $21 / 06$ \\
\hline
\end{tabular}

${ }^{44} \mathrm{O}$ treinamento ocorreu utilizando-se material criado pelo autor para tal e contou com a supervisão da Profá ${ }^{\text {. Dra }}$. Tizuko M. Kishimoto, bem como do apoio dos participantes do grupo de pesquisa Contextos Integrados de Educação Infantil. 


\begin{tabular}{|c|l|}
\hline $\begin{array}{c}\text { Momentos } \\
\text { de análise }\end{array}$ & \multicolumn{1}{|c|}{ Datas de Coleta de Dados (2006) } \\
\hline Terceiro & Dia 30/8 \\
\hline Quarto & Dias 12 e $19 / 09$ \\
\hline Quinto & Dias $13,16,17$ e $21 / 11$ \\
\hline
\end{tabular}

A análise dos episódios de envolvimento junto com a educadora havia sido planejada por ocasião do desenho da investigação, mas não ocorreu devido a variáveis intervenientes relacionadas à agenda da própria educadora e também a greve dos servidores municipais da educação que acabou fechando a escola vários dias e reduzindo o número de reuniões de tutoria inicialmente planejadas. Apesar disso, avaliamos que os estudos deste instrumento realizados nos encontros de tutoria, com a leitura e discussão dos textos de Laevers (1994; 2000) e OliveiraFormosinho (2004) trouxeram resultados significativos: uso dos indicadores de envolvimento para geração de observáveis destinadas ao acompanhamento da ação das crianças e uso dos pressupostos ali presentes para amplificar a capacidade e a qualidade de observação da criança pela educadora Luciana.

No capítulo 3 já foi mencionada a ligação que vários autores apontam entre o envolvimento da criança pequena e a qualidade do contexto educativo. Para Laevers, considerando-se os cinco níveis de envolvimento, a entrada na qualidade é definida pelo escore 3,5 (ponto médio da escala). Portanto, na maioria das análises realizadas neste estudo haverá referência a esse escore, considerando-o, como afirma o autor, que indicaria, naquele momento e para aquela determinada criança, um parâmetro de qualidade do contexto educativo que apresentava. A compreensão é que níveis de envolvimento muito baixos indicam problemas no contexto educativo e, observando estes níveis, torna-se possível tecer considerações sobre a qualidade do trabalho pedagógico ali desenvolvido. 


\subsubsection{Escolha dos sujeitos}

A sala em que a pesquisa se realizou tinha 35 crianças matriculadas e era homogênea do ponto de vista etário, com crianças de 5 anos e 8 meses até 6 anos e 7 meses (contados em março de 2006) ${ }^{45}$.

As observações usadas para aprimoramento da captação de imagens, treinamento da pesquisadora nas suas análises e ambientação das crianças aos equipamentos envolveram 22 crianças, contudo havia a consciência da necessidade de diminuir o número de sujeitos para viabilizar o acompanhamento, considerando o tempo disponível e que as filmagens seriam feitas pela própria pesquisadora. Além disso, Laevers considera como ideal a média de 12 crianças para este acompanhamento.

Para escolher as crianças que seriam os sujeitos da pesquisa foi realizada uma entrevista com a educadora em 14/6/06, em que ela elegeu, entre os matriculados, aqueles que seriam acompanhados em relação ao envolvimento na atividade. Os dados coletados anteriores a esta entrevista foram utilizados para análise, desde que contemplassem os sujeitos indicados pela educadora.

A entrevista aconteceu depois de alguns estudos sobre Laevers e a escala de envolvimento. A escolha dos sujeitos foi posteriormente um dos temas de reunião de formação/tutoria, explicitando então valores, hipóteses e objetivos subjacentes a sua opção.

Entre outros comentários, a educadora Luciana afirmou ter estabelecido critérios para a escolha, como a boa freqüência das crianças ou elegeu algumas crianças que de algum modo a "deixavam mais intrigada", seja por requererem atenção permanente ou por apresentarem certo distanciamento da atividade ou dos colegas. Algumas de suas justificativas foram:

- Para a criança GAB-C: "é super atenta, mas também sempre quer uma atenção só para ela... e parece que presta atenção em muitas coisas ao mesmo tempo, em um milhão de coisas";

- Sobre RO, afirma: "é uma criança bem levada que na hora da atividade tem atitudes bem diferentes do que na brincadeira, ${ }^{\text {,46. }}$.

\footnotetext{
${ }^{45}$ Ver quadro 3, constante no capítulo 4- Metodologia da Investigação

${ }^{46}$ Entrevista com a educadora Luciana realizada em 14/06/06.
} 
Avaliou-se que esse processo de seleção dos sujeitos em que a escolha não se deu com prioridade nos critérios estatísticos foi uma parte muito significativa do processo formativo da educadora, pois exigiu desta um trabalho reflexivo sobre cada criança, suas peculiaridades, sua relação com a aprendizagem, com os outros pares e com a própria educadora. Na fala da educadora já fica aparente este processo, pois ela estava construindo um olhar mais detalhado e verdadeiro para cada criança.

$\mathrm{Na}$ entrevista foram eleitos os seguintes sujeitos: MAT, LU, RO, GAB, TH, JH, $A D, G R A, G A B-C, G A B-R, V A, B I, K A$.

O acompanhamento da pesquisadora ocorria semanalmente entre $15 \mathrm{~h} 00 \mathrm{e}$ 16 h30 no período que foi de março a novembro de 2006. Esses momentos, porém, eram divididos em observações voltadas à análise da prática pedagógica (eixo1) e do envolvimento da criança nas atividades (eixo2 $)^{47}$.

Com os momentos de observação definidos pela proposta pedagógica e também pela disponibilidade da pesquisadora, a falta de algumas crianças durante os momentos de observação e filmagem fez com que dos sujeitos inicialmente eleitos as crianças MT e BI fossem eliminadas e substituídas pelas crianças GAB-R, MI, NA, SAB, BR, EV.

No total a amostra ficou com a seguinte configuração: oito meninos (LU, RO, $\mathrm{GAB}, \mathrm{JH}, \mathrm{TH}, \mathrm{AD}, \mathrm{BR}, \mathrm{EV}$ ) e oito meninas (GAB-C, GAB-R, VA, KA, NA, GRA, SAB, $\mathrm{MI})$.

Em algumas análises realizadas, reduziu-se o número de sujeitos da amostra, considerando-se a necessidade de os dados serem suficientemente consistentes a fim de subsidiar adequadamente as interpretações e também as conclusões delas decorrentes.

\subsubsection{A brincadeira espontânea e o envolvimento da criança: registros das observações}

Considerou-se brincadeira toda a atividade iniciada espontaneamente pela criança, que tenha ocorrido no espaço reorganizado da sala, dentro do horário destinado para uso deste espaço na rotina, que não tenha sofrido influência direta da educadora (proposição da atividade ou confecção conjunta) e que tivesse as

\footnotetext{
${ }^{47}$ Conforme já descrito no quadro 6, capítulo 5 deste trabalho.
} 
regras, interações, situações imaginárias e/ou materiais estabelecidos pelas própria criança. ${ }^{48}$

A brincadeira espontânea da criança foi acompanhada para análise do envolvimento em 12 crianças nos cinco momentos (abril, junho, agosto, setembro e novembro) e para quatro sujeitos em apenas dois momentos (abril e novembro). No total 16 crianças tiveram esta atividade observada.

Em abril, das dezesseis crianças acompanhadas na pesquisa, dez obtiveram escore de envolvimento na atividade entre 4 e 5; cinco obtiveram escore entre 3,5 e 4 e apenas um obteve escore inferior a 3,5.

Em novembro, do mesmo grupo de dezesseis, doze obtiveram escore entre 4 e 5, uma criança obteve entre 3,5 e 4 e três obtiveram escore abaixo de 3,5. Oito crianças obtiveram escore acima de 4 e quatro obtiveram acima de $\mathbf{3 , 5}$ nos dois momentos de observação.

Apesar da média de envolvimento do grupo ter um escore médio alto $(\mathbf{4 , 2})$, a análise comparativa dos momentos de abril e novembro aponta que $50 \%$ (cinqüenta por cento) das crianças apresentaram ganhos significativos nos escores de novembro em comparação com seus escores de abril.

Gráfico 1- Envolvimento da criança na brincadeira - escores médios

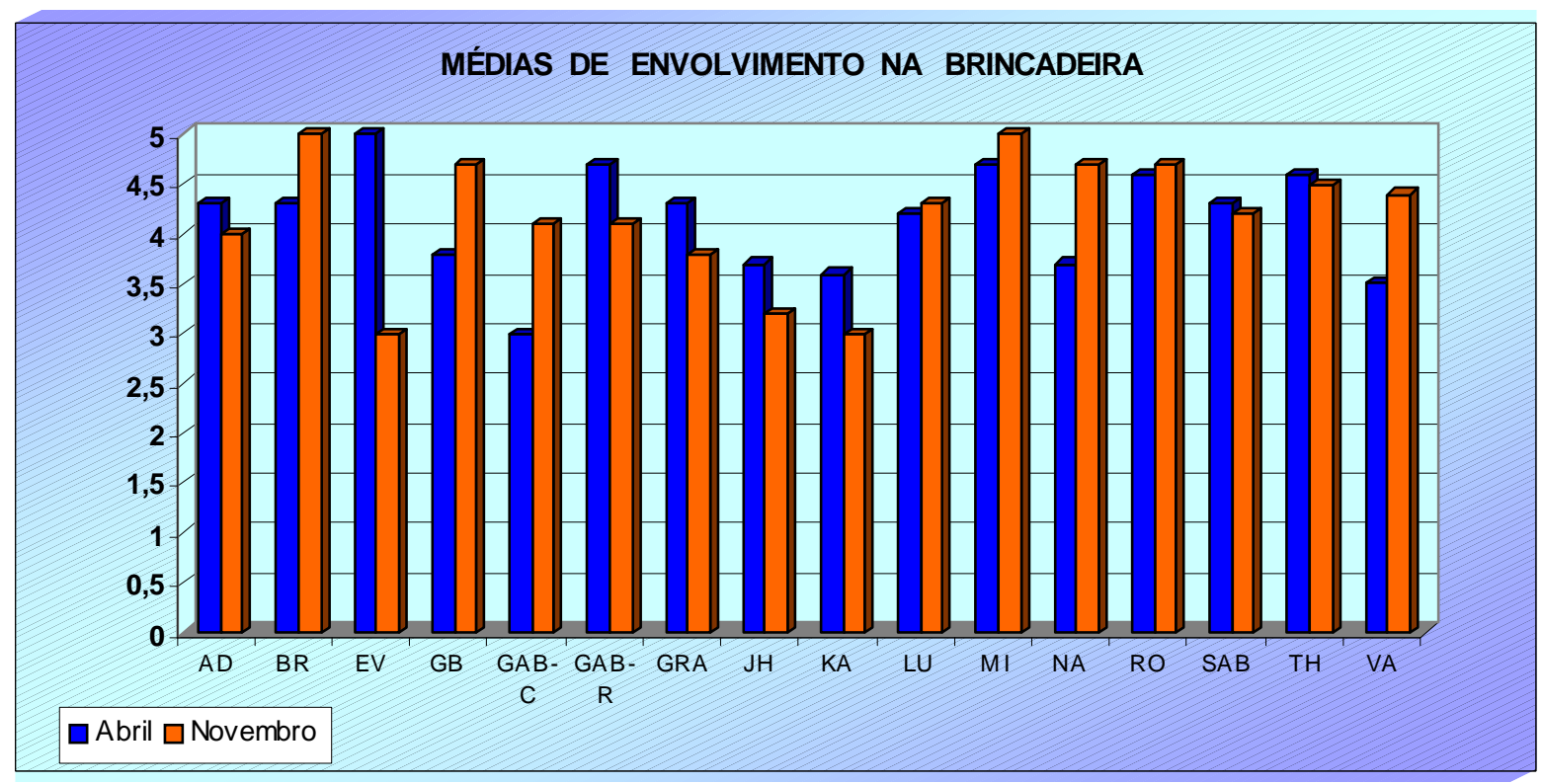

\footnotetext{
${ }^{48}$ O capítulo 3 deste estudo trouxe maiores esclarecimentos sobre as características da brincadeira e o referencial teórico adotado para subsidiar tal definição.
} 
Não houve em nenhum dos aspectos analisados alterações significativas que pudessem indicar que questões relacionadas ao gênero das crianças pudessem ter exercido qualquer influência nos escores obtidos.

Das dezesseis crianças, sujeitos da pesquisa, doze mantiveram freqüência sistemática às aulas durante os momentos em que as observações e filmagens para análise do envolvimento foram realizadas. Desta forma, com elas foi possível realizar análises comparativas em um número maior de momentos.

Do grupo destas doze crianças, seis meninos e seis meninas, a média de envolvimento foi de 4 em abril e junho, 3,9 em agosto, 3,7 em setembro e 4,1 em novembro.

A média individual ficou como consta No quadro abaixo:

Quadro 12: Envolvimento das crianças na brincadeira - médias mensais individuais

\begin{tabular}{|c|c|c|c|c|c|c|c|c|c|c|c|c|}
\hline $\begin{array}{c}\text { CRIANÇA } \\
\text { Mês }\end{array}$ & AD & GB & $\begin{array}{c}\text { GAB- } \\
\mathbf{C}\end{array}$ & $\begin{array}{c}\text { GAB- } \\
\mathbf{R}\end{array}$ & GRA & JH & KA & LU & NA & RO & TH & VA \\
\hline Abril & 4,3 & 3,8 & 3,0 & 4,7 & 4,3 & 3,7 & 3,6 & 4,2 & 3,7 & 4,6 & 4,6 & 3,5 \\
\hline Junho & 3,0 & 5,0 & 5,0 & 5,0 & - & - & 3,0 & 4,0 & 3,0 & 4,7 & 4,3 & 3,5 \\
\hline Agosto & 5,0 & - & - & - & 4,0 & - & 3,0 & 5,0 & 3,0 & 4,7 & 4,5 & 2,5 \\
\hline Setembro & 5,0 & - & - & - & - & 3,0 & 3,0 & 5 & 3,0 & 4,0 & 4,5 & 2,5 \\
\hline Novembro & 4,0 & 4,7 & 4,1 & 4,1 & 3,8 & 3,2 & 3,0 & 4,3 & 4,7 & 4,7 & 4,5 & 4,4 \\
\hline
\end{tabular}

Nota-se que das 50 médias mensais atribuídas, 13 encontram-se abaixo de 3,5 e 37 acima desse escore, sendo que 30 estão com valores atribuídos entre 4 e 5. No computo total das dezesseis crianças acompanhadas, as médias anuais também se encontram significativamente altas sendo que doze delas apresentaram média anual igual ou superior a 4. Das quatro crianças com médias anuais inferiores a 4, as meninas NA e VA apresentaram evolução significativa, ficando com escore no mês de novembro em 4,7 e 4,4 respectivamente. 
Gráfico 2 - Envolvimento das crianças na brincadeira - médias anuais

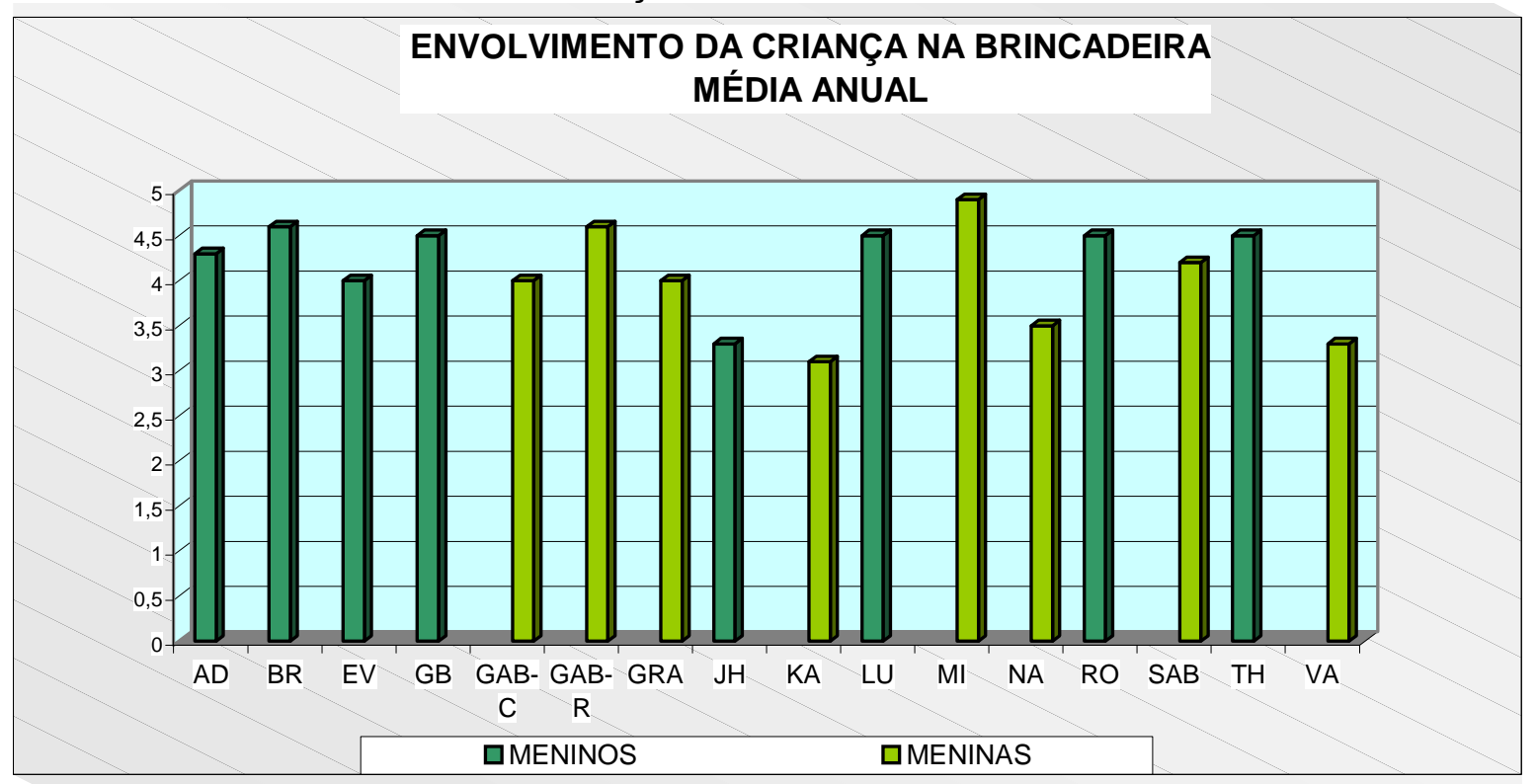

A presença da brincadeira na atividade diária, iniciada e mantida a partir do interesse e iniciativa da criança, e a possibilidade de alterar a ação, seguindo seus desejos e necessidades, podem ser apontados como elementos desencadeadores de níveis mais altos de envolvimento. Nas observações da pesquisadora, percebeuse que algumas crianças passaram até 50 minutos com grande grau de envolvimento na realização de uma mesma brincadeira, enquanto outras tiveram neste mesmo período de tempo quatro ou mais atividades diferentes, sem que, necessariamente, apresentassem níveis inferiores de envolvimento na ação realizada.

\section{Recuperando alqumas questões}

Observando os níveis de envolvimento altos alcançados pelas crianças no momento da brincadeira, pode-se pensar que essa classe tenha uma estrutura física, material, de suporte do adulto, bem como uma proporção adulto criança adequada à faixa etária que atende. Contudo, esta não é uma verdade completa.

É importante lembrar que se trata de uma Escola Municipal de Educação Infantil da cidade de São Paulo, localizada na periferia da capital, com 35 alunos para apenas uma educadora e que, embora tenha o espaço reorganizado, encontrase ainda em defasagem em termos de espaço adequado e disponibilidade de 
materiais, se consideradas experiências de outros modelos pedagógicos que privilegiam a ação da criança, como High Scope e Reggio Emilia.

O ambiente tem uma organização já diferenciada da maioria das escolas de educação do município, comportando variedade de materiais e tendo uma rotina que privilegia a mobilidade e o protagonismo da criança, além de certo respeito pelas escolhas das crianças, principalmente nos momentos de trabalho reorganizado. Porém, a estrutura é em parte inadequada para a ação da criança (apertada, ruidosa e com pouco apoio do adulto durante a ação), contudo essa configuração não impossibilitou a atribuição de escores altos de envolvimento, visto que na proposta de Laevers (1994, 1996 e 2000) o que define o nível de envolvimento que deve ser atribuído à criança são os indicadores propostos,já mencionados anteriormente neste trabalho, se a ação da criança é contínua ou não e quais as características desta ação.

Verificou-se, corroborando o apontado por Csikszentmihalyi (1999), que quando havia um nível maior de envolvimento da criança, ou estado de fluxo, como aponta o autor, a maioria dos apelos externos era ignorada ou trazia interferências pouco significativas para a ação que a criança estava desenvolvendo e não pareciam afetar seu envolvimento de maneira definitiva.

Embora os escores fossem atribuídos privilegiando-se a ação que a criança estava realizando e quanto se mostrava "comprometida" com sua tarefa, as observações possibilitaram reforçar a crença na hipótese de que as crianças que obtiveram menores níveis de envolvimento seriam muito beneficiadas caso a estrutura espacial e a proporção adulto criança fosse alterada, possibilitando dessa maneira uma maior mediação do adulto. Seria interessante que pesquisas futuras iluminassem estas questões.

\subsubsection{A atividade proposta pela educadora e o envolvimento da criança: registros das observações}

Avaliou-se que, já que a prática pedagógica da educadora era acompanhada, sendo alvo de análise no processo de tutoria entre pares, e as alterações que realizava no contexto educativo afetavam diretamente as ações da criança e, ainda, considerando que ocorriam mudanças muito significativas nas atividades propostas, 
conforme já apontamos na análise do eixo 1 dessa pesquisa, seria adequado o acompanhamento das crianças nas atividades espontâneas e também em outros momentos, como por ocasião da realização de atividades propostas e orientadas pela educadora.

O acompanhamento das atividades orientadas iniciou-se em agosto e o escore médio foi atribuído a partir dos episódios observados, independentemente de sua quantidade, considerando-se que nem todas as crianças realizavam a atividade orientada no dia em que aconteciam as observações da pesquisadora e as gravações em vídeo.

Os escores atribuídos para estas atividades foram os seguintes:

Gráfico 3 - Escore médio de envolvimento nas atividades propostas pela educadora.

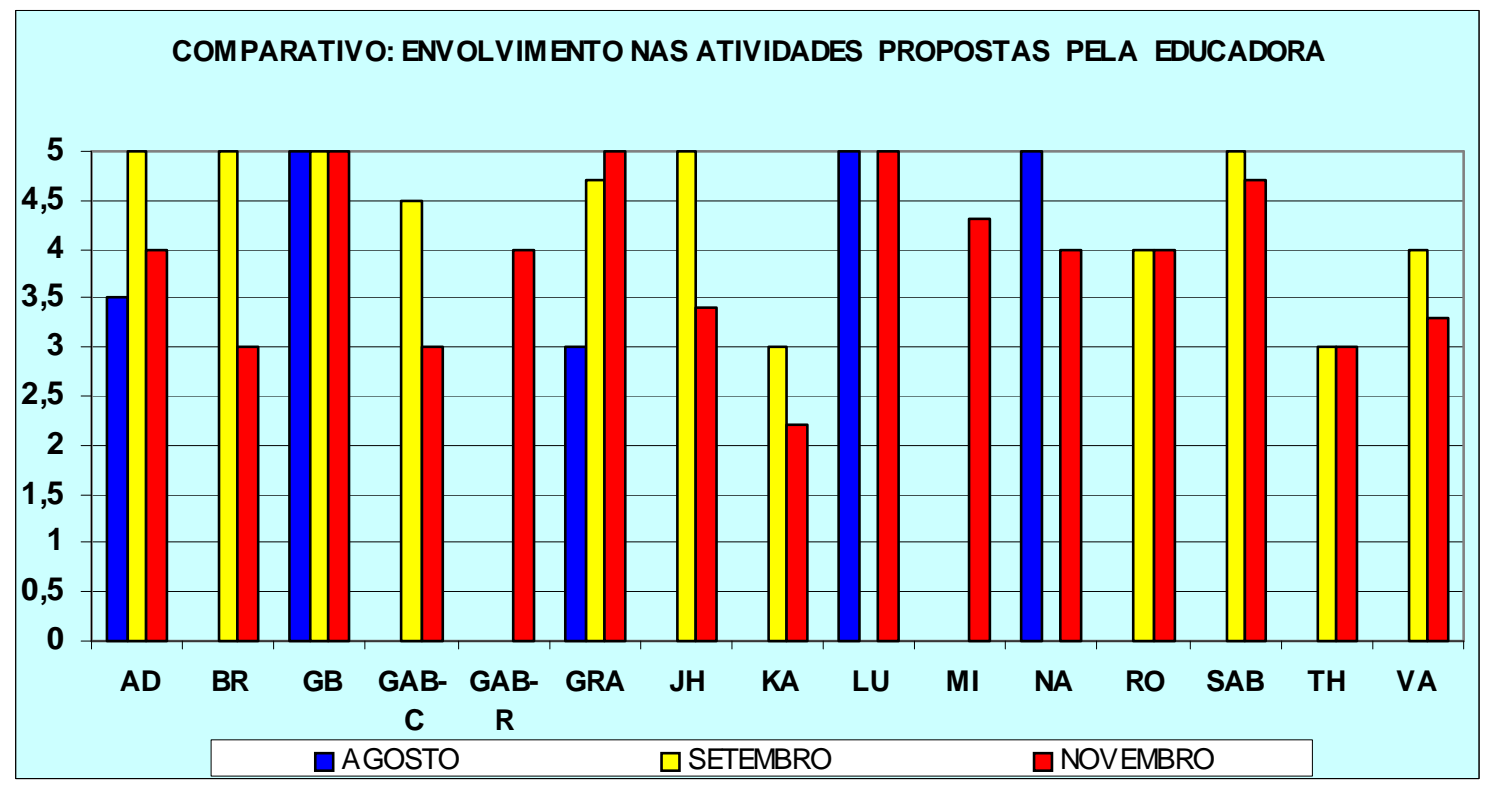

Os dados apontam que, neste caso, o envolvimento das crianças era passível de ser influenciado em maior grau pelas questões derivadas da ação da educadora do que no caso da brincadeira espontânea, tanto que a característica de progressivo aumento do escore de envolvimento lá apresentado não se confirmou em relação a estas atividades.

Podemos perceber que em onze das quinze crianças acompanhadas, os escores mais altos aparecem relacionados com as atividades propostas pela educadora no mês de setembro e não em novembro. 
Apesar disso, dos trinta e dois escores atribuídos para a realização das atividades planejadas e orientadas pela educadora, apenas dez ficaram abaixo de 3,5 , sendo que $69 \%$ dos sujeitos obteve escores entre 4 e 5 . Na média do semestre apenas duas das quinze crianças obtiveram escore inferior a 3,5.

Gráfico 4 - Envolvimento nas atividades propostas pela educadora- médias de Agosto a Novembro

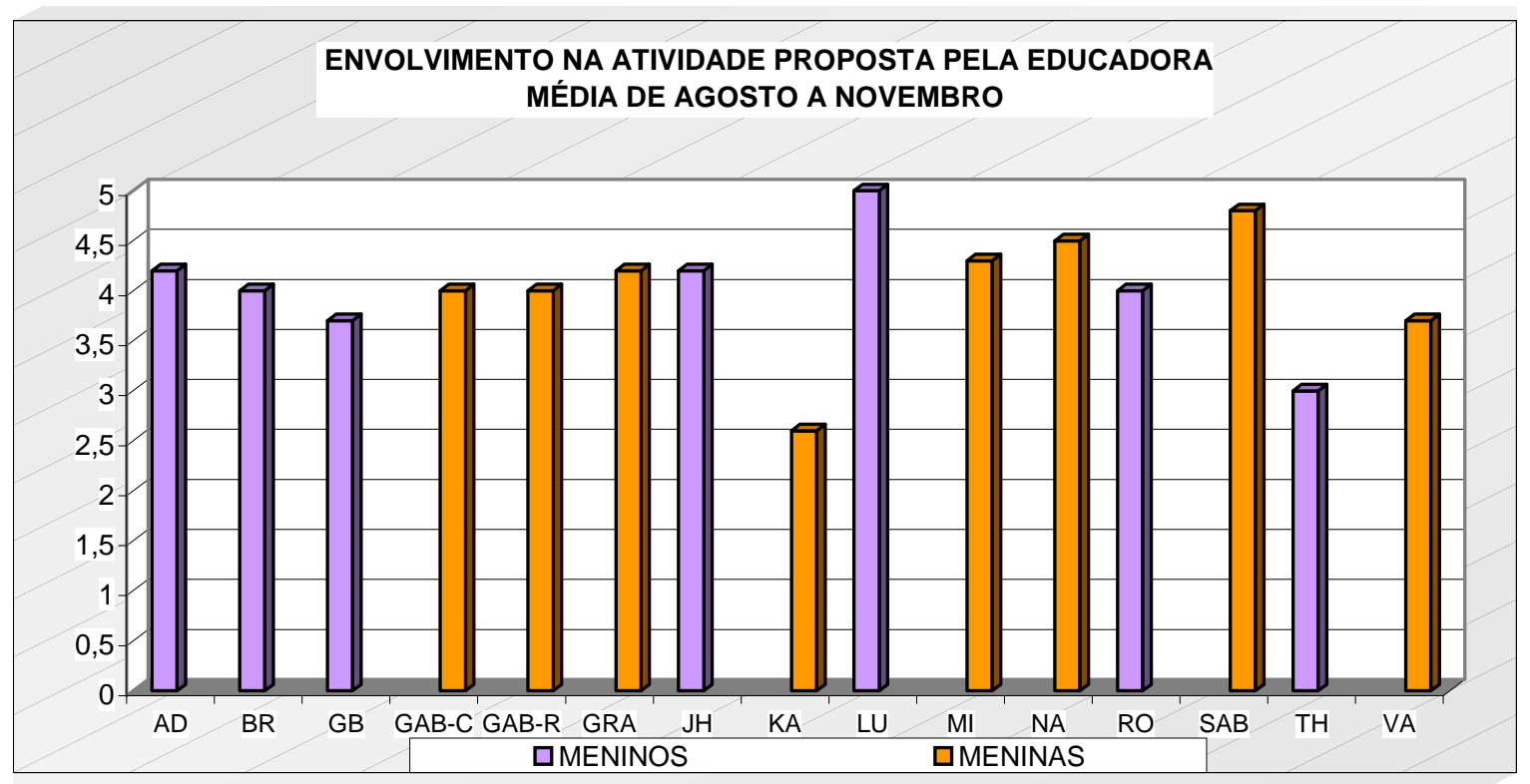

Também nesse caso não houve relação que pudesse ser claramente estabelecida entre os escores e o gênero das crianças observadas.

Vale ressaltar que, embora esses escores sejam altos e realmente apontem a realidade observada, partiram de observações realizadas a partir do final de agosto, sendo que a maioria dos episódios observados se concentraram em setembro e novembro. Nessa altura do ano letivo, conforme demonstrado nos comentários relacionados ao EIXO 1 prática pedagógica, a educadora já estava propondo atividades diferenciadas das do início do ano, agora planejadas levando em conta a ação da criança, seus interesses e suas possibilidades de escolha.

Os diários de campo da pesquisadora evidenciam essa questão e corroboram essa perspectiva de evolução das propostas que eram potencialmente desafiadoras e iam, cada vez mais, em direção ao interesse das crianças.

O próprio Laevers (2000 p. 311) afirma que existem dez princípios que devemos observar quando analisamos uma prática pedagógica. Estes princípios 
podem servir de direcionamento a nossas ações para a conquista da progressiva qualidade do atendimento a infância. São eles:

1- dividir a sala em cantos atrativos;

2- controlar o material destes cantos fazendo modificações (incluindo, excluindo, alterando);

3- introduzir materiais e atividades não convencionais;

4- observar as crianças, identificando interesses e propondo atividades a elas relacionadas;

5- apoiar as atividades das crianças com intervenções enriquecedoras, estímulos, etc.;

6- estimular a iniciativa das crianças e apoiá-las com regras e acordos;

7- estimular sua relação com cada criança e entre as crianças e tentar melhorá-la;

8- propor atividades que auxiliem a criança a explorar o mundo dos sentimentos, valores e experiências;

9- reconhecer as crianças com problemas socioemocionais e buscar intervenções que garantam seu bem-estar;

10- reconhecer crianças com dificuldades particulares de desenvolvimento e ajudá-las por meio de intervenções que visem aumentar sua implicação nos domínios ameaçados.

Desses princípios de ação, também analisados com a educadora Luciana em momentos de tutoria, avalia-se que ela ia fazendo grandes investimentos e visíveis progressos, principalmente nos itens 3 a 7 .

Retomando observações da pesquisadora, relacionadas ao primeiro semestre, acredita-se que as atividades propostas naquele período não obteriam escores altos, ficando bem aquém dos obtidos no segundo semestre, mas não há dados advindos da observação do envolvimento das crianças nas atividades orientadas anteriores ao segundo semestre que possam corroborar esta hipótese.

$\mathrm{Na}$ análise comparativa entre os níveis de envolvimento das crianças nas atividades propostas/orientadas pela educadora e os escores atribuídos quando da 
realização de brincadeiras espontâneas é possível eleger interessantes questionamentos.

Observando os escores de setembro percebem-se escores altos atribuídos tanto à atividade quanto à brincadeira. $\mathrm{O}$ número, porém, de sujeitos em que a comparação foi possível (apenas seis dos dezesseis) não foi considerado representativo da amostra total para possibilitar o estabelecimento de relações mais concretas.

O mês de novembro trouxe uma série de dados interessantes. Das quinze crianças acompanhadas, apenas dez apresentaram escores superiores, tanto na brincadeira quanto na atividade orientada. $\mathrm{Na}$ comparação dos escores obtidos percebemos também que nove das quinze crianças apresentaram escores maiores na brincadeira espontânea, enquanto apenas quatro o fizeram em relação à atividade orientada.

Gráfico 5 - Médias do mês de Novembro - brincadeiras e atividades orientadas

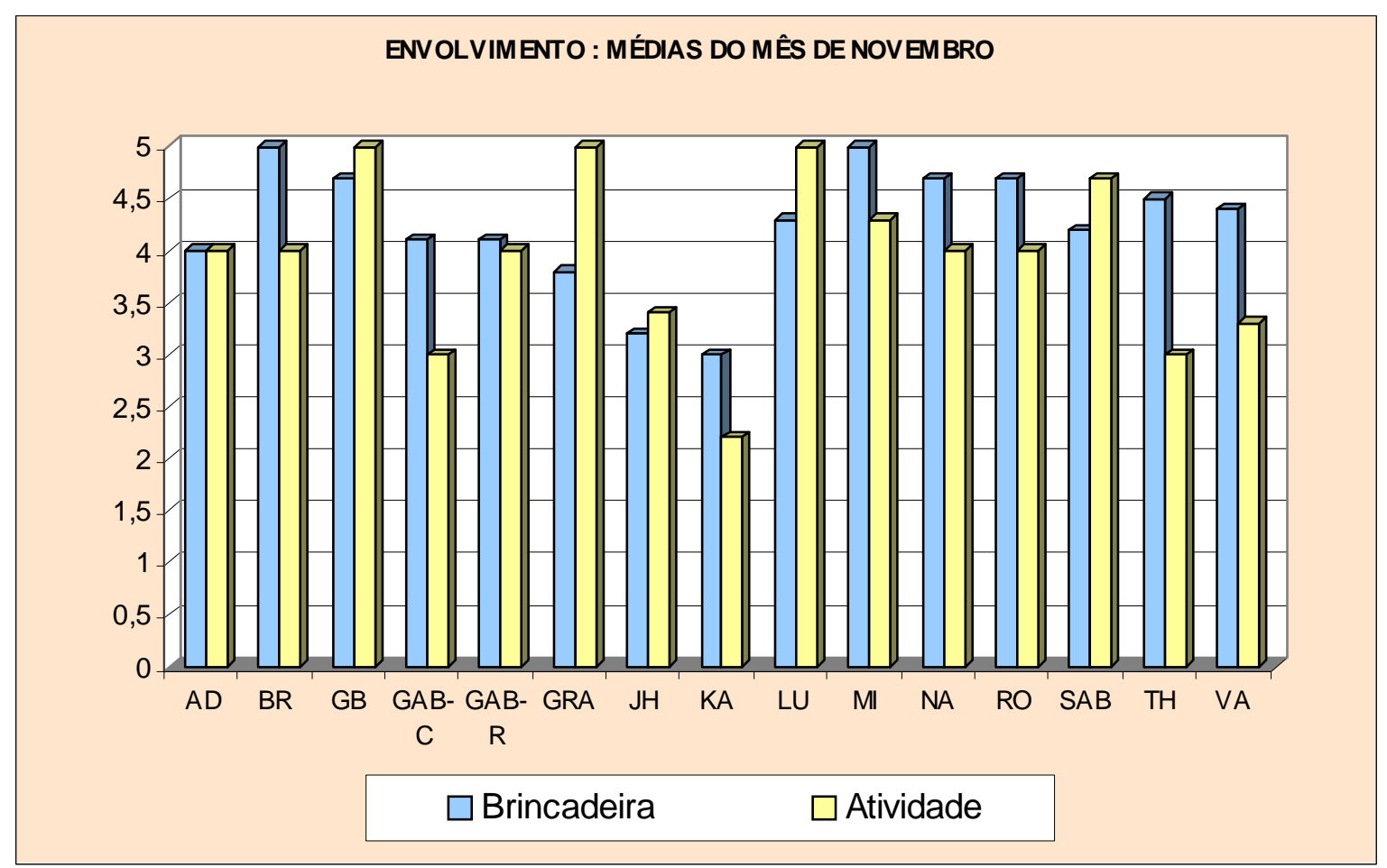

Outro fator significativo é que das cinco crianças que apresentaram escores mais baixos na atividade, entre 2 e 3,5 (GAB-C, JH, KA, TH, VA), três obtiveram escores entre 3,5 e 4,5 (GAB-C, TH, VA) na brincadeira espontânea. Uma obteve 
escores melhores na brincadeira, embora ainda abaixo de 3,5 (KA) e apenas um deles obteve melhores resultados na atividade orientada do que na brincadeira $(\mathrm{JH})$.

Estendendo-se essa análise aos meses de setembro e novembro, verificou-se que das quarenta e nove médias atribuídas, $74 \%$ das atividades orientadas e $77 \%$ das brincadeiras acompanhadas na pesquisa tiveram escores de envolvimento superiores a 3,5. No quadro 18 observa-se que as atividades orientadas tiveram mais escores atribuídos, mas as proporções permanecem as mesmas.

Gráfico 6- Envolvimento na brincadeira - média de Setembro e Novembro
Gráfico 7 - Envolvimento nas atividades orientadas - média de Setembro a Novembro.
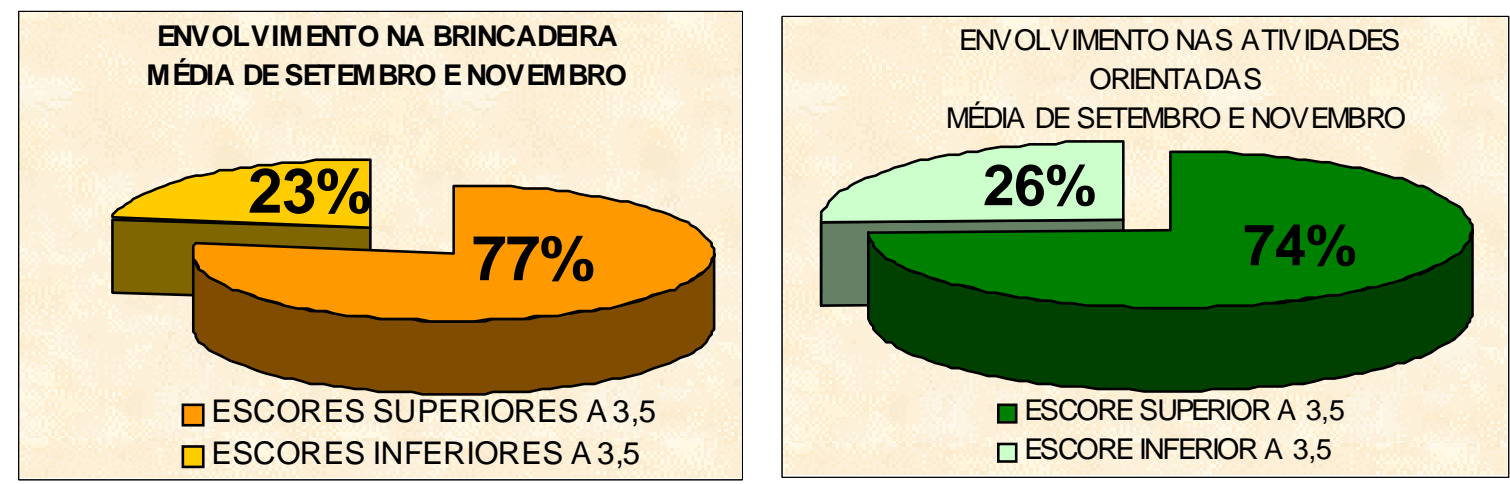

Gráfico 8- Comparativo da média de envolvimento nas brincadeiras e atividades orientadas

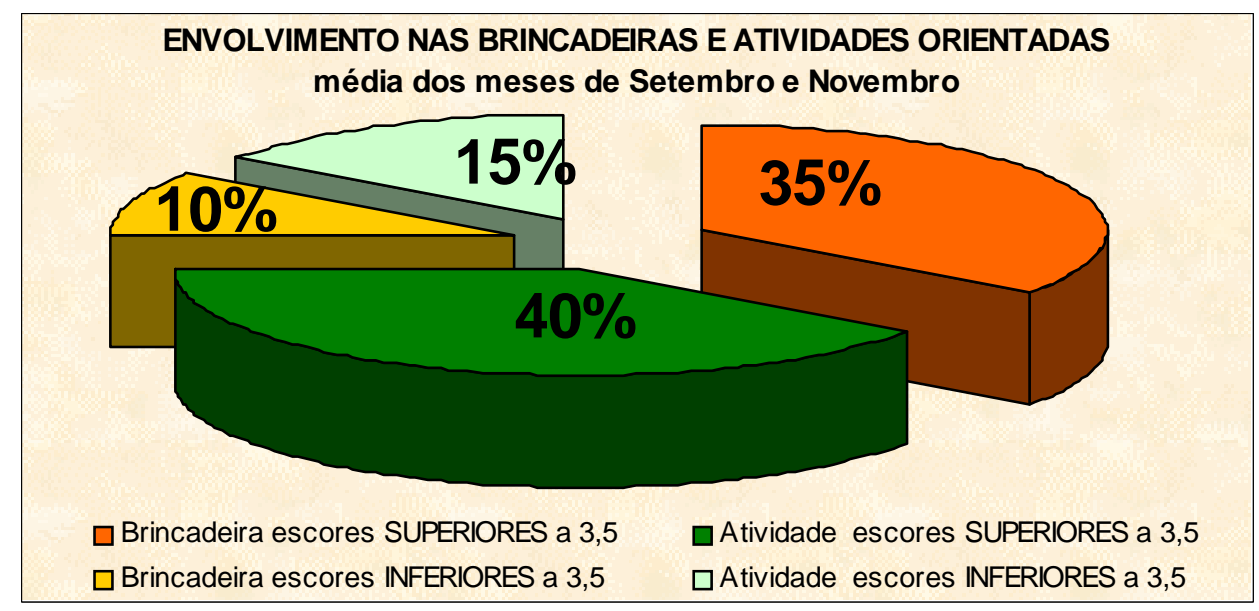

\subsubsection{Uso do computador}

$\mathrm{Na}$ classe acompanhada um dos cantos fixos é o do computador, que fica disponível às crianças durante todo o momento de trabalho reorganizado (cerca de 
1 h30 diariamente). Entre os programas disponíveis havia o editor de textos (Word), o editor de imagens/desenhos (Paint) e cerca de 40 jogos instalados quando a escola recebeu o computador como doação e teve assessoria do Instituto Avisalá ${ }^{49}$.

O uso do computador não constava como uma atividade proposta pela educadora, estando atrelado à livre escolha da criança no momento da brincadeira e às regras por ela determinadas para sua atividade. A grande variedade de ações possíveis com a escolha dos programas disponíveis, a possibilidade de interromper a ação quando desejasse, a oportunidade de escolher as regras e os parceiros e a ausência de cobranças da educadora por resultados esperados fizeram com que essa atividade fosse incluída no rol de brincadeiras por ocasião da análise do envolvimento da criança.

No decorrer do acompanhamento das atividades com as análises comparativas, notou-se que as crianças obtiveram altos escores de envolvimento nela e mantinham uma regularidade deste escore durante todo o ano.

O quadro 19 mostra que, dos vinte e dois episódios acompanhados, 90\% obtiveram escores iguais ou superiores a $\mathbf{4}$, sendo que $71 \%$ do total obteve escore 5 (nível máximo).

Gráfico 9 - Escore de envolvimento no uso do computador

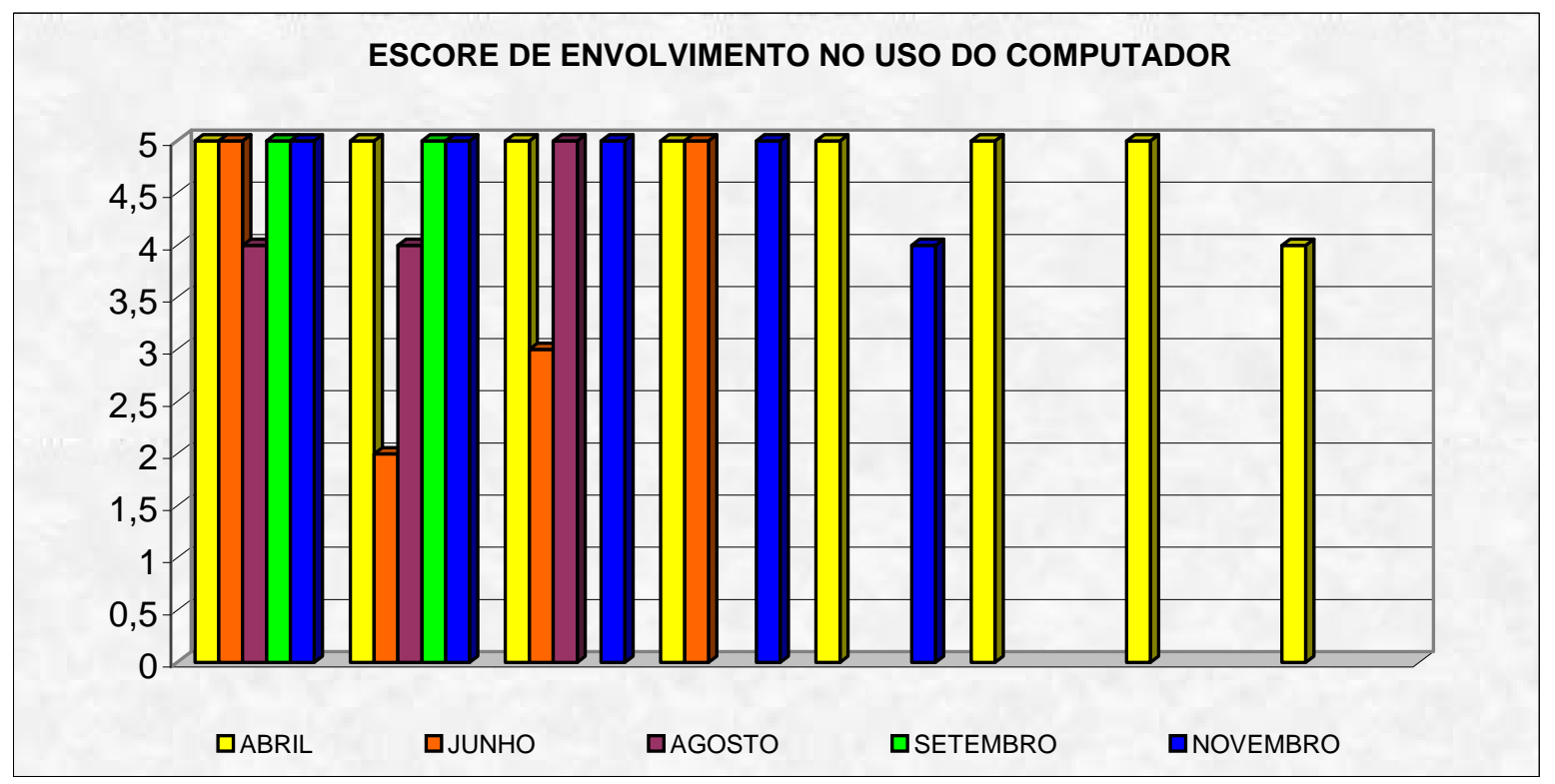

\footnotetext{
${ }^{49}$ Projeto já explicitado no capítulo 2, quando se tratou da proposta pedagógica de Reorganização dos espaços e das Atividades
} 
Dos episódios de envolvimento acompanhados, os que apresentaram a atividade da criança no uso do computador mantiveram os escores mais altos, $90 \%$ entre 4 e 5, mesmo se comparados aos escores das brincadeiras espontâneas.

Gráfico 10 - Média de envolvimento no uso do computador

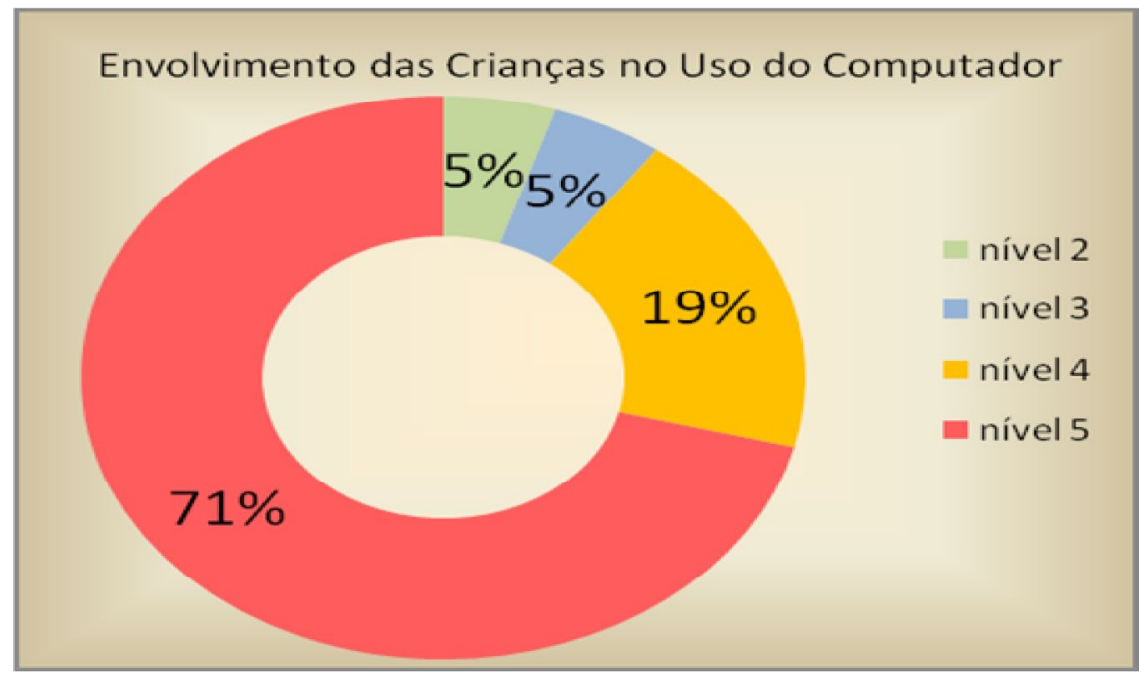

Observando a média comparativa anual podemos verificar facilmente este fato.

Gráfico 11- Comparativo anual de envolvimento por tipo de atividade

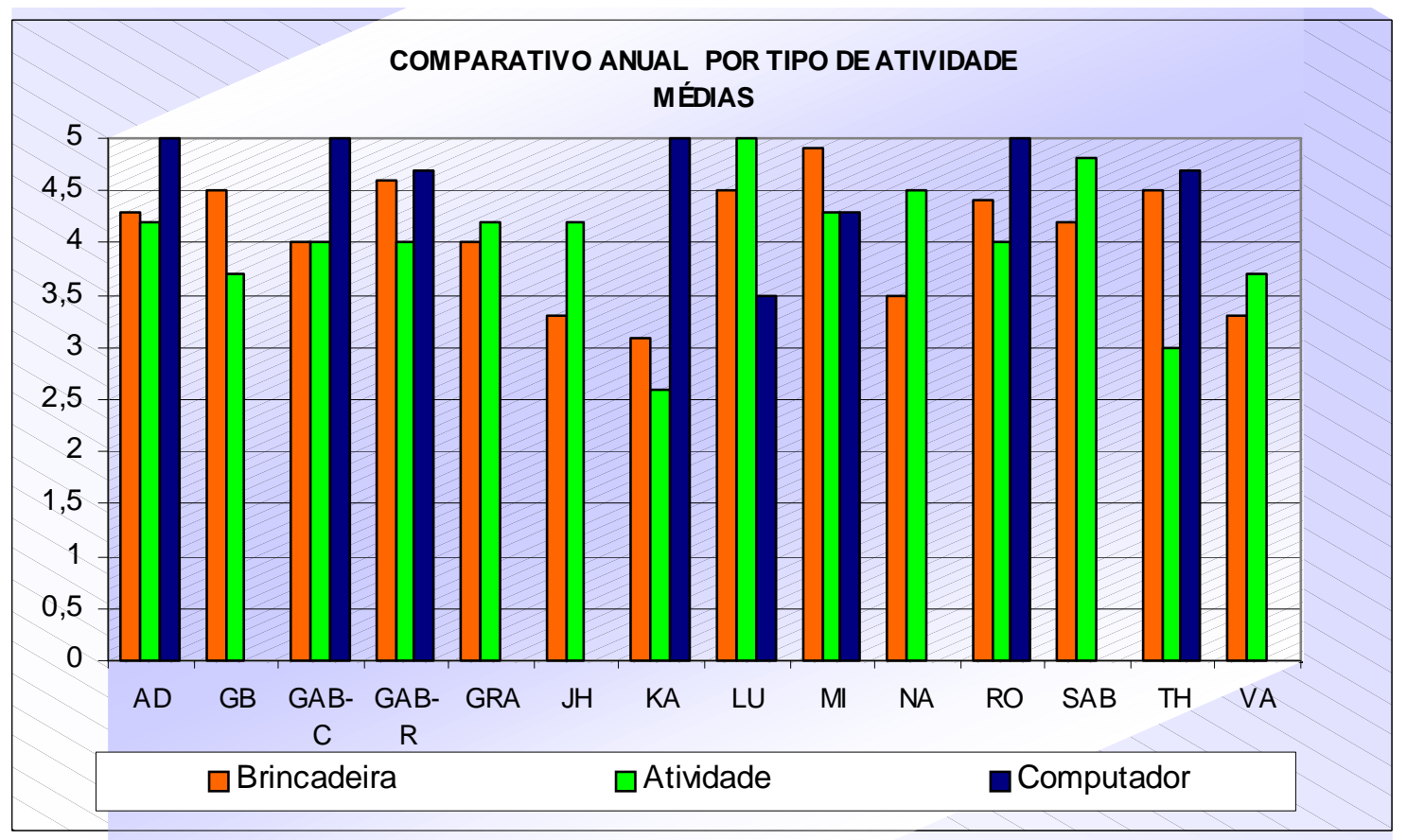


Vale ressaltar que nesta última comparação temos o escore da brincadeira retirado de todos os episódios do ano e o escore das atividades orientadas e do uso do computador concentrado apenas no segundo semestre.

Como o processo de pesquisa-ação é dinâmico e não se sabe a priori todos os rumos que a investigação irá tomar, em reunião de tutoria realizada no final de setembro de 2006 surgiu uma inquietação da educadora Luciana referente aos temas tratados e à forma como era conduzida a atividade da roda de conversa.

No mês de novembro houve uma análise especial do envolvimento da criança, voltada a sua participação na atividade de roda de conversa. Esta análise tinha objetivos formativos na medida em que serviria como base para a reavaliação da educadora sobre essa ação, como tendo qualidade aquém da que ela considerava ideal. Não houve uma análise processual deste aspecto no que tange ao envolvimento da criança e os episódios foram em número insuficiente para análise nos critérios estipulados por Laevers (1994, 2000), mas serviram de base para reflexão e optamos por colocá-los aqui, visto corroborarem análises anteriores sobre a influência do contexto educativo no envolvimento das crianças. Possibilitam também a visualização ao leitor do uso da escala de envolvimento no processo de tutoria, com objetivos de alterar a realidade que se apresentava.

Os resultados obtidos apontam que as mesmas crianças que tiveram escores altos em diferentes atividades mostraram uma regularidade de escores baixos nesta atividade específica. Isso atingia quase a totalidade das crianças, o que fez a educadora confirmar a existência de um problema na sua prática educativa no que se referia a condução da ação desenvolvida, dando partida então a um processo de observação-reflexão-ação para alterar as características da atividade, diferenciandoa da maneira como ela vinha sendo trabalhada até então.

Quanto aos dados relativos ao envolvimento das crianças na roda de conversa, tivemos os seguintes escores observados: 
Gráfico 12 - Escores médios de envolvimento na roda de conversa

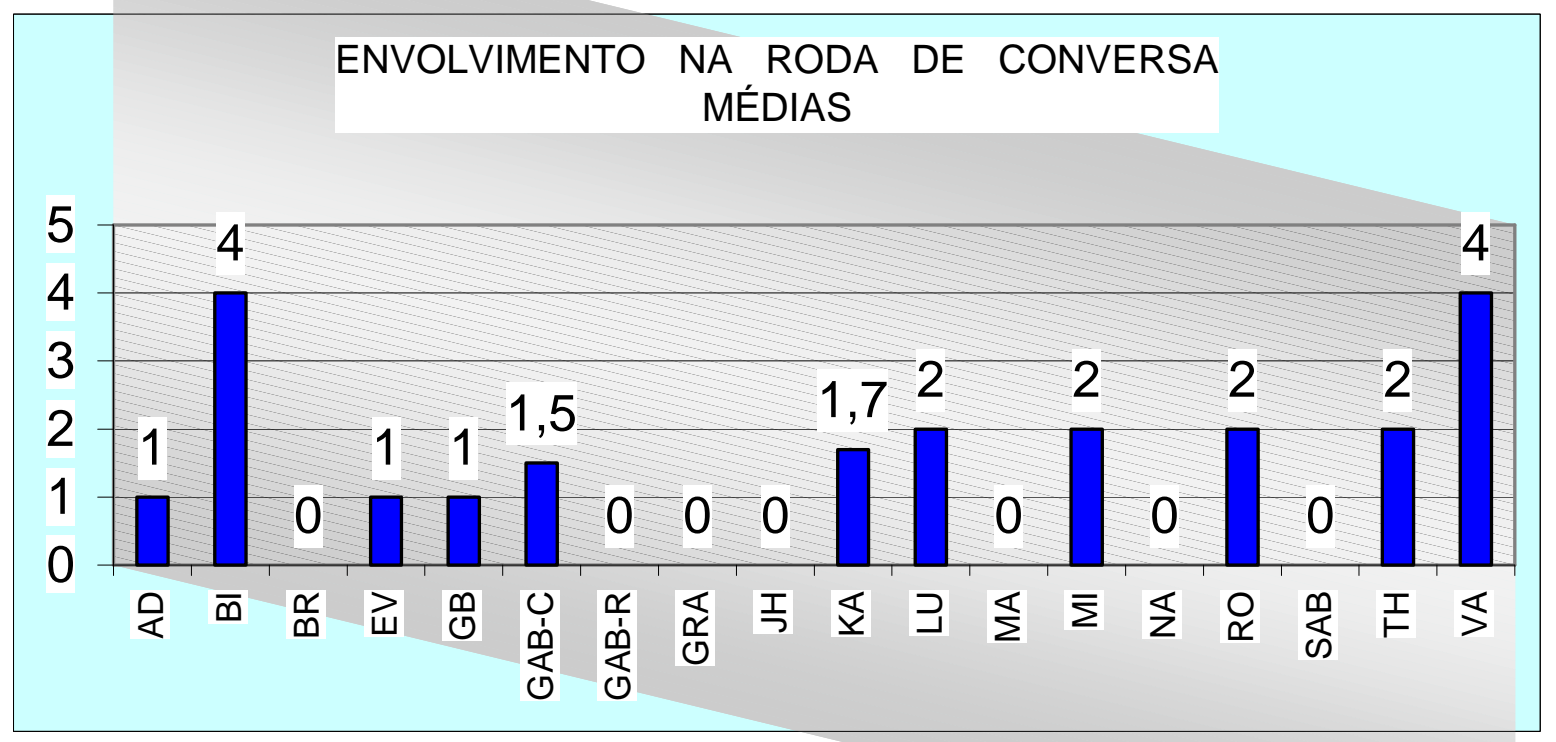

Se essa análise se reportasse apenas ao mês de novembro seria possível verificar que mesmo sendo as duas atividades propostas pela educadora, a roda de conversa teve escores significativamente mais baixos do que as atividades orientadas ficando, na maioria das vezes com escores inferiores àqueles considerados por Laevers como representativos da "entrada na qualidade" (o autor atribui o escore mínimo de 3,5).

Gráfico 13- Envolvimento nas atividades orientadas e na roda de conversa: comparativo do mês de Novembro

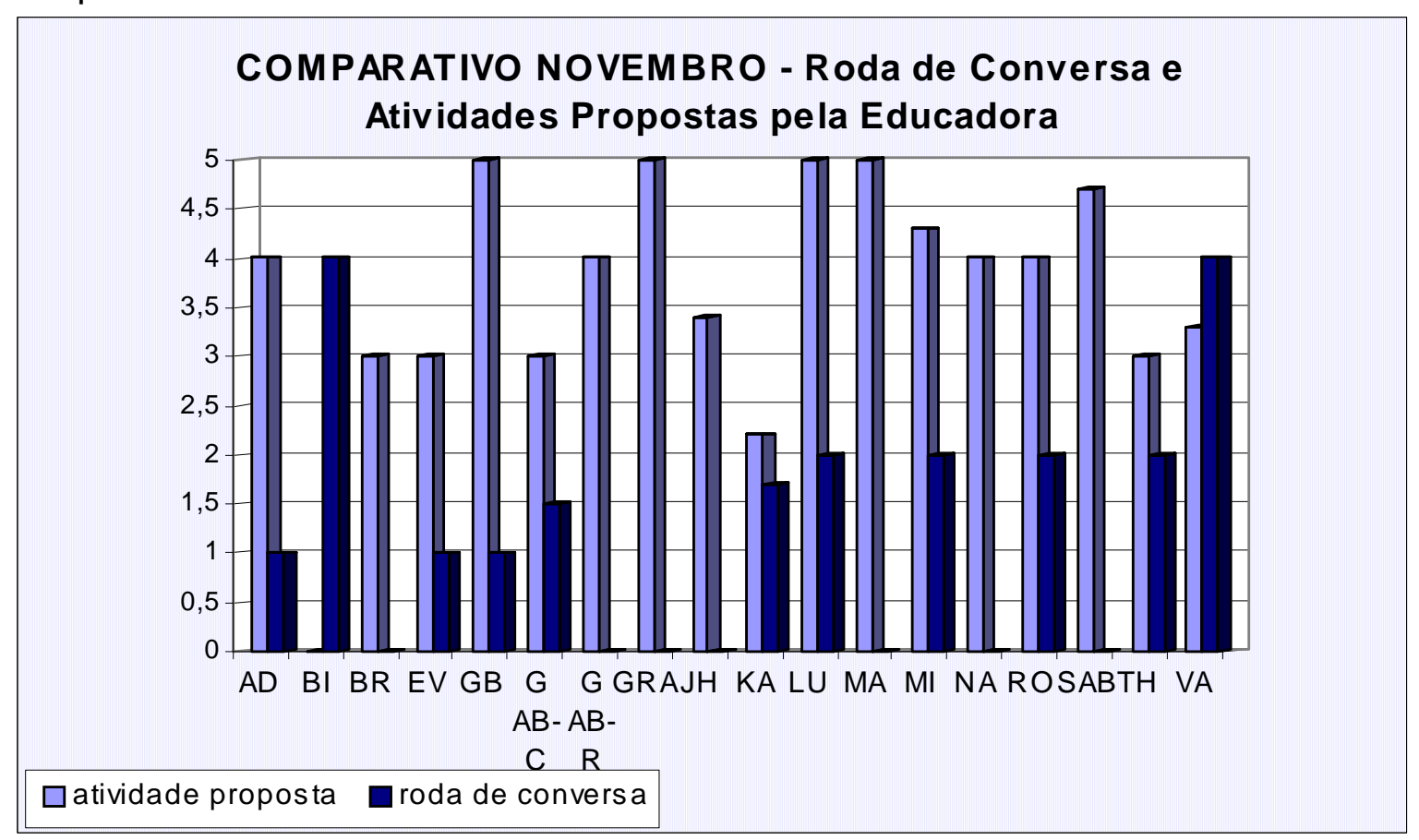


O gráfico acima dá mostras da dificuldade da educadora em fazer da atividade de roda de conversa um espaço real de participação e envolvimento da criança. As análises comparativas dos dois tipos de atividades que eram organizadas e propostas pela educadora mostram escores significativamente menores atribuídos para o envolvimento da criança nas atividades de roda de conversa.

Vale lembrar que o mês de novembro teve, nas atividades orientadas, os menores escores médio em relação a outros meses acompanhados, mas, ainda assim, estes escores suplantaram em grande medida os atribuídos às atividades de roda de conversa.

Acredita-se que nesse tipo de atividade, o contexto da sala era ainda um grande complicador, principalmente no que se refere à proporção adulto-criança e ao ambiente ruidoso, contudo isso não elimina a necessidade de mudanças com relação à atuação da educadora, que engloba desde o planejamento até a execução e avaliação da atividade junto às crianças.

Devido ao término do ano letivo não foi possível a continuidade deste processo reflexivo naquela ocasião. Parece-nos, todavia, que a perspectiva de responsabilizar-se pelos efeitos da prática pedagógica nas crianças e a crença da educadora na possibilidade de intervir em direção à qualidade da ação dão mostras efetivas dos efeitos do processo de tutoria e pesquisa compartilhada.

Concluindo as análises dos escores de envolvimento das crianças nas atividades que realizavam, pode-se notar que os dados coletados corroboram as observações da pesquisadora e da educadora realizadas em outros momentos, no que se refere ao progressivo aumento do envolvimento das crianças, particularmente quando foram feitos ajustes na prática pedagógica para respeitar desejos e necessidades das crianças. As atividades orientadas tiveram ainda, com mais clareza, os resultados dessas intervenções.

A educadora, pensando no envolvimento das crianças, acreditou que esta análise, além de útil para avaliar o contexto educativo, trouxe-lhe ganhos que se aplicam a sua ação como um todo. Diz ela:

[...] o envolvimento da sala também aumentou de certa forma. As crianças permaneciam mais tempo em determinada atividade, você não precisava ir toda hora lá, ficar prestando atenção em quem estava no computador, porque eram duas crianças que estavam no computador mas os outros 
estavam envolvidos em outras coisas e nem estavam mesmo exigindo ficar no computador.

É como se eles tivessem mesmo assim: "- Eu escolhi determinada atividade hoje e vou fazer isso." E realmente o envolvimento naquela atividade ia aumentando e parece que eles iam assim se aprofundando mais naquela atividade (algumas coisas em alguns momentos). Nem em todos observei isso, mas parece que para alguns então a brincadeira ia se tornando mais interessante, a forma de construir a casinha, por exemplo, ia ficando mais legal (Entrevista dezembro06)

Essa complexificação das atividades das crianças foi visível com o decorrer do processo e foi avaliada como uma conseqüência do aumento do envolvimento, todavia acredita-se que as causas para tal complexificação sejam várias: mudanças nos espaços e materiais, alterações nas propostas de atividades feitas pela educadora, maior número e diversificação das relações interpessoais entre as crianças, clima colaborativo da classe, entre outros. No entanto, não temos dados suficientes para atribuir a cada um destes aspectos o devido peso nessa mudança.

Esse processo de dedicação da criança à atividade que realizava, complexificando-a, pode ser notada na seqüência de fotos a seguir, onde a cada dia percebiam-se alterações nas construções realizadas, ao mesmo tempo em que as brincadeiras contavam com mais divisões de papéis.
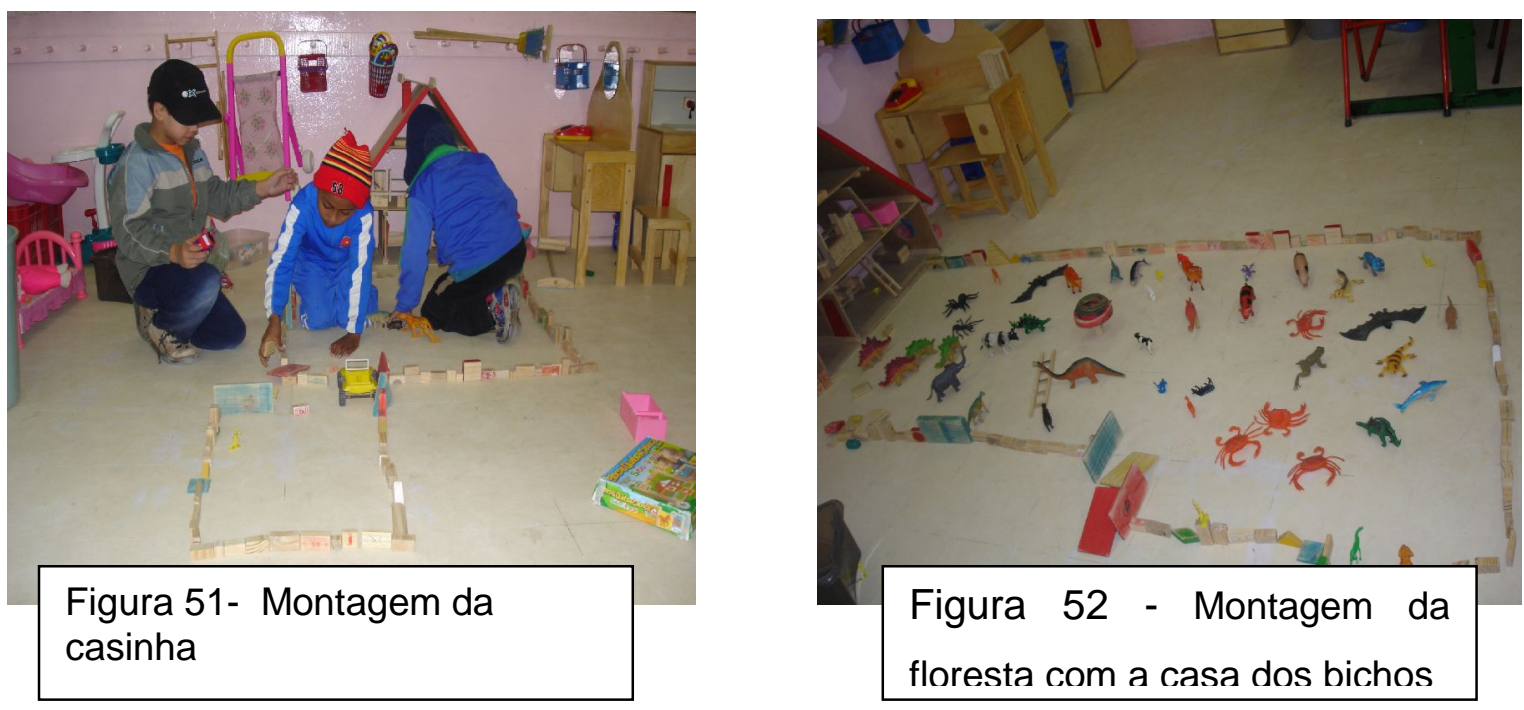

A diversidade dos arranjos de materiais ocorria nessa brincadeira que se reiniciou espontaneamente por vários dias seguidos, tomando, no entanto, diferentes caminhos, com a constante reinvenção da atividade. 
Sobre esse envolvimento, ainda há falas da educadora que corroboram efeitos como concentração, atenção, energia, persistência, satisfação. Quanto ela comenta, por exemplo, que "É como se naquele momento onde eles pudessem escolher o que gostam de fazer eles ficassem mais tranqüilos, não era naquele momento que eu precisava chamar atenção deles ou que aconteciam os problemas $^{50 "}$.

Observando o envolvimento das crianças na atividade, a análise do uso do computador e da roda de conversa trouxe dados reveladores que suscitaram novas reflexões tanto para a educadora quanto para a pesquisadora.

No caso do computador, considerando o grande foco de envolvimento que despertou, indagações sobre este fato geraram hipóteses sobre se esse interesse e envolvimento das crianças derivavam do processo de uso da máquina em si ou se estavam vinculados às atividades ali desenvolvidas. Além disso, causou grande inquietação a análise das atividades que estavam sendo propostas pelo meio digital. Serão elas pertinentes? Estarão de acordo com os princípios da pedagogia que se abraça? A inclusão digital é um bem em si mesmo ou deveria estar sujeita aos objetivos e concepções que se tem de uma educação infantil de qualidade?

Não foi possível responder esses questionamentos. Contudo, o simples fato de ter entrado em contato com essas inquietações pode suscitar a busca da construção de conhecimento nesse campo. Acredita-se que uma pesquisa precisaria ser iniciada nessa direção.

O ponto principal desta análise do envolvimento da criança foi a constatação de que os contextos educativos afetam diretamente a aprendizagem e 0 desenvolvimento da criança e que, em posse de um conhecimento mais profundo do contexto em que atua, o educador torna-se mais competente para interferir, transformando-o, e assim tornando-se um real mediador para auxiliar o processo de construção de conhecimentos da criança pequena.

\footnotetext{
${ }^{50}$ Texto extraído da entrevista realizada coma educadora Luciana em dezembro de 2006
} 


\section{CONSIDERAÇÕES FINAIS}

Como em todo estudo de caso, não é possível enunciar generalizações a partir da pesquisa-ação desenvolvida. Contudo, os resultados obtidos no processo investigativo iluminam algumas possibilidades de análise da temática em foco e, por isso, podem contribuir com futuras pesquisas.

Mediante o exame dos dados coletados, identificou-se uma expressiva mudança de postura da educadora que, como parceira da pesquisa-ação desenvolvida, demonstrou crescente capacidade de ousar, de realizar mudanças em sua ação educativa. Foram fundamentais os processos reflexivos desencadeados pela tutoria entre pares, em que se compartilharam iniciativas e inquietações.

Essa partilha que se estabeleceu entre pesquisadora e educadora, baseada num esforço de reflexão na ação e sobre a ação, proporcionou à educadora a legitimação de suas investidas em direção à transformação da prática pedagógica.

No percurso formativo experimentado neste estudo ocorreu uma alteração na cultura docente relacionada à prática pedagógica da educadora envolvida. No decorrer do tempo da pesquisa-ação e com o processo de tutoria, essa prática migra gradativamente de uma perspectiva pedagógica transmissiva para uma pedagogia da participação. A educadora toma consciência de seu papel como mediadora, sendo capaz de fornecer, em diferentes momentos, o suporte necessário às aprendizagens das crianças, respeitando suas singularidades e também seu protagonismo.

Foi possível compreender no esforço transformador revelado pela educadora a diferenciação feita por Oliveira-Formosinho, quando conceitua pedagogia transmissiva e pedagogia da participação.

A pedagogia da transmissão que se centra na lógica dos saberes, no conhecimento que se quer veicular, resolve a complexidade através da escolha unidirecional dos saberes a serem transmitidos e da delimitação do modo e dos tempos para fazer esta transmissão, tornando neutras as dimensões que contextualizam esse ato de transmitir.

[...] a pedagogia da participação centra-se nos atores que constroem o conhecimento porque participam progressivamente, através do processo educativo, da(s) cultura(s) que os constituem como seres sócio-histórico-culturais. A pedagogia da participação realiza uma dialogia constante entre a intencionalidade conhecida para $o$ ato de ensinar e a prosecução no contexto com os atores, porque estes são pensados como ativos, competentes e com direito a co-definir 0 
itinerário do projeto de apropriação da cultura que chamamos educação (Oliveira-Formosinho, 2007, pp. 17-19).

Nesse processo de transformação nota-se que há, entre os dados coletados, os que vêm confirmar que com o passar do tempo a educadora foi atribuindo cada vez mais valor às atividades da criança que envolviam brincadeiras e processos criativos. Esse efeito do trabalho formativo, construído em conjunto educadora/pesquisadora vai ao encontro dos escritos de Kishimoto (2005, p. 53) que vêm enfatizar que nas "pedagogias da infância que valorizam o interesse e as necessidades infantis, a agência como ação auto-iniciada pela criança e a partilha com protagonistas, tendem a criar maior espaço para o brincar".

A hipótese de que a implantação da proposta pedagógica adotada na unidade educacional denominada Reorganização dos Espaços e das Atividades alteraria a ação educativa, retirando-lhe o caráter escolarizante, não se confirmou por completo. Ficou claro que a mera implantação de uma nova proposta não basta para alterar as práticas sedimentadas vigentes. Os dados coletados demonstram que os elementos determinantes das alterações não emanaram das especificações contidas no interior da proposta em si. A concretização de tais mudanças esteve sempre nas mãos da educadora que encampou o desafio de atuar diferentemente, fazer valer os princípios estabelecidos e viver um processo de ação-reflexão-ação, voltado à ampliação da qualidade da prática educativa.

Notou-se que o envolvimento e, sobretudo, o investimento da educadora no processo de mudança foi gradativo e crescente. No caso do estudo realizado, embora a proposta pedagógica adotada pela unidade educacional trouxesse a perspectiva da agência e da ação da criança, a educadora inicialmente "convivia" com essa proposta, utilizando, de acordo com sua conveniência, ora essa perspectiva, ora a atividade centrada no adulto, com características de uma educação transmissiva.

Mostras dessa afirmação estão retratadas nos dados relativos ao Eixo 1 de análise, quando a educadora, ao mesmo tempo em que privilegiava o interesse e a ação autônoma da criança nas atividades relacionadas à brincadeira (que ocorria no 
espaço reorganizado), propunha atividades orientadas de cunho visivelmente escolarizante em outros momentos do dia $^{51}$.

Com o estudo empírico confirmou-se a possibilidade da tutoria entre pares como um processo formativo plausível de ser realizado com sucesso. Os avanços significativos demonstrados pela educadora ao pensar sua prática educativa revelam-se em sua capacidade de projetar novas ações a partir de realizações presentes.

No decorrer do tempo da investigação, quando se deparava com sua própria prática, a educadora foi sendo capaz de eleger os elementos que necessitavam de maior atenção e investimento, formulando hipóteses sobre as dificuldades encontradas, planejando ações para intervir na situação e avaliando os resultados.

Stenhouse (1998) corrobora a perspectiva de a pesquisa ser realizada a partir da ação desenvolvida, ao afirmar que a qualidade única de cada classe supõe que toda proposta, inclusive em nível escolar, precisa ser submetida à prova, verificada e adaptada por cada professor em sua própria classe.

Segundo o autor, o ideal é que a especificação do currículo comporte uma investigação e um programa de desenvolvimento pessoal por parte do educador, mediante o qual este aumente progressivamente a compreensão de seu próprio trabalho e aperfeiçoe assim sua capacidade de ensinar (Stenhouse, 1998).

Se o objetivo é um progressivo aumento da qualidade da educação, o educador necessita envolver-se neste processo. Ainda segundo Stenhouse (1998), investigação e desenvolvimento de um currículo devem dizer respeito ao educador e ter a perspectiva de serem levados à prática por ele. Dessa maneira os educadores que forem capazes de dominar o campo da investigação modificarão a imagem profissional que têm de si mesmos, bem como suas próprias condições de trabalho.

Contrapondo-se à própria percepção da educadora que, questionada, disse não se sentir pesquisadora, os dados obtidos demonstram que agia como pesquisadora da sua própria prática à medida que identificava problemas na ação, questionava fazeres anteriormente adotados, projetava transformações e criava condições para a efetivação de novas práticas, conseguindo, em alguns momentos, até teorizar acerca do que estava acontecendo.

\footnotetext{
${ }^{51}$ Verificar as atividades propostas pela educadora no início do ano letivo. Figuras 39 a 42 constantes do capítulo 5 - EIXO I.
} 
É fundamental apontar que a proposta de tutoria entre pares, no sentido adotado neste trabalho, necessita de parceiros abertos à aprendizagem conjunta, mas que também tenham uma condição mais avançada de exame das questões acompanhadas em processo de tutoria.

Nas unidades educacionais da Rede Municipal de Educação este par avançado deveria ser, a princípio, o coordenador pedagógico. Todavia, uma fala contundente da educadora dizia respeito ao sentimento de isolamento e de falta de apoio concreto para práticas inovadoras por parte desses profissionais nas diferentes unidades educacionais em que atuou.

A ação de Coordenadores(as) Pedagógicos(as) na Rede Municipal de Educação tem se mostrado, historicamente, mais voltada ao cumprimento de exigências burocráticas do que ao acompanhamento efetivo das práticas pedagógicas desenvolvidas.

Além dessa perspectiva de aprendizagem conjunta, os desafios se desdobram ao se pensar no papel formativo desse coordenador. Nota-se, em muitos casos, que têm sua ação pautada em concepções de criança, educação e mediação do adulto que vão ao encontro de práticas escolarizantes das quais, tanto estudiosos do campo da educação de infância, quanto os documentos oficiais de orientação curricular, pretendem distanciar-se.

Assim, para reverter essa situação de quase esterilidade da influência do coordenador pedagógico na formação continuada do educador da EMEI não basta a presença desse profissional. Faz-se necessário também formá-lo para o exercício desta função. Políticas públicas nessa direção vêm sendo criadas no município de São Paulo, mas não há dados de estudos empíricos que dêem conta do efetivo resultados desse processo formativo, mediante a detecção de impactos na prática educativa desenvolvida nas unidades educacionais.

Pensa-se que o processo de tutoria entre pares pode ser alvo de futuros estudos, verificando sua eficácia na realização desse processo formativo que envolva o coordenador pedagógico.

Os dados coletados demonstraram que alterações significativas no contexto educativo trazem um aumento do nível de envolvimento da criança na atividade.

Esse fato ficou mais visível nas atividades orientadas pela educadora quando havia maior interferência sua no contexto e nas propostas de atividades que a 
criança realizaria, mas apresentou-se também, ainda que em menor grau, nos índices de envolvimento vinculados à brincadeira.

A hipótese que inicialmente vinculava a transformação da prática da educadora ao aumento do escore de envolvimento da criança desconsiderava a complexidade do contexto educativo e a influência dos fatores a ele atrelados, dos quais, não foi possível neste estudo, precisar a interferência. É provável que a continuidade de estudos nessa direção possa iluminar outras questões de análise e, portanto, ampliar possibilidades para o estabelecimento de novas relações.

Este estudo aponta claramente para a possibilidade de intervenção no contexto educativo com vistas à melhoria da qualidade do atendimento à criança pequena, o que não significa estarem superadas questões que cabem às políticas públicas de atendimento à infância. Vários entraves são identificados na estrutura que dá suporte ao processo educativo. Entre eles vale ressaltar:

- proporção adulto criança inadequada, com média de 35 crianças para um educador;

- estrutura física e material dos prédios de educação infantil que não vão ao encontro das necessidades das crianças atendidas;

- organização burocrática do sistema, que afasta o coordenador pedagógico e o diretor da unidade educacional do acompanhamento das práticas educativas, privilegiando ações voltadas a encaminhamentos burocráticos e organizacionais;

- incompatibilidade entre as questões relativas aos direitos dos funcionários municipais e os direitos das crianças atendidas, principalmente as relacionadas às jornadas de trabalho e à possibilidade de alta rotatividade dos educadores nas unidades educacionais;

- formação continuada em serviço que, promovida pelos órgãos centrais da PMSP, apresentam-se como eventos pontuais ou, como vem ocorrendo nos últimos quatro anos, não incluem o educador no processo, considerando que o coordenador pedagógico é capaz de, sozinho, impulsionar e subsidiar o processo formativos dos educadores de sua unidade educacional;

- formação inicial dos educadores, que não comporta, no ensino superior, formação específica para o educador de infância. 
Dadas as limitações impostas pelo tempo de realização desta pesquisa, alguns questionamentos surgidos durante o processo investigativo, concernentes à temática estudada, não foram contemplados em sua totalidade. Fica o desafio de se realizarem outros trabalhos que ampliem as possibilidades de compreensão das questões suscitadas.

É de se esperar, nos processos de pesquisa-ação, que a própria pesquisadora exponha-se a uma condição de construtora de novas aprendizagens. Foi justamente o que ocorreu no desenvolvimento do processo de tutoria entre pares: existe a consciência de que muitas ações realizadas pela pesquisadora durante o estudo empírico teriam hoje nova conotação e práticas diferenciadas.

Acredita-se que novos estudos poderiam ser pensados com o intuito de responder questões como:

- o processo de tutoria entre pares, envolvendo um grupo de educadores e coordenadores pedagógicos, seria capaz de gerar avanços, passíveis de visualização, na ação efetivada junto à criança?

- os resultados do processo formativo com a educadora Luciana poderiam ser notados em termos de efeitos a longo prazo?

- podem ser identificados efeitos a longo prazo nas crianças que participaram da proposta pedagógica de Reorganização dos Espaços e das Atividades?

- na perspectiva da tutoria entre pares, o estudo comparativo do envolvimento da criança na atividade proposta pela educadora e nas atividades espontâneas seria capaz de mobilizar um processo de desconstrução de práticas escolarizantes na educação infantil?

O estudo realizado permitiu maior visibilidade à idéia de que a formação dos professores em serviço é um tema em aberto, que merece muito mais investimento. Os resultados desse estudo sugerem que a questão da formação, vinculada à prática educativa, tem relação direta com a promoção da qualidade da educação infantil desenvolvida e que pode ser observada nos resultados obtidos junto à criança, através do nível de envolvimento apresentado nas atividades que realizam.

No entanto, apesar da clareza da correlação existente entre o tipo de formação desenvolvida e a promoção da qualidade da educação efetivada, cabe desvendar quais devem ser as características norteadoras dessa formação, visto que abordar apenas aspectos teóricos tem mostrado, como resultado, educadores 
com discursos muito pertinentes e afinados com o conhecimento construído no campo, mas com práticas pobres. Ao passo que centrar a formação apenas em práticas também se apresenta ineficiente, já que não possibilita ao educador extrapolar a ação "aprendida", investindo por si mesmo em outros processos de aprimoramento do seu fazer pedagógico junto à criança.

Stenhouse (1998, p.135) vem dizer que "não basta que estudemos os trabalhos dos educadores: necessitam estudá-los eles mesmos".

O desafio que se apresenta é considerar no processo formativo dos educadores de infância o que a análise da prática é capaz de proporcionar em termos de avanço no campo reflexivo e no que a teoria pode contribuir como suporte explicativo da ação, contextualizando-a no campo do conhecimento já construído sobre o objeto de estudo. Além disso, cabe considerar qual o papel do "tutor" ou agente responsável pela formação e qual o papel do próprio educador enquanto coconstrutor do seu próprio processo formativo. 


\section{REFERÊNCIAS:}

BARDIN,L. Análise de Conteúdo. Traduzido por Luis Antonio Reto et al. Lisboa: Edições 70,1977.

BENJAMIN, W; n Reflexões sobre a Criança o Brinquedo e a Educação. Trad. Marcos Vinicius Mazzari. São Paulo: Duas Cidades/ Editora 34, 2005

BIKLEN, S.K;BOGDAN,R.C. Investigação qualitativa em educação. Uma introdução à teoria e aos métodos. Tradução de Maria João Alvarez, Sara Bahia e Telmo Mourinho Baptista. Portugal: Porto Editora, 1994

BOGDAN,R.C; BIKLEN,S.K. Investigación qualitativa em educação: uma introduçãoà teoria e aos métodos. Traduzido por Maria João alvarez, Sara Bahia dos Santos e Telmo Mourinho Baptista. Porto -Cordex-Portugal: Porto Editora,1994.

BRASIL, Conselho Nacional de EducaçãoParecer/ CEB/22/98 .Diretrizes Curriculares Nacionais para Educação Infantil. Brasília.D.F. 1998.

BRASIL,Lei o 9394 de 20/12/96. Lei de Diretrizes e Bases da Educação Nacional. Brasília D.F.Senado 1996.

BRASIL,SÃOPAULO,SÃO PAULO.Decreto Municipal ํo 40268 de 31/01/01. Integração das Creches no Sistema Municipal de Educação.

BRASIL,SÃOPAULO,SÃO PAULO.Lei Municipal n`13574 de 2003 de 13/05/03.Reestruturação das carreiras do quadro dos profissionais da educação.

BRASIL.Constituição (1988). Constituição da República Federativa do Brasil. Brasília,DF: Senado 1988.

BRASIL, Ministério da Educação. Referencial Curricular Nacional para a Educação Infantil. Brasília : MEC/ SEB. Brasília, DF, 2005

BRASIL..Estatuto da Criança e do Adolescente. Lei 8069 de 13/07/1990 Brasília,DF: Senado 1990. 
BRASIL.Resolução CEB n¹, 07/04/1999.Diretrizes Curriculares da Educação Nacional. Brasília,DF:1999

BRASIL, Parâmetros Nacionais de Qualidade para a Educação Infantil.

Ministério da Educação, Brasília,DF:2006. Documento Acessível no site do Ministério da Educação. Site: http://portal.mec.gov.br/seb/arquivos/pdf/Educinf/.

BRONFENBRENNER,U. A ecologia do desenvolvimento humano: experimentos naturais e planejados.Traduzido por Maria Adriana Veríssimo Veronese. São Paulo: Artmed editora,2002

BROUGÈRE,G. A criança e a cultura lúdica. In: KISHIMOTO,T.M(org) O brincar e suas teorias . São Paulo: Pioneira, 1998.pp19-32.

Paulo: Cortez editora ,2004

Brinquedo \&cia. Traduzido por Maria Alice A. Sampaio Doria. São . Brinquedo e cultura. Traduzido por Gisela Wajskop. São Paulo:

Cortez editora ,1994

. Jogo e educação. Traduzido por Patrícia Chittoni Ramos. São

Paulo: Artmed editora ,2003.

CAILLOIS, R. Jeux et lês Hommes: Le masque et La reúve. Paris: Gallimard, 1967 1967

CAMPOS,M.M. a Regulamentação da Educação Infantil .In : MEC/SEF/DPEF / COEDI. Subsídios para Credenciamento e Funcionamento das Instituições de Educação infantil. Brasília : MEC,1998,vll, p.35-63

CAMPOS,M.M. A Qualidade da Educação em Debate. Revista Umbral: 2000 . Acessado em 11/07 site http://dialnet.unirioja.es/servlet/oaiart?codigo=1249324

CAMPOS, M. M. M. ; FULLGRAF, Jodete Bayer G ; WIGGERS, Verena . A Qualidade da Educação Infantil Brasileira: alguns resultados de pesquisa. Cadernos de Pesquisa, Campinas/São Paulo, v. 36, n. 127, p. 87-128, 2006.

CAMPOS, M. M. M. (Org.) ; CRUZ, Silvia Helena Vieira (Org.) . Consulta sobre qualidade da Educação Infantil: o que pensam e querem os sujeitos desse direito. 1. ed. São Paulo: Cortez, 2006a. v. 1. 126 p.

CAMPOS, M. M. M. . A Formacao de Professores para Criancas de 0 a 10 anos: modelos em debate. Educação \& Sociedade, Campinas, v. XX, n. 68, p. 126-142, 1999. 
COLL,C; et al. O Construtivismo na Sala de Aula. Tradução Claudia schilling. São Paulo: Editora Atica, 2002.

; et al . O Construtivismo na Sala de Aula: novas prspectivas para a acção pedagógica. Porto: Edições Asa, 2001. In OLIVEIRA-FORMOSINHO ,J; Supervisão em educação de infância. Portugal:Universidade do Minho, instituto de Estudos da Criança, 2001

Aprendizage Escolar y Construcción del Conocimiento.

Barcelona: Ediciones Paidos, 1990. In OLIVEIRA-FORMOSINHO ,J; Supervisão em educação de infância. Portugal:Universidade do Minho, instituto de Estudos da Criança, 2001

CSIKSZENTMIHALYI,M. A Descoberta do Fluxo: a psicologia do envolvimento com a vida cotidiana.Traduzido por Pedro Ribeiro.Rio de Janeiro: Rocco Editora, 1999

A Psicologia da Felicidade. Traduzido por Denise Maria Bolanho. São Paulo: Saraiva Editora,1992

DENZIN,N y LYNCOLN,Y. Handbook of Qualitative research. Thousand Oaks.CA:Sage 1984.

DURAN,D,G;VIDAL,V. Tutoria entre Iguales. De La Tutoria a La Práctica. Barcelona: Editora Graó: 2004.

DURAN,D.G. Tutoria entre iguals .Processos Cognitivorelacionais e Anàlisi de la Interactivitat em Tutories Fixes i Recíproques. Departament de Psicologia de L'Educació. Universitat Autònoma de Barcelona,Tesi Doctoral 2002.

ELIAS,M.D.C;SANCHES, E.C. Freinet ea pedagogia- uma velha idéia muito atual. In ; KISHIMOTO,T.M;PINAZZA,M.A (orgs) Pedagogia(s) da Infância. Dialogando com o Passado. Construindo o Futuro Porto Alegre: Artmed Editora:2007, pp. 145-170.

ELKONIN, D.B. Psicologia do Jogo . Trad. Alvaro Cabral. São Paulo, Martins Fontes: 1988

ELLIOT,J. La investigación -ación en el aula. Madrid: Morata,1990. Citado por GOMEZ,G.R; FLORES,J.G ; JIMÉNEZ,E.G.Metodología de la investigación cualitativa.2.ed.Málaga-Espanha: Ediciones Algibe,1999. 
La investigación -ación en educacion . 4.ed. Madrid: Morata,2000

FARIA,A.L.G. Loris Malaguzzi e os direitos das crianças pequenas. In OLIVEIRA-FORMOSINHO;KISHIMOTO,T.M;PINAZZA,M.A (orgs) Pedagogia(s) da Infância. Dialogando com o Passado. Construindo o Futuro Porto Alegre: Artmed Editora:2007

A Contribuição dos Parques Infantis de Mario de Andrade para a Construção de uma Pedagogia da Educação Infantil. Revista educação e Sociedade, ano XX no 69. Campinas: Cedes, dezembro de1999

FINO,C.N. Vygotsky e a zona de desenvolvimento proximal: três implicações pedagógicas. In Revista Portuguesa de Educação, vol 14, n².pp273-291.Periódico on line.Braga-Portugal: La Homeroteca en linea en ciencias sociales.Publicação 2001. Acesso <http://redalyc.uaemex.mx/redalycpdf/374142.pdf >consultado em 01/02/06.

FORMAN E FORNOST. The Use of Piaget's Construtivism in early childhood education ,1982. In SPODEK,B ; BROW,P.C .Manual de Investigação em Educação de Infância. Tradução Ana Maria Chaves. Lisboa: Fundação Calouste Gubbenkian, 2002

FRANCO,M.A . Pedagogia da pesquisa-ação. In Educação e Pesquisa: revista da faculdade de educação da USP. São Paulo: vol31 ,n ³, pp483-502.set-dez 2005.

GANDINI,L ; EDWARDS,C ; FORMAN,G. As cem linguagens da criança:a abordagem Reggio Emilia na educação da primeira infância.Traduzido por Dayse Batista.Porto Alegre: Artmed Editora ,1999.

GARMSTON,R.J;LIPTON,L.E;KAISER,K. A Psicologia da Supervisão. In OLIVEIRA-FORMOSINHO Supervisão na Formação de Professores II. Da organização à Pessoa. Traduzido por Sara Barros Araújo. Porto; Porto Editora,2002

GARMSTON,R; WELMAN,B. Adaptive scools in a quantum universe. Educacional Leardship 52 (7),1995 In GARMSTON,R.J;LIPTON,L.E;KAISER,K. A Psicologia da Supervisão. In OLIVEIRA-FORMOSINHO Supervisão na Formação de Professores II. Da organização à Pessoa. Traduzido por Sara Barros Araújo. Porto; Porto Editora,2002

GOMEZ,G.R; FLORES,J.G ; JIMÉNEZ,E.G. Metodología de la Investigación cualitativa.2.ed.Málaga-Espanha: Ediciones Algibe,1999. 
JOHNSON,D;JOHNSON,R;HOLUBEC,E. El Aprendizae Cooperativo in el Aula. Barcelona: Paidòs Educador .Citado por DURAN,D.G. Tutoria entre iguals .Processos Cognitivorelacionais e Anàlisi de la Interactivitat em Tutories Fixes i Recíproques. Departament de Psicologia de L'Educació. Universitat Autònoma de Barcelona,Tesi Doctoral 2002.( pag 51)

KISHIMOTO,T.M. O jogo e a educação infantil In: (org) Jogo, brinquedo,brincadeira e a educação. 7.ed.São Paulo: Cortez editora, 2003. pp13-43.

A Pré - Escola em São Paulo : das origens a 1940. Tese de Doutoramento apresentada à Faculdade de Educação da Universidade de São Paulo, 1986. In PINAZZA,M.A; A Pré-Escola Paulista à Luz das Idéias de Pestalozzi e Froebel: memória reconstruída a partir de periódicos oficiais. São Paulo. Faculdade de educação da universidade de São Paulo, 1997

Cortez editora, 1996

. (org) Jogo, Brinquedo, Brincadeira e a Educação.7ed. São Paulo:

. O jogo e a educação infantil. In:PIACENTINI (org) Revista

Perspectiva : A modernidade, a infância e o brincar.Florianópolis: Editora da UFSC.ano 12 n2․ 2 pp105-128.2ํㅗemestre 1994.

A LDB e as instituições de Educação Infantil:desafios e perspectivas.n In: Revista paulista de Educação Física,periódico on line, suplemento 4,pp7-14. Publicado em 2001.Acesso:

$<$ http://www.usp.br/eef/rpef/supl42001/v15sp7.pdf>.Consultado em 20/01/06

.Recuperando a história da educação infantil em São Paulo. In:

Revista escola Municipal: 50 anos de pré-escola municipal. São Paulo: Secretaria Municipal da educação,ano 18 ํo13.1985,pp.6-10.

.Salas de aula de escolas infantis: domínio da fila ,tempo de espera e falta de autonomia da criança.In: Revista Nuances. São Paulo,vol 5,pp.1-6,julho 1999.

Encontros e Desencontros na Formação dos Profissionais de Educação Infantil. In MACHADO, M.L.de A (org) Encontros e Desencontros na Educação Infantil. São Paulo: Cortez editora,2002 , In OLIVEIRA-FORMOSINHO ,J ; KISHIMOTO,T.(orgs)Formação em Contexto. Uma estratégia de Integração. São Paulo: Thomson 2002. 
.O Sentido da Profissionalidade para o Educador de Infância. In BARBOSA, R.L.L(org);Trajetórias e perspectivas da Formação de Educadores São Paulo: Editora UNESP , 2004 pp.329-345

. O brincar e a Linguagem. In FARIA, A.L.G; MELLO,S.A (orgs) Mundo da Escrita no Universo da Pequena Infância. Campinas: Autores associados, 2005 pp 51-74.

KRAMER,S. O Papel Social da educação infantil. In A política pré-escolar no Brasil: a arte do disfarce.6.ed.São Paulo, Cortez editora, 1992.Disponível no site www.dc.mre.gov.br/brasil/textos/revista7-mat8.pdf

KRAMER, S. Crianças de $\mathbf{0}$ a $\mathbf{6}$ anos nas Políticas Educacionais do Brasil: Educação Infantil e/ é Fundamental . Revista educação e Sociedade. Campinas, vol 27 no 96. Outubro de 2006 pp 797-818. disponível em http://www.cedes.unicamp.br

Professoras de Educação infantil e Mudança. Reflexões a partir de Bakhtin. In Cadernos de Pesquisa da Fundação Carlos Chagas. V 34 nำ 122. São Paulo: Editora Autores associados, Maio-agosto 2004, p.497-515

KUHLMANN JUNIOR,M. Educando a Infância Brasileira In: LOPES,E.M.T;FARIA FILHO,L.M;VEIGA,C. $\mathbf{5 0 0}$ anos de educação no Brasil. 2.ed.Belo Horizonte: Autêntica, 2002 pp.469-496.

LAEVERS,F. L'education expérientielle: I' implication de l' enfant, un critére de qualité. In: RAYNA Sylvie ; BROUGÈRE, G (coord.)Traditions et inovations dans l'education préscolaire:perspectives internationales. Paris: Institut Nacional de Recherche Pédagogique,2000, pp 293-322.

The Leuven Involvement Scale for Young Children-LIS-YC:

manual and video tape, Experimental Education Series. Editora Leuven.Centre for Experimental Education, $1994 \mathrm{~A}$.

The Innovatine project Experiential: Education and the definition of quality in Education In ,Defining and assessing quality in early childhood education pp.159-172 Leuven:Leuven University Press. Citado por OLIVEIRAFORMOSINHO,J.O (org)Modelos Curriculares para a Educação de Infância. 2.ed.Porto-Cordex-Portugal:Porto editora,1998 . RAYNA,S;DELEAU,M. L’Éducation Préscolaire. Quels Objectifs Pédagogiques? Nathan Pédagogie, 1996. 
LEONTIEV, A . N. Os princípios psicológicos da brinacadeira pré- escolar In: VIGOTSKI,L.S ;LURIA, A . R; LEONTIEV, A . N. Linguagem , desenvolvimento e aprendizagem. Traduzido por Maria da |Penha Villalobos.8.ed. São Paulo:Ícone 2003.Cap 7 pp.119-142

LINO,D. O modelo curricular para a educação de infância de Reggio Emilia: uma apresentação . In: OLIVEIRA-FORMOSINHO,J. (org)Modelos Curriculares para a Educação de Infância. 2.ed.Porto-Cordex-Portugal:Porto editora,1998.Cap III pp.93-136.

MALGLAIVE, G. Ensinar Adultos. Traduzido por Maria Luiza A. Pereira, Manoel António de Oliveira e Silva e Maria M Martinho Ferreira. Portuga: Porto Editora, 1995.

MELERO,M.A;FERNANDEZ,P. El Aprendizaje Entre Iguales: El Estado de la Cuestionen Estados Unidos" In (idem) La Interacciòn Social em Contextos Educativos. Madrid; Ed S. XXI. Citado por DURAN,D.G. Tutoria entre Iguals .Processos Cognitivorelacionais e Anàlisi de la Interactivitat em Tutories Fixes i Recíproques. Departament de Psicologia de L'Educació. Universitat Autònoma de Barcelona,Tesi Doctoral 2002 (pag 66)

MELERO, M.A; FERNADEZ,P. El aprendizaje entre iguales: El estado de la cuentiòn en Estados Unidos . In FERNADEZ,P; MELERO, M.A (orgs) La interacición social en contextos educativos. Madrid: Editora Sec XXI, 1995

MIQUEL,E;DURAN,D.Tutoria entre iguals.um métode d'aprenetalge cooperatiu per la diversidade. De la teoria a la práctica. Barcelona: Publicaiones de l'ICE de LA UAB, 2003.

MIQUEL,E;DURAN,D. Cooperar para enseñar y aprender.Cuadernos de Pedagogia.no331 (p.73-76). Barcelona, 2003

; DURAN,D ; et all. Tutoria entre iguals.Um mètode d'aprenentalge cooperati per la diversidade. De la teoria a la pràctica. Barcelona: Publicaciones de l'Ice de La Vab

MOSS,P; DAHLBERG,G; PENCE,A. Qualidade na Educação da Primeira Infância: perspectivas pós-modernas. Tradução : Magda frança Lopes. Porto Alegre: Artmed editora, 2003. 
MOURA, M.O. Pesquisa Colaborativa: um foco na ação formadora. In In BARBOSA, R.L.L(org);Trajetórias e perspectivas da Formação de Educadores São Paulo: Editora UNESP , 2004 pp. 257-284

OLIVEIRA, M.K. Três perguntas a Vygotskianos, Wallonianos e Piagetianos .In LA TAILLE,I. OLIVEIRA,M.K. DANTAS,H. Piaget Vygotsky Wallon:teorías psicogenéticas em discussão.15.ed. São Paulo: Summus Editorial, 1992.pp101-115.

; DANTAS,H. Piaget Vygotsky Wallon:teorías psicogenéticas em discussão.15.ed. São Paulo: Summus Editorial, 1992.pp.75-84

OLIVEIRA,M.K. Vygotsky aprendizado e desenvolvimento:um processo sóciohistórico.São Paulo: Scipione,2001.

. O problema da afetividade em Vygotsky In: LA TAILLE,I; LA TAILLE,I. OLIVEIRA,M.K. DANTAS,H. Piaget Vygotsky Wallon:teorías psicogenéticas em discussão.15.ed. São Paulo: Summus Editorial, 1992.pp 23-34

Vygotsky e o processo de formação de conceitos. In: LA TAILLE,I. OLIVEIRA,M.K. DANTAS,H. Piaget Vygotsky Wallon:teorías psicogenéticas em discussão.15.ed. São Paulo: Summus Editorial, 1992.pp 23-34

OLIVEIRA,Z.M.R. Dos Parques Infantis àsEescolas Municipais de Educação Infantil: um caminho de $\mathbf{5 0}$ anos. In: Revista escola Municipal: 50 anos de préescola municipal. São Paulo: Secretaria Municipal da educação,ano 18 ํo13.1985 ,pp.11-18.

OLIVEIRA-FORMOSINHO, $\mathrm{J}$; et al.Associação Criança um contexto de formação em contexto .Braga-Portugal: Livraria Minho, 2002 a .

Supervisão na Formação de Professores. Da sala à escola. 1ำ volume Portugal: Porto Editora, $2002 \mathrm{~b}$

Supervisão na Formação de Professores II . Da organização à pessoa. $2^{\circ}$ volume Portugal: Porto Editora, $2002 \mathrm{C}$

OLIVEIRA-FORMOSINHO , J KISHIMOTO,T.(orgs)Formação em Contexto. Uma estratégia de Integração. São Paulo: Thomson 2002 d.

Modelos Curriculares para a Educação de Infância.

2.ed.Porto-Cordex-Portugal:Porto editora, 1998 
. Supervisão em educação de infância. Portugal:Universidade do Minho, instituto de Estudos da Criança, 2001

.(org), A contextualização do modelo curricular High - Scope no âmbito do Projecto Infância In: __ Modelos Curriculares para a Educação de Infância. 2.ed.Porto-Cordex-Portugal:Porto editora,1998 . Cap II pp.51-92

. Desenvolvendo a Qualidade em Parcerias. Nove Estudos de

Caso. Portugal:Porto editora, 1996

. BARROS.S O envolvimento da criança na aprendizagem:

construindo o direito de participação.In Revista Análise Psicológica, Periódico on line , vol 22,no 1,pp81-93 .Lisboa-Portugal : publicado 2004 .acesso:

$<$ http://www.scielo.oces.mctes.pt/pdf/ aps/n22n1/v22n1a09.pdf >consultado em 01/02/06.

. KISHIMOTO,T.M;PINAZZA,M.A (orgs) Pedagogia(s) da Infância. Dialogando com o Passado. Construindo o Futuro Porto Alegre: Artmed Editora:2007

ONRUBIA,J. Ensinar: criar zonas de desenvolvimento proximal e nelas intervir . In: COLL, $C$ et al. Construtivismo na sala de aula.Traduzido por Claudia Schilling.6.ed. São Paulo: Atica,2002.pp 123-152.

ONU.Declaração Universal dos direitos da criança. Organização das Nações Unidas 20/11/59.

PASCAL,C;BERTRAM,T. Desenvolvendo a qualidade em parcerias: nove estudos de caso. Porto Portugal: Porto Editora,1999

PASCAL , C; et al . Evaluating and Developing qualiyty in early childhood settings. Worcester: Worcester College of Higher Education IN OLIVEIRAFORMOSINHO, J;KISHIMOTO,T.M. (orgs) Formação em Contexto. Uma estratégia de Integração. São Paulo: Thomson,2002

PERRENOUD,P. A P'ratica Reflexiva no Ofício de Professor: profissionalização e razão pedagógica. São Paulo; Artmed Editora , 2002.

PINAZZA,M.A .Os pensamentos de Pestalozzi e Froebel nos primórdios da préescola oficial paulista: das inspirações originais não escolarizantes à concretização de práticas escolarizantes.In: FARIA,A.L.G; MELLO,S.A. (org).Linguagens infantis:outras formas de leitura. Campinas: autores associados,2005. Pp 85-100. 
A Pré-Escola Paulista à Luz das Idéias de Pestalozzi e Froebel: memória reconstruída a partir de periódicos oficiais. São Paulo. Faculdade de educação da universidade de São Paulo, 1997

A Educação Infantil em suas Especificidades. In: Corinta Maria Grisolia Geraldi; Cláudia Rosa Riolfi \& Maria de Fátima Garcia. (Org.). Escola Viva. 1 ed. Campinas: Mercado de Letras, 2004, v. , p. 371-385.

REGO,T.C. Memórias da escola: cultura escolar e constituição de singularidades. Petrópolis:Vozes,2003.

. Vygotsky uma perspectiva histórico-cultural da educação.16ed.

Petrópolis:Vozes,2004

ROSSETTI-FERREIRA;AMORIM,K.S;SILVA,A.P.S. Rede de Significações: alguns conceitos básicos. In: ROSSETTI-FERREIRA et al (org ) Rede de significações e o estudo do desenvolvimento humano.São Paulo: Artemed editora,2004

SACRISTÁN, J.G. A Educação que Ainda é Possível: ensaios sobre uma cultura para a educação. Traduzido por Valério Campos. Porto Alegre: Artmed editora,2007

SÃO PAULO, Secretaria Municipal da educação. Tempos e Espaços para a Infância e suas Linguagens nos CEls,Creches e EMEls da Cidade de São Paulo. São Paulo: SME,2006.

SPODEK,B ; BROW,P.C .Alternativas curriculares na educação de infância:uma perspectiva histórica. In :OLIVEIRA-FORMOSINHO,J. (org)Modelos Curriculares para a Educação de Infância. 2.ed.Porto-Cordex-Portugal:Porto editora,1998.cap I pp13-50.

Manual de Investigação em Educação de Infância. Tradução Ana Maria Chaves. Lisboa: Fundação Calouste Gubbenkian, 2002

STAKE,R.E. Investigación com estudio de casos. 2.ed. Madrid: Ediciones Morata,S.L.,1999.

STENHOUSE,L. La Investigación como base de la ensenanza. Traduzido por Guilhermo Solana. 4.Ed.Madrid: Editora Morata, 1998. 
THIOLLENT,M. Metodologia da pesquisa-ação.13.ed.São Paulo:Cortez editora.2004.

TOPPIND,K;EHLY,S. Peer Assited Learning: Lawrend E.Associates. Citado por DURAN,D.G. Tutoria entre iguals .Processos Cognitivorelacionais e Anàlisi de la Interactivitat em Tutories Fixes i Recíproques. Departament de Psicologia de L'Educació. Universitat Autònoma de Barcelona,Tesi Doctoral 2002.

TRIPP,D.Pesquisa-ação:uma introdução metodológica. In Educação e Pesquisa: revista da faculdade de educação da USP. São Paulo: vol31 ,n ${ }^{\circ} 3$, pp443-466.setdez 2005.

VIGOTSKI,L.S Aprendizagem e desenvolvimento na idade escolar In: VIGOTSKI,L.S ;LURIA, A . R; LEONTIEV, A . N. Linguagem, desenvolvimento e aprendizagem. Traduzido por Maria da |Penha Villalobos.8.ed. São Paulo:Ícone 2003 A.Cap 7 pp.119-142.

Psicologia pedagógica. Traduzido por Claudia Schilling.São Paulo: Artemed editora, 2003 B.

A formação social da mente. Traduzido por José Cipolla Neto et al. São Paulo: Martins Fontes,2000.

Obras escogidas. Traduzido por José Maria Bravo. Madrid: Centro de Publicaciones del M.E.C, 1991

WAJSKOP,G. Brincar na Pré-Escola.5.ed. São Paulo: Cortez editora,1995

WEIKART,D.P; HOHLMANN,M. Educar a Criança. Tradução de Helena A Marujo e Luis Miguel Neto. Lisboa: Fundação Calouste Gulbenkian,2004

WINNICOTT,D.W. O Brincar e a Realidade. Traduzido por José Octávio de A Abreu. Rio de Janeiro: Imago editora, 1995.

YIN,R.K. Estudo de caso: planejamento e métodos.Traduzido por Daniel Grassi.3.ed.São Paulo: Bookman,2005

ZABALA, A. Enfoque Globalizador e Pensamento Complexo. Traduzido por Ernani Rosa. Porto Alegre: Artmed editora, 2002 


\section{ANEXO A - TRANSCRIÇÃO DA ENTREVISTA DE 12/02/06}

Presentes: Meire Festa - pesquisadora (interlocutor 1)

Luciana - educadora- (interlocutor 2)

Local: EMEI Eurípedes Simões de Paula

Especificidades da entrevista: foi realizada na sala da professora Luciana, após seus primeiros contatos com o material (brinquedos, espaço, etc..) disponibilizado para a proposta de reorganização .

A entrevista teve duração de 50 minutos e teve como temas principais as primeiras impressões da professora sobre o espaço e os materiais e quais suas primeiras eleições quanto a disponibilização desses as crianças e a forma como faria isso.

\section{Transcrição:}

São Paulo 12/06/2006, entrevista com a professora Luciana sobre o repertório de brinquedos.

O nosso propósito aqui é ver que tipo de experiências com o manuseio de brinquedos você queria oferecer a eles, então você deu uma olhada nos brinquedos que estão disponíveis e, o que você achou? eu achei q tem uma quantidade muito grande de brinquedos, uma variedade também muito grande, fiquei como eu já tinha dito pra você surpresa com a quantidade de brinquedos q você tem mas, a principio o q eu tinha pensado para a sala, eu sabia que era um espaço reorganizado né, mas eu tinha pensado nos brinquedos que eu usava no dia a dia, mas a partir do momento em que eu vi tantas coisas eu tive outras idéias até. então como você tinha pensado inicialmente? eu pensei assim em jogos como quebra-cabeças, jogo da memória, eu achei que ia Ter uma variedade grande desses jogos, dominó, jogos desse tipo. Jogos simbólicos também eu já tinha pensado um pouquinho, algumas coisas q favorecessem também a brincadeira simbólica da criança e acho que só. Mas assim , eu não tinha muita 
idéia do que era, eu acho que quando eu cheguei aqui e comecei a ver as coisas q eu comecei a Ter idéias de como seria.

como foram essas idéias? o que que você colocaria ou não?

A princípio assim, pela quantidade de brinquedos eu fiquei pensando assim que se a criança tiver todos esses brinquedos disponíveis ele até se perde um pouco né, eu pensei em apresentar aos poucos esses brinquedos para q também favorecesse uma brincadeira assim, pra que eles conhecessem esse material.

O manuseio inicial?

Isso, eu tinha pensado assim. Por exemplo aquela caixa de remédios por exemplo, será que as crianças sabem o que são? Como que é essa brincadeira? Talvez até brincar junto com eles seria interessante pra favorecer algumas coisas.

Mas assim, eu acho que só começando mesmo é que eu vou Ter mais idéia do que é o espaço reorganizado e também do que eu vou precisando.

Não sei, acho que é isso.

e assim, em termos da oferta que a sala dispunha, então você falou olha: "eu vim pensando que teriam mais jogos voltados, ligados a algum tipo de conteúdo, então por exemplo para desenvolver a memória no jogo da memória isso

e tem um outro tipo de material além disso, ou um volume pequeno desses e um volume maior dos outros. Então, desses disponíveis o que você acha que seria interessante nesse momento manter, nesse momento inicial. Porque você está falando "olha eu vou então reduzir um pouco a oferta pra entrar com ele na questão do manuseio"

A princípio o que você gostaria que fosse deixado aqui pra você estar utilizando?

2 eu acho que poderia deixar algumas coisas relacionadas ao jogo simbólico mesmo, não sei até se tivesse um espelho que seria interessante né na sala, pra algumas brincadeiras também. Porque eu vi que tem algumas coisas até de cabelereiro ( acho que seria interessante) 
Que mais?

teria alguns dos disponíveis que você excluiria num primeiro momento? Quais?

Não sei porque eu não consegui mexer em tudo ainda, não consegui ver tudo ainda, mas eu acho assim que tem uma quantidade muito grande de cada, se talvez diminuísse um pouco a quantidade .

você acha que essa diminuição é de tipos de brinquedo ou quantidade de brinquedo por exemplo, deixe-me ser mais clara.

Eu acho que é a quantidade de tipos mesmo eu entendi

É a quantidade de tipos, não o volume. É o volume de brinquedos e não a variedade?

É, isso mesmo

manteria a variedade.

Eu acho que daí eles conseguem se organizar melhor, brincar melhor, quando tem uma quantidade. Não uma quantidade pequena mas assim razoável para uma brincadeira, acho que é isso.

e quando você olhou esse espaços sem mesas assim, como é que foi essa...a partir momento que você olhou e falou: eu sou a dona desse espaço agora.

Eu gostei bastante mas estou um pouco receosa também, porque eu acho q vocês já tem um trabalho ai sendo desenvolvido a bastante tempo né, e vocês pareceram assim muito envolvidas com o q fazem assim, dedicadas com o q fazem .E não sei, acho que vou usar vocês assim de modelo. To querendo usar vocês de modelo, como referência porque eu fiquei.

Eu já passei por bastante escolas assim, eu gosto de conhecer mas a gente não vê muitas pessoas dedicadas e com um proposta nova né, eu achei muito legal mas me causou assim um certo receio até.

Eu estou ainda um pouco receosa, mas não em relação..eu to em relação ao q eu vou devolver pra você, eu acho que com as crianças eu acho q não .

Como você acha q vai ser a receptividade, já q você falou então das crianças. Como você acha $q$ vai ser a receptividade das crianças pra essa proposta? 
Eu acho que eles vão adora, eu acho que eles vão gostar muito , bastante e eu também vou gostar eu acho, de trabalhar assim.

Você sabe que eu fiquei ouvindo assim um pouquinho de cada um que já trabalhou e eu ouvi assim tanto coisas boas né quanto algumas assim que não gostaram muito da proposta, que acham que não se encaixam né, mas não sei, eu tenho impressão assim que eu vou gostar bastante de trabalhar.

Mas eu to um pouco ainda, em relação ao grupo, eu to um pouco receosa.

mas ao grupo de pessoas que a proposta em si?

É eu acho que sim porque vocês já estão assim a bastante tempo, vocês se dedicam bastante a isso .

vamos ver o que é que dá, eu sinceramente acho que o novo sempre dá pra nós uma sensação de desajuste, boa. Boa né, mas é de desajuste, são pessoas novas.

Eu acho que eu estava acomodada né, também há bastante tempo também.

eu acho q você vai Ter uma receptividade muito boa e está relacionada com aquela história de que esse grupo tem muita clareza de que não existem respostas prontas, de que não tem uma resposta única, uma pílula mágica de fórmulas que vão dar certo pra todos os professores ou pra todas as crianças.

E daí, dentro disso, assim tem o respeito pela diversidade, eu acho né, vamos ver se essa sensação. E se não for eu acho legal você falar olha eu to me sentindo mal ou acuada.

Você tem a plena liberdade, com todas nós.

e pra mim é assim um grande desafio porque assim eu já to me sentindo mal de estar gravando, filmar eu vou me sentir assim super mal mas pra mim também é um desafio, eu quero, eu acho q vai ser legal assim.

e sabe que a escola tem uma proposta de filmagem, não especificamente para a reorganização, a escola (particularmente o primeiro turno) e algumas pessoas do segundo tinham o ano passado a proposta de filmagem para que o professor pudesse rever a prática 
junto com seu grupo de parceiros adultos né, pra poder refletir sobre um determinado acontecimento.

Então a proposta seria de que se acompanhasse uma prática então, por exemplo eu estou dando aula e minha amiga está no horário de parque. Alguém estaria com os alunos dela no parque e ela iria filmar na minha sala e depois em JEI essa atividade que eu dei naquele dia ia ser discutida com todo mundo pra ver os avanços, as dificuldades, pra ver as crianças né. È uma proposta da escola assim de uma maneira geral, uma coisa enquanto sugestão.

mas acho que tudo quem assim contribuir para a prática eu estou aberta, pra mim vai ser um desafio mas acho que era isso que eu estava procurando quando eu vim pra cá, acho que era essa a intenção mesmo. você foi corajosa, porque tinha gente que já estava aqui e não tinha essa coragem mesmo estando, então foi um ato de coragem seu, enfrentar o novo. (risoss) não e o fato de Ter alguém assim perto foi o que mais me atraiu. A proposta eu gostei bastante mas Ter alguém que vai acompanhar, que vai sei lá conversar a respeito da sua sala, eu achei mais interessante.

a proposta desses nossos encontros e tal, é como eu te falei tem a questão da pesquisa relativa a reorganização e o que que isso dá de efeito direto nas crianças, então eu ainda to optando por algumas questões (se vai ser a questão de envolvimento, se vai ser a questão de aumentar a interação)

isso quando tiver mais definido eu até vou estar passando pra você qual é o objetivo definido disso, mas o objetivo dessa parceria é a troca mesmo, não é a vigilância, a observação.

2 não eu não pensei por ai não tem essa característica mesmo Não eu não pensei por ai, porque senão ... legal que assim ficou claro desde o princípio hum hum 
é uma construção, da gente enquanto educador a gente está sempre construindo.

$\mathrm{Na}$ rede a gente se sente muito sozinho as vezes, mesmo as vezes quando tem o coordenador a gente se sente sozinha, parece q tem medo de chegar, não sei o que acontece.

Não sei o que acontece mas a gente se sente muito sozinho tomara assim o grupo possa, né ser mais coeso porque quanto mais coeso o grupo está os desafios aumentam, alem do apoio os desafios que cada um já tem, o apoio do outro, a solução que o outro encontrou, a solução que o outro dá acaba clareando as nossas práticas.

Os desafios também aumentam porque são mais questionamentos, mais dúvidas, essa coisa da evolução eu acho q também areja um pouco. Eu acho que é bem a proposta desse grupo é essa.

E a proposta da pesquisa é efetivamente ver qual o efeito da reorganização nas crianças, assim em termos pedagógico, em termos de proposta curricular, quais são os avanços, as dificuldades, os retrocessos que ela causaria na pratica porque nos estamos falando de classes numerosas que é a realidade do nosso município hoje. eu acho que a gente tem que tentar outros caminhos porque os moldes que a gente tem hoje eles não são favoráveis né, a gente tem que buscar outros caminhos. Quando eu ouvi falar da proposta eu achei muito interessante, mas sozinha eu acho que realmente ia ser muito complicado.

e uma coisa que eu acho que a gente estava conversando outro dia foi essa questão de que algumas coisas já nos incomodavam pra que se buscasse a mudança. Não é?

Porque você colocou alguns itens dos moldes que existem, da prática cotidiana , que te incomodavam em relação a educação infantil né?

Quando você estava colocando a questão do tempo de espera não foi que você mencionou?

do tempo de espera, de todo mundo Ter que fazer a mesma coisa ao mesmo tempo né, de achar que todo mundo gosta de fazer a mesma coisa quando na verdade não é bem por ai, cada um tem seu interesse. 
$\mathrm{E}$ as vezes você percebe a criança, você percebe que a criança não está feliz né, as vezes a gente olha e vê q não está feliz daquele jeito. E acho q também é um espaço pra conviver e também pra Ter prazeres.

e você acha que da pra criança ser feliz dentro da escola? eu acho que sim e pra um professor? O professor também...risos.....espero que sim Antes tinha dias assim que eu ia pra casa e você sabe quando você vai achando q você fez tudo errado? Por isso que eu acho que quero passar por essa nova experiência . é aquela sensação de : dava pra ser diferente mas eu não sei como né, mas assim quem sabe, talvez seja um caminho ou seja uma aproximação ou seja mais um caminho que diz que ainda não é esse mas daqui dá pra aproveitar $\mathrm{X}$ elementos. Mas pelo menos eu to experimentando, to tentando outra coisa né , fazendo algumas coisa pra melhorar né, e acho assim no decorrer a gente vai melhorando mesmo. Nas trocas a gente vai aprendendo . Eu acho que a gente tem que estar sempre tentando, eu acho que essa é uma tentativa .

1 legal, muito obrigado. 


\section{ANEXO B - ANÁLISE DE CONTEÚDOS -ENTREVISTA DE 12/02/06 - PROFª LUCIANA}

\begin{tabular}{|c|c|c|c|}
\hline TEMAS & TIPO DE COMENTÁRIOS & & $\begin{array}{l}\text { Freqüência } \\
\text { de citações: }\end{array}$ \\
\hline \multirow{8}{*}{$\begin{array}{l}\text { Citações } \\
\text { quanto aos } \\
\text { materias } \\
\text { disponíveis }\end{array}$} & \multirow[t]{2}{*}{ A - volume de brinquedos } & A1 - visão positiva & 1 \\
\hline & & A2 - visão negativa & 3 \\
\hline & \multirow[t]{2}{*}{ B - variedade de brinquedos } & B1 - visão positiva & 1 \\
\hline & & B2 - visão negativa & 0 \\
\hline & $\begin{array}{l}\text { C - prioridade de jogos educativos em relação aos } \\
\text { jogos simbólicos }\end{array}$ & & 1 \\
\hline & $\begin{array}{l}\text { D - mudança ou novas idéias a partir da observação } \\
\text { dos materiais disponíveis }\end{array}$ & & 3 \\
\hline & $\begin{array}{l}\text { E - necessidade de intervir no manuseio de } \\
\text { materiais }\end{array}$ & & 2 \\
\hline & F - proposição de novos materiais & & 1 \\
\hline \multirow{2}{*}{$\begin{array}{l}\text { Citações } \\
\text { quanto ao } \\
\text { espaço } \\
\text { reorganizado }\end{array}$} & \multirow[t]{2}{*}{ G - visão quanto ao espaço reorganizado } & G1 -visão positiva & 1 \\
\hline & & G2 - visão negativa & 0 \\
\hline \multirow{8}{*}{$\begin{array}{l}\text { Citações } \\
\text { quanto as } \\
\text { práticas } \\
\text { anteriores e o } \\
\text { desafio da } \\
\text { proposta de } \\
\text { reorganizaçã } \\
\text { o }\end{array}$} & \multirow[t]{5}{*}{$\mathrm{H}$ - ansiedade frente ao novo } & H1 - espaço & 0 \\
\hline & & $\mathrm{H} 2$ - material & 1 \\
\hline & & H3 - proposta & 1 \\
\hline & & H4 - pesquisa & 3 \\
\hline & & H5 - grupo de professores & 1 \\
\hline & \multirow[t]{2}{*}{ I - visão positiva da proposta } & I1 - pelas crianças & 1 \\
\hline & & 12 - pela educadora & 3 \\
\hline & J - vontade de enfrentar desafios & & 4 \\
\hline
\end{tabular}




\begin{tabular}{|l|l|l|c|}
\hline $\begin{array}{l}\text { K - segurança pela possibilidade de troca com } \\
\text { parceiros }\end{array}$ & 4 \\
\hline $\begin{array}{l}\text { L questionamentos de práticas comuns no âmbito da } \\
\text { educação infantil da Prefeitura do Município de São } \\
\text { Paulo }\end{array}$ & $\begin{array}{l}\text { L1 - relacionado ao } \\
\text { metodo }\end{array}$ & 2 \\
\cline { 2 - 3 } $\begin{array}{l}\text { L2 - relacionado aos } \\
\text { resultados }\end{array}$ & 0 \\
\cline { 2 - 3 } $\begin{array}{l}\text { L3 - relacionado ao } \\
\text { sentimento da criança }\end{array}$ & 1 \\
\cline { 2 - 3 } & $\begin{array}{l}\text { L4- relacionado ao } \\
\text { sentimento da educadora }\end{array}$ & 2 \\
\cline { 2 - 3 } & $\begin{array}{l}\text { L5 - relacionado a sua } \\
\text { prática anterior }\end{array}$ & 5 \\
\hline
\end{tabular}


ANEXO C - FICHA DE OBSERVAÇÃO DO ENVOLVIMENTO DA CRIANÇA

EMEI EURÍPEDES SIMÕES DE PAULA- SÃO PAULO

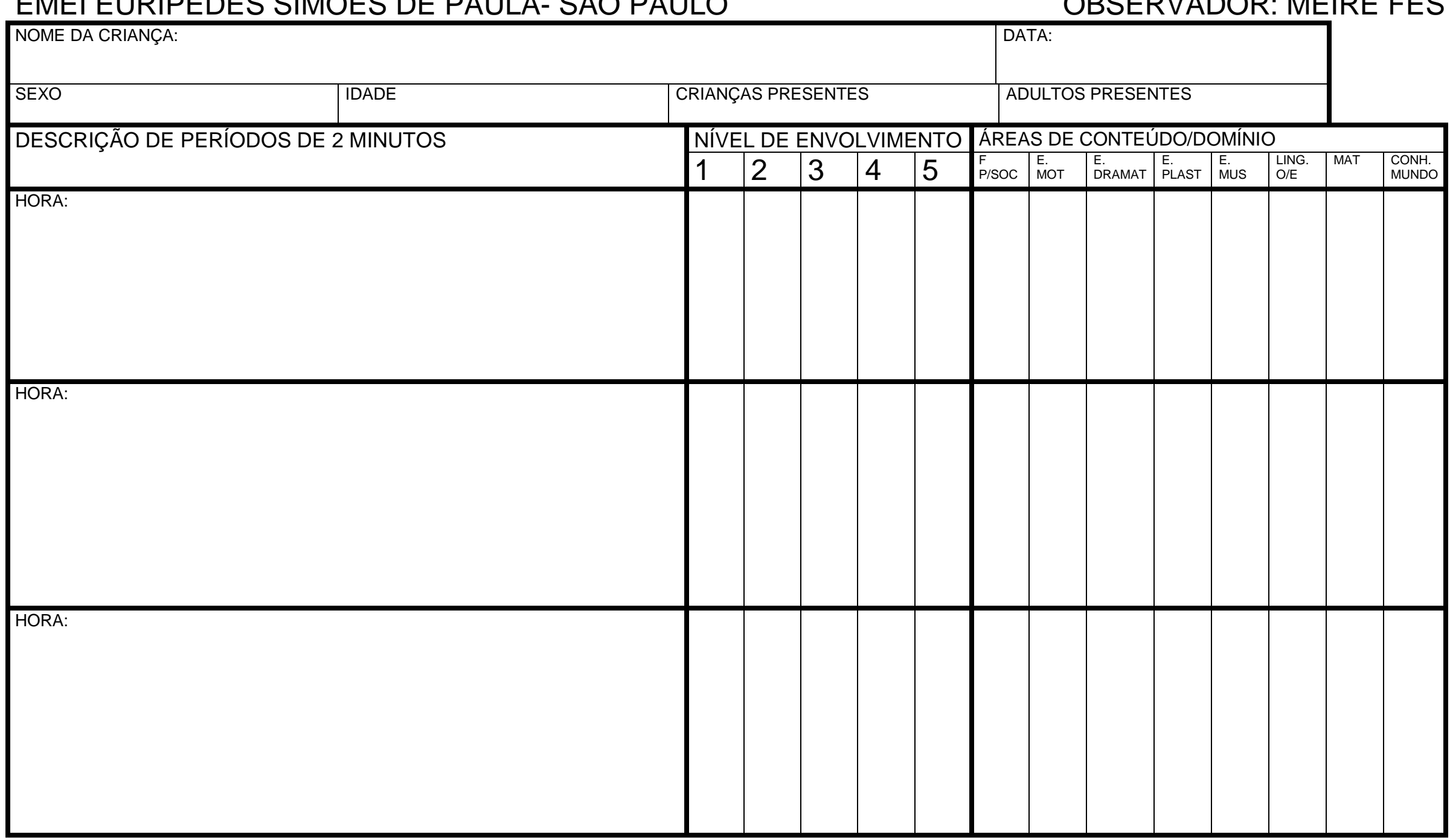





\section{ANEXO D - TRANSCRIÇÃO DA ENTREVISTA DE 20/12/06 \\ Entrevista com a educadora Luciana 20/12/06- 52 minutos}

As falas transcritas em negrito referem-se a educadora Luciana e as demais referem-se a pesquisadora.

Pesquisadora - hoje nós pretendemos fazer a avaliação de 3 coisas: do próprio projeto de reorganização, de como você viu esse projeto, da parceria na questão da pesquisa,e a avaliação desse processo de trabalho neste ano. Então o que você teria pra falar de pontos positivos, pontos negativos, de coisas que você gostou de que você não gostou, que você achou bom ou ruim, fácil ou difícil, dessa proposta de quando você entrou na escola, de reorganizar os espaços e as atividades.

- Luciana - acho que vou começar pelos pontos positivos, eu acho assim que no começo eu senti bastante dificuldade para me organizar, que é tudo aquilo que a gente vinha conversando, mas eu acho que isso não foi negativo, acho que foi até tranqüilo.

Acho que fazia parte do processo, era uma mudança e então eu sentir algumas dificuldades e ter dúvida em alguns momentos, isso era super tranqüilo. De ponto positivo: uma experiência super nova que pra mim foi muito interessante, eu já estava bastante insatisfeita com a forma com que eu vinha trabalhando antes e agora parece que embora eu não tenha conseguido um monte de coisas (eu acho que o ano que vem vai ser muito melhor, eu espero) mas eu estou no caminho, eu terminei esse ano com essa sensação .

- eu terminava sempre o ano assim: poxa vida, isso não foi legal, aquilo não foi legal mas esse ano eu sai com essa sensação de que eu estou no caminho, parece que isso que ficou pra mim.

- Para mim acho que foi isso, pras crianças em sala de aula essa questão da autonomia, de ver a alegria das crianças foi muito positivo. Eu tive crianças que tinham bastante dificuldade de adaptação, não só o Lucas mas o Lucas Vitor, o Riam, que tinha dificuldade quando chegou na escola, dificuldade de se aproximar das crianças para brincar .Então foi 
de uma forma tão tranqüila, tão gostosa pra eles a integração que depois eu os vi assim no final do ano super bem, super felizes .

- esses dias eu estava pensando, esse ano eu disse muitos sins pras crianças, pode tal coisa, pode tal coisa, eu posso fazer isso agora e isso é muito bom, principalmente quando se trata de estar trabalhando.... é muito gostoso quando você pode dizer muitos sins: você pode fazer tal coisa, pode isso.

- O fato deles terem oportunidade de decidirem pelo que querem fazer naquele determinado momento também foi bastante favorecedor .

- As vezes eu propunha alguma coisa em sala de aula, eles faziam aquela atividade naquele dia e nunca mais tinham oportunidade de experimentar aquilo, de explorar, aprofundar mais aquilo. Esse ano não, como você comentou das pinturas, favoreceu assim que eles experimentassem essas diferentes possibilidades mais de uma vez, explorassem mais isso por causa do ambiente mesmo. Eles iam usando técnicas que eles já tinham aprendido, explorando, criando coisas novas, ousando, fazendo até o que não tinha pedido porque eles tinham essa oportunidade, essa liberdade. Coisa que eu nunca tive antes, porque a gente tolhe isso.

- Eles nunca conseguiriam se fosse na minha sala de aula antes .Isso pra mim foi muito positivo.

- Acho que isso foi o que marcou mais mesmo. E pra mim também o fato de poder acompanhar as crianças mais de perto nas atividades até a forma de interferir em algumas situações.

Antes parece que era assim, era tudo no grupo, era (como vou explicar) era uniforme, parecia que tinha um padrão. E agora não, parece uma coisa mais individualizada em alguns momentos. Você consegue acompanhar algumas coisas, consegue interferir de alguma forma nas atividades.

- As vezes antes eu tinha a sensação de que as coisas eram daquele jeito e eu não ia conseguir mudar muitas coisas. E esse ano assim eu acho que você conseguiu trazer: "OLHA TAL COISA" "VOCÊ NÃO CONSEGUE MUDAR DETERMINADA COISA?" por pequenas que eram as mudanças, as vezes mudanças até curtas. 
- Quando pensava no barulho da sala por exemplo, as intervenções que a gente foi fazendo e você foi fazendo na prática nessa discussão dos pontos que a gente ia levantando. Então antes eu não pensava muito em possibilidades de mudança mas parece assim que o fato de ter você ali junto acompanhando, olhando também, isso também cria um novo olhar pra algumas coisas.

- Porque geralmente a gente está sempre sozinha na sala de aula.

- Esse isolamento é muito ruim ? essa sensação.

- então, porque as vezes você esta tão envolvida ali com a sala de aula, tão envolvida que não consegue ver outras coisas. $C$ não consegue perceber outras coisas, então acho que a pesquisa também veio colaborar com isso, em direcionar o meu olhar pra algumas coisas também.

- Você se sentiu pesquisadora nestes momentos? No sentido assim de tentar procurar motivos ou razões ou intervenções.

- Não, eu acho que esse tinha que ser o papel de todo professor, não deveria? Tinha que ser o papel do professor. Eu não me senti pesquisadora, eu me senti talvez mais professora. Porque as vezes eu não tinha mesmo esse olhar, pareciam que as coisas eram assim meio estanques, as vezes eu tinha essa sensação.

- As vezes eu pensava mas eu pensava sozinha as possibilidades de mudança. A gente fica muito sozinha, geralmente a gente não tem coordenador e quando tem ele não conhece a sua sala .

- E o fato de você conhecer a minha sala, conhecer os alunos, isso ajudou muito também para direcionar algumas coisas.

- Em algumas coisas as mudanças eram pequenas mas significativas. Eu acho que eu consegui muitas coisas, muitas outras ficaram a desejar ainda . Eu sempre termino com essa sensação, não tem jeito . Eu sempre acho que tenho que mudar um monte de coisas mas é sempre.

- Eu achei que esse ano eu não consegui direcionar, eu nunca tinha trabalhado dessa forma. Você ter um espaço pra conversar com as crianças, uma roda todos os dias, eu achei que eu devia ter proposto outras coisas, ter feito um monte de coisas de outras formas, mas acho que $o$ ano que vem vai ser melhor nesse sentido. 
- Sabe que quando eu ouço você falar assim: eu acho que isso ficou falhou ou alguma coisa assim, por mais que eu não concorde com o que você fala (que eu não concordo) eu acho que você tem essa coisa em você, de busca da qualidade constante. Está assim e o que eu posso fazer pra ir além disso. Então quando você fala; olha a minha roda está boa mas....eu quero que vá além disso.

- Tal intervenção que eu fiz teve sucesso mas o que eu posso ir além disso , essa busca da qualidade é meio que incessante na sua ação. Concorda com essa minha leitura da sua ação?

- É , mas me causa sempre essa sensação de não ter feito direito as coisas . O que mais que eu tinha pra dizer

- E de pontos negativos

- ai Meire , eu até tinha lido seu papel antes, eu fiquei pensando em pontos negativos, tendo em vista a nossa sala de aula, a nossa realidade, eu acho que é um trabalho super legal e tem coisas assim estruturais. Só se eu for pensar nisso, se tivesse um número menor de alunos, se tivesse uma sala de aula maior. Só se esses forem os pontos negativos

- mas assim da proposta em si eu não consegui levantar ponos negativos.

- Você tinha falado no começo do ano, numas entrevistas, que você achava que dessa maneira as crianças estavam rendendo um pouco menos, no sentido de aprender um pouco menos os conteúdos ou coisa assim, em comparação com os anos anteriores .

- Humhumm (sinal de concordância)

Daí, você acabou o ano com essa idéia ainda?

- não, eu até peguei o que eu estava usando como uma avaliação deles ( Porque a gente sempre fica preocupado com essa coisa da atividade, que eu acho que é também uma coisa que eu não consegui , que é me desprender da prioridade da atividade, minha prioridade é acompanhar a atividade e não a brincadeira, embora muitas vezes a gente tente se desdobrar, ou num dia falar assim vou acompanhar a brincadeira, Mas pra mim a prioridade ainda é a atividade. Ai quando eu fiz os relatórios eu retomei a de um terceiro estágio que eu tive a 2 anos atrás. 
- Com o mesmo número de alunos e eu vi que não, se for ver em termos de conhecimento, do que eu estava levando em consideração ali na avaliação, eu não terminei com essa sensação não

- Em termos de conteúdo você achou que está equiparado.

- Eu tinha essa sensação no começo, mas eu acho que não .eu acho que o fato de eu ter conseguido me organizar naquela questão de como falar, de como propor as atividades. Eu acho que a partir do meio do ano mais ou mesmo, com aqueles toques, que eram coisas que eu não estava conseguindo antes e tinha que dar a atividade quase que explicada individualmente.

- Acho que isso favoreceu um pouco. Acho que você vai aprendendo meio que no dia a dia, no trabalho

- No ensaio e erro a gente acaba

- Mas eu não sai com essa impressão não, eu acho que era assim uma coisa que eu tinha essa idéia mas que caiu por terra depois .

- Eu acho que a gente tem sempre essa perspectiva mais transmissiva né, de que eles vão aprender muito com a gente, da gente. E na hora que tem essa sensação de ; nossa, eu não vou estar tanto fornecendo os conteúdos , como ele vai aprender?

- Acho que é uma insegurança que a gente acaba tendo e acaba vendo que depois estes conteúdos vão permeando outras atividades também.

\section{E as salas são diferentes}

- e as vezes a gente esquece mesmo os objetivos da ed infantil, a gente fica tão preocupado com algumas questões e o fato deles terem tanta autonomia, deles experimentarem tantas coisas diferentes, isso pra gente pelo menos é o mais importante.

- Não sei como seria essa proposta no ensino fundamental mas aqui na ed infantil, pra gente é o caminho, é uma possibilidade muito boa .

- Você estava falando dos alunos, assim, dos 2 Lucas, do Riam. A questão da adaptação. Você imagina, por exemplo o trabalho que você fez com outras crianças, que você teve intervenções com todas e com alguns você precisou fazer intervenções mais pontuais e mais seguidas. Por exemplo o Rogério, o Gabriel, a Karen, dentro de um outro espaço de sala.

- Fico imaginando eles na primeira série 
- Como é que você acha que seria isso?

- Eu acho que seria muito difícil pra eles, ia ser. É como que se naquele momento onde eles pudessem escolher o que eles gostam de fazer, é como se naqueles momentos eles ficassem mais tranqüilos, não era naquele momento que eu precisava chamar atenção deles ou que aconteciam os problemas.

- Exceto da Karen, a Karen não conseguia mesmo sossegar.

- Mas acho que pra eles seria bem mais difícil. Mas acho que eles aprenderam de outra forma como se controlar, porque não é se eu tivesse mesas e cadeiras na sala de aula eles iam ter que aprender isso meio que forçados. Eles iam ter que ser forçados a isso .

- Seria pela coersão? Você ia ter que impor?

- la. E talvez eu ia dizer assim: ele é sempre inquieto, essa criança não para, eu talvez ia dizer isso. Mas eu consigo dizer: aqui na roda ele não consegue participar, mas na atividade ele consegue se concentrar, ele pega um material que tem interesse e fica não sei qto tempo com aquilo. Eu acho que isso eu fui percebendo com o tempo e também na atividade isso também teve resultados

- Se pegar a atividade do Rogério lá no começo do ano e pegar no final, teve resultados bastante satisfatórios e isso se refletiu nas atividades. Embora ele ainda

- você acha que esse conhecimento que você foi adquirindo das crianças. A que você atribuiria isso que você acabou de me falar: olha em tal atividade ele tem tal comportamento, em tal atividade ele tem outro comportamento. Aqui a concentração é maior, aqui tem mais dificuldade. Você acha que alguma coisa em você, ou na sua concepção ou na sua prática , alguma coisa mudou pra isso ou você acha que você sempre teve essa facilidade de observação ou sempre conseguiu identificar isso?

- Eu não sei, acho que agente se torna um pouco mais observador. Até assim porque algumas vezes você direcionava o meu olhar pra algumas coisas e eu espero que a partir do ano que vem eu consiga fazer isso sozinha. E era uma coisa assim que em anos anteriores eu não tinha essa exigência parece 
- Não tinha mesmo e esse ano foi um ano assim que parece que eu estava começando, que eu estava aprendendo a fazer. era como se nos anos anteriores dentro daquela proposta eu já sabia, mas algumas coisas ficavam muito falhas .

- Essa proposta exige mais observação?

- Exige muito mais eu acho, muito mais e até quando no final do ano quando eu tive mais a oportunidade de conversar com a mãe do Gabriel porque ela estava muito preocupada como seria a $1^{\text {a }}$ série dele. $\mathrm{E}$ ai eu comentava, não mas o Gabriel consegue fazer determinadas atividades muito bem, ele consegue ficar um tempão se ele escolhe por exemplo uma atividade, um jogo ou brincar no computador ele consegue permanecer um tempo muito grande naquilo. Ai ela ficou assim um pouco surpresa, me pareceu.

- Porque talvez em casa pra ele é sempre um menino inquieto também, ou ela estava levando em consideração quando ele brinca com os primos que moram no quintal e ele é sempre uma criança inquieta.

- É muito bom ver os 2 lados da criança, ver que em alguns momentos ele consegue determinadas coisas que eu acho que antes eu achava que não.

- Você acha que a criança tem consciência dessas conquistas?em algum momento algum demonstrou isso?

- Em algum momento algum deles te demonstrou ter consciência disso, de que ele está mais controlado?

- Acho que sim, estava lembrando daquelas construções gigantes que o Rogério fazia , ele gostava muito de mostrar aquilo, que ele conseguia .

- Eles demosntravam assim em alguns momentos que tinham conseguido alguma coisa assim nesse sentido de colocarem regras assim pras coisas que eles não tinham antes. Mas acho que isso não cabe aqui.

- Tipo o Gabriel, igual aquele dia, ele sabia que pra ele falar, todo mundo tinha que ficar quieto, mas ele não conseguia ficar quieto.

- Ele não conseguia se controlar mas estava começando a ter consciência da regra 
- ele estava tendo consciência da regra . O Rogério muitas vezes interferia na brincadeira dos outros mas ele tinha consciência de que quando era ele que tinha montado la a casinha, ele era o dono da brincadeira e as pessoas tinham que respeita-lo .Eles tinham mais consciência disso, principalmente quando favorece né.(risos)

- mas o Rogério tinha bastante admiração pelas coisas que ele fazia

- acho que as crianças mostravam várias coisas que faziam com prazer, com entusiasmo .

- Com orgulho de ter feito?

- É com orgulho, sem muita ...

- No dia da árvore de natal, que eu fiquei colocando o que eles tinham feito de diferente, ai já não caba mais na porta e eles vieram: "poxa vida, mas por que? Ainda tem pra colocar, você não vai colocar tudo? “

- Então eles gostavam muito disso, tudo que eles faziam eles sabiam que era aceito.

- Você acha que isso afetava a auto- estima deles?

- Isso é sempre positivo, saber que o que você faz é aceito, é admirado pelo grupo.

- Por exemplo, tem criança que :"Não, mas eu não quero ficar lá pra cantar" (referindo-se ao dia que foi instituído na escola para cantar o hino nacional) e daí assim ; "não, tem coisas que é possível e tem outras que não são" "mas eu não quero ficar lá agora". Então, eles tinham liberdade pra falar o que eles queriam e não queriam e até se manifestar de uma forma sutil, porque é dizendo o que quer e o que não quer .

- Quando se tem essa liberdade de dizer é muito bom, porque você não precisa se manifestar de outra forma

- Nesse trajeto de 1 ano de novidade pra você , de novidade pra eles, você foi fazendo alguns balanços das coisas que aconteceram. Uma coisa que você mudaria de imediato na sua prática em 2007, que você falasse assim: isso eu mudaria ou isso eu já mudei em comparação com a minha prática em 2005 e eu acho que isso não tem volta. Você acha que teve algum reflexo na sua concepção de criança ou na sua concepção de trabalho pedagógico ou alguma coisa que você fala: isso eu posso dizer que teve uma alteração radical ou mais definitiva assim. Teve alguma coisa que você fale isso? 
- É que você fala assim em 2007 eu quero continuar, e acha que vai acontecer outras coisas. Você está dando uma proposta de continuidade. Agora, se você pensar sua prática anterior, em 2006, uma coisa que você acha assim:isso é uma coisa que me marcou, ou que mudou. Tem alguma coisa ou não?

- Eu acho que sim, acho que você passa a olhar a criança de uma forma diferente.

- No que?

- Eu acho que você passa a olhar, a acreditar que ela pode participar muito mais das atividades, de que ela não esta ali só pra... Ela está ali experimentando diferentes possibilidades, diferentes atividades.

- Você deixa de ser o centro das atenções e isso pra mim foi muito bom, eu nunca mais quero voltar a estar no centro das atenções e eu não sei se eu tivesse que voltar pra uma sala como era antes como seria.

- É lógico que você vai se adaptar a mesma coisa, mas eu acho que algumas coisas seriam diferentes, acho que eu não conseguiria voltar da mesma forma, pelo menos eu não sei dizer direitinho assim o que eu senti de mudança .

- Ai Pesquisadora eu não sei dizer assim de mudança efetiva

- Mas quando você fala pra mim: " eu podia até voltar pra uma sala com 10 mesinhas, cadeiras, mas não ia ser da mesma forma . é a sua prática que não ia ser da mesma forma?

- É

- É , você me falou: a minha prática não ia ser da mesma forma

- Eu acho que pra mim ia ser muito angustiante ate.

- O jeito de ver a criança não ia ser o mesmo?

- É eu acho que não

- Porque você me falou também que não ia achar que a média era o normal

- Hum Hum (concordância )

- São mudanças profundas não são? Embora você não as tenha nomeado

- EU acho que é diferente assim, me angustiava muito aquela questão de todo mundo fazer a mesma coisa na mesma hora, na quantidade que eu queria, era realmente uma pré-escola, estava preparando realmente pra 
primeira série mesmo e crianças muito pequenas, parece que não cabia eles ali.

- Se eu tivesse que voltar, ia ser diferente, pelo menos eu ia tenta fazer diferente. Mas eu não consigo nomear o que exatamente.

- Agora, a última coisa: a gente tentou olhar um pouco pra criança assim, do envolvimento dela nas atividades dando pra nós, enquanto pesquisadoras ali unidas nisso, o envolvimento dando alguns indícios de necessidade de intervenção. Então a gente olhava pra criança e através do envolvimento que ela estava demonstrando ou não ou através dos objetivos que se tinha pra aquela atividade.

- Eram 2 pólos que foram fazendo algumas intervenções. Você acha que esse envolvimento das crianças, do início do ano, pro final do ano,do grupo como um todo. Você acha que teve alteração? Pra melhor, pra pior ou não teve?

- Você falou pra mim, olha; as produções mudaram

- As produções mudaram, e daí assim eu estava olhando uma coisa assim bem básica, no começo do ano o computador por exemplo você tinha que ficar ali prestando atençõ o tempo todo em quem estava mudando . Porque eles nem conseguiam mexer muito porque rapidinho já estava mudando . depois eu achei que o barulho da sala aumentou bastante mas o envolvimento da sala também aumentou de certa forma.

- As crianças permaneciam mais tempo em determinada atividade, você não precisava ir la toda hora ficar prestando atenção em quem estava no computador porque eram 2 crianças que estavam no computador mais os outros estavam envolvidos em outras coisas e nem estava exigindo ali fossem mesmo para o computador

- Eu acho assim, eles foram ...é como se eles tivesssem mesmmo assim, eu escolhi determinada atividade e hj eu vou fazer isso. E realmente o envolvimento naquela atividade ia aumentando e parece qeles iam assim aprofundando mais naquela atividade (algumas coisas, em alguns momentos )

- Nem todo eu observei isso, mas parece que pra alguns, cada vez eles iam se aprofundando mais naquela atividade, então a brincadeira as vezes ia se tornando mais interessante, a forma de construir a casinha por exemplo ia ficando mais legal 
- Com mais detalhes.

- Mas ainda com barulho

- Sabe que isso era uma coisa que me incomodava: o fato de você ficar incomodada .Você falava assim pra mim: "'olha o barulho me incomoda mais quando você esta aqui do que quando você não está".

- Essa era uma fala que você tinha. E eu ficava incomodada não com o barulho, mas com essa fala sua no sentido de que até que ponto você não estava tendo essa visão de supervisão, de avaliação, que naão era o que estava acontecendo

- Não era o que estava acontecendo, então assim ; Foi complicado pra você essa parceria? No que?

- Não.

- É realmente quando você estava eu prestava mais atenção em algumas coisa que estavam erradas mas assim eu não achei que quando você estava eu me policiava em algumas coisas, não. Pra mim era normal mas eu achava assim; ah, como ela está filmando o barulho parece que esta muito alto.

- Mas uma vez por semana eu achava tão tranqüilo assim, pra mim não tinha nada. Pelo menos eu tentava agir assim como se faz todo dia, era a mesma coisa que todos os dias.

- E era uma coisa que eu achava legal também pelo fato de ter com quem trocar, de ter com quem comentar. Embora em algumas coisas eu me senti incomodada né, mas era só com o barulho, não era com outras coisas não.

- E eu acho que essa, e agora eu to falando enquanto professora e pesquisadora ao mesmo tempo, essa necessidade de troca a gente sempre tem na rede, essa proposta de parceria que está vindo dessa pesquisa e de ter parceiros ali na situação, na vivência, de 2 olhares pra mesma coisa.

- Muda muito

- Não importa que olhares

- E assim, sempre que acontecia alguma coisa você falava assim e se for de outro jeito? Coisa que eu não ia pensar sozinha, coisa que não teria a 
mesma visão sozinha. E é muito interessante na rede, que grande problema é que até o coordenador tem medo de entrar na sala de aula .

- Não sei qual o problemas mas ele parece que tem medo de entrar na sala de aula .alguns professores não gostam e nunca o coordenador vai na sua sala, então ocoordenador nunca sabe .

- Nem conhece seus alunos

- Ele sabe assim do que você conta, do que você esta vendo e ele só consegue dar uma opinião em cima do que você esta falando, ele nunca nem viu .foi no pátio muito raramente, conversou as vezes com a criança mas eles tem muita, a gente tem muita restrição quanto a isso.

- Sabe de uma coisa, eu quero ver se você acha que essa minha opinião é pertinente ou não.sabe de uma coisa que eu percebi, alem dessa sua busca de qualidade que eu acho uma coisa fantástica e que é difícil a gente ver, os bons profissionais tem isso, mas é difícil a gente ver isso no geral .

- No geral, quando aquilo está bom, eu sempre fiz assim eu não preciso pensar sobre isso ,mas além disso que era uma coisa que eu ahcava muito legal em você, eu comecei a achar, com o passar do tempo, eu comecei a prestar mais atenção na atenção que você estava dando. No seu olhar mais atento pras situações.

- Então você fala que tinha coisas que eu falava pra você mas você esquecia que tinha muitas coisas que você falava pra mim tipo; ah essa semana o fulano fez tal coisa e daí teve como conseqüência a brincadeira $\mathrm{Xe} Y$ ou ontem a Natali estava brincando de não sei do que..... Você acha que seu olhar sofreu alguma transformação? O seu olhar, independente da parceria, independente da pesquisa.

- Humm hummm(concordância)

- Qual?

- Eu acho que eu conheço mais as crianças, eu posso dizer muito mais a respeito deles do que eu diria de outras crianças que já permaneceram 1 ano comigo isso é uma coisa que indica. Eu sei muito mais o que eles gostam, as preferências . numa atividade livre o que eles escolhem, quais as opções deles, até quando eu ia propor alguma atividade eu sabia quem eu ia precisar ajudar, quem ia precisar . 
- Era até legal porque eu sabia que tinha 3, 4 crianças e iam ter um pouco mais de dificuldade pra fazer aquela atividade por exemplo,eu chamava junto, eu acho que isso é muito mais interessante

- Era coisa que assim antes eu não conseguia interferir, eu não conseguia estar junto, eu acho que nesse sentido sim

- Eu tenho essa sensação também, que isso, essa disponibilidade sua de voltar seu olhar pra eles deu muitos avanços pra eles e foi reforçando essa prática legal que você tinha quando você fala, eu perguntei se você se sentia pesquisadora ou não, nesse sentido

- Porque eu via você como pesquisadora, olhando com olhar da pesquisa nesse sentido: como é que eu vou trabalhar regras com o fulano, eu preciso da Beatriz longe do Jefferson na hora da roda.

- É como se você fizesse assim pequenos estudos de caso, o caso Beatriz e ||Jefferson esta dando problema em $X$ situação mas na situação $Y$ eles brincam bem junto, etc.... Então neste momento eu preciso intervir e naquele outro eu posso deixar rolar.

- Eu percebia isso em diferentes situações, com diferentes crianças, que a sua intervenção ia .

- Mas isso é da função do professor

- É, mas é normal acontecer? É rotina isso acontecer?

- Não

- Pensa na nossa rede, isso é a rotina?]

- Então quando você falava pra mim (eu tenho até isso gravado) eu tenho que fazer alguma coisa porque eles pintam e depois pintam tudo de preto

- Humm hummm(concordância)

- Então você falava pra mim, eu tenho um problema e tenho alguma interveção

- Que cabe ai

- Que tem que caber. QUE daí vamos pensar qual é, mas sabe, esse olhar

- E esse olhar, a própria proposta favorece porque em outros anos eles pintavam 1 x na semana, uma vez a cada sei lá qto tempo, 1 desenho só e pronto, era 1 folha só.

- Geralmente meio que do jeito que gente tinha pedido 
- Então, hj só com guache, daqui 15 dias com plasticor. Então eram coisas assim que você nem tinha oportunidade de observar. Era uma coisa que as vezes nem ia se repetir ficava muito vago.você não conseguia nem observar determinadas coisas

- Então agora eu quero fazer uma pergunta chave , é a última. Fala pra mim uma coisa que você fala: eu não sabia isso sobre crianças e eu acho que eu descobri esse ano

- ai Meire que difícil.

- Eu lembro que no começo do ano, acho que na primeira vez que a gente conversou, que a gente estava lá na sala e eu fiquei assim admirada com a quantidade de materiasi que havia na sala . Eu achava que eles nem iam conseguir se organizar com aquilo, hj eu acho assim que tem pouco, que poderia ter bem mais

- Eu acho que eu menosprezava um pouco essa capacidade deles até de conseguir se organizar, de conseguri sei lá, mesmo assim de trabalhar num ambiente que tem tantas possibilidades, escolher.

- Eu tinha uma idéia meio diferente quanto a isso, não sei seé algo assim que eu descobri. Eu achava assim , é tanta coisa...se um vai fazer uma coisa e o outro vai fazer outra coisa completamente diferente, será que vai dar pra se organizar?

- Pra mim não era tão trabalhoso assim, embora você comente comigo que na hora de reorganizar você só assista ( referindo-se ao comentário sobre a realidade da pesquisadora em sala de aula como educadora) e eu participava, mas eu sempre participei e antes eu achava que tinha que participar muito mais até, então acho que isso era uma coisa que eu achava que eles não iam conseguir e eles conseguem muito bem .

- O que mais? Ai Meire acho que é isso.

- Está ótimo, quer falar mais alguma coisa?

- Não

- Ah então está ótimo, obrigado. 


\section{ANEXO E - AUTO-RELATOS DA EDUCADORA LUCIANA ( EXCERTOS)}

\section{7 de Fevereiro}

Iniciamos ontem o trabalho com computador. As crianças ficaram super entusiasmadas e todos queriam brincar. Por enquanto sou eu que orienta a troca, mas daqui uns dias pretendo conversar com eles sobre alguma forma para que se organizem sozinhos.

A maioria das crianças, por nunca ter usado o computador, está aprendendo a usar o mouse.

Observo que durante as atividades em sala, falam um pouco alto, não por não estarem envolvidos com a atividade, mas por vezes, por estarem animados.

\section{3 de marco de 2006}

Como nesta semana só teve aula na quinta e sexta, a sala estava com número pequeno de alunos,hoje apenas 15.

$\mathrm{Na}$ hora do parque estava chovendo, sugeri que fizéssemos pintura e todos quiseram fazer a mesma atividade. Nunca tinha permitido que uma mesma criança fizesse várias pinturas como hoje.

Algumas crianças utilizaram apenas uma folha, enquanto outras, 4 ou 5 folhas. Foi bem legal observar o interesse e o envolvimento deles e permitir que pintasse, quanto quisessem, sem muitas restrições, como eu me via obrigada a fazer antes, por uma questão de "ordem" , tempo...

\section{Julho}

Até meados de junho eu chamava as crianças por grupos para fazer a atividade proposta no dia, no entanto alguns reclamavam que queriam fazer a atividade com determinado colega ou que queria, naquele momento, brincar no computador. 
Então conversei com eles e disse que não ia mais chamá-los desta forma e que eles decidiriam em que momento iriam fazer a atividade, mas que ninguém poderia recusar-se a ir quando a última turma fosse chamada, independente da atividade que estivessem fazendo.

Acho que essa foi a melhor forma de organizá-los, raramente se recusam a fazer a atividade quando é necessário chamá-los.

O fato de não ter que esperar um grupo inteiro terminar pra chamar o grupo seguinte também tem sido um ponto positivo. 